CELSO DE BARROS GOMES

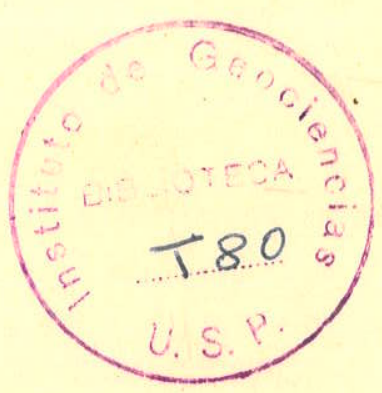

\title{
PETROLOGIA DO MACIÇO ALCALINO DE ITAPIRAPUÃ, SP
}

\author{
DEDALUS - Acervo - IGC

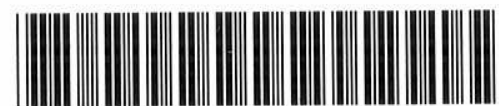 \\ 30900008486
}

TESE DE DOUTORAMENTO APRESENTADA A CADEIRA DE PETROLOGIA DA FACULDADE DE FILOSOFIA, CIÊNCIAS E LETRAS DA UNIVERSIDADE DE SÃO PAULO 
IN DICE

INTRODUÇĀO

GEOLOGIA

Aspectos gerais

Rochas vizinhas do corpo alcalino

Adamellito - Granodiorito

Calcários

Diabásios

MINERA LOGIA

Introdução

Metodologia

Feldspatóides

Nefelina

Cancrinita

20

Agregado

20

Sodalita

Feldspatos

Feldspato alcalino

Piroxênios

Soda - augita

Egirina - augita

Egirina.

Granadas

Outros minerais acidentais

Biotita

Wollastonita

Pectolita

Fluorita

Eucolita

Pirita

Pirrotita

Calcita

Mineral A

Mineral B

Minerais acessórios e de alteração

Magnetita 
Sequência de cristalização

Feldspatóides

PETROGRAFIA

Introdução

Metodologia

Nefelina sienitos

Melanita - nefelina sienitos

Biotita melteigito

Melanita malignito

Variedades enriquecidas

Wollastonita-melanita-nefelina sienito 68

Cancrinita mariupolito $\quad 70$

Pulaskito $\quad 73$

Tinguaítos

Carbonatitos

Brecha magmática

Introdução

Distribuição dos elementos

Silício e Oxigênio

Alumínio e Gálio

Titânio

Magnésio e Ferro

Vanádio

Crômio

Níquel e Cobalto

Escândio

Itrio

Cálcio e Estrôncio

Potássio e Bário

Sódio

Zircônio

Nióbio

Lantânio

Cobre

Berílio 
PETROGENESE

Cristalização fracionada

A natureza do material primário

Formação dos carbonatitos

Formação do corpo de magnetita.

Fenitização

Análise comparativa com ocorrências congểneres

Ocorrências brasileiras

Ocorrências estrangeiras

CONCLUSOES

AGRADECIMENTOS

BIB LIOGRAFIA 


\section{INT RODUÇÃ}

O distrito alcalino de Itapir apuã situa-se na região sul do Estado de São Paulo (coordenadas geográficas aproximadas: latude $24^{\circ} 40^{\circ} \mathrm{S}$ e longitude $49^{\circ} 15^{\circ} \mathrm{W} . \mathrm{G}_{\bullet}$ ) e seu acesso é feito pela cída de de Itapeva, da qual dista aproximadamente 130 quilômetros (Fig.1). Seu reconhecimento geológico deu-se em 1958, em decorrência dos tra balhos realizados na região pelo engenheiro José Epitácio Passos Gui marães, do Instituto Geográfico e Geológỉco do Estado de São Paulo. com o propósito de estudar uma ocorrência de magnetita localizada nas imediações da barra do rio Itapir apuã. Em agôsto de 1959, sob a supervisão do cittado engenheiro, a Companhia de Cimento Portland Maringá, com sede na cidade de Itapeva, SP, procedeu à exécução do primeiro programa de pesquisa na área, consistindo no levantamento magnetométrico e trabalhos de perfuração, complementados pela abertura de vários poços e trincheiras. As primeiras amostras com que nos dispusemos a inciciar èste estudo foram coletadas pelo enge nheiro José Epitácio Passos Guimarães, que as colocou à nossa dis. posição.

Nossa primeira visita ao local da ocorrểncia reali. zou-se em novembro de 1963, em companhia do Prof. Geraldo C. Mel cher e sra., geólog Brigitte S. Melcher, e teve por objetivo cole tar amostras de carbonatitos, dadas como existentes no interior do corpo alcalino (Passos Guimarães, 1960). Por sugestão do Prof. Rui Ribeiro Franco, ex-diretor do Departamento de Mineralogia e Petrología da. Faculdade de Filosofia. Ciências e Letras da Universidade de São Paulo, que vendo na variação litológica presente neste maciço e no caráter inédito de seu estudo, elementos suficientes para justifi. car a execução de uma pesquisa minuciosa na área, o autor deu iní cio, nos meses de janeiro e fevereiro de 1964, a um programa de re conheclmento geológico que levaria à elaboração de trabalho, princì palmente de natureza mineralógico-petrológica, a ser apresentado co mo assunto de sua futura Tese de Doutoramento junto à Cadeira de $\mathrm{Pe}$ trolog:a da referida Faculdade. Nos trabalhos de campo empreendi dos, contamos com a participação do sr. Carlos Rotta, então aluno do Curso de Geologia desta Faculdade, e valemo-nos, sobretudo, de 


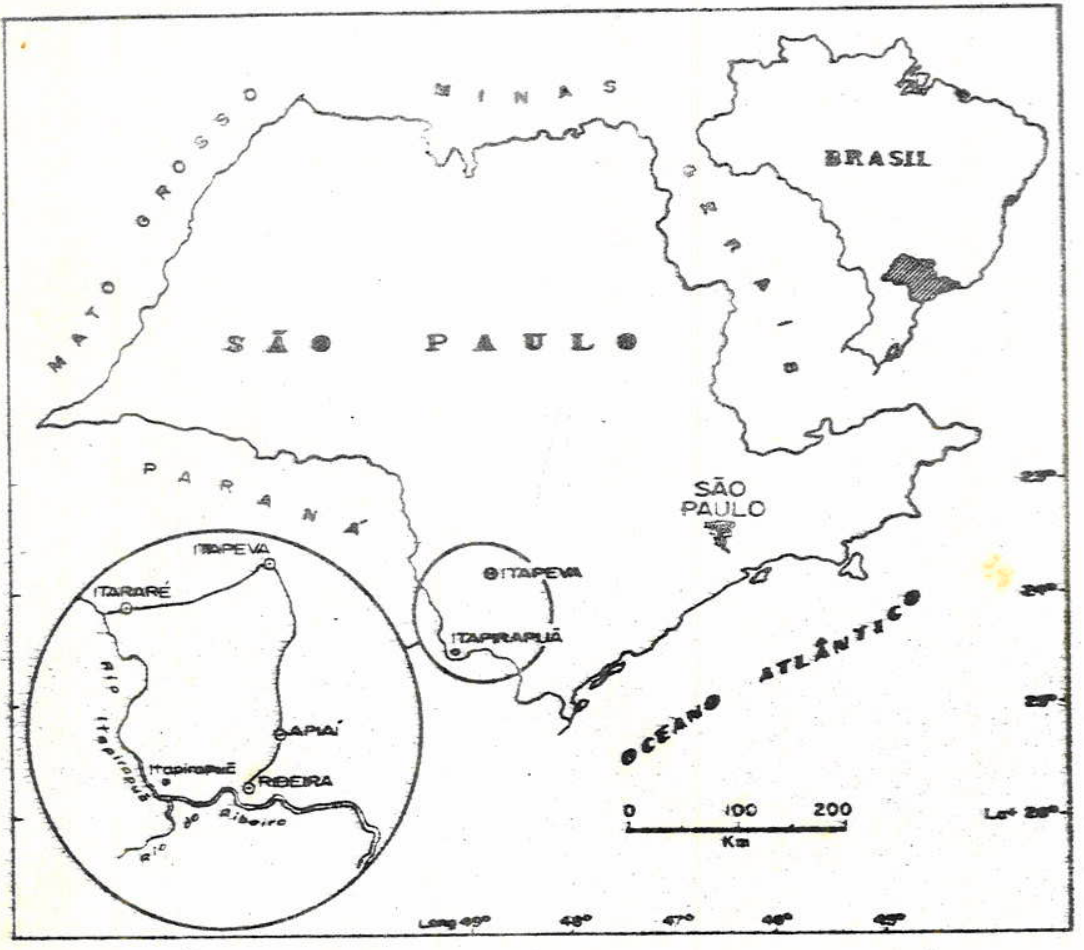

Fig. 1 - Asapo esquemótico indicando o localizaçōo do áreo imvestigoda. 
fotografias aéreas da regũão (Cruzeiro do Sul, vôo 1962) e fôlhas topográficas planimétricas, (PROSPEC, 1954), ambas na escala aproxima da de 1:25000. Contudo, face aos inúmeros obstáculos encontrados, re fletidos no relêvo fortemente acidentado da região, na ausência de meios de comunicação e na intensa cobertura vegetal ali existente, res tringimos nossas atividades à tarefa precípua de delimitação da área ocupada pelo corpo alcalino e de executar um programa de coleta sis. temática de amostras no seu interior, tendo para isso percorrido todos os leitos dos rios e córregos que drenam a área, com o propósito de caracterizá-lo petrogråficamente da forma maỉs completa possível.

A interpretação petrogenética do maciço alcalino de Itapirapuã constitui o objetivo primordial dêste trabalho. Para alcançá-la, procurou-se estudar o comportamento geoquímico das rochas e minerais da província, contando-se para isso com dados quími cos referentes aos elementos principais e aos elementos traços, bem como com as informações coligidas no decurso do traballho de levanta mento geológịco da região. Especial atenção foi dada aos constituin tes do grupo dos piroxênios e granadas, face à sua importância na evolução das rochas do maciço. Procurou-se também, do ponto de vị ta petrográfico, geológíco e químico, realizar breve estudo compara tivo entre esta província alcalina e outras congêneres. 


\title{
GEOLOGIA
}

\author{
Aspectios gerais
}

As rochas alcalinas afloram em área ocupada qua se totalmente por um batólito granítico que se estende para NE desde - Estado do Paraná até as proximidades da estrada que liga Itapeva a Apiaí (Fig. 2) e por metassedimentos, de idade provável précambriana., pertencentes a.o grupo Açungui. Na região, ësses metassedimen tos compőem-se predominantemente de filitos e muscovita xistos, com transiçöes para quartzitos e calcários, mais ou menos magnesianos , passando a calcoxistos. Em razåo de sua importância econômica, por serem as encaixantes dos minérios de chumbo e zinco, as rochas car bonácicas têm merecido especial atenção por parte da maioria dos pes quisadores que trabalharam na região. Como foge ao objetivo desta pesquisa estudo pormenorizado da geologia regional, evitamos aqui discorrer sôbre a longa série de trabalhos realizados nessa parte do vale do rio Ribeira e limitamo-nos, tão sômente, a tecer algumas considerações com base nos dados coligidos por Melcher e Johnson (1957) e, mais recentemente, por Melfi et al. (1965).

As feições mineralógicas e texturais dos metassedimentos regionais apontam o caráter epizonal do metamorfismo que os afetou, possibilitando assim enquadrá-los dentro da fácie dos xis tos verdes de Turner e Verhoogen (1960). Entretanto, rumando de oes te para este, verifica-se aumento progressivo do grau de metamorfis mo dessas rochás, culminando com o desaparecumento dos têrmos car bonáticos e transformação gradual das epimetamórficas, de natureza pelítica, em migmatitos e gnaisses (Melfi et al., 1965, p. 471). Do pon to de vista estrutural, verifica-se ainda, segundo êstes Autores, que a direção dominante dos planos de xistosidade das rochas metassedi. mentares é NE-SW, com mergulho variável, porém mais freqưente pa. ra NW。

Recortando indistintamente os tipos litológicos da região aparecem representantes de um magma básico (diabásios)na for ma de pequenos diques.

O maciço alcalino de Itapirapuã, de forma İregular e alongada para NW, Localiza-se nas imediações da barra do rio que 


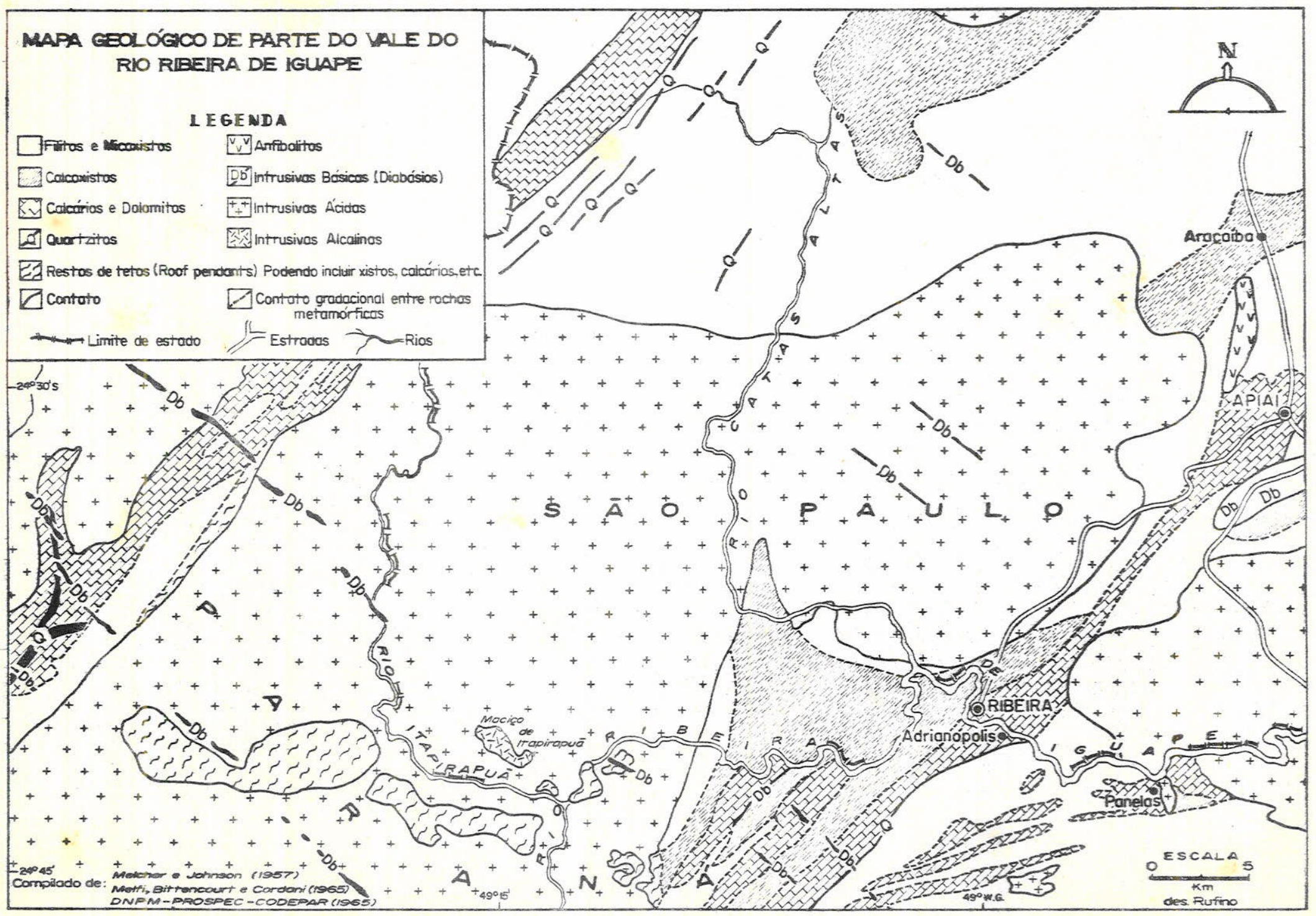

Fig. 2-Mapo geológico regional simplificado. 
The empresta o nome, ocupando área aproximada de 4 quilómetros qua drados (Fig. 3). Do ponto de vista petrográfico, compõe-se êle exclusivamente de rochas insaturadas, sendo o tipo litológico dominante, ne felina sienitos, portadores ou não de granadas titaniferas (variedade melanita)。Rochas alcalinas básicas, representadas por biotita meltei gito e melanita malignitos, constituem juntamente com wollastonita - melanita-nefelina sienito, pulaskito e cancrinica mariupolito (têrmos petrográficos enriquecídos, respectivamente, em cálcio, potássio e sódio), as rochas de menor distrỉbuição geográfica dentro da provín cia. Tinguaitos estão presentes no interior e fora do maciço, tendo mesmo sido encontrados a vários quilômetros de distância do corpo. Ocorrem, provàvelmente, na forma de pequenos diques verticais, di.. rigidos para NW e de espessura decimétrica. Carbonatitos, na forma de veios irregulares, de alguns centimetros de largura e cortando nitidamente os nefelina sienitos, ocorrem na parte central do corpo rochoso, enquanto que uma zona de brecha magmática, associada princi palmente aos nefelina sienitos de granulação fina a média, aflora na sua parte sul, cobrindo área de algumas dezenas de metros quadra. dos. Um corpo de minérío de ferro constituído de magnetita granular e ḋiomórfica está presente na extremidade sul do maç̧ço e vem sen. do objeto de exploração comercial por parte da Companhia de Cimento Portiand Maringá (Fotos 1 e 2). Sua forma, em profundidade, se gundo Passos Guimarães (1960), lembra a figura de uma cornucópia com eixo voltado para SW. Os dados coligidos por êste Autor, em programa de pesquisa na área, permitiram inferir para êsse corpo, reservas de minério de ferro da ordem de 215.700 toneladas.

O estudo geocronológico do maciço, pelo método potássionargổio, foi realizado por Gomes e Cordani (1965), tendo sim do executadas datações em quatro varjedades litológicas do distrito, admitidas como representantes de fases diferentes no seu curso de evolução petrogenética. As rochas selecionadas foram: um biotita mel teigito, dois nefelina sienitos e um tinguaito, respectivamente, amos tras 1, 12, 14 e 19 da Fig. 4. O biotita melteigito teve sua idade de terminada em biotita; o tinguaíto em rocha total, dada a impossibili. dade de separação dos seus constituintes minerais, e os nefelina sie. nitos em feldspato alcalino e piroxênio.

Corn exceção da idade do pirroxênio da amostra 14 


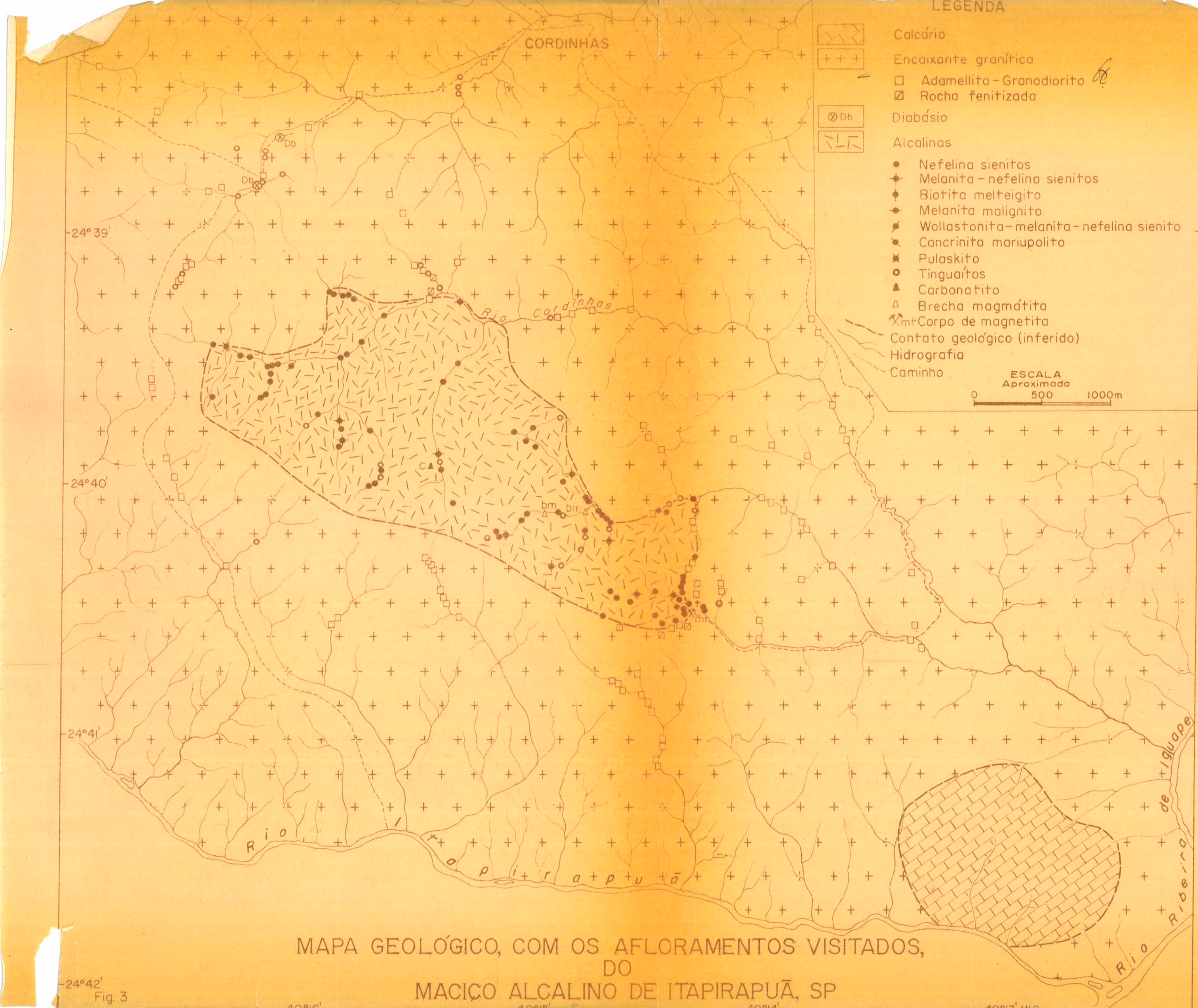




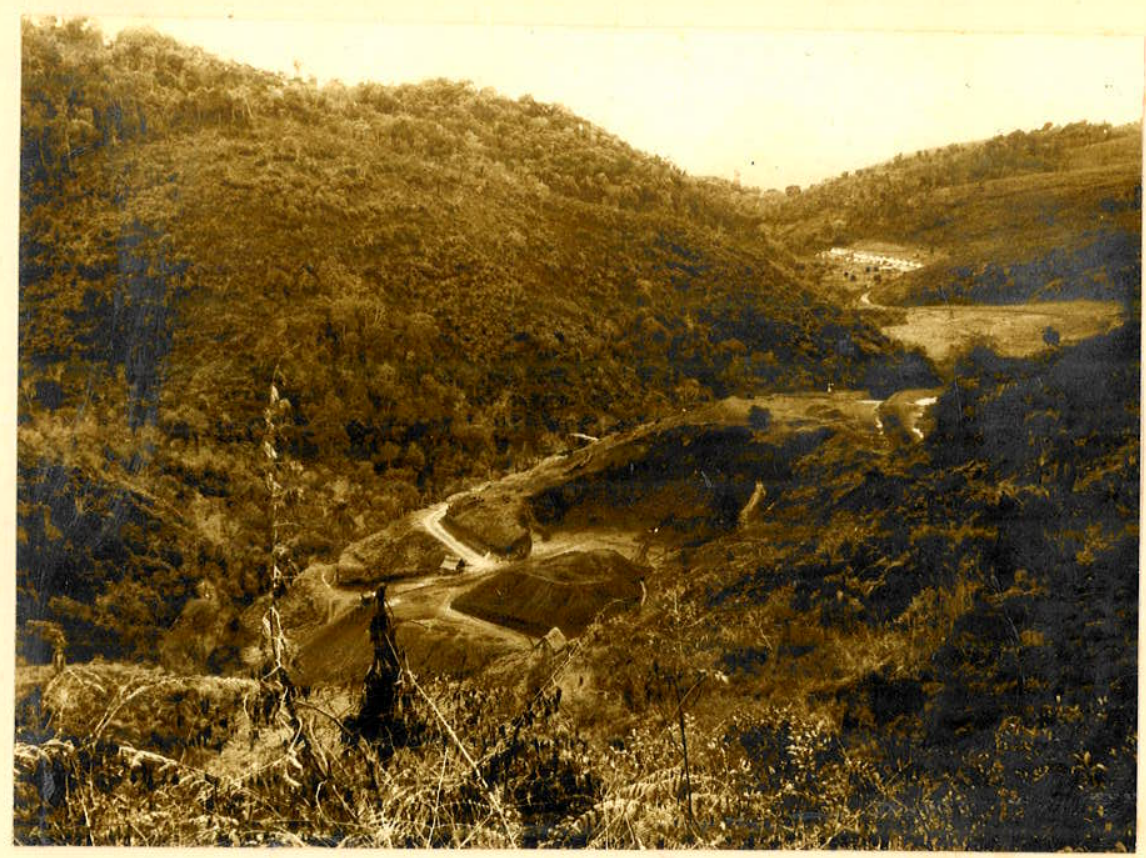

Foto 1 - Vista geral mostrando a jazida de magnetita de Itapirapuã. Ao fundo a vila operária.

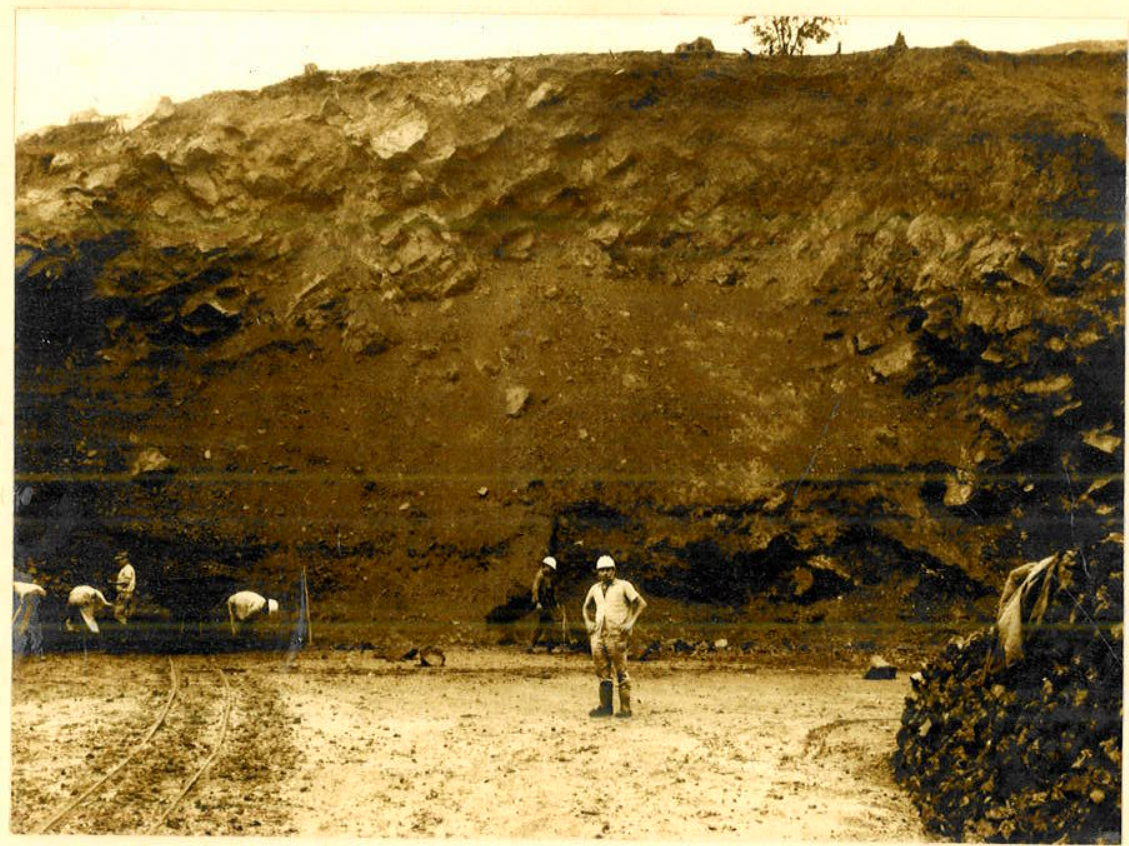

Foto 2 - Vista parcial mostrando uma das frentes de trabalho. 


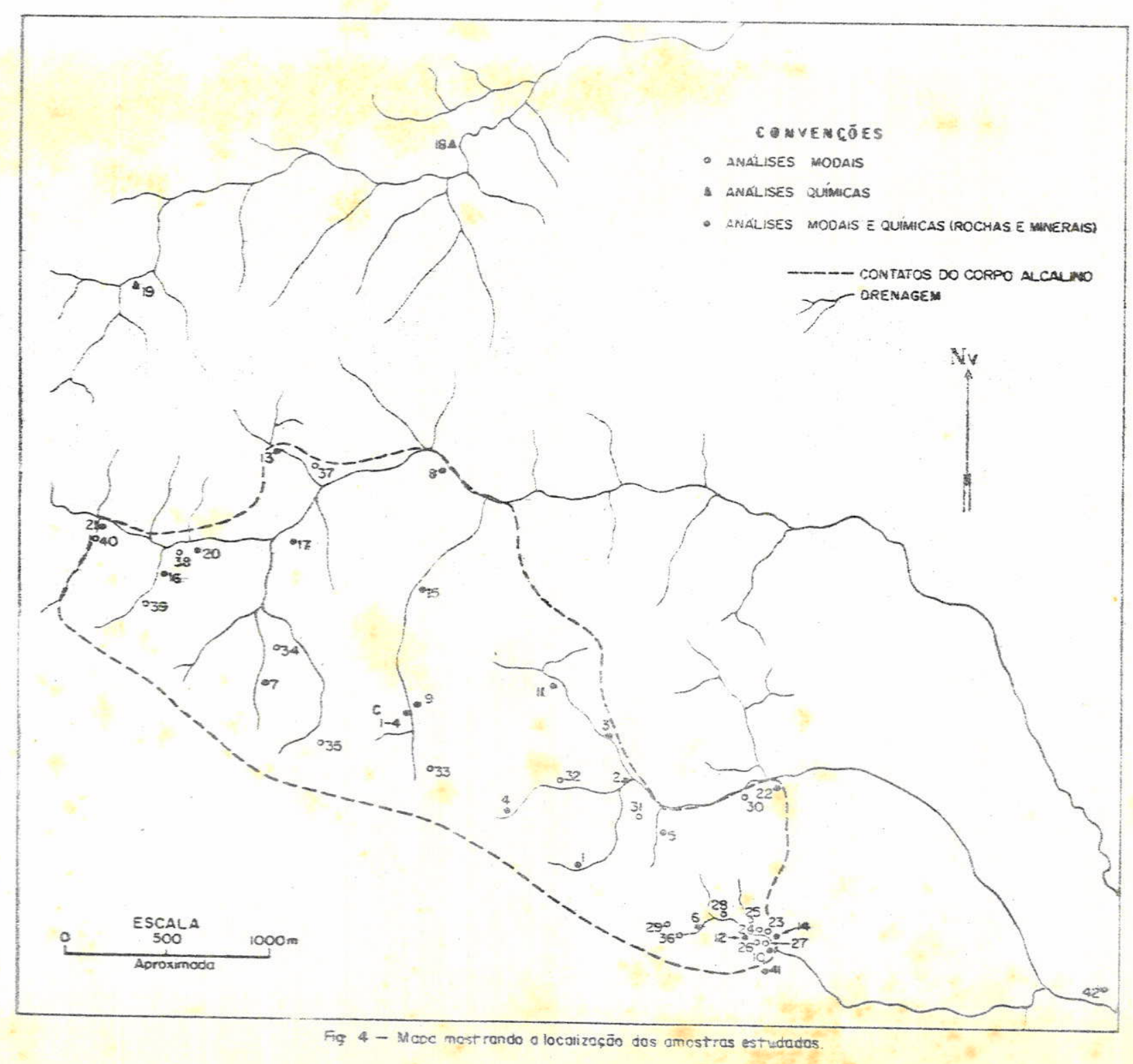


(164 milhões de anos), tida como anômala por Gomes e Cordani.(1965), tôdas as outras rochas apresentaram valores essencialmente concor dantes, admitido o êrro analítico, dando j.dade média de 104 millhões de anos, permitindo com isto incluir esta província, dentro da escala de tempo geológico (Kulp, 1961), no Cretáceo superior.

Dentro do quadro cronológico das rochas alcalinas do Brasil (Amaral et al., 1967), o maciço de Itapir apuã (cf. his togra ma da Fig. 5) ocupa posição singular e intermediária à dos dois gru . pos, cujas idades estão compreendidas nos intervalos de $51-82$ 122-136 milhões de anos, estabelecidos por êsses Autores.

$$
\text { Rochas vizinhas do corpo alcalino }
$$

Intrusivas ácidas, metassedimentos de composi. ção carbonática e intrusivas básicas constituem, em ordem de abun dância, as rochas que ocorrem nas imediações do corpo alcalino e que estão representadas no mapa geológico preliminar da Fig. 3.

\section{Adamellito-Granodiorito}

Uma extensa massa intrusiva de composição mine ralógica variável, passando de adamellito a granodiorito, constitui a encaixante do corpo alcalino. A forma dessa massa è irregular, alon. gada para NE e seus contatos, aparentemente, são discordantes da direção geral da xistosidade dos metassedimentos regionais (Melfi et al., 1965, p. 461). Localmente, pode mostrar foliação, evidenciada pe la isorientação, quer dos minerais ferromagnesianos, quer dos cris tais maiores de feldspatos potássicos; o reduzido número de medidas que se conseguiu obter tornou impraticável qualquer tentativa de esta belecer a tendência dessa feição estrutural. Quanto à textura, assemeIha-se consideràvelmente às rochas graníticas das circunvizinhanças da cidade de São Paulo, que receberam a denominação genérica de "gra nito Pirituba" por Moraes Rego (1933). Ela é holocristalina, "porfiróide", com os cristais maiores de microclínio atingindo dimensões centi métricas e massa fanerítica hipidiomórfica, de granulação média a grossa. Por vêzes, essas rochas exibem feições texturaỉs e mineraló. gicas, representadas pelo fraturamento dos grânulos e posterior preen 


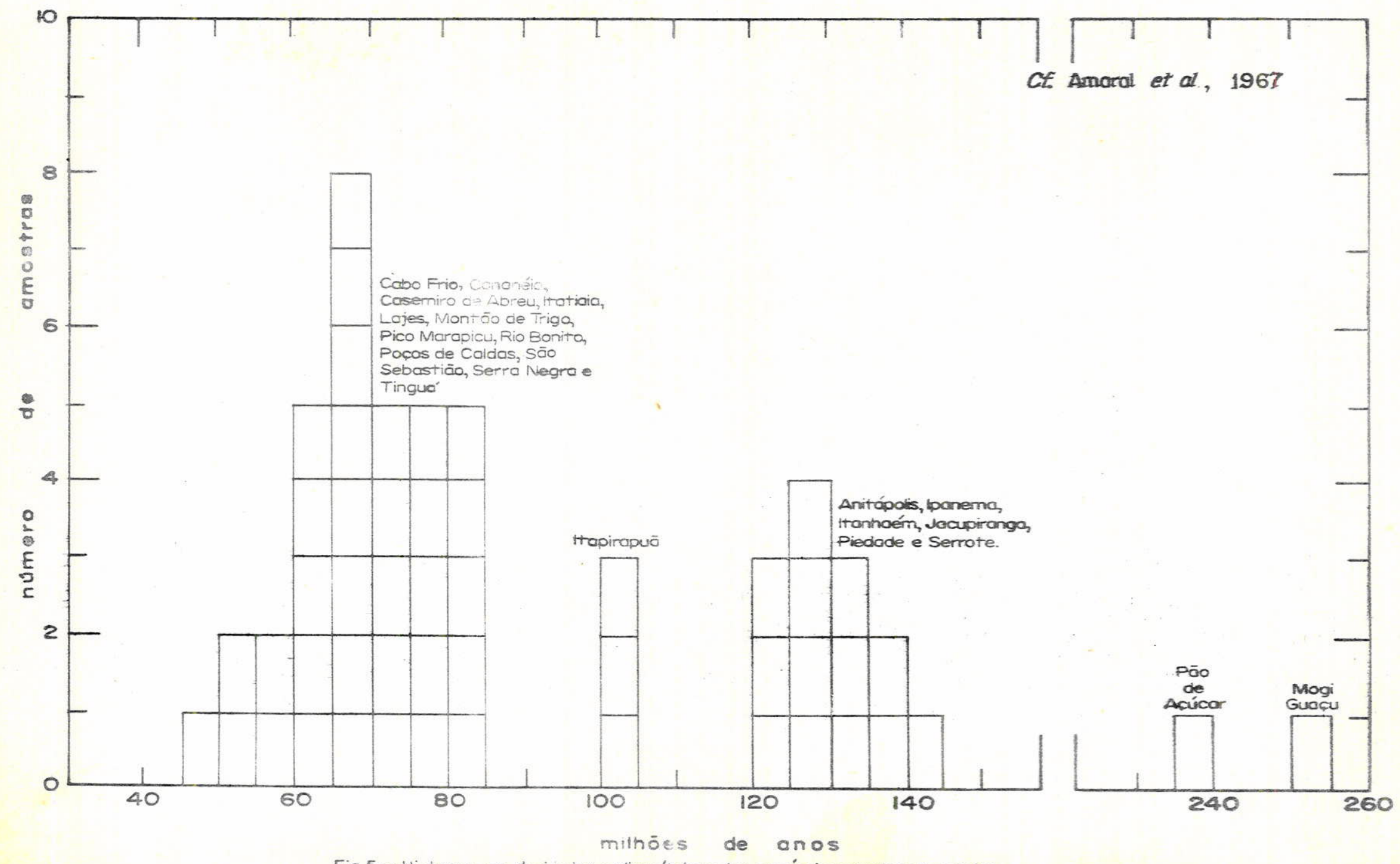

Fig. 5- Histogr as de ic des rodionétricos dos provincios aicolinas brasileircls. 
chimento dessas fraturas por minerais de formação secundária, indicativas de incipiente ação cataclástica, sendo tal fato observado mais intensamente na zona de contato com o corpo alcalino.

Os principais constituintes dessas rochas são: plagioclásio (albita a oligoclásio), microclínio, quartzo, biotita e horn blenda. Epídoto e clorita são os produtos de alter ação mais comuns dos minerais ferromagnesianos; contudo, não é rara a formação de epídoto às expensas dos feldspatos. Como minerais acessórios for am $\underline{i}$ dentificados: apatita, titanita, zircão, opacos (magnetita e pirita) e allanita. Estas rochas contêm, nas imediações do corpo alcalino, felds patos potássicos e álcali-cálcicos em proporçōes equivalentes, e consequtentemente, composição adamellítica de conformidade com a clas sificação petrográfica adotada por Williams et al. (1954, p.121).

Calcários

Um corpo de calcário compacto, de granulação mé dia a grossa, existente junto à barra do rio Itapirapuã, está represen tado na parte sul do mapa geológico da Fig. 3. Sua forma é ligeira mente alongada, com as dimensões máxima e mínima alcançando apro ximadamente $1,6 \mathrm{~km}$ e $1,2 \mathrm{~km}$ e encontra-se encaixado no maciço granítico, parecendo mesmo corresponder a um "roof pendant".Xenólitos similares de rochas calcárias, ou mesmo de calcoxistos, têm sido observados em outros pontos da região (Melcher e Johnson, 1957) e o mapa geológico regional da Fig. 2, na parte correspondente aoEs tado do Paraná, mostra idênticas estruturas a pequenas distâncias dó local em questão. Do ponto de vista mineralógico, êste calcário não apresenta qualquer particularidade especial, sendo constituído quase que exclusivamente de minerais carbonáticos (calcita) e opacos (pirit:a, hematita e mais raramente grafita) na forma de acessórios.

Na borda SW dêsse corpo foram encontrados blo cos irregulares, deslocados, de calcoxistos e muscovita xistos, re presentando provàvelmente pequenas intercalações de composição pe lítica dentro do pacote metassedimentar. 
doìs diques de diabásio, verticais, orientados próximo a N45W. Cons iituem pequenos corpos, com largura não superior a 2 metros e exten são de algumas dezenas de metros. Exibem textura subofítica, granulação variável de fina a média e composição mineralógica idếntica a dos numerosos diques encontrados em vários pontos da região por Mel. cher e Johnson (1957). Suas feições texturais e mineralógìcas guardam também total concordância com as características gerais dos diabá sios existentes no sul. do Brasil e que vem sendo objeto de estudos por parte de diversos pesquisadores nacionajs. Plagioclásio, de composio ção labradorítica e piroxénios (augita e mais subordinadamente pigeo nita) são seus minerais essenciais, aparecendo apatita, opacos (mag netita e ilmenita, por vêzes, intercrescidos) como principais acessó rios. Hornblenda comum e clorita, como produtos de alteração dos piroxenios, são frequentes, ocupando as partes marginais e preenchen do zonas de fraturas dêsses minerais. 


\section{MINERA LOGIA}

Int rod ção

As características mineralógicas das rochas alcalinas de Itapirapuã, refletindo em traços gerais defịciência em sílica e excesso em sódio, potássio e cálcio, guardam sensíveis semelhan ças com as de províncias congêneres mundiais e, de modo particular, com as ocorrências de Magnet Cove e Iron Hill, respectivamente, nos Estados de Arkansas e Colorado, Estados Unidos da América e de Iivaara, no distrito de Kuusamo na Finlândia.

A observação dos histogramas de composição mi neralógica da Fig. 6, construídos a partir de 38 análises modais de rochas do distrito (Tabelas Ia e Ib), indica que feldspatóides, incluin do os produtos de alter ação da nefelina, constituem, ao lado dos felds patos, os principais minerais félsicos, enquanto que os diversos mem bros da série dos piroxênios formam, juntamente com as granadas. os ferromagnesianos mais importantes. Dêsse total analisado, verifi ca-se também que feldspatos e piroxênios.sòmente não for am encon trados em duas variedades petrográficas (representação no histogra ma em hachuras), respectivamente, amostras 1 e 33 da Fig。4。A pri meir a correspondendo ao biotita melteigito e a segunda a um sienito trazendo cancrinita em lugar de nefelina e contendo biotita como prin cipal mineral máfico. Observa-se ainda, no histograma competente que uma das rochas estudadas, o pulaskito (Am。 21 da Fig. 4), apresenta em sua composição mais de $80 \%$ de feldspatos. O primeiro histograma das granadas (Fig。6) elaborado em escala idêntica à dos de mais, tem na classe modal $0-10 \%$, aproximadamente $87 \%$ das a mo tras analisadas. Já o segundo, com nôvo intervalo de distribuição pa ra as classes, mostra claramente que quase $40 \%$ das rochas estuda das não contém granada na moda (representação no histograma em ha churas).

Como minerais acidentais dessas rochas serão des critos, ao lado dos piroxênios e granadas citados acima e, entre ou tros, biotita, wollastonita e pectolita. Informações sôbre os acessó rios e acidentais serão fornecidas, sempre que possível, com a máxima quantidade de pormenores a fim de caracterizá-los do ponto de 

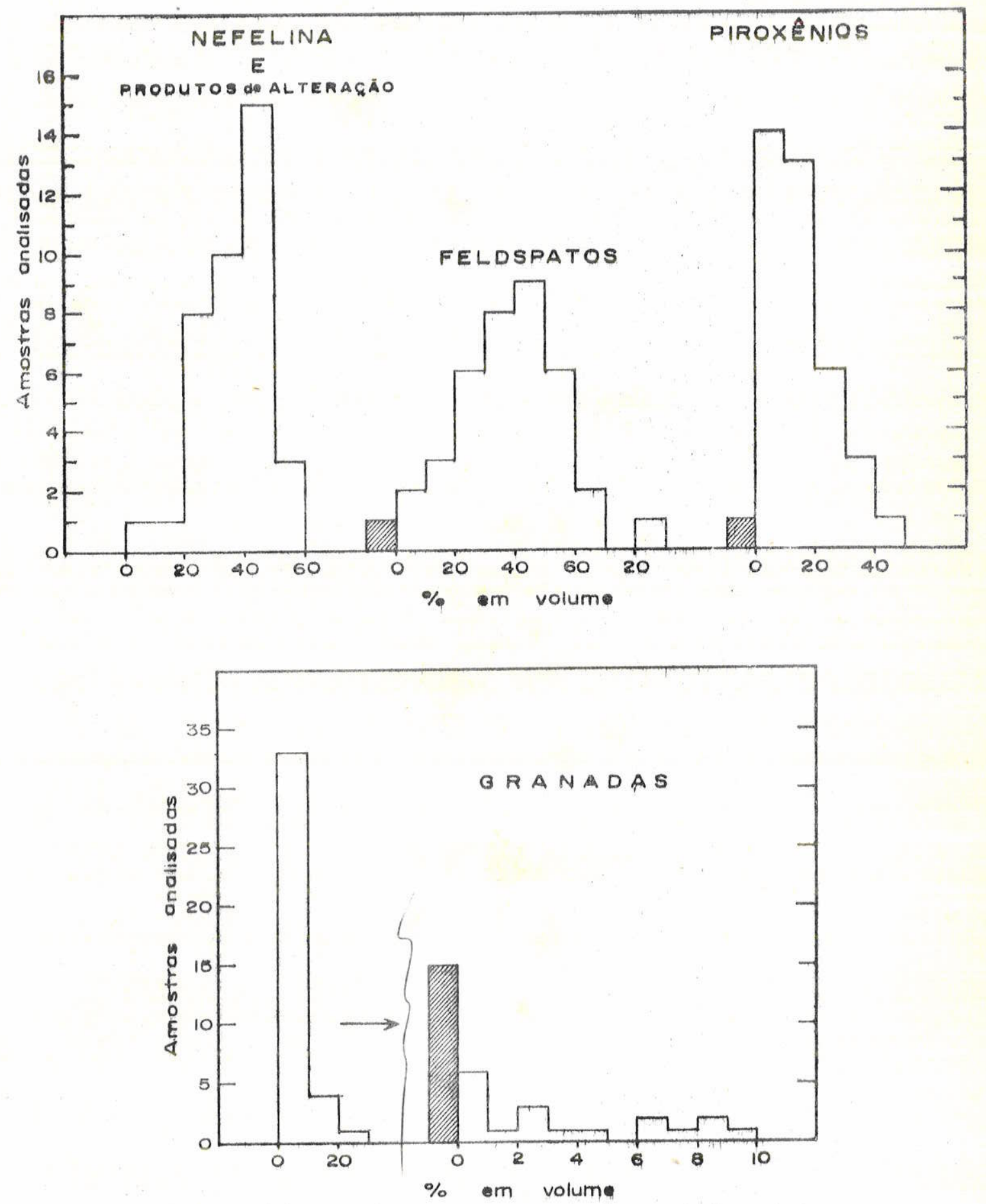

Fig. - Histogramas de composiçāo mineradógica (represæritaçőo om hachuras para amostras desprovidas do correspondent mineral). 
TABELA Ia

Análises modais

Biotita
Melteigito
Malignita

Melanita-nefelina sienitos

Nefelina sienitos

\begin{tabular}{|c|c|c|c|c|c|c|c|c|c|c|c|c|c|c|c|c|c|c|}
\hline & 1 & 2 & 3 & 4 & 5 & 6 & 7 & 8 & 9 & 25 & 34 & 10 & 11 & 12 & 13 & 14 & 15 & 16 \\
\hline $\begin{array}{l}\text { Feldspato } \\
\text { alcalino }\end{array}$ & - & 5,8 & 47,4 & 25,6 & 14,2 & 18,5 & 29,9 & 26,6 & 39,9 & 38,5 & 15,3 & 33,4 & 50,6 & 47,8 & 40,9 & 54,3 & 64,5 & 43,3 \\
\hline Albita $\left(A n_{0-5}\right)$ & - & - & - & - & $\operatorname{tr}$ & $\mathrm{tr}$ & 0,1 & - & - & - & - & - & - & 0,1 & 10,2 & - & - & 7,0 \\
\hline Nefelina & 23,5 & 34,7 & 2,8 & 8,6 & 25,6 & 25,5 & 42,6 & 20,6 & 35,3 & 43,2 & 33,5 & 11,6 & 28,5 & 17,2 & 13,0 & 33,0 & 20,1 & 20,8 \\
\hline Agregado & 9,4 & 6,4 & 15,9 & 26,5 & 17,5 & 19,4 & 5,1 & - & - & - & 7,6 & 2,8 & 2,4 & 5,7 & 0,4 & 0,5 & - & - \\
\hline Cancrinita & 2,5 & $\mathrm{tr}$ & 4,4 & 2,1 & 6,3 & 8,7 & 0,8 & 13,0 & 1,1 & 1,1 & $\operatorname{tr}$ & 14,6 & 12,2 & 21,7 & 9,7 & 2,6 & 5,5 & 8,1 \\
\hline Piroxênio & 46,1 & 31,0 & 3,2 & 19,2 & 25,4 & 18,3 & 13,3 & 17,6 & 11,9 & 9,4 & 30,3 & 31,9 & 3,5 & 6,3 & 24,1 & 5,2 & 7,2 & 19,1 \\
\hline Melanita & 0,3 & 14,9 & 22,6 & 15,1 & 8,3 & 7,1 & 6,0 & 14,4 & 8,5 & 6,8 & 9,4 & - & 2,5 & 0,4 & - & 4,3 & 2,0 & - \\
\hline Titanita & 5,4 & 4,6 & - & 0,6 & 0,7 & 1,8 & 0,1 & 1,8 & 1,5 & 0.6 & $-2,4$ & 0,5 & 0,1 & 0,2 & 0,2 & 0,1 & 0,5 & 1,3 \\
\hline Magnetita & 3,6 & - & - & - & - & - & - & - & 1,2 & - & 0,3 & $\mathrm{tr}$ & - & 0,5 & - & - & - & 0,1 \\
\hline Apatita & 2,2 & 1,4 & - & 1,8 & 0,8 & 0,4 & 0,5 & 0,5 & 0,6 & 0,4 & 1,1 & $\mathrm{tr}$ & - & $\mathrm{tr}$ & $\operatorname{tr}$ & - & $\operatorname{tr}$ & 0,1 \\
\hline Calcita & - & - & 1,4 & 0,5 & 0,2 & 0,2 & 1,6 & 5,2 & - & - & - & 0,2 & 0,2 & 0,1 & - & - & 0,2 & - \\
\hline Biotita & 7,0 & - & - & - & - & $\mathrm{tr}$ & - & - & - & - & $\mathrm{tr}$ & 0,7 & - & $\operatorname{tr}$ & - & - & - & - \\
\hline Pectolita & - & - & - & - & 0,7 & - & - & - & - & - & - & 4,3 & - & - & - & - & - & - \\
\hline Fluorita & - & - & - & - & - & - & - & - & - & - & - & - & - & - & - & - & - & 0,1 \\
\hline Sericita & - & - & - & & - & - & - & - & - & - & - & - & - & - & - & - & - & - \\
\hline Clorita & - & - & - & - & - & - & - & - & - & - & - & - & - & - & - & - & - & - \\
\hline Zeólitas & - & - & 2,2 & - & - & - & & - & - & - & 0,1 & - & - & - & - & - & - & - \\
\hline Mineral A & - & - & - & - & - & 0,1 & - & - & - & - & - & - & - & $\operatorname{tr}$ & 1,3 & - & - & 0,1 \\
\hline Mineral B & - & - & - & - & - & - & . & - & - & - & - & - & - & - & - & - & - & - \\
\hline Mineral C & - & 1,4 & - & - & 0,3 & - & - & - & - & - & - & - & - & - & - & - & - & - \\
\hline Eucolita & - & - & - & - & - & - & - & - & - & - & tr & - & - & - & 0,2 & - & - & - \\
\hline $\begin{array}{l}\text { Feldspatos: } \\
\text { Feldspatóides }\end{array}$ & $0: 100$ & $14: 86$ & $65: 35$ & $41: 59$ & $22: 78$ & $26: 74$ & $38: 62$ & $44: 56$ & $52: 48$ & $46: 54$ & $27: 73$ & $54: 46$ & $54: 46$ & $51: 49$ & $69: 31$ & $60: 40$ & $72: 28$ & $63: 37$ \\
\hline $\begin{array}{l}\text { Félsicos: } \\
\text { Máficos }\end{array}$ & $35: 65$ & $47: 53$ & $73: 27$ & $63: 37$ & $64: 36$ & $72: 28$ & $78: 22$ & $60: 40$ & $76: 24$ & $84: 16$ & $56: 44$ & $62: 38$ & $94: 6$ & $92: 8$ & $74: 26$ & $90: 10$ & $90: 10$ & $79: 21$ \\
\hline
\end{tabular}


TABELA Ib

Análises modais

Nefelina sienitos

\begin{tabular}{|c|c|c|c|c|c|c|c|c|c|c|c|c|c|c|c|c|c|}
\hline & 17 & 23 & 24 & 26 & 27 & 28 & 29 & 30 & 31 & 32 & 33 & 35 & 36 & 37 & 38 & 39 & 40 \\
\hline $\begin{array}{l}\text { Feldspato } \\
\text { alcalizo }\end{array}$ & 37,3 & 47,1 & 59,0 & 20,4 & 64,6 & 49,0 & 47,2 & 49,2 & 30.2 & 45,7 & 55,3 & 37.9 & 37,0 & 35,8 & 50,4 & 27,2 & 22,6 \\
\hline Albita $\left(\mathrm{An}_{0-5}\right)$ & 8,6 & $\operatorname{tr}$ & 0,2 & $\mathrm{tr}$ & $\operatorname{tr}$ & - & tr & 0,1 & - & - & - & $\cdot$ & $\mathrm{tr}$ & 5,4 & 0,5 & $\mathrm{tr}$ & - \\
\hline Nefelina & 21,8 & 34,69 & 18,3 & 43,6 & 15,2 & 22,4 & 37,7 & 36,1 & 30,5 & 40,3 & - & 10,7 & 37,7 & 25,7 & 19,0 & 53,2 & 21,3 \\
\hline Agregado & - & 1,5 & 8,1 & 2,0 & 2,5 & 3,7 & 0,9 & 1,2 & 0,7 & 0,2 & 0.4 & 7,1 & 0,7 & 0,4 & - & - & - \\
\hline Cancrinita & 9,6 & 4,4 & 7,8 & 3,8 & 6,3 & 13,7 & 4,9 & 6,2 & 9,1 & 0,7 & 28,9 & 28,7 & 7,2 & 11,0 & 0,8 & $\operatorname{tr}$ & 1,9 \\
\hline Piroxênio & 20,9 & 10,9 & 5,9 & 28,5 & 9,2 & 9,1 & 7,3 & 4,0 & 25,8 & 11,1 & - & 8,3 & 14,9 & 18,7 & 29,1 & 13,6 & 19,2 \\
\hline Melanita & - & - & - & 0,2 & - & 0,1 & 0,1 & 2,0 & tr & 1,7 & - & - & - & - & - & - & - \\
\hline Titanita & 1,3 & - & $\operatorname{tr}$ & 1,0 & $\operatorname{tr}$ & 0,8 & $t r$ & 0,4 & 2,6 & 0,2 & - & 0,8 & 1,4 & 0,5 & 0,1 & 1,7 & 2,9 \\
\hline Magnetita & - & 0,1 & 0,5 & - & 1,8 & 0,5 & - & - & - & 0,1 & 1.0 & 1,7 & - & - & $\operatorname{tr}$ & 0,2 & 2,2 \\
\hline Apatita & 0,1 & $\operatorname{tr}$ & tr & 0,2 & $\mathrm{tr}$ & - & $t r$ & - & 0,1 & tr & - & - & 0,1 & 0,2 & - & 0.1 & 0.9 \\
\hline Calcita & - & 1,3 & 0,2 & - & 0,4 & - & - & - & 0.2 & - & 8,4 & 2,0 & - & tr & - & 0,8 & 8,1 \\
\hline Biotita & - & $\mathrm{tr}$ & - & - & tr & tr & - & - & - & - & 6,0 & 2,8 & - & tr & - & 3,2 & 6,0 \\
\hline Pectolita & - & - & - & - & - & - & - & - & - & - & - & - & - & - & - & - & - \\
\hline Fluorita & 0,1 & tr & - & - & - & 0,2 & tr & - & $\mathrm{tr}$ & - & - & - & 0,1 & tr & - & - & - \\
\hline Sericita & - & - & - & - & - & - & - & - & - & - & - & - & - & - & - & - & - \\
\hline Clerita & - & - & - & - & - & - & - & - & - & - & - & - & - & - & - & - & - \\
\hline Zeólitas & - & - & - & - & - & 0,1 & - & - & - & - & - & - & - & - & - & - & 14,9 \\
\hline Mineral A & - & - & - & 0,3 & - & 0,4 & 1,9 & 0,8 & 0,8 & - & - & - & 0.9 & 2,3 & - & - & - \\
\hline Mineral B & - & 0,1 & - & - & - & - & - & - & - & - & - & - & - & - & - & - & - \\
\hline Mineral C & 0,3 & - & - & - & - & - & - & - & - & - & - & - & - & - & - & $=$ & - \\
\hline Eucolita & - & - & - & - & - & - & - & - & - & - & - & - & - & - & - & - & - \\
\hline $\begin{array}{l}\text { Feldspatos: } \\
\text { Feld spatóides }\end{array}$ & $59: 41$ & $54: 46$ & $63: 37$ & $29: 71$ & $73: 27$ & $55: 45$ & $52: 48$ & $53: 47$ & $44: 56$ & $53: 47$ & $65: 35$ & $45: 55$ & $45: 55$ & $53: 47$ & $71: 29$ & $34: 66$ & $43: 57$ \\
\hline Félsicos: & $77: 23$ & $88: 12$ & $93: 7$ & $70: 30$ & $89: 11$ & $89: 11$ & $91: 9$ & $93: 7$ & $71: 29$ & $87: 13$ & $85: 15$ & $84: 16$ & $83: 17$ & $78: 22$ & $71: 29$ & $80: 20$ & $61: 39$ \\
\hline
\end{tabular}


vista mineralógico。

Metodologia

Processos de separação, visando obter concentrados minerais de alta pureza para as análises químicas, consistiram da utilização do separador eletromagnético, aparêlho modêlo Frantz, e solução de Clerici. Esta foi empregada principalmente na separação de piroxênios e granadas. Na separação eletromagnética, as amostras de minerais foram trabalhadas preferencialmente na fração 0, 088-0,053mm (peneiras: 170-270 "mesh") e sòmente duas delas, correspondendo aos piroxênios $16 \mathrm{a}$ e $13 \mathrm{a}$, necessitaram maior redução da granulação(fração: 0, 053-0,043mm; peneiras: 270-325 "mesh") a fim de que se obti vesse total liberação dos grânulos. Maior rendimento na separação dos constituintes félsicos e máficos foi obtido com o aparêlho funcionando nas seguintes condições: intensidade de corrente de $0,45 \mathrm{~A}$, inclinação lateral de $22^{\circ}$ e frontal de $20^{\circ}$.

As granadas tiveram seus pesos específicos determinados pelo método do picnômetro, usando-se a técnica descrita por Holmes (1920, p.29) e picnômetro de 10 cc de capacidade.

Os índices de refração foram obtidos pelo método de imersão, utilizando-se fonte de luz de sódio para piroxênios, grana das e feldspatos e de luz branca para os demais constituintes minerais. Os valores conseguidos estão sujeitos a erros da ordem de $\pm 0,002$ para os minerais de índice inferior a 1,80 e de $\pm 0,005$, quando superior. A-s: birrefringências, quando fornecidas, for am calculadas diretamente a partir dos índices de refração. Os ângulos entre os eixos ópticos for am medidos numa platina universal de 4 eixos, marca Leitz, o mesmo sucedendo com os ângulos de máxima extinção inclinada dos piroxê nios. Estes foram sempre determinados em cristais geminados com o auxilio da técnica preconizada por Turner (1942, pp.571-583), estiman do-se a precisão dessas medidas em ${ }_{-}^{+} 1^{\circ}$. Os resultados fornecidos pa ra o $2 \mathrm{~V}$ dos minerais foram obtidos diretamente na platina ou por meio de projeção em diagrama de Schmidt, dependendo apenas do valor dêsses ângulos. A precisão dessas determinações pode ser tomada, em li.nhas gerais, como sendo da ordem de $\pm 2^{\circ}$.

Os minerais carbonáticos dos carbonatitos foram identificados por meio de ensaios químicos ("sténing") segundo o tra - 
tamento proposto por Warne (1962).

Os parâmetros da cela unitária das granadas foram calculados pelo Prof. José Vicente Valarelli, da Cadeira de Mineralogia da Faculdade de Filosofia, Ciências e Letras da Universidade de São Paulo, usando o método analítico por êle idealizado (Gomes et al. , em preparação) e que se baseia em dados do retículo recíproco. Cada $a_{0}$ obtido representa a média ponderada dos valores fornecidos em cada raja do diagrama, tendo como fator de ponderação os índices mile rianos. Foram calculados também, os erros médios da média pondera da, que afetam os parâmetros. A precisão das medidas é de $\pm 0,002$.

As fórmulas químicas dos piroxênios, expressas na base de 6 átomos de oxigênio, foram computadas, segundo Hess(1949, p. 625) e as normas moleculares de acôrdo com o sistema CIPW(con densado em Johannsen, 1939, I, pp.83-99). A relação atômica $\mathrm{Na}$ +K: $\mathrm{Mg}$ : Fe foi determinada de conformidade com o método proposto por Carmichael (1962, p.93) e, subseqtentemente, modificado por Aoki (1964, p.1210). Para o seu cálculo, $\mathrm{Na}$ foi combinado com $\mathrm{Fe}^{3+}$ visan do formar a molécula de Ac (acmita), enquanto que o $\mathrm{Na}$ destinado ao Al para a composição da molécula de Jd (jadeíta), foi excluído. Ao últỉmo têrmo da relação, $\mathrm{Fe}$, corresponde a soma de $\mathrm{Fe}^{2+}+\mathrm{Mn}+$ $\left(\mathrm{Fe}^{3+}\right)$, em que $\mathrm{Fe}^{3+}$ constitui o excesso, se existente, de ferro triva lente sôbre $\mathrm{Na}+\mathrm{K}$.

As fórmulas químicas das granadas, expressas na base de 24 átomos de oxigênio, foram calculadas segundo as sugestões propostas por Deer et al.(1963, I, pp.91-92), que considera que Ti substitui $\mathrm{Fe}^{3+}$, e conseqtenteme nte, ocupa o grupo $\mathrm{R}_{2} \mathrm{O}_{3}$ dêsses mine rais. Al, como é usual na estrutura de silicatos, foi distribuído entre o grupo $\mathrm{R}_{2} \mathrm{O}_{3}$ e $\mathrm{RO}_{2}$ e, sòmente em duas amostras, $\underline{20 \mathrm{~b}}$ e $\underline{39 \mathrm{~b}}$, mos tra-se insuficiente, completando com Si o valor teórico de 6,00 átomos por fórmula unitária da posição Z. Nestes dois casos, Ti foi interpretado como substituto de ambos, $\mathrm{Fe}^{3+}$ e Si. Para o cálculo das porcentagens moleculares dos componentes da série, procurou-se, fa ce às dificuldades resultantes do conhecimento inexato do papel desem penhado pelo Ti na estrutura dêsses minerais, utilizar todo o cálcío. disponível, preferencialmente na formação da molécula da andradita.

Com o propósito de facilitar a leitura dêste traba-

tho, foi atribuído aos minerais analisados química ou radiocristalogrà ficamente o mesmo número de referência, gravado nas amostras de 
rochas das quais foram extraídos, acrescido das letras a, $\underline{b}, \underline{c}$ e $\underline{\mathrm{d}}$, quando designando, respectivamente, piroxênios, granadas, feldspatos e nefelina.

\section{Feldspatóides}

Nefelina

E o mineral mais importante do grupo e, dentre as rochas estudadas, sòmente não foi identificado nas amostras 22 e $\underline{33}$, quando então cancrinita parece ter-se formado em seu lugar. Macroscòpicamente, sua côr é variável, passando de branca a cinza, muito embora variedades de coloração rósea não sejam raras. Ao microscópio, usualmente, é xenomórfico-granular. Nas rochas porfiríticas é componente comum da matriz. Contudo, ocorre também como fenocris tal, especialmente em rochas de granulação fina, mostrando então formas geométricas regulares e caracterizadas principalmente pelo desen volvimento de prismas curtos fechados por pinacóide basal. São frequen tes inclusões líquidas, gasosas, ou mesmo de minerais, caso particular das acículas de piroxênio em algumas rochas de granulação fina. As vê zes, dispõem-se em arranjos concêntricos ou concordantes com à faces dos cristais.

Nas lâminas examinadas, a nefelina exibe sinais in discutíveis de alteração, provàvelmente de natureza hidrotermal. Cancrinita e um agregado mineralógico composto de várias espécies mine rais (ver Tabela II) são os dois produtos resultantes.

Cancrinita

E o principal produto de alter ação da nefelina, estan do presente nas 38 análises modais de rochas alcalinas levadas a efeito e, em duas delas (Am. 22 e 33), parece estar ocupando o lugar da nefe lina. Macroscòpicamente, distingue-se dos demais constituintes da ro cha por sua côr amarela característica. Evidências mineralógicas e estruturais, por exemplo, formação de cancrinita nas bordas e ao longo de fraturas dos cristais de nefelina (Fotomicrografia 1), indicativas da transformação de nefelina em cancrinita, foram observadas na maioria das amostras estudadas. Cancrinita é sempre xenomórfica e foi encon- 
trada, quer formando cristais isolados, quer integrando o agregado mi neralógico resul tante da decomposição de nefelina. $\mathrm{Na}$ amostra $\underline{22}$, re lativa a um cancrinita sienito portador de albita como feldspato domi nante (mariupolito, segundo a classificação de Johannsen, 1938, IV, p. 211), a cancrinita, a julgar pelas suas relações com os demais constituintes da rocha - ocupa os interstícios dos cristais de piroxênio e albita - parece ter sido o último mineral a se cristalizar. Enquanto esta rocha se mostra pràticamente inalterada, o mesmo não sucede com a amostra 33 , onde o teor de calcita secundária ascende a cêrca de $8,4 \%$ de seu volume. A cancrinita do mariupolito representaria um consti tuinte primário da rocha, enquanto que a cancrinita da amostra 33 seria de natureza secundária. A presença de cancrinita primária já é de há muito citada na literatura, tendo sido verificada, entre outros, por von Eckermann (1948) em juvitos, melanita juvitos e cancrinita juvitos do complexo alcalino da Ilha de Alnd, Suécia.

As determinações dos índices de refração de vários exemplares de cancrinita revelaram valores extremos $\mathrm{N}_{\mathrm{O}}=1,512$ e $\mathrm{N}_{\mathrm{e}}=1,495\left(\mathrm{Am} . \underline{22}\right.$ ) até $\mathrm{N}_{\mathrm{o}}=1,522$ e $\mathrm{N}_{\mathrm{e}}=1,501$ (Am. 29). A birre fringência, calculada a partir dêsses dados, é de 0,017 a 0,021.A apli cação dêsses valores no gráfico de variação óptico-química da série cancrinita-vishnevita de Deer et al. (1963, IV, p.316) permite verificar que êsses minerais se situam no campo das cancrinitas e cancrinitas-sulfáticas, contendo aproximadamente 10 a $35 \%$ da molécula de vi shnevita.

Agregado

O agregado microcristalino, referido anteriormente, constitui-se de vários minerais, a saber: nefelina, analcita, cancri nita, calcita, muscovita, sodalita, thomsonita (?) e variedades de hidro nefelinas. Usualmente, agregado e cancrinita individualizada estão presentes na mesma lâmina. Todavia, há amostras que são portadoras ape nas de um dêles (ver Tabelas Ia e Ib). Comumente a transformação da nefelina se processou por completo, conservando o agregado apenas a antiga forma externa dos cristais. Enalgumas rochas, for am reconhe cidos remanescentes dêsses minerais (Fotomicrografía 2); ;, ainda passíveis de identificação microscópica. Do ponto de vista óptico, o agregado se comporta, or a como material isótropo, or a como anisótro 
po, sendo possível no segundo caso identificar-se, face à alta birre w fringểncia, a presença de cristais de cancrinita e calcita.

Seis difratogramas de cristais de nefelina, em vários estádios de decomposição e representados na Fig. 7, foram execu tados com o propósito de identificar todos os constituintes formados a partir da alteração dêsse mineral. Para êsse "trabalho, utilitizamos as fichas de descrição mineralógica fornecidas pela "American Society for Testing Materials" (ASTM, 1965). Os resultados obtidos possibilita ram a elaboração da Tabela II, na qual são fornecidos, para cada amostra examinada, os valores de d, I (estimado visualmente)e o mi.neral correspondente. O exame desta tabela permite verificar que, ex cluídas as raias da nefelina, as demais correspondem às principais espécies minerais descritas na literatura como resultantes da alteração de nefelina. A amostra $\mathrm{X}$ é, dentre as estudadas, a que se encon tra em fase mais avançada de transformação. Apresenta porém, em linhas gerais, a mesma composição mineralógica das demais. Observa- se também os valores de $\underline{d}$, correspondentes às variedades de hi. dronefelinas (produtos sintéticos), estão presentes nas seis amostras examinadas. Tal fato é particularmente interessante porque parece contradizer as conclusões alcançadas por Edgar (1965, p. 987), em es tudo da composição mineralógica de produtos de alteração de nefelina, sôbre a possível inexistência de nefelinas hidratadas como espécies naturais.

Sodalita

Ocorre em alguns tinguaítos da província, quer co mo constituinte individualizado, quer substituindo cristais de nefelina. No primeiro caso, forma cristais maiores, alcançando até $7 \mathrm{~mm}$ de comprimento. Macroscőpicamente, sua presença foi notada em razão da côr azul característica. Medidas realizadas acusaram para o índice de refrração $(\underline{n})$ valores compreendidos entre 1,487 e 1,484 , corres pondendo, respectivamente, às amostras 19 e 18 da Fig. 4 .

Feldspatos

Excluindo-se o biotita melteigito, tôdas as variedades litológicas do distrito apresentam feldspatos em sua composição, 
Am. $x$

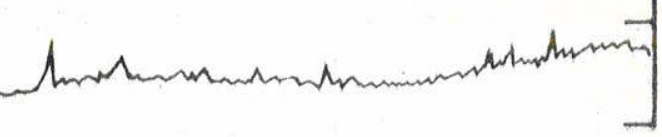

$18 d$

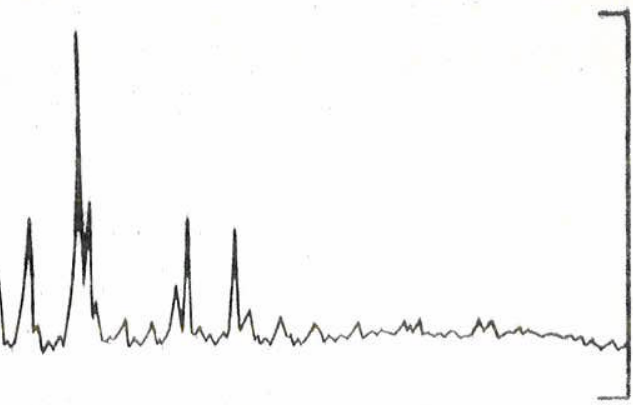

$\left[\begin{array}{c}\text { id } \\ 0\end{array}\right.$

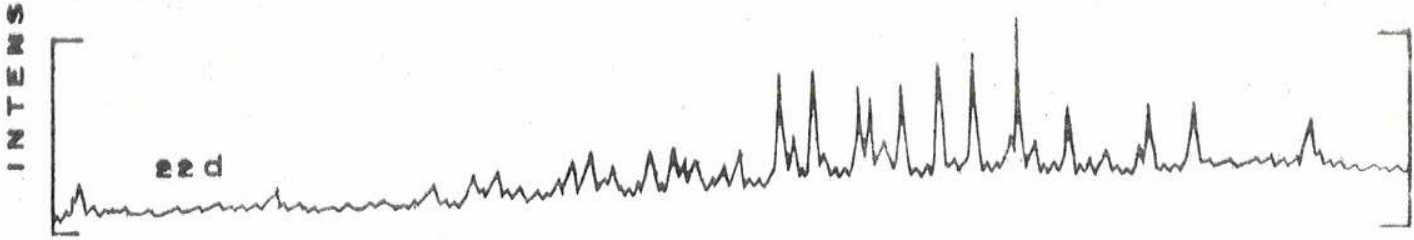

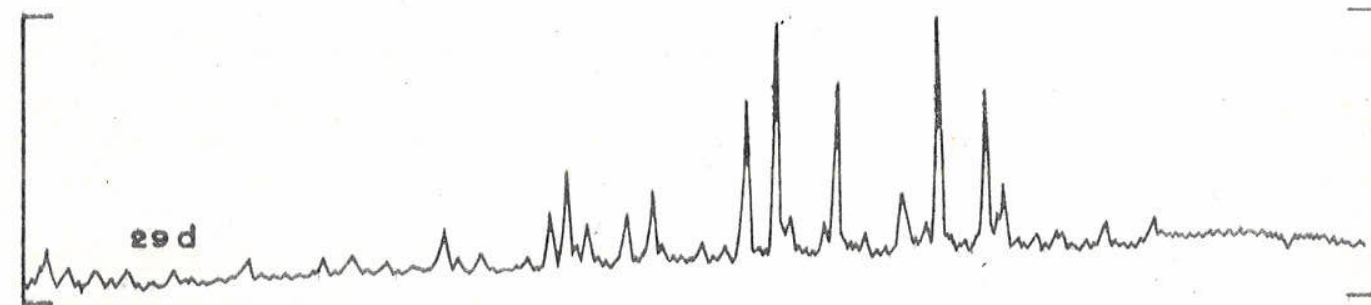

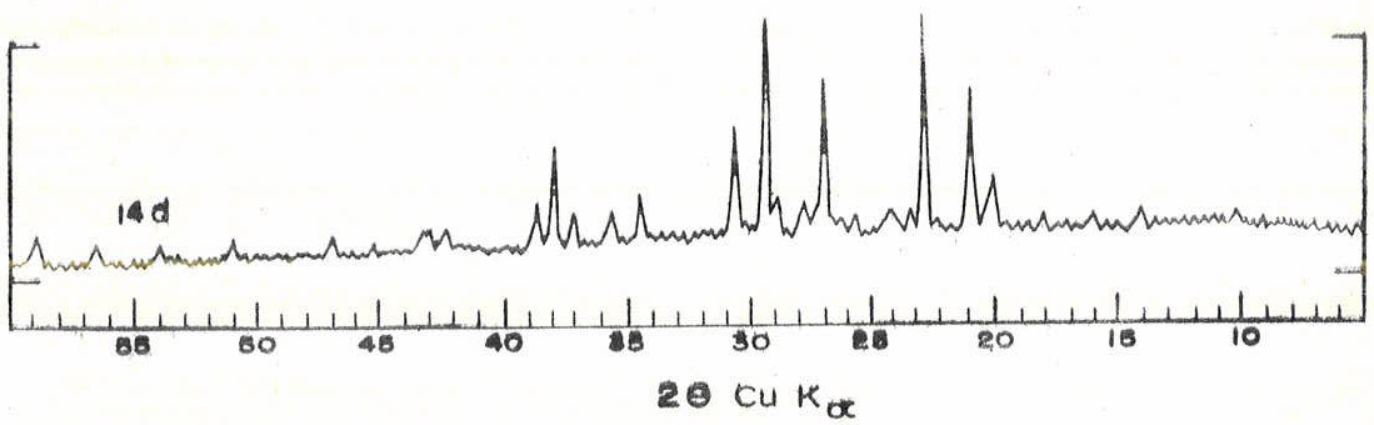

Fig. 7 - Difrotogramas de nefolina sous produtos de altaraģo. 
TABELA II

Análises de Raios $X$ de produtos de alteração de nefelin

\begin{tabular}{|c|c|c|c|c|c|c|c|c|c|c|c|c|c|c|c|c|c|}
\hline \multicolumn{3}{|c|}{$1 d$} & \multicolumn{3}{|c|}{$14 d$} & \multicolumn{3}{|c|}{$15 \mathrm{~d}$} & \multicolumn{3}{|c|}{$22 d$} & \multicolumn{3}{|c|}{$29 d$} & \multicolumn{3}{|c|}{ Amostza $x^{*}$} \\
\hline$ه(A)$ & Iest.) & Minerad & $d(A)$ & ; $4($ (stst) & Mineral & $d(A)$ & I(est.) & Minereal & d(A) & $1(s+s t)$. & Mineral & $d_{i}(\mathbf{A})$ & Ilesc.) & Mineral & $d(\mathbf{A})$ & f(est.) & Mineral \\
\hline 8,1 & 20 & FnI & 8,4 & 20 & test? & 8.2 & 10 & In I & 10,0 & 10 & M & 8,7 & 20 & He I? & 10,0 & 45 & M \\
\hline 6.3 & 25 & So & 6.3 & 25 & So & 6,3 & 10 & so & 6,3 & 55 & So & 8,3 & 20 & $\operatorname{Hn} I$ & 3.5 & 15 & $\operatorname{Hin} \mathrm{i}$ \\
\hline 5,5 & 20 & An & 5.6 & 20 & $A=$ & 5.6 & to & An & 5,6 & 55 & An & 8.0 & 20 & $\operatorname{En} I$ & 7.7 & 15 & fin $I$ \\
\hline 4,68 & 50 & $\mathrm{Ca}_{2}$ & $\therefore 98$ & 20 & Ne? & 4,98 & to & $M$ & 5,0 & $3 \theta$ & $\mathrm{M}$ & 6,3 & 25 & 50 & 5,0 & 20 & $\star x$ \\
\hline 4,32 & 20 & Né & 4.31 & 35 & Netinn If & 4.62 & 20 & $c_{a}$ & 4,84 & 25 & ת A & 5,6 & 25 & Ae & 4,19 & 10 & se \\
\hline 4.19 & 45 & Ne & 4.18 & 75 & $\mathrm{Ne}$ & 4,32 & 20 & $\mathrm{Ne}$ & 4,64 & 55 & $C_{2}$ & 5,3 & 20 & $\operatorname{Hin} I$ & 3,34 & 10 & $\mathrm{Ne}+\mathrm{f}$ \\
\hline 4,14 & 30 & Th? & 3,84 & 200 & $\mathrm{Ne}+\mathrm{Hn}$ II & 4,18 & 40 & $\mathrm{Ne}$ & 4,33 & 35 & $\mathrm{Ne}_{e}+\mathrm{C}_{2}$ & 4,98 & 20 & Ne & 3,35 & 50 & M \\
\hline 3.,84 & 70 & $\mathrm{Ne}+\mathrm{Hn}$ HI & 3.77 & 25 & Net? & 3,84 & 59 & $\mathrm{Ne}+\mathrm{FAn} \mathrm{I}$ & 4,19 & 100 & Ne & 4,62 & 20 & $c_{2}$ & 3,31 & so & M \\
\hline 3,75 & 20 & Net? & 3,63 & 25 & so & 3,77 & 30 & $\mathrm{Nat?}$ & 4,13 & 35 & Th? & 4. 31 & 40 & Net Hin II & 3.29 & 50 & Ne \\
\hline 3, 66 & 50 & $A_{2}+S_{0}$ & 3,43 & 20 & $\sin$ & 3,63 & 20 & 5o & 3. 84 & so & $\mathrm{Nen+Hn}$ II & 4,17 & 75 & $\mathrm{Ne}$ & 3,01 & 100 & $\mathrm{Ne}$ \\
\hline 3.64 & 60 & so & 3,27 & 75 & $\mathrm{Ne}$ & 3,45 & 20 & An & 3,64 & $\theta 0$ & so & 3.83 & 100 & $\mathrm{Ne}+\mathrm{Fin}$ II & 2,00 & 10 & M \\
\hline 3.62 & 60 & $\mathrm{Ca}_{\mathrm{a}}$ & 3,18 & 25 & Ne & 3. 34 & 20 & $\mathrm{Na}$ & 3,43 & 65 & An & 3.76 & 25 & Net? & & & \\
\hline 3,44 & 25 & $\mathrm{An}$ & 3.04 & 30 & ct & 3.27 & 60 & Ne & 3,34 & 35 & 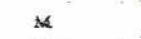 & 3,61 & 35 & so & & & \\
\hline 3,33 & 20 & $\mathrm{M}$ & $3, \infty 0$ & 100 & $\mathrm{Ne}$ & 3,23 & 100 & $C_{a}$ & 3,27 & 60 & $\mathrm{Ne}$ & 3,42 & 20 & An & & & \\
\hline 3,28 & 55 & Ne & 2., 88 & 35 & We & 3,04 & to & $\mathrm{Ct}$ & $3,2:$ & 65 & $\mathrm{Ca}$ & 3,26 & 75 & Ne & & & \\
\hline 3,23 & 65 & $\mathrm{Ca}$ & 2,57 & 35 & se & 3,00 & 50 & $\mathrm{Ne}$ & 3,01 & 75 & Ne & 3,22 & 25 & $\tau_{a}$ & & & \\
\hline 3,17 & 20 & Ne & 2,49 & 25 & $\mathrm{Ne}$ & 2.88 & 30 & $\mathrm{Ne}$ & 2,93 & to & An & 3,04 & 30 & $C t$ & & & \\
\hline 3,07 & 20 & Se & 2,39 & 25 & $\mathrm{Ne}$ & 2.73 & is & Hn II & 2,88 & 70 & re & 3.00 & 100 & $\mathrm{Ne}$ & & & \\
\hline 3,21 & 100 & $\mathrm{Ne}$ & 2,34 & 50 & Ne & 2,58 & 20 & we & 2,73 & 35 & Hin If & 2,92 & 20 & A & & & \\
\hline 2,38 & 40 & Ne & 2.31 & 30 & $\mathrm{Ne}$ & 2,50 & 20 & Ne & 2.69 & 25 & An & 2,88 & 70 & Ne & & & \\
\hline 2,30 & 60 & tant? & 2,12 & 20 & $\mathrm{Ne}$ & 2,40 & 10 & Ne & 2,62 & 25 & Kn I? & 2,79 & 15 & An & & & \\
\hline 2,78 & 25 & Aat? & 2,09 & 20 & $\mathrm{Ne}$ & 2,35 & 30 & Ne & 2,58 & 30 & Ne & 2,72 & 15 & $c_{2}$ & & & \\
\hline 2,74 & 25 & Fin II & 1,98 & 15 & $\mathrm{Ne}$ & 2. 31 & 20 & Ne & 2,56 & 40 & s & 2.58 & 35 & Ne & & & \\
\hline 2.71 & 30 & $\mathrm{Ca}$ & 1.69 & 15 & ve & 2. 19 & 10 & Ne & 2,50 & 40 & Ne & 2,49 & 30 & Ne & & & \\
\hline 2,63 & 20 & An !? & 1.62 & 15 & Ne & 2.16 & is & An & 2,40 & 25 & Ne & 2. $\neq 0$ & 25. & Ne & & & \\
\hline 2.58 & 30 & ve & 1,36 & 20 - & Ne & 2,12 & 10 & Ne & 2,35 & 35 & Ne & 2.34 & 45 & Ne & & & \\
\hline 2. 56 & 25 & $M$ & & & & 2.09 & 15 & Ne & 2,31 & 25 & Ne & 2. 30 & 30 & Xe & & & \\
\hline 2. 50 & 25 & Ne & & & & 1,93 & 15 & $\mathrm{Ne}$ & 2.25 & 20 & $A$ & 2., 16 & 15 & +\$ & & & \\
\hline 2,43 & 25 & An & & & & i. 38 & io & $\mathrm{Ne}$ & 2,16 & 20 & An & 2. 12 & 15 & ve & & & \\
\hline 2,40 & 20 & Ne & & & & 1,79 & 15 & $\mathrm{Ne}$ & 2,09 & 25 & ve & 2,09 & 25 & Ne & & & \\
\hline 2,35 & 25 & Ne & & & & 1.69 & 10 & Ne & 2,01 & 20 & M & 1.98 & 15 & $\mathrm{Ne}$ & & BREVLAÇOE & \\
\hline 2,31 & 20 & Ne & & & & 1,62 & 10 & $\mathrm{Ne}$ & 1,80 & 15 & Ne & 1.93 & 15 & $\mathrm{Ne}$ & $A_{n}=$ & Anatcita & \\
\hline 2.25 & 20 & $\mathrm{Ne}$ & & & & 1,56 & 20 & $\mathrm{Ne}$ & 1,56 & 30 & Ne & 1,89 & 15 & Ne & $c_{2}=$ & Cancrinita & \\
\hline 2,09 & 20 & $\mathrm{Ne}$ & & & & & & & & & & 1. 79 & 15 & Ne & $\mathrm{Ct}=$ & Calcita & \\
\hline 1.93 & 15 & Ne & & & & & & & & & & 1,69 & 10 & Ne & $\mathrm{Hn} I=$ & Hidronefel & etiana if \\
\hline 1.89 & to & $\mathrm{Ne}$ & & & & & & & & & & 1.61 & 15 & Ne & Hin II $=$ & Hidronefeft & thime II \\
\hline 1,34 & 20 & $\mathrm{Ne}$ & & & & & & & & & & 1. 56 & 20 & Ne & $\mathrm{Hn}$ III = & Hidronefet & tina III \\
\hline 1,80 & 20 & $\mathrm{Ne}$ & & & & & & & & & & & & & $M=$ & Muscorita & \\
\hline 1,70 & 20 & Ne & & & & & & & & & & & & & $N_{e}=$ & Netelina & \\
\hline 1,62 & 15 & Ne & & & & & & & & & & & & & $S_{0}=$ & Sodalitz & \\
\hline 1,56 & 15 & $\mathrm{Ne}$ & & & & & & & & & & & & & $\mathrm{Th}=$ & Thornsonit & \\
\hline
\end{tabular}


ora como grânulos equidimensionais, or a formando cristais maiores em rochas de granulação média a grossa e, principalmente, naquelas de granulação fina, caso particular dos tinguaítos. Em geral, mos . tram-se intercrescidos, originando preferencialmente estruturas mi cropertíticas e mesmo pertíticas, observação válida para o tipo domi nante. Plagioclásio albítico ocorre subordinadamente, quer como fa se mineralógìca das estruturas acima, quer formando indivíduos iso lados.

No presente trabalho, empregou-se o tếrmo felds pato alcalino, a exemplo de Deer et al. (1963, IV, p. 1), para desig nar as variedades contendo sódio-potássio e potássio em sua compo sição, excluindo-se portanto dêsse grupo a albita.

Feldspato alcalino

Ortoclásio, com baixo teor em soda, ú é felds pato presente nas rochas da província e ocorre indistintamente nas va riedades intrusivas e hipoabissais. Na maioria das vêzes, apresenta hábito placóide, paralelo à face (010), e mais raramente, alongado segundo o eixo cristalográfico $a_{9}$ sendo êste último mais frequente nos nefelina sienitos de granulação grossa. A côr é variável, predo minando, contudo, tonalidades claras como o branco e o branco-acin zentado. Variedades cinza-escuro e mesmo róseas não são de todo ra ras. Ao microscópio, é incolor, mostrando sempre nas rochas intru sivas indícios de alter ação, enquanto que nas variedades hipoabị sais tem como feição característica a extrema limpidez. Em geral, gemina-se segundo a lei de Carlsbad e, por vêzes, segundo Baveno, enquanto que a fase sódica da pertita o faz conforme a leì da albita. Por vêzes, mostra-se poiquilítico, sendo nefelina, piroxênio, granada e titanita as inclusões mais comuns. Suas dimensões são variáveis, passando de poucos milímetros, nas rochas tinguaíticas, a vários cen tímetros, nos nefelina sienitos de granulação grossa. Foram encontra das tôdas as gradações entre um material intensa e grosseir amente exsolvido e outro quase homogêneo, do ponto de vista óptico. Alguns dêstes cristais possuem em suas partes centrais regiões menos de misturadas que as bordas.

Informações ópticas de 5 exemplares de feldspa - 
tos, extraídos das amostras $\underline{4}, \underline{11}, \underline{14}, \underline{15}$ e 19 e fornecidas na Tabe 1a III, juntamente com os teores de $\mathrm{K}_{2} \mathrm{O}$ e $\mathrm{Na}_{2} \mathrm{O}$ dos quatro primeiros, permitem classificar êsses minerais como ortoclásio-micropertítico segundo Tuttle (1952) e Mackenzie e Smith (1955). Com exceção do va lor do $2 \mathrm{~V}$ da amostra $\underline{19 \mathrm{c}}$ (feldspato de tinguaíto), pouco maior do que o das demais, não se registraram variações signific ativas das proprie dades investigadas, estando aquelas, em geral, situadas dentro do cam po de êrro experimental. Utilizando-se o diagrama de variação de Tuttle (1952) que expressa composição do feldspato alcalino em têr mos das moléculas de Or e Ab e ângulo entre os eixos ópticos, esti ma-se a molécula do primeiro em aproximadamente 67 a $77 \%$. Usan do-se contudo, o diagrama de Tuttle (1952) que relaciona a composi ção com a variação dos índices de refração, observa-se que a porcen tagem da molécula de Or é maior, apresentando como valores extre mos 90 e $100 \%$. Resultados discrepantes, quando utilizados os dois diagramas, têm sido noticiados na literatura e são atribuídos, em sua maior parte, às limitações do segundo gráfico. Deer et al. (1963, IV , p.61) são de opinião que estimativas da composição de feldspatos alca linos, a partir do diagrama de variação com os índices de refração, de vem ser tomadas tão sòmente, como meras aproximações. A composi ção do feldspato da amostra 19c, quando usado o gráfico de variação do ângulo entre os eixos ópticos, acusa valor aproximado de $57 \%$ para a

TABELA III

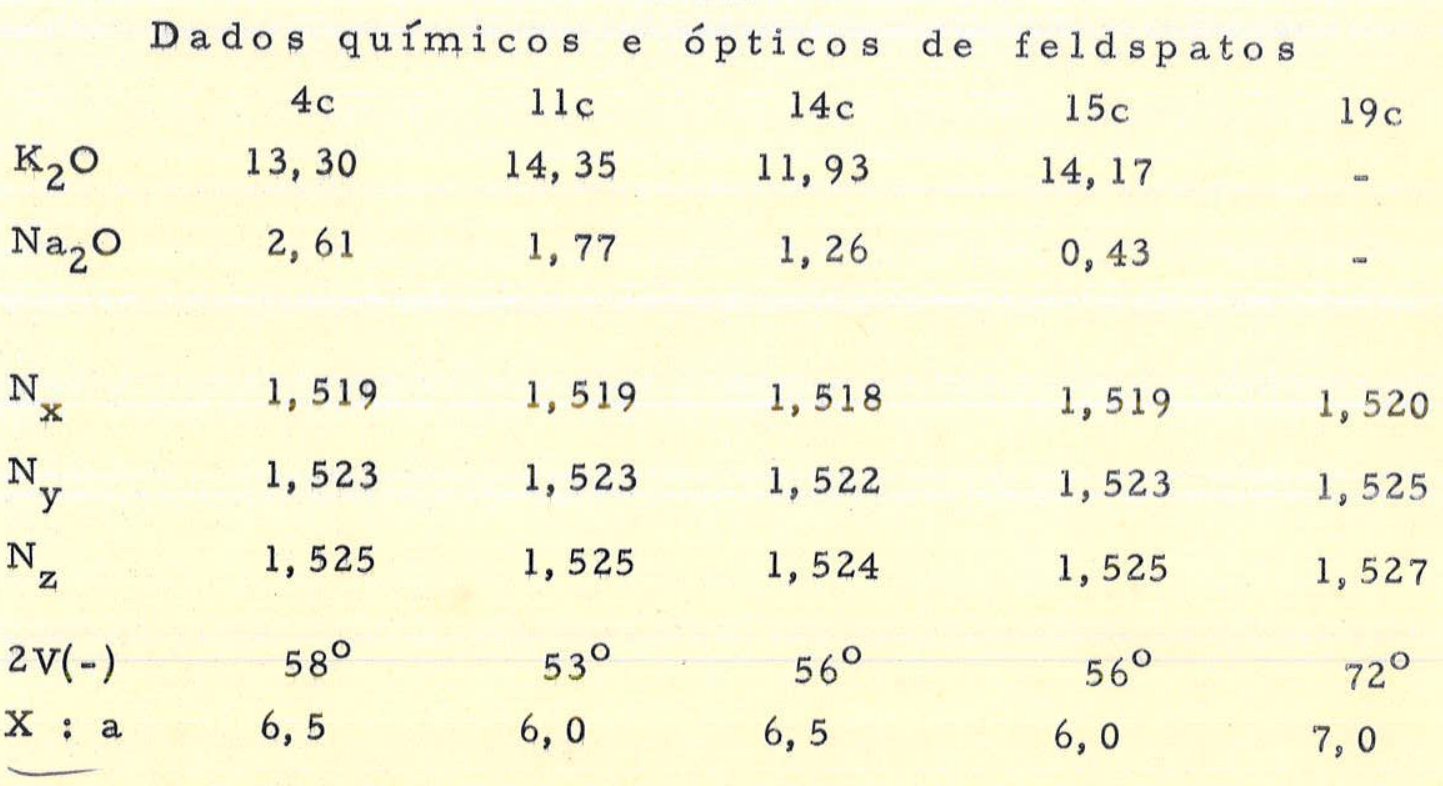


molécula de Or. A pequena porcentagem da molécula de Ab dos felds patos das outras variedades intrusivas está igualmente evidenciada pe lo baixo teor em $\mathrm{Na}_{2} \mathrm{O}$ dêsses minerais, como o demonstram as aná lises químicas parciais da Tabela III.

Plagioclásio

O plagioclásio das rochas de Itapirapuã é pràtica mente albita pura, com a molécula de anortita alcançando valor não superior a 5\%. Quando individualizados, os cristais apresentam di. mensões variáveis, tendo como valores extremos 0, 10 e 0,45 mm. Ao microscópio, diferem do feldspato alcalino pela sua maior limpi. dez e presença constante da geminação segundo a lei da albita. Sua forma é tabular segundo (010). Em alguns nefelina sienitos são relati vamente abundantes (até $20 \%$ da composição modal.), contudo, na majo ria das vêzes, estão presentes em quantidade bem menor, representando apenas a fase sódica dos ortoclásios pertíticos e micropertíti cos。

$$
\text { Piroxênios }
$$

Os piroxênios formam, ao lado das granadas, os minerais ferromagnesianos mais importantes das rochas de Itapira puã. Estão presentes na quase totalidade das amostras estudadas, exi bindo comumente formas próprias. Constituem aparentemente uma sé rie única de clinopiroxênios, cujos membros principais, a julgar pe las propriedades ópticas e dados químicos, são: soda-augita, egirina - augita e egirina.

Análises químicas, incluindo elementos traços, de dez amostras extraídas de rochas da província estão contidas na Tabe la IV, enquanto suas normas moleculares estão expostas na Tabela V. As fórmulas químicas dêsses minerais, expressas na base de 6 áto mos de oxigênio, constam da Tabela VI.

A nomenclatura adotada para os piroxênios sódi cos é a de Tróger (1965, p. 64), que consiste em estabelecer os cam pos de soda-augita, egirina-augita e egirina, compreendidos, respec tivamente, nos limites $0-25 \%, 25-75 \%$ e $75-100 \%$ da molécul a de Eg 
TABEILA IV

Análises químicas: Piroxênios

\begin{tabular}{|c|c|c|c|c|c|c|c|c|c|c|}
\hline & $\begin{array}{l}\text { Soda- } \\
\text { augita }\end{array}$ & & & & Egiri & a-augitas & & & & Egirine \\
\hline \% Pêso & la & $2 a$ & $6 a$ & $7 a$ & $14 \mathrm{a}$ & $12 a$ & $16 a$ & $17 \mathrm{a}$ & $13 a$ & $22 a$ \\
\hline $\mathrm{SiO}_{2}$ & 48,15 & 49,19 & 50,01 & 48,81 & 49,24 & 49,72 & 50,68 & 50,82 & 50,48 & 51,35 \\
\hline $\mathrm{TiO}_{2}$ & 1,35 & 1,01 & 0,55 & 0,70 & 0,60 & 0,45 & 0,99 & 0,60 & 0,60 & 1,10 \\
\hline $\mathrm{Al}_{2} \mathrm{O}_{3}$ & 4,07 & 3,02 & 1,97 & 2,16 & 2,00 & 2,19 & 3,18 & 2,32 & 2,88 & 2,15 \\
\hline $\mathrm{Fe}_{2} \mathrm{O}_{3}$ & 5,66 & 10,01 & 12,34 & 13,03 & 16,92 & 17,72 & 18,43 & 20,32 & 23,72 & 28,66 \\
\hline $\mathrm{FeO}$ & 5,40 & 7,45 & 7,37 & 6,81 & 9,92 & 8,02 & 6,32 & 4,86 & 3,62 & 2,24 \\
\hline $\mathrm{MnO}$ & 0,24 & 0,41 & 0,64 & 0,62 & 0,71 & 0,50 & 1,06 & 0,97 & 0,76 & tr \\
\hline $\mathrm{MgO}$ & 21,61 & 6,62 & 5,72 & 5,00 & 1,95 & 2,50 & 2,37 & 2,32 & 1,52 & 0,10 \\
\hline $\mathrm{CaO}$ & 20,02 & 19,40 & 16,01 & 18,27 & 11,93 & 11,05 & 9,32 & 8,26 & 5,70 & 1,25 \\
\hline $\mathrm{Na}_{2} \mathrm{O}$ & 2,30 & 3,40 & 5,20 & 4,72 & 6,72 & 7,42 & 7,52 & 8,37 & 10,81 & 12,66 \\
\hline $\mathrm{K}_{2} \mathrm{O}$ & 0,34 & 0,24 & 0,20 & 0,52 & 0,24 & 0,24 & 0,54 & 0,48 & 0,21 & 0,15 \\
\hline $\mathrm{H}_{2} \mathrm{O}^{+}$ & 0,59 & 0,10 & 0,18 & 0,21 & 0,23 & 0,31 & 0,14 & 0,14 & 0,16 & 0,12 \\
\hline $\mathrm{H}_{2} \mathrm{O}^{-}$ & 0,08 & 0,07 & 0,05 & 0,19 & 0,17 & 0,01 & - & 0,19 & 0,18 & 0,17 \\
\hline Total & 99,81 & 100,92 & 100,72 & 101,04 & 100,63 & 99,04 & 100,55 & 99,65 & 100,64 & 99,95 \\
\hline \multicolumn{11}{|l|}{ Ppm } \\
\hline $\mathrm{Ga}$ & 16 & 17 & 14 & 13 & 46 & 20 & 30 & 30 & 22 & 38 \\
\hline $\mathrm{Cr}_{\mathrm{r}}$ & 96 & 20 & nd & 16 & nd & nd & nd & nd & nd & 2 \\
\hline $\mathrm{v}$ & 230 & 360 & 260 & 200 & 400 & 280 & 400 & 340 & 154 & 44 \\
\hline $\mathrm{Nb}$ & 30 & 70 & 16 & 50 & 40 & 16 & 108 & 116 & 166 & 114 \\
\hline $\mathrm{Ni}$ & 62 & 8,8 & 6 & 14 & 12 & 8 & 14 & 10 & 8 & 4 \\
\hline Co. & 32 & 22 & 30 & 10 & 30 & 22 & 18 & 16 & 18 & 8 \\
\hline $\mathrm{Cu}$ & 8 & 6 & 22 & 18 & 28 & 22 & 26 & 24 & 95 & 32 \\
\hline $\mathrm{Sc}$ & 26 & 18 & nd & 8 & nd & nd & nd & nd & nd & nd \\
\hline$z_{x}$ & 760 & 1260 & 1120 & 720 & 2400 & 1240 & 1920 & 2400 & 2600 & 2400 \\
\hline $\mathrm{Y}$ & 30 & 94 & 38 & 38 & 66 & 20 & 22 & 36 & 36 & nd \\
\hline La & nd & nd & nd & nd & 100 & nd & nd & nd & 196 & nd \\
\hline Sx & 960 & 1160 & 920 & 800 & 600 & 800 & 500 & 280 & 420 & 230 \\
\hline $\mathrm{Pb}$ & $\mathrm{nd}$ & 16 & 32 & 30 & 40 & 20 & 76 & 40 & 40 & nd \\
\hline $\mathrm{Ba}$ & 96 & 112 & 90 & 160 & 40 & 52 & 52 & 68 & 46 & 120 \\
\hline
\end{tabular}

Aralisias: Elementos priacipais - Silvia Lo rdes Mo (I.P.T.) 
TABELA V

Normas moleculares: Piroxênios

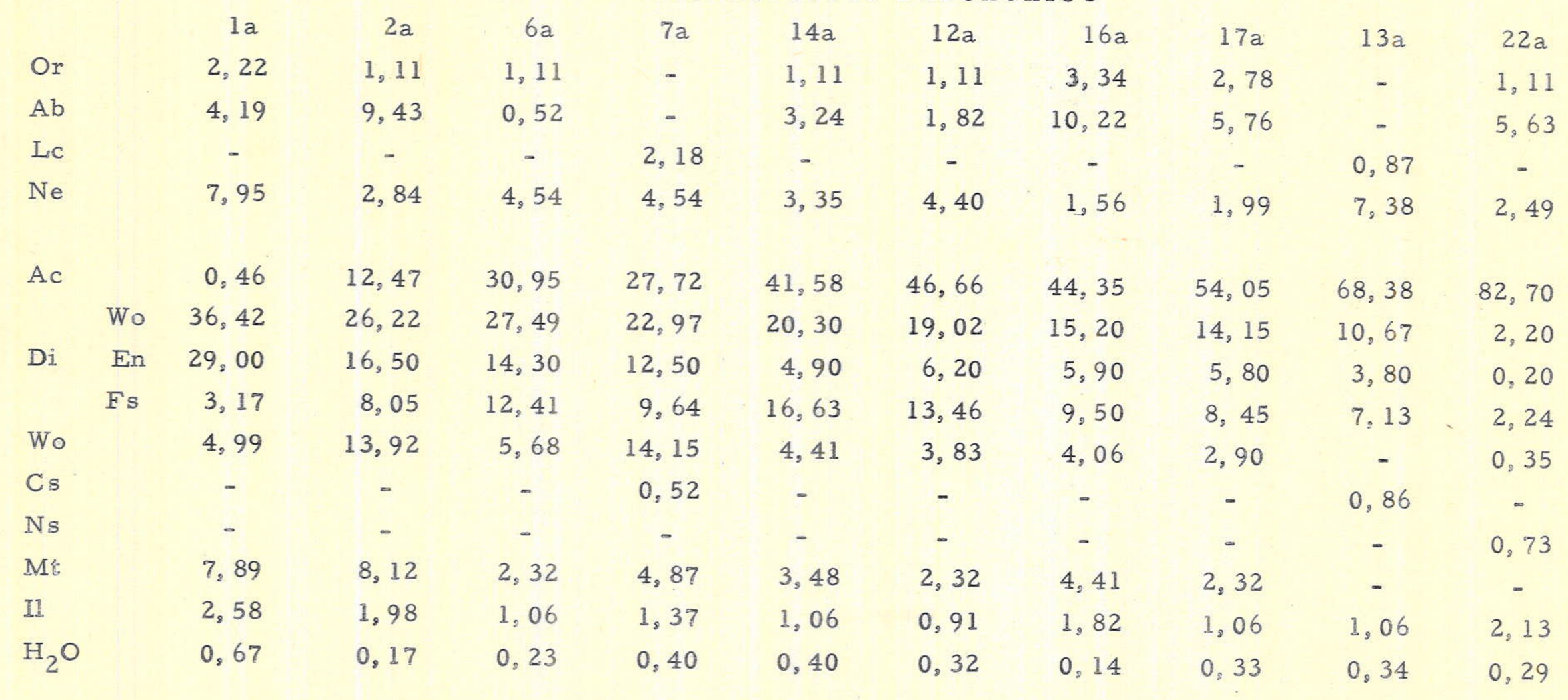

Total $99,54 \quad 100,85 \quad 100,61 \quad 100,86 \quad 100,46 \quad 100,05 \quad 100,50 \quad 99,59 \quad 100,49 \quad 99,78$ 
TABELA VI

Fórmulas químicas dos piroxênios analisados (na base de 6 átomos de oxigênio)

\begin{tabular}{|c|c|c|c|c|c|c|c|c|c|c|c|}
\hline & & la & $2 a$ & $6 a$ & $7 a$ & $14 a$ & $12 \mathrm{a}$ & $16 a$ & $17 a$ & $13 a$ & $22 a$ \\
\hline \multirow{3}{*}{ z } & $\mathrm{Si}_{\mathrm{i}}$ & 1,830 & 1,865 & 1,932 & 1,889 & 1,930 & 1,939 & 1,943 & 1,996 & 1,938 & 1,975 \\
\hline & Al & 0,119 & 0,108 & 0,040 & 0,070 & 0,049 & 0,037 & 0,071 & 0,038 & - & - \\
\hline & $\mathrm{Ti}$ & - & - & - & - & - & - & - & - & 0,018 & 0,032 \\
\hline \multirow{9}{*}{ WXY } & Al & 0,064 & 0,026 & 0,049 & 0,028 & 0,042 & 0,063 & 0,071 & 0,066 & 0,129 & 0,097 \\
\hline & $\mathrm{Ee}^{3+}$ & 0,162 & 0,284 & 0,354 & 0,378 & 0,496 & 0,517 & 0,529 & 0,590 & 0,684 & 0,826 \\
\hline & $\mathrm{Fe}^{2+}$ & 0,171 & 0,234 & 0,234 & 0,220 & 0,324 & 0,260 & 0,202 & 0,155 & 0,115 & 0,072 \\
\hline & $\mathrm{Mn}$ & 0,007 & 0,017 & 0,021 & 0,021 & 0,023 & 0,016 & 0,034 & 0,032 & 0,025 & - \\
\hline & $\mathrm{Mg}$ & 0,662 & 0,375 & 0,329 & 0,290 & 0,115 & 0,145 & 0,136 & 0,135 & 0,087 & $0,00 t$ \\
\hline & $\mathrm{Ca}$ & 0,814 & 0,787 & 0,657 & 0,756 & 0,501 & 0,461 & 0,382 & 0,341 & 0,235 & 0,022 \\
\hline & $\mathrm{Na}$ & 0,169 & 0,250 & 0,386 & 0,353 & 0,510 & 0,559 & 0,559 & 0,627 & 0,804 & 0,941 \\
\hline & K & 0,016 & 0,011 & 0,009 & 0,025 & 0,012 & 0,012 & 0,025 & 0,023 & 0,009 & 0,007 \\
\hline & $\mathrm{Ii}$ & 0,039 & 0,029 & 0,016 & 0,021 & 0,016 & 0,014 & 0,027 & 0,016 & - & - \\
\hline \multicolumn{2}{|l|}{ z } & 1,95 & 1,97 & 1,97 & 1,96 & 1,98 & 1,98 & 2,01 & 2,00 & 1,96 & 2,01 \\
\hline \multicolumn{2}{|l|}{ WXY } & 2,10 & 2,01 & 2,05 & 2,09 & 2,04 & 2,05 & 1,97 & 1,98 & 2,09 & 2,00 \\
\hline \multicolumn{2}{|c|}{$\%$ Al em Z } & 6,1 & 5,5 & 2,0 & 3,6 & 2,5 & 1,9 & 3,5 & 1,9 & - & - \\
\hline \multicolumn{2}{|c|}{$\%$ Ti em Z } & - & - & - & - & - & - & - & - & 0,9 & 1,6 \\
\hline
\end{tabular}

$\begin{array}{lllllllllrrr}\mathrm{Ca} & 44,9 & 46,4 & 41,2 & 45,4 & 34,3 & 32,9 & 29,7 & 27,2 & 20,5 & 5,3 \\ \mathrm{Mg} & 36,4 & 22,1 & 20,6 & 17,4 & 7,9 & 10,4 & 10,6 & 10,8 & 7,6 & 0,6 \\ \mathrm{Fe}^{*} & 18,7 & 31,5 & 38,2 & 37,2 & 57,8 & 56,7 & 59,7 & 62,0 & 71,9 & 94,1 \\ \mathrm{Na}+\mathrm{K} & 16,2 & 28,8 & 37,7 & 41,6 & 51,7 & 55,1 & 58,7 & 64,6 & 75,0 & 91,4 \\ \mathrm{Mg} & 66,0 & 41,4 & 35,1 & 31,9 & 12,0 & 15,5 & 15,0 & 14,8 & 9,6 & 0,7 \\ \mathrm{Fe}^{\prime} & 17,8 & 29,8 & 27,2 & 26,5 & 36,3 & 29,4 & 26,3 & 20,6 & 15,4 & 7,9 \\ \% \mathrm{~mol} . \mathrm{Eg} & 16 & 26 & 35 & 38 & 50 & 52 & 53 & 59 & 68 & 83\end{array}$

$\mathrm{Fe}^{*}=\mathrm{Fe}^{2+}+\mathrm{Fe}^{3+}+\mathrm{Mn}$

$\mathrm{Fe}^{t}=\mathrm{Fe}^{2+}+\mathrm{Mn}\left(\mathrm{Fe}^{3+}\right)$ 
(egirina).

Dadas as divergências de terminologia existentes para a série dos piroxênios sódicos, vimo-nos obrigados neste tra. balho a apresentar a composição dêsses minerais, ora em têrmos da molécula de Eg (egirina), ora em têrmos da molécula de Ac (acmita). Contudo, cabe destacar que em ambos os casos iremos nos feferir a uma mesma espécie mineralógica, cuja composição teórica pode ser expressa pela fórmula química $\mathrm{NaFe}^{3+} \mathrm{Si}_{2} \mathrm{O}_{6}$.

Soda-augita

Soda-augita foi identificada em uma única variedade litológica do distrito, o biotita melteigito (Am。 1a), aparecendo, ora na forma de fenocristal, or a como componente de sua massa fundamental. Sua coloração é esverdeada clara, algo parda centa, o hábito prismático e as dimensões variáveis, passando de fração de milímetros $(0,20-0,30 \mathrm{~mm})$, quando integrante da matriz, até cêrca de $1,80 \mathrm{~mm}$, quando presente na forma de fenocristal. Chis tais zonados (Fotomicrografia 3), com as bordas dos indivíduos apresentando-se mais fortemente coloridas são bem frequenteș.O pleo croísmo é mais intenso nas bordas dos cristais, sendo neste ca so $\mathrm{X}>\mathrm{Y}>\mathrm{Z}$. Em razão da estrutura zonada, estabeleceu-se dois padrões de côres (Tabela VII), o primeiro referente ao núcleo dos cristais e o segundo relativo às suas partes marginais. De modo ge ral, $X$ varia de verde-pardacento a verde, Y de pardo-amarelado a verde-pardacento, enquanto que $Z$ é pardo. Geminação segundo (100) foi observada em pouquîssimos grânulos. Os valores determinados para algumas de suas constantes ópticas constam da Tabela VII e são os seguintes: $N_{y}=1,713 ; \mathrm{X}: c=45^{\circ}$ e $2 \mathrm{~V}(+)=55^{\circ}$. Medidas determinadas nas partes marginais dos cristais zonados acusaram valores mais altos para o ângulo entre os eixos ópticos e o ín dice de refração e menores para o ângulo de máxima extinção inclinada, com $X$ vibrando mais próximo da clivagem. Tais fatos indi cam que as bordas dêsses piroxênios são de egirina-augita. O exame da análise química (Am. la da Tabela IV) permite verificar que, ao lado dos teores comparativamente elevados em cálcio e magnésio e baixos em ferro trivalente e sódio, 
TABELA VII

Propriedades ópticas de piroxênios

$\begin{array}{ccc} & 1 \mathrm{a} & 2 \mathrm{a} \\ \mathrm{N}_{\mathrm{y}} & 1,713 & 1,722 \\ 2 \mathrm{~V} & 55(+) & 80(+) \\ \mathrm{X}: \mathrm{c} & 45^{\circ} & 30^{\circ}\end{array}$

$6 \mathrm{a}$
1,735
$90^{\circ}$
$21^{\circ}$

$7 a$
1,736
$90^{\circ}$
$18^{\circ}$

$14 a$
1,757
$82(-)$
$13^{\circ}$

$\begin{array}{cc}12 a & 16 a \\ 1,762 & 1,764 \\ 82(-) & 81(-) \\ 11^{\circ} & 12^{\circ}\end{array}$

$17 a$
1,765
$72(-)$
$7^{\circ}$

$\begin{array}{cc}13 a & 22 a \\ 1,782 & 1,797 \\ 70(-) & 64(-) \\ 5^{\circ} & 5^{\circ}\end{array}$
a) verde - a) pardo -
$\mathrm{X}$ pardacento esverdeado

$\begin{array}{lll}P & \text { b) verde } & \text { b) verde } \\ 1 & & \\ e & \text { a) pardo - } & \text { a) pardo- } \\ 0 & \text { amarelado amarelado }\end{array}$

y amarelado amarelado
b) verde - b) verde pardacento claro

verde

verde

verde

escuro

verde

verde escuro

verde

verde

verde

verde- verde- verde

verde

amarelado

oliva

claro

verde

verde-

verdeardacento

m
a) pardo
a) ardo
b) pardo
b) pardo -

amarelo-
esverdeado

amarelo

pardoamarelado

amarelopardo-

amareloesverdeado

amareloesverdeado

pardo claro
a) núcleo;
b) borda. 
- mineral mostra-se altamente aluminoso e algo deficiente em sullica. Esta deficiência em Si ( Tabela VI) é, em parte, compensada pelo Al. que ocupa cêrca de $6,1 \%$ do grupo $Z$. Quanto aos elementos traços, ob serva-se que a soda-augita distingue-se dos demais piroxênios da sé rie em virtude do seu conteúdo mais alto em $\mathrm{Cr}$, Ni, Sce Coe, em geral, mais baixo em Cu, Zr e Nb.

Egirina-augita

Egirina-augita é o membro mais comum da série. sendo encontrado em quase tôdas as rochas examinadas, formando in divíduos zonados ou não. A côr é verde, em tonalidades claras e es curas e as dimensões variáveis, tendo como valores limites $0,02 \mathrm{~mm}$ (tinguaitos) e $3,0 \mathrm{~cm}$ (nefelina sienitos de granulação grossa). Ocor rem normalmente como prismas. De hábito acicular são frequentes nos tinguaítos e fibrorradial em alguns nefelina sienitos de granula w ção fina. O pleocroísmo é marcante e sua fórmula $X>Y>Z$. As côres variam de pardo-esverdeado a verde-garrafa para $X$, pardo-ama relado a verde para $\mathrm{Y}$ e pardo a amarelo-esverdeado para $Z$. Os cristais não homogêneos ostentam freqtentemente núcleo verde cir cundado por um manto de color ação mais viva e de composição mais egirinica. $\mathrm{Na}$ amostra $2 \mathrm{a}$, em virtude da estrutura zonada, procurou - se distinguir, a exemplo do sucedido com a soda-augita, dois pa dröes de côres (Tabela VII); um dizendo respeito ao centro dos cris tais e outro às suas bordas. As medidas ópticas obtidas indicam, segundo o diagrama de variação da série de Trbger (1956, p.64), que ếs ses minerais possuem composição muito variável, tendo como têr mos extremos as amostras $2 \mathrm{a}$ e $13 \mathrm{a}$, portadoras, respectivamente. de 25 e $65 \%$ da molécula de Eg. Os dados obtidos integram a Tabela VII e os valores limites são os seguintes: $N_{y}=1,722$ a $1,782: X: c=$ $=30^{\circ}$ a $5^{\circ}$ e $2 \mathrm{~V}=80^{\circ}(+)$ a $70^{\circ}(-)$.

As análises químicas de egirina-augitas, amostras 2 a até $13 \mathrm{a}$ da Tabela IV, mostram variações regulares e antipatéti cas para os seus teores de $\left(\mathrm{Na}_{2} \mathrm{O}\right.$ e $\left.\mathrm{Fe}_{2} \mathrm{O}_{3}\right)$ e(CaO e $\left.\mathrm{MgO}\right)$. Tal fato é melhor evidenciado nas porcentagens crescentes e decrescentes de seus minerais normativos, acmita, wollastonita e enstatita (Tabe la V), sendo êstes dois últimos componentes da molécula de diopsí - 
dio. As porcentagens da molécula de Eg dêsses minerais, obtidas a partir do número de íons de $\mathrm{Fe}^{3+}$ por fórmula unitária (Tabela VI), guar dam razoável concordância com os valores conseguidos diretamente no diagrama de variação óptica da Fig. 9. Quanto aos elementos traços, verifica-se que, com exceção de $\mathrm{Zr}$, $\mathrm{Nb}$ e $\mathrm{Sr}$, os demais não apresen tam variações marcantes que possibilitem estabelecer relações, quer entre si, quer envolvendo os elementos principais.

Egirina

Egirina, contendo $82,7 \%$ da molécula de $\mathrm{NaFe}^{3+} \mathrm{Si}_{2} \mathrm{O}_{6}$, foi identificada numa única rocha do distrito, o cancri. nita mariupolito ( $\mathrm{Am}$. 22a $)$. Seu hábito é prismático, por vêzes fibror radial, os cristais individuais situando-se ao redor de $0,25 \mathrm{~mm}$. A côr é verde e ao microscópio exibe, ao lado de idiomorfismo parcial, pleo croísmo não muito intenso em $\mathrm{X}=$ verde-claro, $\mathrm{Y}=$ verde-pardacento e $Z=$ pardo-claro. Geminação (100) é rara e a dispersão $(r>v)$ moderada. Suas propriedades ópticas (Tabela VII) são $\mathrm{N}_{\mathrm{y}}=1,797 ; \mathrm{X}_{\mathrm{c}} \mathrm{c}=5^{\circ}$ e $2 \mathrm{~V}(-)=64^{\circ}$. A êstes dados, corresponde segundo Trbger (1956, p. 64) um mineral com cêrca de $78 \%$ da molécula de Eg (Fig.9)。Este valor revela-se similar ao obtido diretamente da análise química e fornecido a.cima。

Do ponto de vista químico, tem como feição distin tiva os teores marcantes em $\mathrm{Na}_{2} \mathrm{O}$ e $\mathrm{Fe}_{2} \mathrm{O}_{3}$, que refletem a elevada por centagem da molécula de A.c (82,7\%, Tabela IV). Cabe ressaltar tam bém a pobreza do mineral em manganês, constituindo-se tal fato, mui to provàvelmente, o fator responsável pelo seu fraco pleocroísmo.

\section{Granadas}

As granadas constituem um dos minerais aciden . taîs mais comuns das rochas de Itapirapuã e informações sôbre a fre quência com que ocorrem já for am dadas na parte introdutória do presente capítulo. Macroscòpicamente, têm côr preta, porém, quando examinadas ao microscópio êsses minerais mostram coloração casta nha, em tonalidades clara/s e escuras. As dimensões variam dentro das classes $0,20-0,46 \mathrm{~mm}$ e $0,15-0,85 \mathrm{~cm}$, sendo que no segundo ca- 
so, freqtentemente, exibem estrutura poiquilítica tendo como inclu sões os demais constituintes da rocha, em especial, piroxênios e ti tanita, Idiomorfismo parcial, ou mesmo completo, isotropia, alto ín dice de refração, ao lado da estrutura zonada (Fotomicrografia 4), são as suas feições microscópicas mais características. Esta estrutura é quase sempre evidenciada pela variação nas tonalidades de pardo que se observam nas diferentes zonas do cristal. Tais alternâncias em granadas ricas em cálcio e ferro terivalente têm sido interpretadas como resultantes do seu conteúdo variável em titânio, enquanto que Zedlitz (1935) considerou-as como devidas ao titânio e ferro presen tes no mineral em diferentes estádios de oxidação.

Foram executadas análises químicas, incluindo elementos traços, de 7 exemplares extraídos de rochas do distrito e os resultados são fornecidos na Tabela VIII em ordem decrescente do teor de óxido de titânio. As fórmulas químicas, expressas na base de 24 âtomos de oxigênio, integram a Tabela IX, juntamente com os da dos relativos a índices de refração (n), pêso específico (D) e parâme tro da cela unitária ( $\left.a_{0}\right)$. De acôrdo com a nomenclatura proposta por Zedlitz (1933, pp. 225-226) - que subdivide as granadas portadoras de titânio, nas variedades melanita e schorlomita, estabelecendo os valores limites de $0-15 \%$ e superior a $15 \% \mathrm{TiO}_{2}$, respectivamente, para o primeiro e segundo mineral - e, considerando os teores apre sentados pelas amostras examinadas, verifica-se que estas situam-se tôdas no campo da melanita dêsse Autor.

A exceção do óxido de titânio, todos os demais óxidos parecem não revelar variações significativas nos vários exemplares pesquisados. O fato da relação $R_{2}: R_{2} O_{3}: R O$ mostrar-se um pouco distante dos valores teóricos $3: 2: 3$, citados na literatura como ca racterísticos do grupo das granadas, é interpretado como resultante, entre outros, de dois fatôres: a) como já referido, falta de conheci mento da posição exata de Ti na estrutura dêsses minerais, e b) pre sença de impurezas, representadas principalmente pelos teores de $\mathrm{Na}_{2} \mathrm{O}$ e $\mathrm{K}_{2} \mathrm{O}$. A presença da molécula da andradita, correspondendo a aproximadamente $90 \%$ da granada, serve para bem realçar a sua natu. reza cálcico-férrica.

O exame da Tabela IX permite também observar que Ti está presente no grupo $\mathrm{RO}_{2}$ tão sòmente em duas amostras ana 
TABELA VIII

Análises químicas: Granadas

\begin{tabular}{lrrrrrrr}
$\% \mathrm{PêBo}$ & $2 \mathrm{ab}$ & \multicolumn{1}{c}{$2 \mathrm{~b}$} & $9 \mathrm{~b}$ & $32 \mathrm{~b}$ & \multicolumn{1}{c}{$3 \mathrm{~b}$} & \multicolumn{1}{c}{$4 \mathrm{~b}$} & $39 \mathrm{~b}$ \\
$\mathrm{SiO}_{2}$ & 31,31 & 32,68 & 32,93 & 33,31 & 35,32 & 34,19 & 33,55 \\
$\mathrm{TiO}_{2}$ & 8,72 & 6,97 & 6,59 & 5,88 & 4,75 & 4,56 & 4,49 \\
$\mathrm{Al}_{2} \mathrm{O}_{3}$ & 2,18 & 3,58 & 3,00 & 2,81 & 1,89 & 2,26 & 1,70 \\
$\mathrm{Fe}_{2} \mathrm{O}_{3}$ & 23,27 & 23,05 & 25,18 & 23,95 & 25,66 & 26,30 & 25,35 \\
$\mathrm{FeO}$ & 2,11 & 2,42 & 2,32 & 2,08 & 2,77 & 2,07 & 2,89 \\
$\mathrm{MnO}$ & 0,24 & 0,26 & 0,22 & 0,15 & 0,26 & 0,25 & 0,01 \\
$\mathrm{MgO}$ & 0,81 & 0,74 & 0,37 & 0,94 & 0,65 & 0,54 & 0,89 \\
$\mathrm{CaO}$ & 31,16 & 30,08 & 29,16 & 30,61 & 28,58 & 29,70 & 30,91 \\
$\mathrm{Na}$ & 0,27 & 0,52 & 0,62 & 0,34 & 0,96 & 1,05 & 0,21 \\
$\mathrm{~K}_{2} \mathrm{O}$ & 0,09 & 0,13 & 0,16 & 0,01 & 0,04 & 0,12 & 0,46
\end{tabular}

Total $\quad 100,26 \quad 100,43 \quad y 00,55 \quad 100,08 \quad 100,88 \quad 101,04 \quad 100,46$

ppm

$\begin{array}{lrrrrrrr}\mathrm{Ga} & 23 & 24 & 8 & 26 & 30 & 23 & 22 \\ \mathrm{Cr} & 24 & 20 & 20 & 12 & 20 & 8 & 22 \\ \mathrm{~V} & 720 & 740 & 800 & 900 & 840 & 880 & 840 \\ \mathrm{Nb} & 500 & 260 & 490 & 440 & 148 & 220 & 360 \\ \mathrm{Ni} & 40 & 38 & 38 & 42 & 40 & 46 & 42 \\ \mathrm{Co} & \mathrm{nd} & \mathrm{nd} & 12 & \text { nd } & \text { nd } & \text { nd } & \text { nd } \\ \mathrm{Cu} & 3 & 4 & 26 & 2 & 3 & 2 & 3 \\ \mathrm{Sc} & 20 & 19 & \text { nd } & 18 & 18 & 18 & 18 \\ \mathrm{Zr} & 1900 & 2300 & 2600 & 3400 & 2900 & 2900 & 1640 \\ \mathrm{Y} & 420 & 640 & 220 & 460 & 500 & 460 & 230 \\ \mathrm{La} & \mathrm{nd} & \text { nd } & \text { nd } & \text { nd } & \text { nd } & \text { nd } & \text { nd } \\ \mathrm{Sr} & 134 & 360 & 230 & 140 & 108 & 164 & 96 \\ \mathrm{~Pb} & 8 & \text { nd } & 32 & 30 & 10 & 8 & 30 \\ \mathrm{Ba} & 56 & 52 & 100 & 48 & 40 & 56 & 48\end{array}$

Analistas: Elementos principais - Raphael Hypolito (D. M.P.).

Elementos traços - Cláudio Vieira Dutra (I. T.I.).

As granadas $32 \mathrm{~b}$ e $39 \mathrm{~b}$ for am extraídas de veios cortando as amos$\operatorname{tras} 32$ e 39. 


\section{TABELA IX}

Fórmulas químicas das granadas analioadas (na base de 24 átomos de oxigênio)

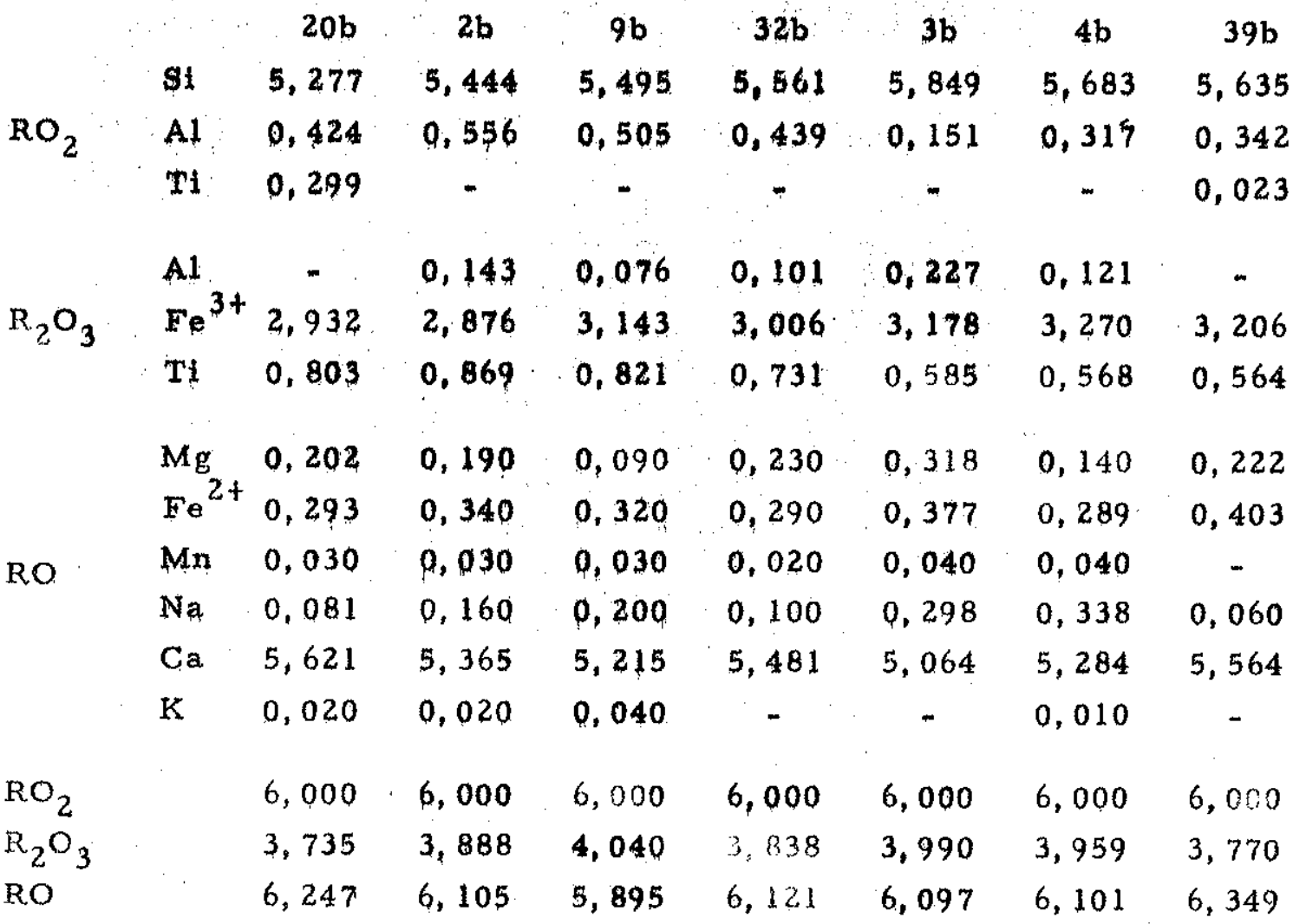

Porcentagem molecular

\begin{tabular}{lrrrrrrr} 
Andradita & 91,4 & 90,6 & 92,2 & 91,0 & 89,8 & 91,8 & $89,9^{*}$ \\
Piropo & 3,3 & 3,2 & 1,6 & 3,8 & 2,8 & 2,4 & $3,6^{*}$ \\
Almandina & 4,8 & 5,7 & 5,7 & 4,8 & 6,7 & 5,0 & $6,5^{*}$ \\
Espessartita & 0,5 & 0,5 & 0,5 & 0,4 & 0,7 & 0,7 & - \\
\multicolumn{7}{c}{ Propriedades } & f 5 sicas \\
n & 1,905 & 1,900 & 1,900 & 1,890 & 1,890 & 1,895 & 1,895 \\
D & 3,766 & 3,737 & 3,762 & 3,785 & 3,713 & 3,745 & 3,720 \\
a. (A) & 12,095 & 12,082 & 12,077 & 12,086 & 12,065 & 12,064 & 12,066
\end{tabular}

* Poicentagens (Andradita $=91,5 ;$ Piropo $=5,5$ e Almandina $=3,0$ ) calcu lada em função da quantidade de alumina disponível. 
Lisadas (Am. 20b e 39b) quando então ocupa, em ordem, cêrca de 5 e $0,4 \%$ do grupo referido. A presença de $\mathrm{Ti}$ no grupo de $\mathrm{RO}_{2}$, amostra $20 \mathrm{~b}$, pode ser atribuída ao elevado teor de titânio do mineral, enquanto que na amostra $\underline{39 \mathrm{~b}}$ parece decorrer mais do seu baixo teor em Al.

As propriedades físicas determinadas dão para êsses minerais os valores extremos seguintes: $\underline{n}=1,890$ e $1,905, \quad \underline{D}=$ $=3,713$ a 3,785 e $\mathrm{a}_{\mathrm{o}}=12,064$ a 12,095 (Tabela IV).

Foram feitas tentativas com o proposíu de correla cionar o conteúdo de titânio dessas granadas com as suas constantes físicas $\underline{n}$, D e $a_{0}$. As relações encontradas para o Índice de refração e pêso específico não permitiram que se extraissem quaisquer informações, todavia, o mesmo não sucedeu com a referente ao paráme tro da cela unitária. A conclusão obtida a partir do diagrama da Fig, 8,

\section{TABELA $X$}

Composição químic a (elementos traços) de granad as

\begin{tabular}{lrr} 
ppm & \multicolumn{1}{c}{1} & \multicolumn{1}{c}{2} \\
$\mathrm{Ga}$ & 22 & 10 \\
$\mathrm{Cr}$ & 18 & 10 \\
$\mathrm{~V}$ & 817 & 2000 \\
$\mathrm{Nb}$ & 345 & 200 \\
$\mathrm{Ni}$ & 41 & 10 \\
$\mathrm{Co}$ & $\mathrm{nd}$ & 10 \\
$\mathrm{Cu}$ & 6 & 30 \\
$\mathrm{Sc}$ & 16 & 20 \\
$\mathrm{Zr}$ & 2520 & 1500 \\
$\mathrm{Y}$ & 418 & 300 \\
$\mathrm{Sr}$ & 176 & 2000 \\
$\mathrm{~Pb}$ & 17 & 0 \\
$\mathrm{Ba}$ & 60 & 200
\end{tabular}

1. Média de 7 análises. Itapirapua.

2. Média de 11 análises. Magnet Cove, Arkansas, E. U.A. (Erickson e Blade, 1963, p.66). 


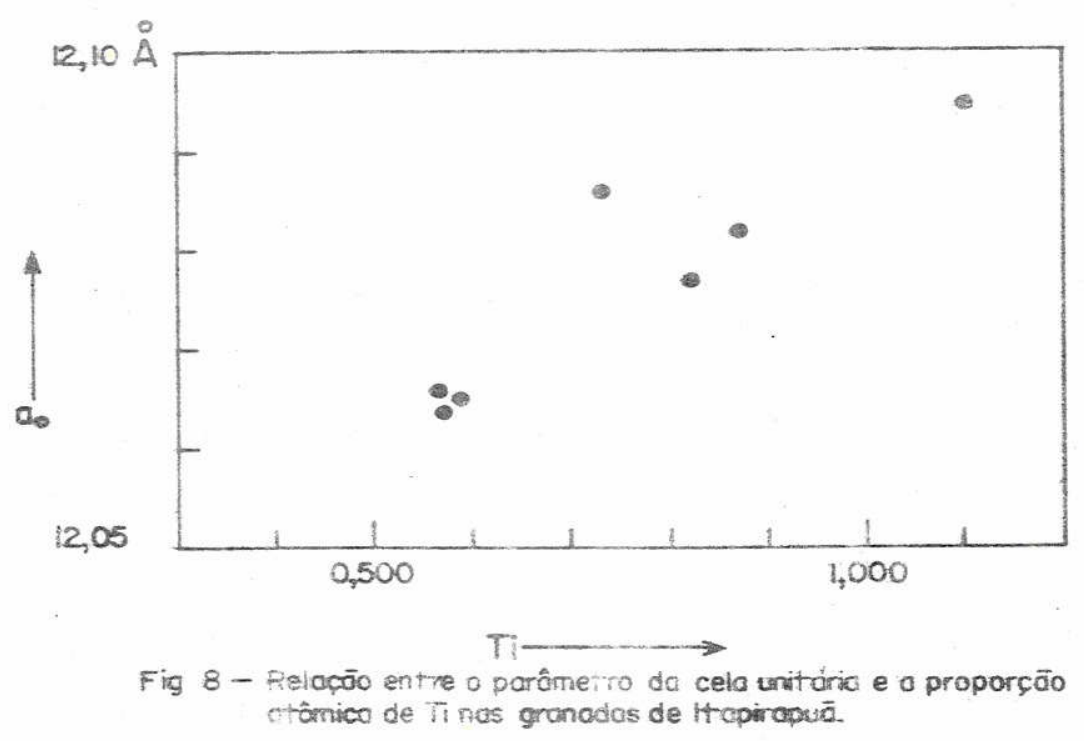


indicando que $a_{0}$ e titânio comportam-se nesses minerais como va riáveis diretamente proporcionais, é idêntica àquela, preliminarmen te alcançada por Zedlitz (1.933, p.236) e, mais tarde, por êle mesmo confirmada (Zedlitz, 1935, p. 71) em estudo mais completo sôbre o as sunto.

Quanto à espectrografia, nota-se que os diversos exemplares analisados não mostram, entre si, variações marcantes para quaisquer dos elementos traços pesquisados (Tabela VIII). Con tudo, o exame dos dados obtidos permite, de imediato, destacar os teores elevados em. V, Sc, Nb, Zr e Y dêsses minerais. Um quadro comparativo, contendo as composições médias das 7 amostras de Itapirapuã e de 11 da província de Magnet Cove nos Estados Unidos da A mérica, é dado na Tabela X e os resultados indicam que as primeiras se apresentam mais enriquecidas em $\mathrm{Zr}, \mathrm{Nb}$ e $\mathrm{Y}$ e menos em $\mathrm{V}, \mathrm{S} r$ e Ba.

\section{Outros minerais acidentais}

Ao lado dos piroxênios e granadas tratados ante riormente, serão descritos ainda como constituintes acidentais des sas rochas os seguintes minerais: biotita, wollastonita, pectolita, fluo rita, eucolita, pirita, pirrotita e calcita, além dos minerais $\underline{A}$ e B . ambos de natureza desconhecida (ver Tabelas Ia e Ib).

\section{Biotita}

Biotita ocorre nas variedades litológicas de Itapira puã (ver Tabelas Ia e Ib), ora na matriz equigranular das rochas de granulação média, ora formando fenocristais $(1,10-1,80 \mathrm{~mm})$ em matriz de granulação fina $(0,15-0,30 \mathrm{~mm})$, caso particular das armos tras 1 e 8 , quando então chega a alcançar até $7 \%$ da moda. Macroscò picamente, a côr é escura e, quando presente como fenocristal, o mìneral exibe hábito placóide com contornos aproximadamente hexago nais. Ao microscópio, ostenta forte pleocroísmo com X (amarelo-alaranjado) $\quad \mathrm{Y}=\mathrm{Z}$ (castanho escuro). Os resultados obtidos para o Índi.. ce de refração $N_{z}$ das amostras $\underline{1}$ e 8 foram, respectivamente, 1,643 e 1,655. O ângulo axial dêsses minerais varia entre os seguintes valo 
res: $2 \mathrm{~V}(-)=22^{\circ}$ e $2 \mathrm{~V}(-)=17^{\circ}$. Parece tratar-se, a julgar pelo acen tuado pleocroísmo, da variedade titanífera de biotita, descrita como wodanita por Troger (1956, p. 82).

Wollastonita

Wollastonita foi reconhecida tão sòmente na amos tra 20 , onde representa $8,4 \%$ de seu volume. O mineral tem häbito taw bular paralelo à face (100) e alongado segundo o eixo cristalográficob. Macroscòpicamente a côr é branca e microscòpicamente incolor: o tamanho dos constituintes situa-se ao redor de $0,90 \mathrm{~mm}$. Geminação múltipla segundo (100) é muito comum. Suas constantes ópticas são $\mathrm{N}_{\mathrm{x}}=1,618, \mathrm{~N}_{\mathrm{y}}=1,630$ e $\mathrm{N}_{\mathrm{z}}=1,632 ; 2 \mathrm{~V}(-)=37^{\circ}$ e $\mathrm{N}_{\mathrm{z}}-\mathrm{N}_{\mathrm{x}}=0,014$. Por êstes dados e de acôrdo com o diagrama de variação de Bowen et al. (1933), que relaciona índices de refração com as percentagens das moléculas de $\mathrm{CaSiO}_{3}$ e $\mathrm{FeSiO}_{3}$, verifica-se que o mineral em questão é, pràticamente, wollastonita pura.

Pectolita

Pectolita foi identificada ao microscópio numa única rocha da província - um nefelina sienito de granulação muito fina (Am. 10) - e ocupa 4,3\% do seu volume. Parece também estar presente na amostra 5. O mineral é incolor e tem hábito acicular, alongado segundo b. Comumente se dispõe em arranjos radiais, com o comprimento dos indivíduos não indo além de 0,15 mm. Foi observada geminação (100) em alguns cristais. Algumas de suas propriedades ópticas foram determinadas e os valores obtidos são os seguintes: $N_{z}=1,635$ e $2 \mathrm{~V}(t)=$ $=55^{\circ}$.

Fluorita

Fluorita está presente em alguns nefelina sienitos da província na forma de grânulos isolados, ou então, em pequenos agrega dos prontamente reconhecíveis microscòpicamente em razão do seu caráter isotrópico, relêvo negativo e, sobretudo, de sua coloração violeta. em manchas. 


\section{Eucolita}

Eucolita foi reconhecida nas rochas de Itapirapuã, única e exclusivamente, ao longo de um pequeno veio cortando a amos.. tra 13. A vista desarmada, exibe côr vermelho característica; em sec ção delgada, contudo, mostra-se levemente róseo até incolor. Ocorre na forma de pequenos cristais, aproximadamente equidimensionais, ten do como principal feição distintiva fraco pleocroísmo com 0 (carmim)

E (pardo-amarelado a incolor). Alguns cristais são zonados。O mï. neral é uniaxial negativo e os seus índices de refração e birrefringência são os seguintes: $N_{0}=1,641, N_{e}=1,631$ e $N_{0}-N_{e}=0,010$. Estes valores correspondem à variedade eucolita da série eudialita-eucolita. de Tr8ger (1956, p.23)。

Pirita

Pirita ocorre em algumas rochas tinguaiticas da pro víncia (entre outras na amostra 19) na forma de pequenos cristais cúbi. cos, de côx amarelo e dimensões milimétricas. Sua presença parece estar ligada a processos de alteração hidrotermal. É visível mesmo à vista desarmada.

Pirrotita.

Pirrotita foi vista tão somente nas amostras de car bonatito quando aparece em cristais informes, de cốr amarelo-bronzea do caracteristica.

Calcita

Calcita, nas amostras estudadas e na condição de mineral de cristalização tardia, ocorre apenas nos carbonatitos da pro víncia. Nestas rochas, o mineral é granular, de côr branco a brancoacinzentado, em dimensões varíáveis desde 1,5 a $3,0 \mathrm{~mm}$. Ao micros cópio é xenomórfíco e, frequentemente, portador de geminação múlti pla segundo (0112). Os índices de refração medidos são $\mathrm{N}_{0}=1,661$ a. 1. 665, o que equivale dizer, de acőrdo com o diagrama de variação de 
Kennedy (1.947, p.561), que se trata, pràticamente, de calcita pura. Processos de coloração ("staining"), por meio de ensaios químícos, demonstraram, em concordância com o exame óptico, que calcíta é - único mineral carbonático dessas rochas.

Mineral A

Mineral A foi observado sempre em porcentagens diminutas, em algumas variedades petrográficas do maciço. Apresenta hábito alongado, comumente formas prismáticas regulaxes e compri mento máximo de $0,5 \mathrm{~mm}$ (Fotomicrografia 5). Foram reconhecidas duas direções de clivagem, sendo uma paralela e a outra transversal ao seu alongamento. A côr, ao microscópio, varia de verde-amarela do a amarelo levemente esverdeado; o relêvo é alto, a birrefringencia baixa e a côr de interferência anômala, em tonalidades azul. a cinzaazulado. O mineral é biaxial positivo; o ângulo entre os eixos óptícos é moderado e a extinção é inclinada, $\mathrm{X}$ vibrandó no sentido do alonga mento. Secções rômbicas foram reconhecidas e geminação simples é comum. A julgar pelas relações exibidas com os demais constituintes primários da rocha parece pertencer à última fase de cristalização.

Mineral B

Mineral B, presente na forma de uns poucos grânuLos disseminados na rocha, foi encontrado na província, única e exclusivamente, na amostra 23 (Fotomicrografia 6). Apresenta forma alon gada, com clivagem paralela ao seu alongamento e pleocroísmo perceptível, nas côres verde-amarelado e amarelo-esverdeado, observadas, respectivamente, ao longo e a $90^{\circ}$ do seu alongamento. O relêvo é alto, - mesmo sucedendo com a birrefringência. O mineral é biaxiall negativo, $2 \mathrm{~V}$ grande e o plano dos eixos ópticos paralelo à direção de clivagem. A elongação é negativa e a dispersão fraca com $v>r$.

Minerais acessórios e de alteração

Magnetita

Magnetíta é o acessório maís importante das rochas 
alcalinas de Itapirapuã e sua presença foi também notada nos carbona titos da província. Nos vários exemplares examinados, aparece sem pre em quantidades pequenas, não superior a 3,6\% da moda, e comu mente na forma de cristais idiomórficos de reduzido tamanho. Na ex tremidade sul do maciço, contudo, êsses cristais têm dimensōes centimétricas e, em geral, exibem hábito octaédrico bem desenvolvido. Nesta parte do corpo da rocha, o mineral se concentrou em grandes quantidades, dando como produto final massa compacta de 215.700 to. neladas de minério de ferro e que hoje vem sendo explorado comercial mente. Análises químicas (Passos Guimarães, 1960) acusaram valores de $\mathrm{Fe}_{2} \mathrm{O}_{3}$ (todo o ferro está expresso na forma trivalente) variáveís de 92,1 a $94,6 \%$ para amostras médias representativis de 2.500 tonela das de minério. As impurezas encontradas for am $\mathrm{Al}_{2} \mathrm{O}_{3}$ e $\mathrm{TiO}_{2}$ e, em menor quantidade, $\mathrm{SiO}_{2}$ e $\mathrm{P}_{2} \mathrm{O}_{5}$. Estes dados permitiram ao referido Autor concluir que magnetita contendo baixa porcentagem da moléculla de titanomagnetita é o constituinte proeminente dêsse depósito mineral. Apatita, presente em quantidade mínima, é o principal mineral a ela. associada. Têm sido observados em algumas partes do corpo de minério e, em particular, nas imediações de zonas de fraturas produtos de alt eração da magnetita, representados provàvelmente por material de natureza limonítica. A associação de corpos de magnetita à rochas eruptivas alcalinas já é de há algum tempo conhecída na liter atura geo lógica graças ao trabalho realizado por Leinz (1940) na região de Ipanema, SP.

\section{Titanita}

Titanita, na quase totalidade das rochas examina das, é o acessóxio mais abundante. Em algumas delas, caso especial das amostras 1 e 2 , sua quantidade é expressiva, chegando mesmo a alcançar até $5,4 \%$ da moda. O mineral é idiomórfico, exibindo ao mí.croscópio coloração parda, em tonalídades claras e escuras. Foram observadas secções rômbicas características em número apreciável de lâminas. Frequentemente, ocorre como cristal isolado, contudo, por vêzes, aparece na forma de pequenos agregados em assocíação com ou tros minerais, sobretudo, com pïroxênios e com granadas. 
Apatita

Apatita é acessório constante das rochas de Itapirapuã, onde chega a perfazer, com exceção dos carbonatitos, até cêrca de $2,2 \%$ da composição modal (Am. 1 ). Comumente, ocorre como grânulos isolados, em geral límpidos, arredondados e de dimensões reduzidas. Todavia, nos carbonatitos, apresenta-se na forma de pequenos agregados e com porcentagem modal, no caso particular da amostra C $-4 \mathrm{c}$, de $19,4 \%$ da rocha (Tabela XX). Os índices de refração determi nados em exemplar extraído desta amostra deram os seguintes valores: $\mathrm{N}_{\mathrm{o}}=1,633$ e $\mathrm{N}_{\mathrm{e}}=1,630$; birrefringência $\mathrm{N}_{\mathrm{o}}-\mathrm{N}_{\mathrm{e}}=0,003$. Éstes dados indicam (cf. Troger, 1956, p.27) tratar-se de uma flúor-apatita co mum.

Como constituintes secundários foram reconhecidos, ao lado dos produtos de decomposição da nefelina descritos anteriormente, os seguintes minerais: calcita, zeólitas, sericita, clorita e o mineral $\underline{C}$, de natureza ainda desconhecida.

\section{Calcita}

Calcita, como produto de alteração, está presente nessas rochas na forma de constituinte isolado, ou então, na condição de componente do agregado mineralógico resultante da decomposição da nefelina. No primeiro caso, é xenomórfica e sucontra-se sempre preenchendo fraturas e espaços intergranulares. Em geral, parece ter-se originado às expensas dos minerais ferromagnesianos, a saber, piroxênios e granadas e, subordinadamente, nefelina. Como integrante do agregado, o reconhecimento da calcita ao microscópio nem sempre é possível, face à granulação muito fina e ao aspecto sujo e granulado do conjunto.

\section{Zeólitas}

Zeólitas, representados por natrólita e/ou thomsonita, são encontrados em algumas variedades litológicas do distrito na forma de agregados fibrorradiais. Excepcionalmente, é o caso espe cial da amostra 40 , podem ocupar até $14,9 \%$ de seu volume. A imprati.. 
cabilidade de melhor caracterização decorre da presença de impure zas, provàvelmente de natureza limonítica, nêles disseminadas.

Sericita e Clorita

Sericita e clorita ocorrem na forma de minúsculas palhetas; contudo, enquanto o primeiro associa-se aos feldspatos, dos quais provém, ocupando indistintamente as partes centrais e periféri cas dos cristais, o segundo está ligado întimamente aos cristais de pí roxênios, sendo em geral encontrado em suas bordas.

\section{Mineral. C}

Mineral C, de hábito fibroso e pardacento, é ob servado em algumas rochas da região. E, provàvelmente, de natureza secundária, visto que em tôdas as lâminas onde foi reconhecido en contra-se ao lado de minerais de alteração e, em especial, daqueles resultantes da decomposição da nefelina.

$$
\text { Seqǘência de cristalização }
$$

Feldspatóides

A nefelina se cristalizou cêdo em tôdas as variedades petrográficas da província, quer na forma de fenocristais, caso dos tinguaítos e também de outras rochas de granulação fina, quer como componente de sua matrịz. Nos estádios finais de cristalização o mineral foi em geral substituído por cancrinita. Sodalita aparece como mineral tardio e em raras rochas da região. Sua presença está ligada invariàvelmente a cristais de nefelina, dos quais se originou.

Feldspatos

A ausência de dados químicos, aliada às dificulda des de determinação da composição dos feldspatos alcalinos a partir de constantes ópticas, tornam problemáticas quaisquer conclusões a respeito do curso de cristalização. Não obstante, tentou-se investi - 
gar o comportamento dêsses minerais valendo-se das porcentagens normativas das moléculas de $\mathrm{Ab}$, An e Or das várias rochas da provín cia. As deduções tiradas, se bem que revelando apenas tendências gerais, parecem apontar no sentido de um enriquecimento da fase sódi ca nos estádios finais de cristalização dêsses minerais. Tal assertiva parece concordar com as variações ópticas encontradas, dando aos feldspatos das rochas tinguaíticas valores mais altos para o ângulo en tre os eixos ópticos e, conseqtentemente, porcentagem mais elevada da molécula de Ab, segundo o diagrama de variação de Tuttle (1952).

\section{Piroxênios}

As variações ópticas observadas em cristais zonados de piroxênios, refletindo a composição mais augítica do núcleo dês ses indivíduos e a maior riqueza na molécula de Eg em suas partes marginais, guardam concordância com as sucessivas modificações quí micas que teriam se verificado no decurso da cristalização. Os dados químicos disponíveis, obtidos de 10 análises químicas dêsses mine rais, e as informações ópticas coligidas, indicam claramehte que, nas rochas alcalinas de Itapirapuã, a cristalização dos piroxênios pro cessou-se na seguinte seqtência: soda:augita $\longrightarrow$ egirina-augita $\rightarrow$ egi rina, O gráfico da Fig. 9, que relaciona a molécula de Eg dos piroxênios, expressa pelo número de íons de $\mathrm{Fe}^{3+}$ por fórmula unitária, e suas constantes ópticas, mostra a sucessão dos diferentes têrmos da série. Observa-se neste diagrama que o índice de refração $\left(N_{y}\right)$, o ân gulo de máxima extinção inclinada $(\mathrm{X}: \mathrm{c})$ e o $2 \mathrm{~V}$ variam linearmente. de $\mathrm{Fe}=\mathrm{Fe}^{2+}+\mathrm{Fe}^{3+}+\mathrm{Mn}$ - pode ser acompanhada na curva 1 da Fig. 10, ao lado de curvas correspondentes aos piroxênios da intrusão de Skaergaard (Brown, 1957; Brown e Vincent, 1963) e rochas alcalinas do distrito de Morotu, Sakhalin (Yagi, 1953). De imediato chama a atenção, o comportamento discordante dos piroxênios das rochas calco -alcalinas e alcalinas, variando êstes últimos no sentido de maior en riquecimento em $\mathrm{Fe}$, em detrimento de $\mathrm{Ca}$ e $\mathrm{Mg}$. Os piroxênios das ró chas de Itapirapuã, todos projetados abaixo da linha diopsídio-hedenber gita, têm o curso evolutivo, em seus estádios iniciais, quase paralelo à essa linha, passando dos têrmos mais ricos aos mais pobres na mo- 


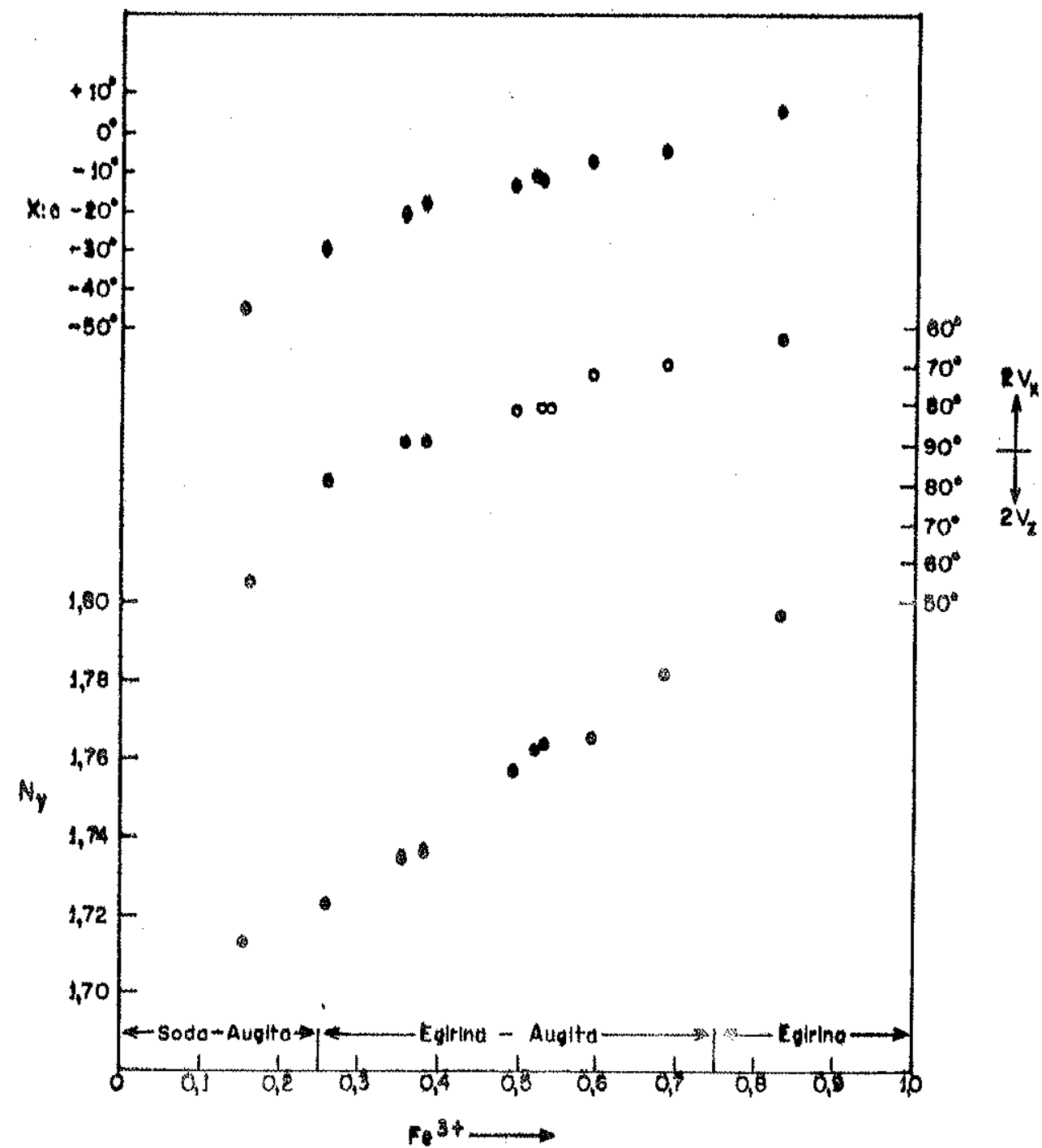

Fig. -ord́fico relacionando a molécula de Eglina com as propriedades ofticas dos verios termos do série dos piroxênios de ltaplrapul. 

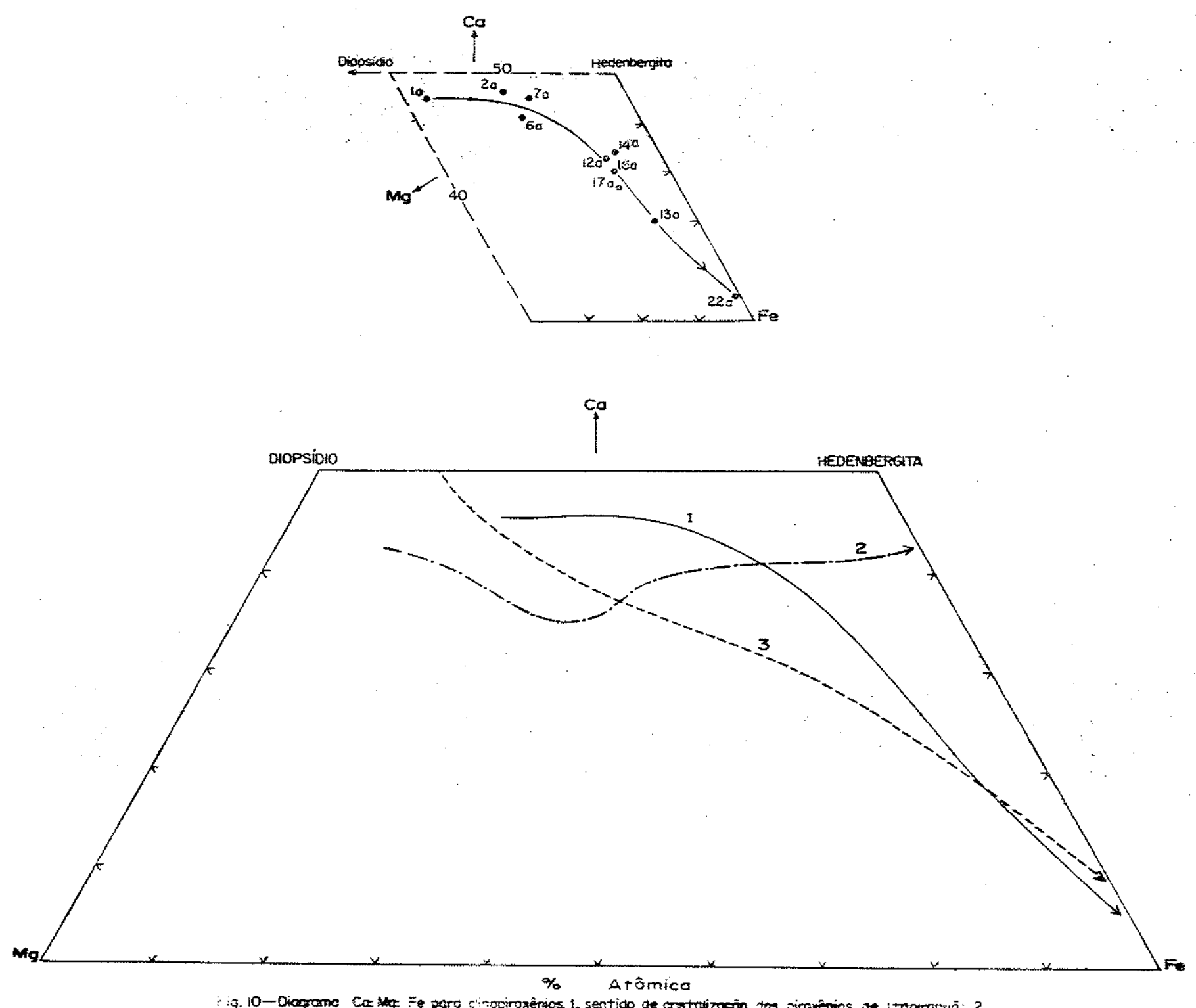

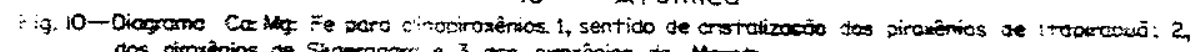


lécula de Di. Após esta fase, exibem enriquecimento pronunciado em $\mathrm{Fe}$ e, em contrapartida, empobrecimento em Ca e mais ainda em $\mathrm{Mg}$, culminando na série com um membro quase desprovido de magnésio.

Apreciação mais completa da sequência evolutiva dêsses piroxênios é conseguida com a curva 1 do diagrama triangular NatK:Mg:Fe da Fig. 11. Nêle a molécula de Ac, que desempenha pa pel importante no estádio final da cristalização, é representada pelo vértice $\mathrm{Na}+\mathrm{K}$. Além das curvas dos piroxênios de Itapirapuã, de Skaergaard e Morotu, constam também dêsse diagrama os campos de com posição de clinopiroxênios sódicos (campo A) e cálcicos (campo B) es tabelecidos por Aoki (1964, p. 1210) e, separando-os uma extensa re gião de imiscibilidade sob condições ígneas (campo C). A anảlise da Fig. 11 permite concluir que o curso de cristalização dos pirroxênios das rochas calco-alcalinas de Skaergaard (curva 2) é bem distinto dos demais, efetuando-se totalmente dentro do campo de variação dos pi roxênios cálcicos. Nota-se também que as curvas indicando o sentido de cristalização dos piroxênios das rochas alcalinas, têm comportan mento muito similar, parecendo que as pequenas deflexões apresen tadas redundam, principalmente de diferenças nos teores em FeO.

Os piroxênios, objeto dêste estudo, ocupam duas zonas distintas dentro do diagrama triangular $\mathrm{Na}+\mathrm{K}: \mathrm{Mg}: \mathrm{Fe}$ 。 $\mathrm{Na}$ pri meira (campo C), correspondendo à região de imiscibilidade, estão concentrados a soda-augita (Am, la ) e três exemplares portadores de baixa porcentagem da molécula de Ac (Am, 2a, 6a, e 7a), enquan to que na segunda (campo A), área de composição dos piroxênios sódilcos, situam-se as demais amostras investigadas. As relações exĭ. tentes entre os membros sucessivos da série, evidenciadas pelo seu curso de cristalização e pelos dados ópticos obtidos, indicam que ês ses minerais formam solução sólida contínua. A existêncía de solu ção sólida entre clinopiroxênios ricos em Ca-Mg e ricos em Na-Fe $\mathrm{Fe}^{3+}$ foi primeiramente suspeitada por Vogt (1924) e mais tarde confirmam da por Yagi (1958 e 1962), graças a estudos experimentais levados a efeito no sistema binário acmita-diopsídio. Mais recentemente, Yagi (1966) divulgou resultados de estudos sôbre equilibrio de fases neste sistema, com especial referência à estabilidade de egirinas e/ou egì rina-augitas naturais, colocando em dúvida a existência da regĩa de Imiscibilidade de Aoki (1964), não evidenciada no intervalo de tempe 


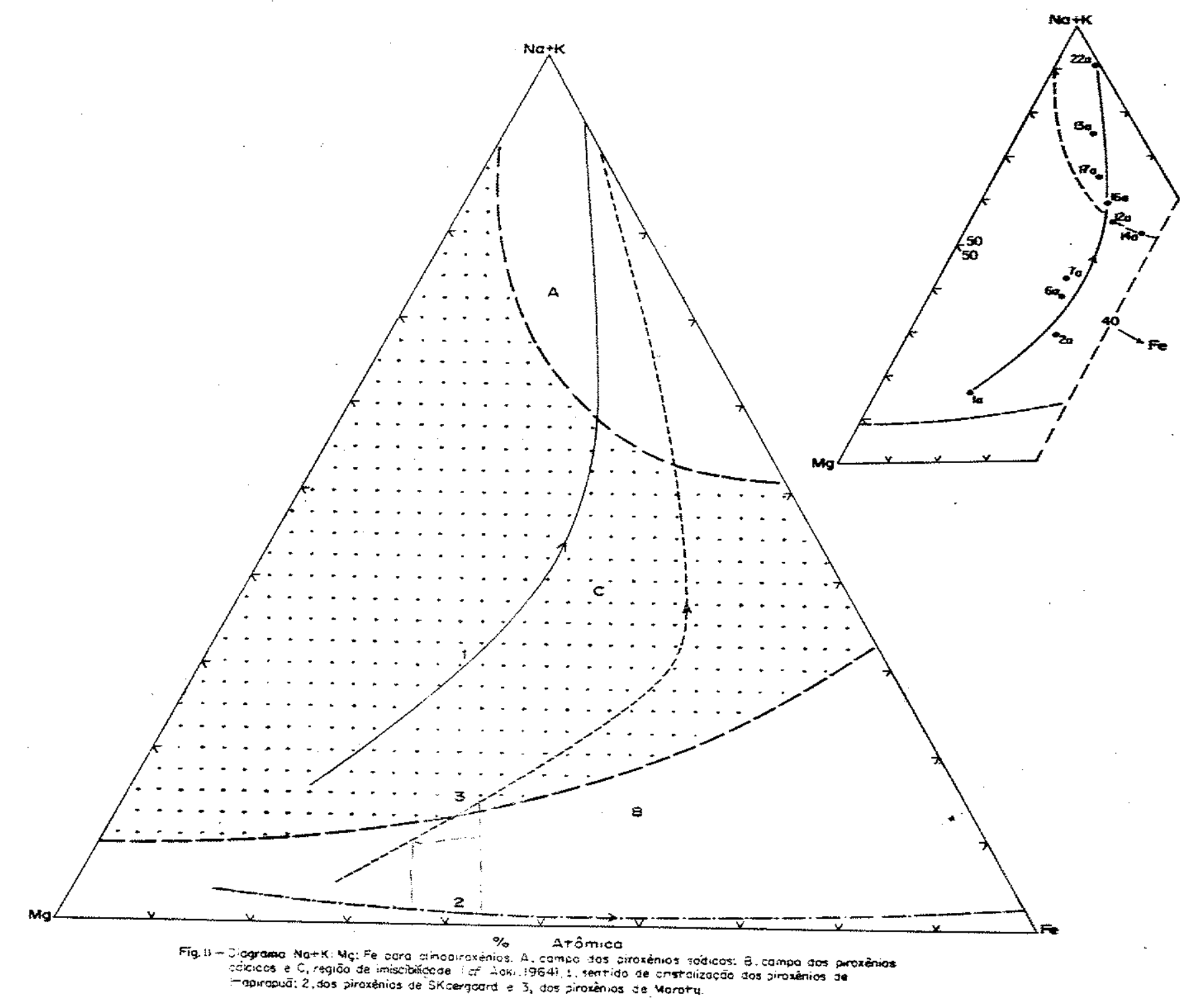


ratura estudado。

$\mathrm{O}$ grupo $\mathrm{Z}$ dos clinopiroxênios investigados (ver $\mathrm{Ta}$ bela VI) é ocupado por Si e Al IV à exceção de dois membros da sé rie (Am. 13a e 22a), onde Ti está presente nas porcentagens de 0,9 e 1,6. Contudo, as proporções de $\mathrm{Al}^{\mathrm{IV}}$ são variáveis, alcançando valor máximo $(6,1 \%)$ na amostra la de soda-augita. O papel desempe nhado por $\mathrm{Al}^{\mathrm{IV}}$ e Ti no grupo $\mathrm{Z}$ dos clinopiroxênios de rochas ígneas tem despertado a atenção de vários pesquisadores, merecendo destaque especial os trabalhos executados por Kushiro (1960) e Le Bas (1962). Estes Autores, baseando-se em dados estatísticos, concluí ram que os piroxênios estudados em rochas traquíticas e basálticas alcalinas têm maior proporção de alumina (Al ${ }^{\mathrm{IV}}$ ) na posição tetraé drica estrutural do que os correspondentes minerais da série toleituca calco-alcalina e que a proporção dêste elemento decresce durante o processo de cristalização magmática. Lamentàvelmente, porém , os piroxênios sódicos for am omitidos dêsses trabalhos. Todavia, em face das considexações teóricas formuladas por Kushiro (1960, pp. 552-553) sôbre os fatôres que controlam a substituịção Si-Al, bus cou-se encontrar uma relação entre essas variáveis para os piroxê nios aqui estudados, sendo o diagrama da Fig. 12 o resultado dessa tentatîva. Neste, verifica-se que a concentração de Si nos pirroxênios investigados aumenta corn o curso de cristalização, enquanto que o conteúdo de Al total, cresce em sentido oposto. Esta conclusão é cain cidente com a observada na cristalização dos piroxênios das intru sões magmáticas de Skaergaard (Brown, 1957: Brown e Vincent, 1963), Stillwater (Hess, 1949), Black Jack (Wilkinson, 1957) e Atumi (Kushiro, 1959). Já Al e Ti (totais), como demonstrado na Fig. 13, comportam-se como variáveis diretamente proporcionais. o crescimento da proporção de Ti com o aumento de Al totall (e mes mo de Al. ${ }^{\text {IV }}$ ) constitui., segundo Kushiro $(1960$, p. 550) e Le Bas (1962, p. 280), característica comum a rochas toleíticas e rochas al calinas trazendo ou não feldspatóides na composição. Ti ocupa a po sição estrutural $\mathrm{Z}$ dos piroxênios investigados ùnicamente $\mathrm{em}$ dois membros da série (Am. 13a e 22a) e a sua presença nesse grupo, de conformidade com Brown (1957, p. 518), parece decorrer nesses minerais muito mais do teor elevado em $\mathrm{Na}+\mathrm{K}$ que do conteüdo em titânio. 


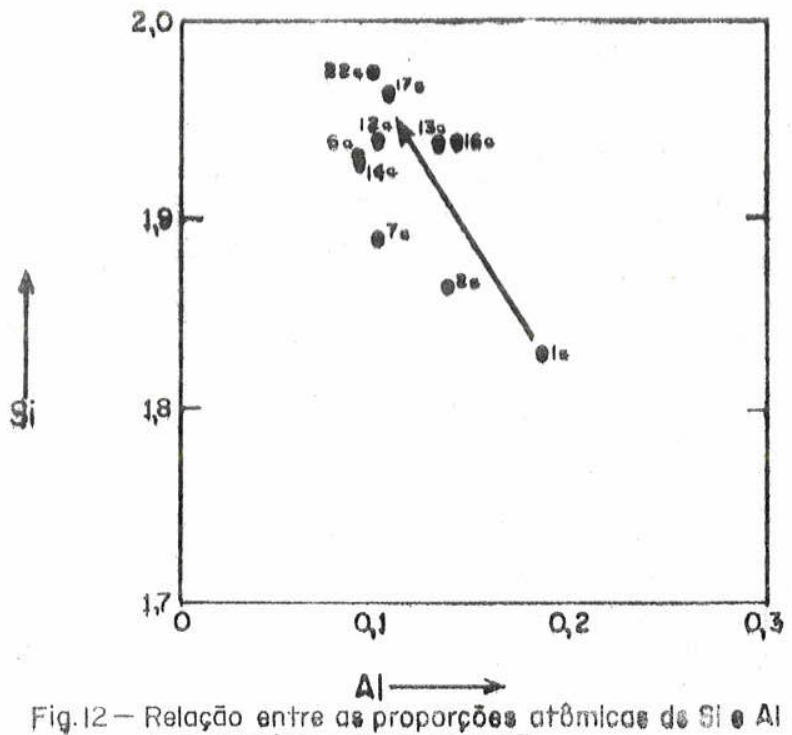
nos piroxênกios de Itapirapuă.

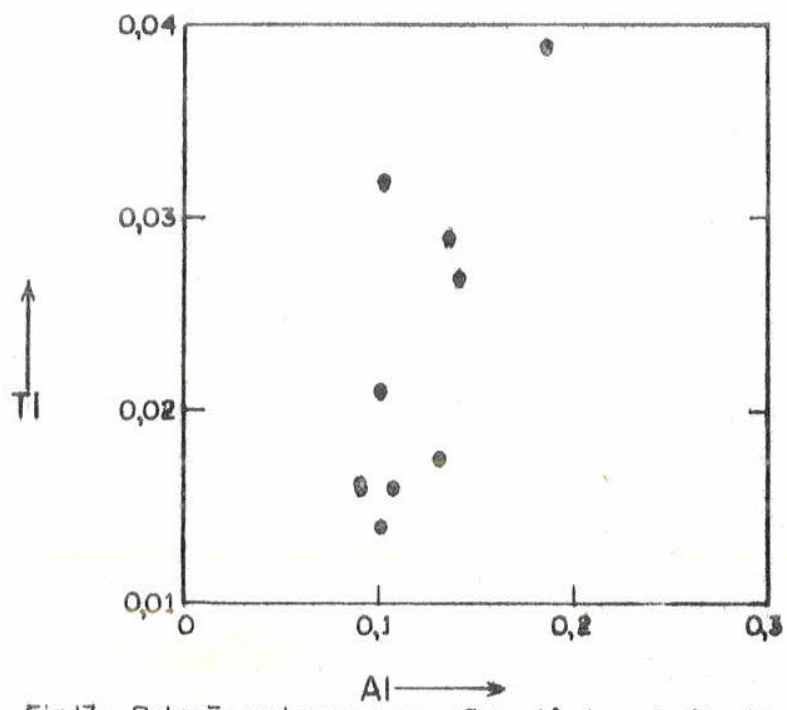

Fig.13 - Relaçāo entre as proporçöes atômicas de $\mathrm{Tl}$ • Al nos pirôxenios de Itapirapü̈. 
Variações regulares dos teores dos vários elemen tos traços nos componentes da série sòmente for am notadas para Zr, $\mathrm{Nb}$ e Sr e o gráfico da Fig. 14 indica que os dois primeiros elementos, $\mathrm{Z}$ r de forma mais convincente que $\mathrm{Nb}$, crescem diretamente com a porcentagem da molécula da Eg dêsses piroxênios. Já Sr se compor ta de maneira diversa a $\mathrm{Zr}$ e $\mathrm{Nb}$ e parece decrescer com o aumento dessa molécula (Fig. 15).

Granadas

As evidências texturais encontradas nas rochas nefelínicas portadoras de melanita parecem indicar que êstes minerais são de substituição, tendo-se formado principalmente às expensas de titanita e piroxênios. Conclusão análoga foỉ alcançada por King (1965, p.89) em estudo sôbre as rochas alcalinas, da série melteigị to-ijolito-urtito, existentes na parte oriental de Uganda. Variações na composição das granadas titaníferas for am observadas por êste Autor ao longo do seu curso de cristalização, levando, nos seu.s estádios fijnais, à transformação total de melanita em andradita. Ainda confor me King (1965, p. 89), esta sequência é evidenciada em secção delga da pela mudança de côr do mineral que passa de qua se opaco a casta.nho translúcido.

A existência de estrutura zonada nas melanitas de rochas de Itapirapuã levou-nos a estudar, o mais detidamente possí vel, o comportamento dêsses minerais com o propósito de estabele cer sua sequência de cristalização. Para isso, for am executadas 7 am nálises químicas, incluindo elementos traços, de exemplares minera lógicos extraídos de rochas da região. Os : resultados coligidos acham-se representados na Tabela VIII. Nesta, verifica-se que o teor de titânio decresce nos miner ais analisados de 8,72 a $4,49 \%$, no que é seguido por uma diminuição nos valores do parâmetro da cela uni tária de 12,095 a $12,064 \AA$ A. O exame das análises químicas obtídas parece indicar que a cristalização magmáticas dêsses mineraỉs processou-se, em traços gerai,s, de conformidade com o esquema deli-. neado acima, sem contudo, ter conduzido à formação de andradita. em sua fase final. Merece destaque, dentro da sucessão de mem . 


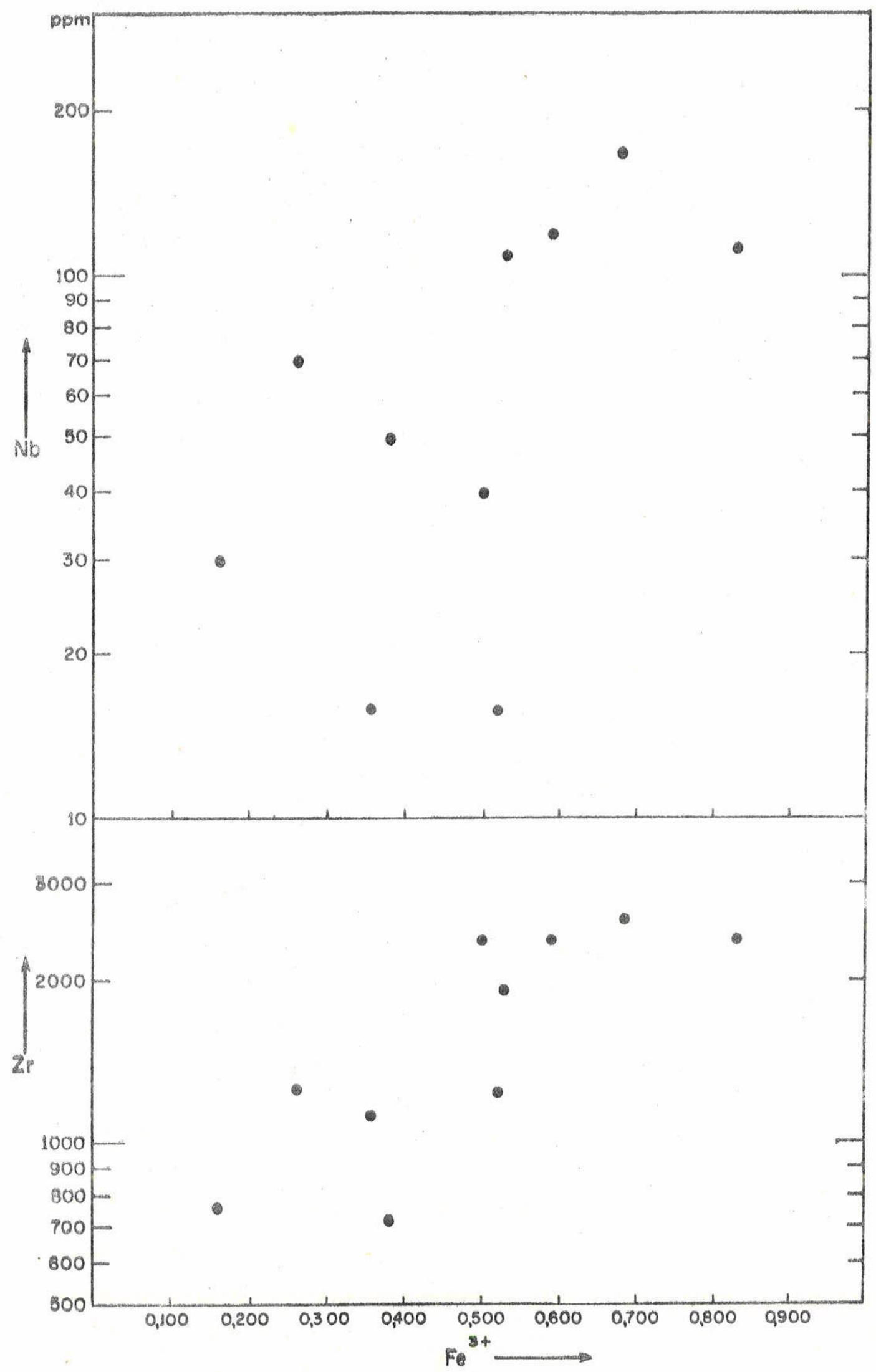

Fig.14-Grófico reunindo a molécula de Eglrina, expressa pola propopcáo atốnico de

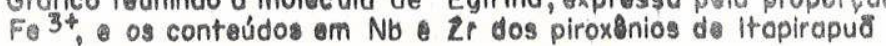




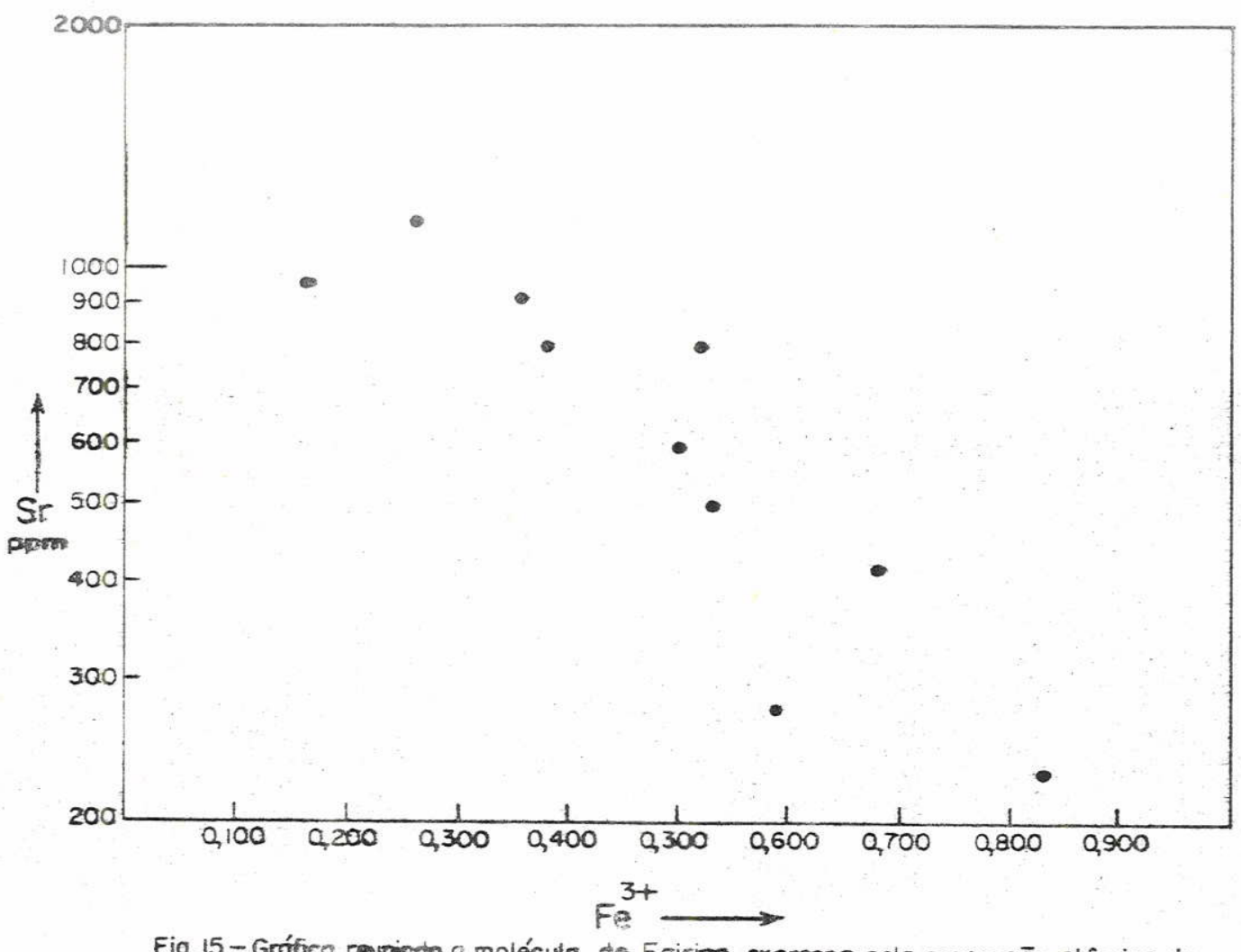

Fig. 15-Gráfico reurindo o moléculo de Egirina, expressa peta proporçāo atômica de $\mathrm{Fe}^{3+}$, e o conteúdo em $\mathrm{Sr}$ cos piraxênios de itapirapuā. 
$-58$.

bros dessa série, a amostra $32 \mathrm{~b}$, formada ao longo de veios cortan do as rochas nefelínicas, em razão do teor elevado em titânio. 


\title{
PETROGRAFIA
}

\author{
Introdução
}

No presente capítulo são estudadas as principais feições mineralógicas e texturais das variedades petrográficas do dis trito alcalino de Itapirapuã. Tendo em vista a melhor caracterização dêsses tipos litológịcos, procurou-se, sempre que possível, confron tá-los, sob o ponto de vista químico, com rochas semelhantes, re correndo-se, seja a análises individuais, seja a composições médias referidas na literatura. Os vários grupos de rochas serão descritos segundo a ordem adotada no mapa geológico da Fig. 3.

A definição adotada para rochas alcalinas é a de Shand (1943). Para a classificação petrográfica valeu-se sobretudo do sistema proposto por Johannsen (1939), procurando-se contudo, sem pre que possível, evitar o emprêgo de nomes raros e pouco utiliza dos na literatura. Com idêntico propósito, utilizou-se também o cri tério de classificação de rochas, com base em minerais-prefixos, re correndo-se para tanto aos seus constituintes acidentais.

O têrmo melteigito foi aplicado, no sentido pro posto por Brygger (1921), a uma rocha da série urtito-ijolito-meltei gito, contendo menos de $50 \%$ de nefelina ou de seus produtos de alteração. Empregou-se o têrmo malignito, dada a inexistência na lite ratura de alusão a um nome para unefelina sienito, portador de melanita, e contendo mais de $50 \%$, em volume, de minerais ferro magnesianos e cuja relação feldspatos:feldspatóides é de aproxima damente 14:86. Esta designação não confere estritamente com a de finição adotada por Johannsen (1939), mas se acomoda a várias ou. tras encontradas na literatura.

Para a classificação dos carbonatitos, adoţ́心iłse a. nomenclatura proposta por von Eckermann (1948, p. 13), recorren do-se aos minerais-prefixos quando os constituintes não-carbonáti cos estão presentes nas rochas em quantidade superior a $10 \%$.

Ao processo de alter ação metassomática das encaixantes por efeito de intrusões alcalinas, usou-se a expressão fe-nitização, empregada por Brłgger (1921, p. 17). Os produtos resul tantes de Itapirapuã, embora apresentando várias evidências de te - 
rem sido submetidos à ação dêsse processo, têm composição quími ca e mineralógica diferentes das exibidas pelos fenitos daquele Autor, razão pela qual se optou pelo emprêgo da expressão fenitizado, acres cida ao têrmo litológico, para melhor caracterizá-los petrogràfica mente。

Com o objetivo de facilitar a leitura dêste traba . 1ho, aos não familiarizados com a nomenclatura das rochas alcali nas, elaborou-se, a exemplo de von Eckermann (1948, pp.14-15) dois diagramas (Fig. 16) em que a composição das rochas expressas pelas porcentagens em pêso dos seus principais constituintes minerais, é dada de forma esquemática. Deve ser frisado, entretanto, de con formidade com aquêle Autor, que as linhas retas ao longo das quais se processa a gradação de uma determinada associação mineralógi ca à sua vỉzinha têm um sentido puramente esquemático, não repre sentando qualquer limite de diferentes fases mineralógícas. Frise - se igualmente, que nenhuma secção dos diagramas constitui obriga tôriamente uma composição de rocha observada.

\section{Metodologia}

Tôdas as amostras coletadas no interior do cor po alcalino foram examinadas ao microscópio, num total aproxima do de 120 secções delgadas.

As rochas analisadas quîmicamente, em número de 24, tiveram seus pêsos específicos determinados com o auxílio do densímetro de Stbe, de conformidade com o procedimento descrito por La Touche (1908, p. 21).

As análises modais, em número de 38, for am calculadas pelo método do contador de pontos (Chayes, 1949), sendo os totais de pontos obtidos em cada secção delgada superiores a 1000 , na quase totalidade das amostras estudadas, Os resultados alcança dos, como já referido no capítulo anterior, estão contidos nas Tabe las Ia e Ib e expressos em porcentagens volumétricas. As amostras 18 e 19, relativas aos tinguaítos analisados quîmicamente, não tive ram calculadas suas modas em razão da granulação finíssima des sas rochas.

As normas moleculares for am calculadas pelo mé 


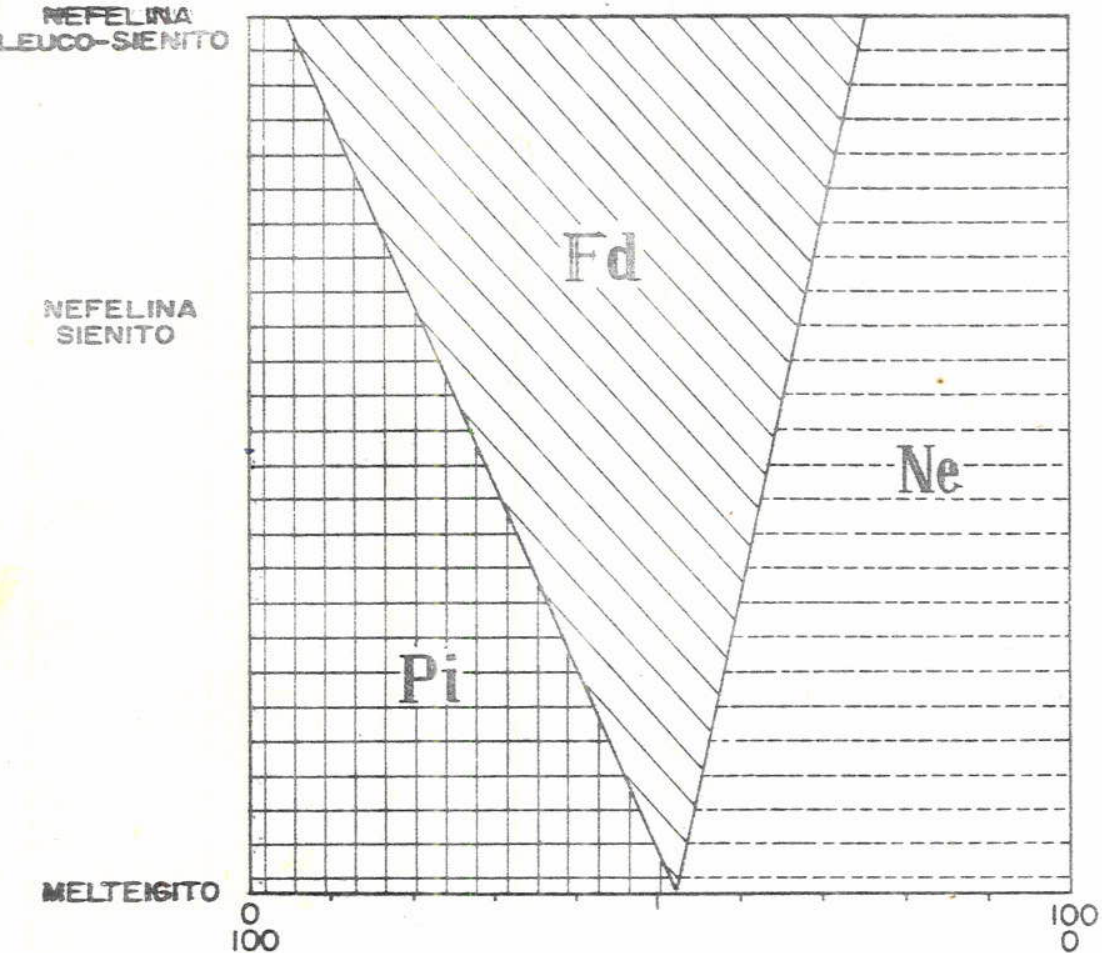

\begin{tabular}{|c|c|c|c|}
\hline -Nēe & $\begin{array}{l}\text { NEFEL NA EPRODUTOS } \\
\text { OE ALTERACÃO }\end{array}$ & Me & MELANITA \\
\hline & FELDSPATOS & & WOLLASTUMITA \\
\hline & PHTOXÊMOS & B & BIOTITA \\
\hline
\end{tabular}

Fig.16- Dicgrano de nomentictura.

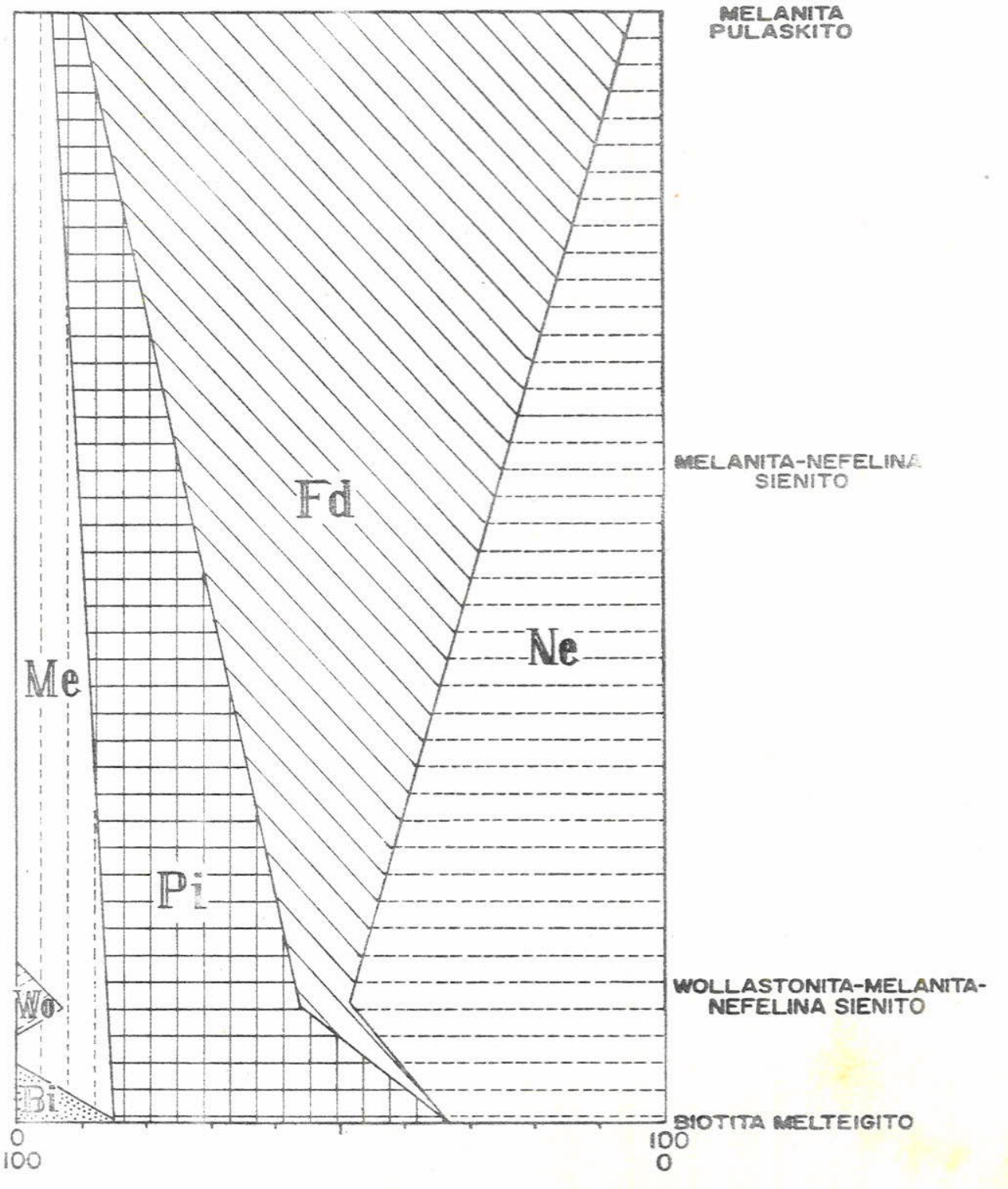


todo CIPW, condensado em Johannsen (1939, I, pp.83-99), optando-se pela formação de calcita em lugar de cancrinita para tôdas as rochas portadoras de $\mathrm{CO}_{2}$. A abreviação adotada para os minerais normati vos corresponde à empregada originalmente pelos idealizadores do método.

Nefelina sienitos

Estas rochas, excluído o fato de serem as mais abundantes, apresentam também maior distribuição geográfica, estan do presentes, pràticamente, em tôdas as partes do corpo. A varieda. de representativa do grupo (Fotomicrografia 7) tem côr cinza claro e textura hipidiomórfica de granulação fina (média: $0,61 \mathrm{~mm}$ ), sendo freqtentes, contudo, variações texturais e tipos de granulação média. $(1,22$ a $1,50 \mathrm{~mm}$ ) e grossa (acima de $3 \mathrm{~mm}$ ). For am também observa das rochas inequigranulares, com cristais maiores de feldspato alca lino e nefelina, atingindo os primeiros até $5 \mathrm{~cm}$ em sua maior dimensão (Am。14 e 24).

Em geral, feldspatos e feldspatóides, em propor ções variadas e tendo como valores extremos 29:71 (Am. 26) e 73:27 (Am. 27), constituem seus principais componentes, ocupando de $70 \%$ a $90 \%$ das rochas (Tabelas Ia e Ib). Ortoclásio pertítico e micropertí tico, com presença subordinada de albita, representam o grupo dos feldspatos, enquanto que nefelina, cancrinita e sodalita o grupo dos feldspatóides. Os piroxênios são os minerais ferromagnesianos mais comuns e, não obstante exibam certa mudança de composição (molécula de Eg variando aproximadamente de 50 a $65 \%$ ), a julgar por seus dados ópticos e químicos, situam-se todos no campo da egirina-augi ta de Tröger (1956). Biotita, perfazendo por vêzes até $6 \%$ da roch a (Am. 33 e 40), forma, juntamente com melanita, pectolita (Am, 10), fluorita, eucolita, minerais A e B, os seus constituintes acidentais. Dentre os acessóxios, titanita, apatita e magnetita merecem desta que, ocorrendo como produtos de alteração o agregado mineralógi. . co resultante da decomposição de nefelina, bem como calcita, mineral C e minerais do grupo das zeólitas.

Do ponto de vista químico, os nefelina sienitos de Itapirapuã, representados por uma composição média de 8 análises 
( Tabela XI), distinguem-se de rochas similares por seu teor relativa mente mais alto em álcalis e bajxo em sílica, resultando essas dife renças provàvelmente de sua maior riqueza em feldspatos e feldspa tóides. Quanto às outras características químicas, mostram-se com paráveis às várias composições médias de rochas congêneres, referi das na literatura e reproduzidas na tabela citada.

Melanita-nefelina sienitos

Estas rochas, a exemplo das anteriores, exibem distribuição irregular dentro do corpo alcalino. Texturalmente, têm como feiçao característica a presença de um "fabric" inequigranular em que os cristais maiores de feldspato alcalino, alcançando dimensões centimétricas (caso particular da Am. 3 , onde atingem até $3 \mathrm{~cm}$ de comprimento), exibem estrutura poiquilítica (Fotomicrografia 8), com melanita, piroxênios e titanita como inclusões. A massa funda mental é de granulação fina, variando de 0,14 mm (Am. ㅇ) a $1,0 \mathrm{~mm}$ $(\operatorname{Am} \underline{4})$.

Do ponto de vista mineralógico, diferem dos nefelina sienitos normais pela presença, em quantidade apreciável (acima de 5\%), de melanita na moda (Fotomicrografia 9), assim como de um maior teor em máficos (Tabelas Ia e Ib). A melanita tem composição variável dentro dêsse grupo de rochas, com o teor em $\mathrm{TiO}_{2}$ passando de 4,56 a 6,59, enquanto que os piroxênios, de natureza e girina-augitạ, contêm em sua composição de 25 a $50 \%$ da molécula de Eg. Biotita é o acidental mais importante, chegando a ocupar até $5,2 \%$ de seu volume (Am. 1 ). Como acessórios e secundários estão presentes os mesmos minerais dos nefelina sienitos normais.

Quimicamente, quando confrontados com rochas se melhantes (Tabela XII), média de 3 análises de Magnet Cove (Erickson e Blade, 1963, p. 61) e de 2 análises da Ilha de Alnd (von Eckermann, 1948, p. 50), os melanita-nefelina sienitos de Itapirapuã contêm, dada a maior constância e riqueza de melanita da moda, teores considerà velmente mais elevados em $\mathrm{Fe}_{2} \mathrm{O}_{3}, \mathrm{CaO}$ e $\mathrm{TiO}_{2}$. 
TABELA XII

Composição química de melanita - nefelina - sienitos

1

2

3

$\mathrm{SiO}_{2}$

45,81

48,54

47,54

$\mathrm{TiO}_{2}$

1,20

0,76

0,84

$\mathrm{Al}_{2} \mathrm{O}_{3}$

17,84

20,01

20,61

3,92

4,36

2,02

2,89

0,31

0,27

$\mathrm{MnO}$

1,39

0,75

0,83

5, 71

6, 75

$\mathrm{CaO}$

9,44

8,08

7,20

$\mathrm{K}_{2} \mathrm{O}$

5,72

6,39

6,49

$\mathrm{H}_{2} \mathrm{O}$

1,29

1,68

0,82

$\mathrm{P}_{2} \mathrm{O}_{5}$

0,61

0,16

0,39

$\mathrm{CO}_{2}$

0,70

1,04

0,47

S

0,08

0,03

0,06

Total

99,61

99,40

99,52

1. Média de 7 análises. Itapirapuã.

2. Média de 3 análises. Magnet Cove, Arkansas, E.U.A.(Erickson e Blade, 1963, p.61).

3. Média de 2 análises. Ilha de Alnơ, Suécia. (von Eckermann, 1948, p.50). 
Biotita me1teigito

Presente na extremidade sul do corpo, borda. W, (Am. 1, da Fig。 4) exibe textura porfirútica e indice de coloração al to, com os minerais máficos ocupando aproximadamente $65 \%$ de seu volume (Fotomicrografia 10). Fenocristais de biotita, atingindo di = mensão máxima de $0,5 \mathrm{~cm}$, são vistos imersos em massa fundamental hỉpidiomórfica de granulação fina $(0,30 \mathrm{~mm})$. Quanto à composi ção mineralógica (Tabela Ia), nefelina e seus produtos de alteração (cancrinita e agregado) representam os constituintes claros, enquanto que piroxênio soda augita é o ferromagnesiano mais importante. Cite-se, ainda, ao lado da expressiva quantidade de biotita na moda (7\%), o elevado teor de titanita na rocha, correspondendo aproxima damente a 5, 4\% de seu volume. Como acessórios, em ordem de abun dância, for am identificados magnetica e apatita.

As peculiaridades químicas do biotita melteigito de Itapirapuã, reflexos de sua maior quantidade de nefelina e também da natureza provàvelmente mais sódica de seu piroxênio, residem nos teores altos em $\mathrm{Al}_{2} \mathrm{O}_{3}$ e $\mathrm{Na}_{2} \mathrm{O}$ e baixos em CaO e $\mathrm{MgO}$ (Tabela XITI), comparativamente a rochas congêneres mundiais.

\section{Melanita malignito}

O melanita malignito forma, a exemplo do bioti. ta melteigito, um único afloramento de rocha estudado, êste localiza do na parte sul, borda E, do corpo (Am. 2 da Fig. 4). Ostenta textu ra inequigranular (Fotomicrografía 11) e alto índice de coloração, o cupando os máficos mais de $50 \%$ da rocha. Fenocristais de piroxế nios e cristais maiores de feldspato alcalino e nefelina, com dimen. sões máximas de $0,4 \mathrm{~cm}$, destacam-se em uma matriz macroscòpicamente escura, hipidiomórfica de granulação fina $(0,13 \mathrm{~mm})$. Es trutura poiquilitica, com nefelina, piroxênio e melanita como inclu sões, tem no feldspato alcalino o cristal hospedeiro mais frequente. Nefelina e agregado resultante de sua composição são seus constituin tes félsicos, guardando feldspatos e feldspatóides uma relação aproximada de 14:86 (Tabela Ia). Pixoxênio, de composição egîrina augi ta e portador de baixa proporção (25\%) da molécula de Eg, constitui., 
TABELA XIII

Composição química de melteigitos

$\begin{array}{llll}1 & 2 & 3 & 4\end{array}$

$\begin{array}{lcccr}\mathrm{SiO}_{2} & 40,9 & 40,64 & 38,3 & 41,90 \\ \mathrm{TiO}_{2} & 2,75 & 2,24 & 4,19 & 2,21 \\ \mathrm{Al}_{2} \mathrm{O}_{3} & 16,1 & 10,58 & 14,8 & 12,20 \\ \mathrm{Fe}_{2} \mathrm{O}_{3} & 5,06 & 4,18 & 5,37 & 6,41 \\ \mathrm{FeO} & 4,55 & 4,18 & 6,95 & 4,32 \\ \mathrm{MnO} & 0,23 & 0,28 & 0,23 & 0,22 \\ \mathrm{MgO} & 3,82 & 6,47 & 6,85 & 5,45 \\ \mathrm{CaO} & 13,5 & 19,91 & 12,06 & 16,60 \\ \mathrm{Na}_{2} \mathrm{O} & 7,13 & 4,75 & 2,80 & 5,10 \\ \mathrm{~K}_{2} \mathrm{O} & 2,26 & 1,86 & 3,81 & 2,66 \\ \mathrm{H}_{2} \mathrm{O} & 1,06 & 0,41 & 3,71 & 0,87 \\ \mathrm{P}_{2} \mathrm{O}_{5} & 1,61 & 1,91 & 0,62 & 1,24 \\ \mathrm{CO}_{2} & 0,47 & 2,08 & - & 0,82\end{array}$

S

0,05

Total

$99,44 \quad 99,54$

99,69

100,00

1. Biotita melteigito. Itapirapuã.

2. Biotita melteigito. Melteig, Fen district, Norway (Brogger, 1921). Citação em Johannsen (1938, IV, p. 330).

3. Biotita melteigito. Tha da Trindade (Almeida, 1961, p.146)。

4. Média de 9 análises.(Nockolds, 1954, p.1028). 
juntamente com a melanita, contendo $6,97 \%$ de $\mathrm{TiO}_{2}$, os minerais fer. romagnesianos dominantes. E particularmente interessante, a exemplo do verificado com o biotita melteigito descrito, o elevado teor de titanita idiomórfica na rocha, totalizando cêrca de 4,6\% de seu volume. O mineral acessório reconhecido foi apatita e como produto de alter ação, ao lado do agregado citado acima, está presente o mine ral C, êste de hábito fibroso e natureza desconhecida, representando, provàvelmente, um outro mineral de alteração da nefelina.

Dada a definição extremamente ampla do têrmo pe trográfico malignito, caracterizando para muitos Autores sienitos melanocráticos portadores ou não de feldspatóides, tornou se proble mática qualquer análise comparativa entre a amostra brasileira e congêneres mundiaîs. Não obstante tal dificuldade, procedeu-se à eLaboração da Tabela XIV na qual a composição química da rocha de I tapir apuã está relacionada a uma composição média de 25 análises de malignitos (Nockolds, 1954, p. 1024), bem como a duas outras de melanita malignitos provenientes das localidades de Kruger na Co lúmbia Britânica e de Assynt na Escócia e citadas em Johannsen (1938, IV, p. 117)。 O exame dessa tabela possibilita a verificação de que, a exceção de $\mathrm{MgO}$, todos os demais óxidos mostram teores mui to variáveis entre si: contudo, parecem ser significativas as porcen tagens mais elevadas em $\mathrm{Fe}_{2} \mathrm{O}_{3}, \mathrm{CaO}$ e $\mathrm{TiO}_{2}$ e baixa em $\mathrm{SiO}_{2}$ da amostra brasileira, consequência da maior quantidade de melanita em. sua moda.

Variedades enriquecidas

Wollastonita-melanita-nefelina sienito

Esta rocha, representando um único afloramento situado na região setentrional do corpo (Am, 20, da Fig. 4), forma, juntamente com o cancrinita mariupolito e pulaskito, as variedades petrográficas enriquecidas da província. No presente caso, êste enri quecimento foi em cálcio, que é evidenciado pela abundância de wol. lastonita e melanita na composição modal e pelo aparecimento, em quantidades apreciáveis, de wollastonita e ortossilicato de cálcio(cs) como componentes normativos, perfazendo os 2 pares de minerais, 
TABELA XIV

Composição química de malignitos

1

2

3

4

$\begin{array}{lcccr}\mathrm{SiO}_{2} & 43,4 & 50,49 & 45,06 & 47,42 \\ \mathrm{TiO}_{2} & 2,15 & 0,92 & 1,25 & 1,66 \\ \mathrm{Al}_{2} \mathrm{O}_{3} & 17,7 & 15,83 & 20,95 & 16,03 \\ \mathrm{Fe}_{2} \mathrm{O}_{3} & 6,70 & 6,11 & 6,23 & 5,68 \\ \mathrm{FeO} & 1,99 & 3,04 & 2,84 & 5,16 \\ \mathrm{MnO} & 0,27 & 0,11 & - & 0,25 \\ \mathrm{MgO} & 3,24 & 3,38 & 3,31 & 3,35 \\ \mathrm{CaO} & 12,4 & 7,99 & 8,32 & 6,99 \\ \mathrm{Na}_{2} \mathrm{O} & 6,96 & 3,12 & 3,51 & 7,67 \\ \mathrm{~K}_{2} \mathrm{O} & 3,47 & 6,86 & 4,09 & 3,50 \\ \mathrm{H}_{2} \mathrm{O} & 1,41 & 1,49 & 4,28 & 1,36 \\ \mathrm{P}_{2} \mathrm{O}_{5} & 0,93 & 0,42 & 0,66 & 0,71 \\ \mathrm{CO}_{2} & 0,27 & 0,07 & - & 0,22\end{array}$

S

0,15

Total

$101,04 \quad 99,83 \quad 100,50 \quad 100,00$

1. Melanita malignito. Itapirapuã.

2. Melanita malignito. Kruger, British Columbia. (Daly, 1912).Citação em Johannsen(1938, IV, p. 117).

3. Melanita malignito. (Ledmorito). Ledmore River, Assynt, Scotland (Shand, 1910). Citação em Johannsen (1938, IV, p.117).

4. Média de 25 análises. (Nockolds, 1954, p.1024). 
em ambos os casos, mais de $20 \%$ da rocha (Tabela XV). Sua textura. é hỉpidiomórfica, de granulação fina $(0,90 \mathrm{~mm})$, e a côr é predomi. nantemente rósea, não obstante a rocha se apresente em geral salpi cada de manchas brancas e pontos negros, causados pela presença macroscópica de cristais prismáticos de wollastonita e de grânulos equidimensionais de melanita. Do ponto de vista mineralógíco, ao la do da presença de melanita e wollastonita (Fotomicrografia 12), ca racteriza-se ainda por possuir uma relação feldspatos:feldspatóides muito baixa, da ordem de 14:86, e por conter em sua composição um piroxênio, de natureza egirina-augita, trazendo aproximadamen te $30 \%$ da molécula de Eg. Apatita e magnetita constituem os seus minerais acessórios, enquanto que calcita forma com o agregado os produtos de alter ação.

Quîmicamente, tem como feição marcante o ca ráter fortemente insaturado, refletido na presença de nefelina, leu. cita, perorskita e ortossilicato de cálcio na análise normativa, e a extrema riqueza em cálcio como frisado acima. Uma busca cuida dosa, com o propósito de encontrar rochas sieníticas mineralógíca e quîmicamente comparáveis à amostra de Itapirapuã, revelou-se infrutifera. Quanto à espectrografia, verifica-se que os valores obtidos para os elementos detectados situam-se indistintamente, den tro do campo de variação para as diferentes rochas da região. tral vez seja merecedor de ligeiro reparo, o comportamento do elemento $\mathrm{Y}$, a julgar pelo teor superior ao da quase totalidade das amos tras investigadas.

Cancrinita mariupolito

Esta rocha estå representada dentro do maciço al calino por afloramento localizado na sua extremidade E (Am. 22 da Fig. 4). Sua textura é hip idjomórfica de granulação fina $(0,26 \mathrm{~mm})$ e a cổ branca, por vêzes, algo amarelade como resultado da pre sença de cristais de cancrinita (Fotomicrografia 13). Do ponto de vista mineralógico, tem como característica marcante a ausência de nefelina e feldspato alcalino em sua composição, formando-se can crinita e um plagioclásio, de natureza albítica, em seu lugar (Tabela XVI.). A cancrinita é sempre informe e ocorre ocupando os in - 
TABELA XV

\begin{tabular}{|c|c|c|c|c|c|c|c|c|}
\hline \multicolumn{4}{|c|}{ Composição química } & \multirow{2}{*}{\multicolumn{3}{|c|}{$\begin{array}{c}\text { Norma } \\
\text { molecular }\end{array}$}} & \multirow{2}{*}{\multicolumn{2}{|c|}{$\begin{array}{l}\text { Análise } \\
\text { modal }\end{array}$}} \\
\hline$\%$ Pêso & & ppm & & & & & & \\
\hline $\mathrm{SiO}_{2}$ & 41,3 & $\mathrm{Be}$ & 7,2 & $\mathrm{Lc}_{\mathrm{c}}$ & & 19,18 & $\begin{array}{l}\text { Feldspato } \\
\text { Alcalino }\end{array}$ & 9,7 \\
\hline $\mathrm{TiO}_{2}$ & 1,85 & $\mathrm{Ga}$ & 25 & $\mathrm{Ne}$ & & 29,82 & & \\
\hline $\mathrm{Al}_{2} \mathrm{O}_{3}$ & 15,2 & $\mathrm{Cr}$ & 5 & & & & Nefelina & 54,2 \\
\hline $\mathrm{Fe}_{2} \mathrm{O}_{3}$ & 7,53 & $\mathrm{~V}$ & 220 & $\mathrm{Ac}$ & & 4,62 & Agregado & 2,7 \\
\hline $\mathrm{FeO}$ & 1,43 & Mo & 7 & $\mathrm{Di}$ & Wo & 6,73 & Piroxênio & 8,2 \\
\hline $\mathrm{MnO}$ & 0,24 & $\mathrm{Nb}$ & 110 & & En & 5,80 & Melanita & 13,8 \\
\hline $\mathrm{MgO}$ & 2,32 & $\mathrm{Sn}$ & nd & Wo & & 8,64 & Magnetita & $\operatorname{tr}$ \\
\hline $\mathrm{CaO}$ & 17,2 & $\mathrm{Ni}$ & 10 & $\mathrm{Cs}$ & & 12,30 & Apatita & 1,4 \\
\hline $\mathrm{Na}_{2} \mathrm{O}$ & 7,14 & Co & 7,5 & $\mathrm{Hm}$ & & 5,92 & Calcita & 1,6 \\
\hline $\mathrm{K}_{2} \mathrm{O}$ & 4,18 & $\mathrm{Cu}$ & 110 & Il & & 3,26 & Biotita & $\operatorname{tr}$ \\
\hline $\mathrm{H}_{2} \mathrm{O}^{+}$ & 0,32 & $\mathrm{Sc}$ & 6,8 & $\mathrm{Pf}$ & & 0,20 & Wolla stonita & 8,4 \\
\hline $\mathrm{H}_{2} \mathrm{O}^{-}$ & 0,12 & $\mathrm{Zr}$ & 340 & Ap & & 2,69 & $\begin{array}{l}\text { Feldspatos: } \\
\text { Feldspatóides }\end{array}$ & $14: 86$ \\
\hline $\mathrm{P}_{2} \mathrm{O}_{5}$ & 1,19 & $\mathrm{Y}$ & 124 & $\operatorname{Pr}$ & & 0,18 & Siálicos: & \\
\hline $\mathrm{CO}_{2}$ & 0,29 & La & 170 & $\mathrm{Cc}$ & & 0,60 & Máficos & $67: 33$ \\
\hline S & 0,11 & $\begin{array}{l}\mathrm{Sr} \\
\mathrm{Pb}\end{array}$ & $\begin{array}{r}560 \\
\text { nd }\end{array}$ & $\mathrm{H}_{2} \mathrm{O}$ & & 0,44 & $\begin{array}{l}\text { Coeficiente } \\
\text { Agpaŕtico: }\end{array}$ & 0,74 \\
\hline
\end{tabular}

Total: $100,34 \mathrm{Ba} 320$ Total: 100,38 Pêso específico: 2,92 †

Analistas: Elementos principais - Silvia Lourdes Moro (I.P.T.). Elementos traços - Cláudio Vieira Dutra (I. T.I.). 
TABELA XVI

Cancrinita mariupolito

Composição química

$\%$ Pêso

$\begin{array}{llll}2 & 55,4 & \mathrm{Be} & 10\end{array}$

$\mathrm{TiO}_{2}$

$0,35 \mathrm{Ga}$

45

$\mathrm{Cr}$

1,4 An

Norma

molecular

Or

$\mathrm{Ab}$

$\mathrm{Al}_{2} \mathrm{O}_{3}$

20,0

$6,08 \quad \mathrm{~V}$

$18 \mathrm{Ne}$

4,3

$\mathrm{FeO}$

$\mathrm{MnO}$

$\mathrm{MgO}$

$\mathrm{CaO}$

$\mathrm{Na}_{2} \mathrm{O}$

$0,40 \quad$ Mo

154

$0,17 \mathrm{Nb}$

$0,10 \mathrm{Sn}$

6,

$1,52 \quad \mathrm{Ni}$

1,5

10,3

Co

$1,5 \mathrm{Mt}$

2, $72 \mathrm{Cu} \quad 68 \mathrm{Hm}$

$\mathrm{K}_{2} \mathrm{O}$

$1,50 \quad \mathrm{Sc}$ nd II

$\mathrm{H}_{2} \mathrm{O}^{+}$

$\mathrm{H}_{2} \mathrm{O}$

0,14

$\mathrm{P}_{2} \mathrm{O}_{5}$

0,2

1,06

La 170

0,11

Sr 680

$\mathrm{Pb} 41$

$\mathrm{CO}_{2}$

$\mathrm{Pb} \quad 41$

Análise

modal.

Total: 100,09 Ba 360

53,0

53,81 Nefelina

$0,28 \quad$ Agregado

17.98 Cancrinita

Piroxênio

0,23 Melanita

0,20 Titanita

Calcita

0,58 Fluorita

5,68 Mineral A

0,61 Feldspatos:

Feldspatóides

0,18

Siálicos:

2,40

Máficos

Coeficiente

1,64

agpaitico:

Pêso específico:

2,67
12,3

0,5

tr.

0,3

tr。

0,2

$61: 39$

$87: 13$

0,65

.

r。

tr。

33,7

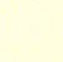


terstícios dos cristais de piroxênio e plagioclásio. Este possui hábito ripiforme e mostra-se comumente geminado segundo a lei da Albita.O piroxênio tem composição situada no campo da egirina de Tr\&ger(1956) e é portador, a julgar pelos dados químicos obtidos, de $83 \%$ da molécu la de Eg. Dos acessórios comuns às demais rochas da provincia, sòmen te titanita foi reconhecida, enquanto que do grupo dos minerais aciden taìs e de alteração estão presentes: melanita, mineral A, fluorita e call. cita.

O cancrinita mariupolito de Itapirapuã, quando confrontado com as demais variedades Litológícas da província, tem como feições químicas distintivas os teores elevados em $\mathrm{Na}_{2} \mathrm{O}$ (reflexo da presença de $53 \%$ de albuta na sua moda e da natureza sódíca do pi̊roxênio) e Ga e o conteúdo muito baixo em V. Uma análisse comparativa, reu. nindo a composição da rocha investigada com aquelas referentes ao beckelita mariupolito da regĩão de Marĭupolo Rússia (citação em Johan nsen, 1938, IV, p.213) e uma composǐção média de 9 análises dada por Nockolds (1954, p.1024), é apresentada na Tabela XVII. O seu exame permite verificar a existência de grande semelhança nos dados quími . cos fornecidos e as pequenas diferenças encontradas, teor maior em $\mathrm{CO}_{2}$ e menor em $\mathrm{Na}_{2} \mathrm{O}$ da amostra de Itapirapuä, podem ser interpre tadas"como resultante da maior presença de cancrinita, em lugar de nefelina, nesta rocha.

Pula skito

Pulaskito é a rocha mais potássica da província, decorrendo tal fato da sua extraordinária riqueza em feldspato alcalino, cêrca de $83,3 \%$, como se về na análise modal fornecida na Tabela XVIII. Ao lado dêsse fato, representa também dentre os têrmos petrográficos analisados e contendo feldspatos em sua composição, a var L̃edade porta dora da mais alta relação feldspatos: feldspatóides, aproximadamente 94 : 6. Quanto à textura, comporta-se como a maioria das rochas da re giẫo, em que tem sido observado comumente um "fabric" hipidiomórfi. co de granulação fina. 0,30 mm (Fotomicrografia 14). A sua côr é bran co-acinzentado. A exemplo do wollastonita-melanita-nefelina sienito e cancrinita mariupolito, aflor num único ponto do interior do corpo al. calino, êste localizado na sua extremidade norte (Am. 21 da Fig.4). 
TABELA XVII

Composição químỉca de mariupolitos

123

$\begin{array}{lccr}\mathrm{SiO}_{2} & 55,4 & 54,66 & 56,47 \\ \mathrm{TiO}_{2} & 0,35 & 0,29 & 0,43 \\ \mathrm{Al}_{2} \mathrm{O}_{3} & 20,0 & 22,61 & 21,26 \\ \mathrm{Fe}_{2} \mathrm{O}_{3} & 6,08 & 4,10 & 3,37 \\ \mathrm{FeO} & 0,40 & 1,64 & 1,44 \\ \mathrm{MnO} & 0,17 & 0,16 & 0,16 \\ \mathrm{MgO} & 0,10 & 0,18 & 0,33 \\ \mathrm{CaO} & 1,52 & 1,08 & 1,50 \\ \mathrm{Na}_{2} \mathrm{O} & 10,3 & 12,32 & 11,63 \\ \mathrm{~K}_{2} \mathrm{O} & 2,72 & 2,13 & 2,21 \\ \mathrm{H}_{2} \mathrm{O} & 1,64 & 0,62 & 0,77 \\ \mathrm{P}_{2} \mathrm{O}_{5} & 0,24 & - & 0,08 \\ \mathrm{CO} & 1,06 & - & 0,24 \\ \mathrm{~S} & 0,11 & - & 99,89 \\ \mathrm{Total}_{2} & 100,09 & 99,79 & \cdots\end{array}$

1. Cancrinita mariupolito. Itapirapuã.

2. Beckelita mariupolito. Mar de Azov, Mariupol. Rússia.(Morozewicz, 1902). Contém 0,2 de beckelita. Citação em Johannsen (1938, IV, p.212).

3. Média de 9 análises. (Nockolds, 1954 . p. $1024 \pi$. 
TABELA XVIII

$$
\text { Pulaskito }
$$

$\%$ Pêso

Composição química

$$
\text { Norma }
$$

molecular

$\mathrm{SiO}_{2} \quad 56,2 \quad \mathrm{Be}$

7,2 Or

$$
68,39
$$

$\mathrm{Ab}$

2,62

$\mathrm{TiO}_{2}$

$0,52 \mathrm{Ga}$

37

$\mathrm{Ne}$

$$
9,09
$$

Nefelina

Análise

$\mathrm{Al}_{2} \mathrm{O}_{3} \quad 16,3 \quad \mathrm{Cr} \quad \mathrm{n}$

140

$\mathrm{Fe}_{2} \mathrm{O}_{3}$

$$
4,89 \mathrm{~V}
$$

$\mathrm{MnO}$

1. 72 Mo

Ac

$0,15 \mathrm{Nb} \quad 560$

$\mathrm{MgO}$

$0,89 \mathrm{Sn}$

nd

$\mathrm{CaO}$

3,03 Ni

4,7

Ac

5,08

5,08
2,55

Agregado

modal.

$\mathrm{Na}_{2} \mathrm{O}$

2,96 Co

nd

Di

Wo 2, 55

Cancrinita

$\mathrm{K}_{2} \mathrm{O}$

$11,6 \mathrm{Cu}$

34

Wo

En 2, 20

Piroxênio

$\mathrm{H}_{2} \mathrm{O}^{+}$

$1,23 \mathrm{Sc}$

5

Mt $\mathrm{Fs}$

Melanita

3,1

$\mathrm{H}_{2} \mathrm{O}=$

$0,25 \mathrm{Zr} \quad 400$

II

1,86

Titanita

3,7

$\mathrm{P}_{2} \mathrm{O}_{5}$

$0,10 \quad \mathrm{Y} \quad 230$

$\mathrm{Cc}$

4,64

Magnetita

0,5

$\mathrm{CO}_{2}$

0,72 La nd

$\mathrm{H}_{2} \mathrm{O}$

0,91

Calcita

2,5

$\mathrm{S}$

* Sr 480 $\mathrm{Pb}$ nd

Total: 100,56 Ba 3500

Total 100,42

Clorita

Feld spatos:

Feldspatóides

$94: 6$

Siálicos:

Máficos

$87: 13$

Coeficiente

Agpaítico:

0,89

Pêso e specífico: 2,67

Analistas: Elementos principais - Glória Berenice C.T.C.Brazão da Silva (L。P.M。).

Elementos traços - Cláudio Vieira Dutra (I. T.I.). 
Mineralògicamente, à exceção da abundâncila em feldspato alcalinno, pou co tem de distintivo, sendo os seus minerais acidentais, acessórios e de alteração, comuns à quase totalidade das rochas investigadas do dis trito.

Do ponto de vista químico, o pulaskito difere das demais rochas de Itapirapuã em razão do seu conteúdo muito alto em $\mathrm{K}_{2} \mathrm{O}$, como evidenciado não só na própria análise química, mas tam bém na composição normativa. Quanto à composição espectrográfica. excetuando $\mathrm{Nb}$ e Y cujos teores determinados estão acima dos obtidos para as rochas da região, todos os elementos detectados acusaram valores situados dentro do campo de variação dessas rochas.

\section{Tinguaŕtos}

Estas rochas, como demonstra o mapa geológico da Fig. 3, estão presentes no interior e fora do maciço alcalino. No se gundo caso, as evidếncias de campo indicam que sua intrusão se pro cessou na forma de pequenos diques verticais, de poucos decímetros de espessura. Contudo, na parte interna do corpo, não for am local iza dos afloramentos "in situ" de tinguaítos e os pontos assinalados no ma pa geológico referem-se apenas aos locais, em geral situados nos leïtos de córregos, onde os blocos dessas rochas foram encontrados. Es ses blocos são prontamente reconhecidos no campo em razão de sua côr cinza-esverdeado, maior resistência à ação intempérica e seu fơ mato arredondado ou mesmo discóide. Quando removidasas crostas de alteração que os capeíam, verifica-se que essas rochas têm côr ver de. For am reconhecidas, em tôdas as seç̧ões delgadas estudadas, tex tura tinguaítica (Fotomicrografia 15) evidenciada pela presença de cris tais aciculares de piroxênios dispostos caóticamente no interior da rocha, e porfirítica. Esta última caracteriza-se pela presença de feno cristais, com dimensões variáveis entre 1,50 e $2,25 \mathrm{~mm}$, de nefelina e feldspato alcalino $e$, subordinadamente de piroxênios, imersos em massa fundamental de granulação finíssima $(0,02$ e $0,05 \mathrm{~mm})$. A pro porção de minerais ferromagnesianos nessas rochas, como indicado pe los constituintes normativos máficos das amostras 18 e 19 (ver Tabela XXIV) parece sícuar-se ao redor de 10\%. Feldspato alcalino, em ge $r$ al muito limpido e geminado segundo a lei de Carlsbad, e nefelina são 
os minerais claros e piroxênios, o ferromagnesiano dominante. O feldspato, a julgar pelos dados ópticos obtidos para a amostra 19c (Ta bela III), corresponde a um ortoclásio portador de aproximadamente $40 \%$ da molécula de albita ( $\left.\mathrm{Ab}_{93} \mathrm{An}_{07}\right)$. Magnetita e, mais raramente , titanita formam: no grupo dos acessórios e cancrinita, sodalita, calcí ta e, por vêzes, zeólitas constituem os produtos de alteração da nefe. lina. Pirita, visível macroscòpicamente e exibindo forma cúbica bem desenvolvida, tem sido encontrada disseminada em algumas dessas ro chas, o mesmo sucedendo com sodalita.

Quimicamente, os tinguaítos da província de Itapi rapuã, representados por uma composição média de 2 análises, não exibem diferenças marcantes a ponto de distingui-los prontamente de composições médias de rochas similares extraídas da literatura e reproduzidas na Tabela XIX.

Carbonatitos

Carbonatitos, na forma de veios irregulares, cor m tam os nefelina sienitos (Fotos 3 e 4) e foram encontrados num único lo cal dentro do corpo alcalino. Ocupam aproximadamente sua parte central. Estes veios, em geral com poucos centímetros de largura mos tram-se, por vêzes, portadores de pequenos fragmentos de dimensões centimétricas das rochas encaixantes. A sua área de exposição é mui. to reduzida, parecendo limitar-se a uns poucos afloramentos observa dos numa encosta de morro de acentuado declive e difícil acesso face à intensa cobertura vegetal existente.

Possuem textura sacaróide, granulação média (1,5 a 3,0 mm) e composição mineralógica simples (Tabela XX)。 ca racterizada, principalmente, pela presença de calcita (único constituin te carbonático identificado) e ortoclásio corroído, êste em proporções variadas, como seus minerais essenciais, ao lado de apatita, magnetita e pirrotita como acessórios (Fotomicrografia 16). Nefelina melani-m ta. e zircão estão presentes na condição de minerais acidentais. Foram. observadas nessas rochas concentrações de apatita e a análise modal. de uma delas $(\mathrm{C}-4 \mathrm{c})$ acusou aproximadamente $20 \%$ dêsse mineral.

0 exame da Tabela $\mathrm{XX}$, contendo as análises modaiss executadas, possibilita verificar que, excetuando a amostra $\mathrm{C}-2$, tôda 
TABELA XIX

Composição química de tinguaítos

$\begin{array}{lccccc} & 1 & 2 & 3 & 4 & 5 \\ \mathrm{SiO}_{2} & 52,75 & 52,85 & 53,10 & 55,02 & 52,11 \\ \mathrm{TiO}_{2} & 0,46 & 0,33 & * & 0,36 & 0,39 \\ \mathrm{Al}_{2} \mathrm{O}_{3} & 22,05 & 19,44 & 19,07 & 20,42 & 18,30 \\ \mathrm{Fe}_{2} \mathrm{O}_{3} & 2,34 & 4,82 & 5,57 & 3,06 & 3,53 \\ \mathrm{FeO} & 1,51 & 0,57 & - & 1,82 & 1,72 \\ \mathrm{MnO} & 0,15 & 0,13 & 0,17 & 0,59 & 0,35 \\ \mathrm{MgO}^{2} \mathrm{O} & 0,37 & * & 0,22 & 0,25 \\ \mathrm{CaO} & 1,46 & 2,53 & 1,33 & 1,67 & 3,68 \\ \mathrm{Na}_{2} \mathrm{O} & 10,03 & 8,87 & 9,41 & 8,63 & 10,22 \\ \mathrm{~K}_{2} \mathrm{O} & 6,31 & 7,96 & 6,84 & 5,38 & 4,06 \\ \mathrm{H}_{2} \mathrm{O} & 0,78 & 0,85 & 3,98 & 2,77 & 4,71 \\ \mathrm{P}_{2} \mathrm{O}_{5} & 0,30 & 0,04 & * & 0,06 & 0,13 \\ \mathrm{CO}_{2} & 1,66 & 0,13 & 0,10 & - & 0,32\end{array}$

S

0,04

Total

$$
99,80 \quad 100,36 \quad 99,57 \quad 100,00 \quad 99,77
$$

1. Média de 2 análises. Itapirapuã.

2. Tinguaito. Magnet Cove, Arkansas, E.U.A. (Erickson e Blade, 1963, p.41).

3. Tinguaito. Rio de Janeiro, Brasil.(Rosenbusch, 1898). Citação em Johannsen (1938, IV; p. 148).

4. Média de 15 análises. (Daly, 1933, p.27).

5. Média de 2 análises. Toror Hills, Uganda (Hytbnen, 1959, pp. 83 e 92). 


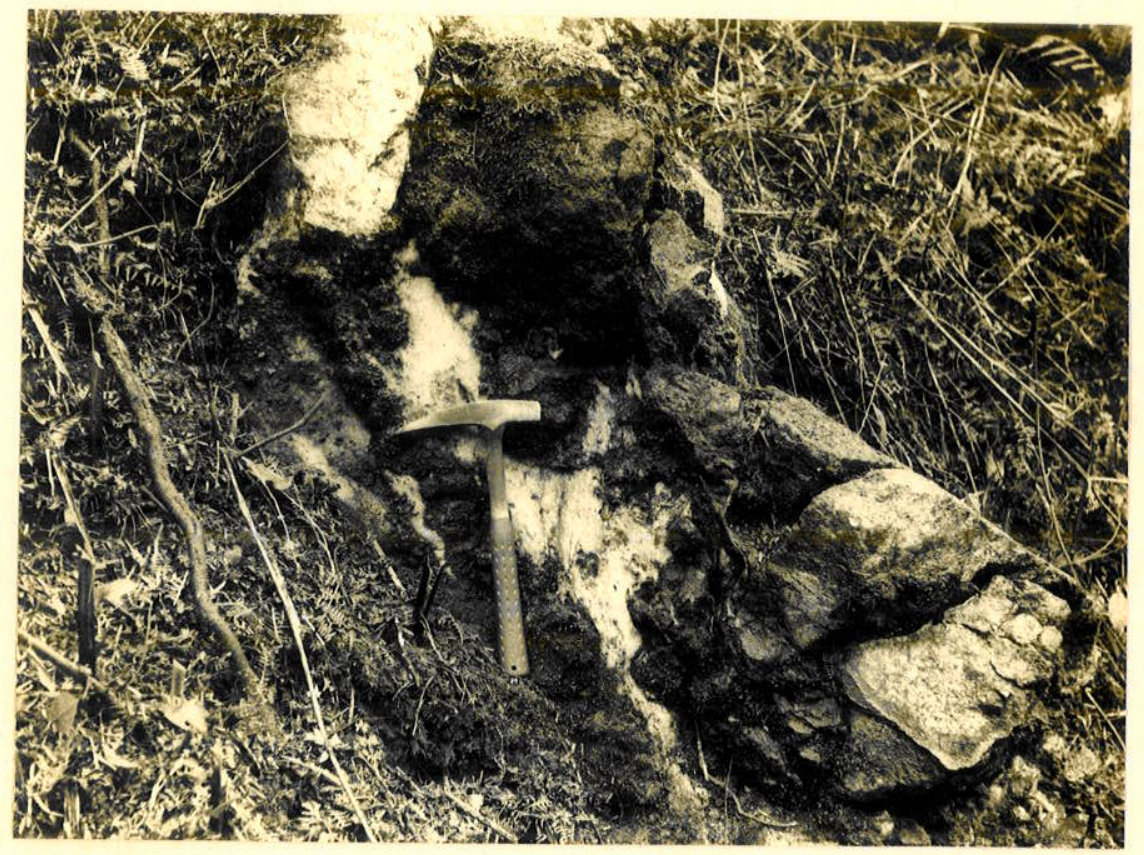

Foto 3 - Veios irregulares, de poucos centímetros de lar gura(côr branca), de carbonatito cortando nefe $\overline{1 i}$ na sienitos(côr cinza), de granulação média.

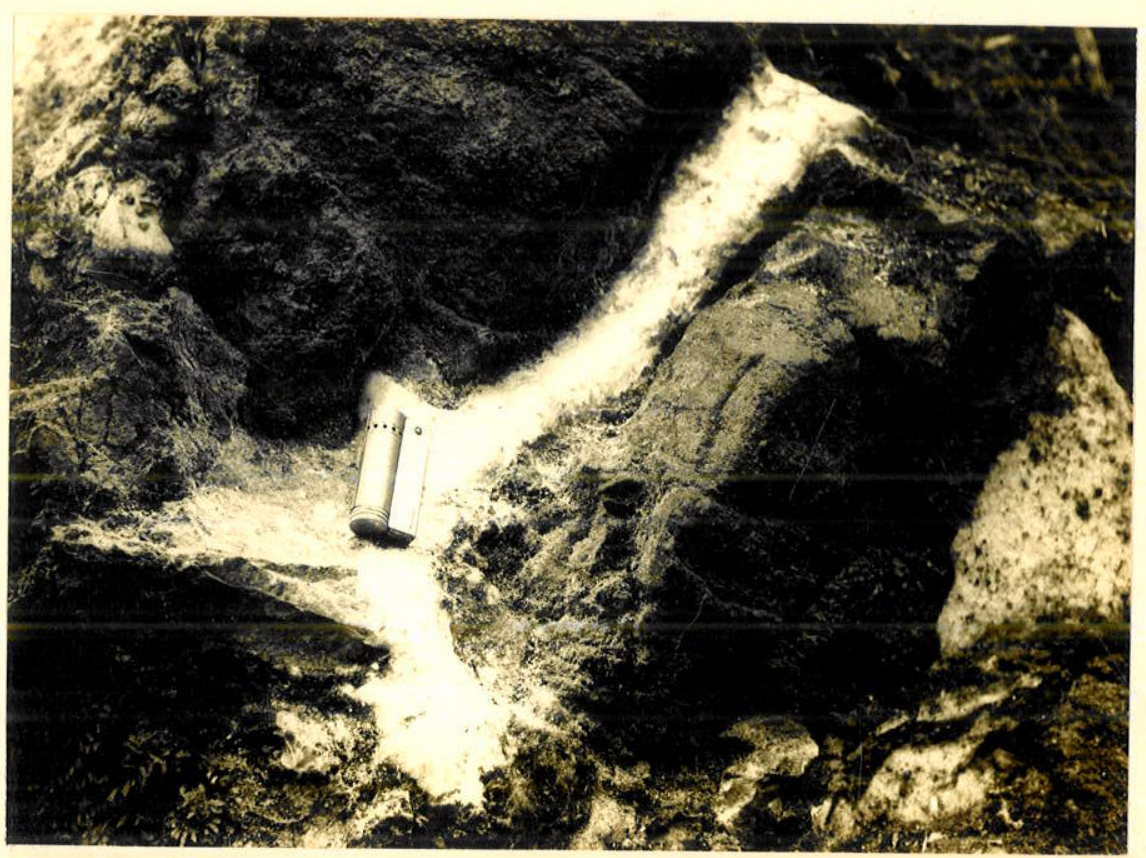

Foto 4 - Veios irregulares, de poucos centímetros de lar gura(côr branca), de carbonatito cortando nefelina sienitos(côr cinza), de granulação média. 


\section{TABELA XX}

Análises modais: Carbonatitos

\section{Calcita Feldspato Apatita Opacos Outros*}

$\begin{array}{lcrrrrc} & \text { A } & 50,9 & 45,4 & - & 2,8 & 0,9 \\ \mathrm{C}=1 & \mathrm{~B} & 28,7 & 69,6 & 1,2 & 0,1 & 0,7 \\ \mathrm{C}-2 & \mathrm{C} & 71,4 & 28,5 & - & - & 0,1 \\ & & 99,3 & - & - & 0,7 & - \\ \mathrm{C}-3 & \mathrm{~A} & 62,6 & 35,3 & 0,3 & 0,1 & 1,7 \\ & \mathrm{~B} & 54,8 & 35,7 & 7,7 & 0,9 & 1,0 \\ & \mathrm{C} & 38,0 & 60,5 & 0,3 & 0,4 & 0,7 \\ \mathrm{C}-4 & \mathrm{~A} & 84,6 & 14,3 & 0,7 & 0,4 & - \\ & \mathrm{B} & 81,5 & 15,9 & 1,3 & 0,4 & 0,9 \\ \text { Média } & \mathrm{C} & 45,5 & 34,9 & 19,4 & 0,2 & - \\ \text { Variação } & 28,7-99,3 & 0-69,6 & 0-19,4 & 0-2,8 & 0-1,7\end{array}$

${ }^{*}$ Estão incluídos: nefelina, melanitave zircão (?).

Amostras analisadas quimicamente: C-1A, C-2, C-3A e C-4C. 
a.s demais apresentam em sua composição mais de $10 \%$ de ortoclásio, Levando nos a classificá-las petrogràficamente, segundo as sugestões propostas por von Eckermann (1948, p. 13), como ortoclásuo sovito. A amostra $\mathrm{C}-4 \mathrm{C}$, com ortoclásio e apatita em quantidade superior a $10 \%$, seria classificada, adotando-se idêntico critér - ortoclásio sovito.

Análises químicas para elementos traços de 4 a mostras de carbonatitos estão representadas na Tabela XXI, junta mente com o valox médio determinado para cada elemento. Examinan do-se esta tabela verifica-se que os resultados obtidos, para cada ele mento, guardam razoável concordância entre si, excluindo-se even . tualmente os teores mais elevados em $\mathrm{Nb}$ e $\mathrm{Ba}$ da amostra $\mathrm{C}-1$. Os va lores médios acima citados, quando comparados com os correspon dentes aos de 22 amostras de rochas alcalinas do distrito, mostram -se comumente inferiores, exceção feita aos elementos $\mathrm{Cr}, \mathrm{Cu}, \mathrm{Sr}$ e Ba. (ver Tabelas XXVa e XXVb).

Um quadro comparativo reunindo a média de 4 aná Lises de carbonatitos de Itapirapuã juntamente com a composição do carbonatito de Magnet Cove (Exickson e Blade, 1963, p.35), a com posição média de 53 análises do maciço de Kaiserstuhl (van Wambeke, 1964, p. 97) e as composições "média" e "trpica" de Gold (1966, no prelo) constitul a Tabela XXII. A simples observação desta tabela. mostra que uma análise completa das várias composições fornecidas é extremamente difícil, senão mesmo umpraticável, dado o fato de alguns elementos traços não terem sido determinados em tôdas as análises e também em virtude do limite de sensibilidade tomado pa$x$ a cada elemento sex em geral diferente nas análises consideradas. Contudo, uma apreciaçăo de largos traços parece indicar que os ele mentos $\mathrm{Cr}$, V, Co, Ni, Zr, Sr, Ba e Mo estão menos concentrados nos carbonatitos de Itapirapuã que nos demais, enquanto que o inver so parece ter ocorrido com $\mathrm{Cu}$.

\section{Brecha magmátíca}

Uma zona brechada aflora na parte sul do corpo e parece cobrir área de algumas dezenas de metros quadrados. Macros copicamente, distinguem se fragmentos, em geral arredondados, de 
TABELA XXI

Análisesquímicas (elementos traços) dos carbonatitos de Itapirapuã

$\begin{array}{lrrrrrr}\text { ppm } & \text { C }-1 & \text { C }-2 & \text { C }-3 & \text { C }-4 & \text { Variação } & \text { Média } \\ \mathrm{Be} & \text { nd } & \text { nd } & \text { nd } & \text { nd } & \text { nd } & \text { nd } \\ \mathrm{Ga} & 15 & 11 & 13 & 11 & 11-15 & 12,5 \\ \mathrm{Cr} & 12 & 16 & 14 & 20 & 12-20 & 15,5 \\ \mathrm{~V} & 32 & 36 & 48 & 34 & 32-48 & 37 \\ \mathrm{Mo} & \mathrm{nd} & \mathrm{nd} & \mathrm{nd} & \mathrm{nd} & \mathrm{nd} & \mathrm{nd} \\ \mathrm{Nb} & 320 & 106 & 93 & 93 & 93-320 & 153 \\ \mathrm{Sn} & 4,7 & 7,8 & 6,3 & 6,3 & 4,7-7,8 & 6,3 \\ \mathrm{Ni} & 1,6 & 1,5 & 1,5 & 1,5 & 1,5-1,6 & 1,5 \\ \mathrm{Co} & 4,3 & 4,7 & n d & n d & 0-4,7 & 2,2 \\ \mathrm{Cu} & 140 & 80 & 140 & 90 & 80-140 & 112 \\ \mathrm{Sc} & \mathrm{nd} & 10 & \mathrm{nd} & \mathrm{nd} & 0-10 & 2,5 \\ \mathrm{Zr} & 23 & 24 & 20 & 20 & 20-24 & 22 \\ \mathrm{Y} & 36 & 58 & 58 & 46 & 36-58 & 49 \\ \mathrm{La} & 300 & 400 & 420 & 420 & 300-420 & 385 \\ \mathrm{Sr} & 1600 & 1340 & 1400 & 1300 & 1300-1600 & 1410 \\ \mathrm{~Pb} & 24 & 28 & 28 & 17 & 17-28 & 24 \\ \mathrm{Ba} & 3200 & 1520 & 1800 & 1460 & 1460-3200 & 1995 \\ & & & & & \end{array}$

Analista: Cláudio Vieira Dutra (I.T.I。). 
TABELA XXII

Análises químicas (elementos traços) de carbonatitos

$\begin{array}{lcrrcc}\text { ppm } & 1 & 2 & 3 & 4 & 4 a \\ \mathrm{Be} & \text { nd } & 1 & * & 4,4 & 5 \\ \mathrm{Ga} & 12,5 & \ldots & * & 2,6 & 2,4 \\ \mathrm{Cr} & 15,5 & - & 18 & 66 & 102 \\ \mathrm{~V} & 37 & 200 & 150 & 94 & 105 \\ \mathrm{Mo} & \mathrm{nd} & 10 & 20 & 59 & 64 \\ \mathrm{Nb} & 153 & - & 620 & * & * \\ \mathrm{Sn} & 6,3 & * & 20 & 1,1 & 2,5 \\ \mathrm{Ni} & 1,5 & - & 5 & 17,5 & 32,4 \\ \mathrm{Co} & 2,2 & - & 14 & 21,5 & 18,8 \\ \mathrm{Cu} & 112 & 10 & 17 & 30,3 & 88 \\ \mathrm{Sc} & 2,5 & - & * & 11 & 10 \\ \mathrm{Zr} & 22 & 10 & 43 & 925 & 461 \\ \mathrm{Y} & 49 & 40 & 45 & 337,8 & 113,7 \\ \mathrm{La} & 385 & 300 & 800 & * & * \\ \mathrm{Sr} & 1410 & 5000 & 6500 & 6800 & 7500 \\ \mathrm{~Pb} & 24 & \ldots & 55 & 54 & 27 \\ \mathrm{Ba} & 1995 & \cdots & 5000 & 3600 & 4000\end{array}$

1. Média de 4 análises. Itapirapuã.

2. Carbonatito. Magnet Cove, Arkansas, E.U.A. (Erickson e Blade, 1963, p.35).

3. Média de 53 análises. Kaiserstuh]. Alemanha Ocidental (ran Wambeke, 1964, p.97).

4. Composição química "média". (Gold, 1966, no prelo).

5. Composição química "típica". (Gold, 1966, no 
dimensões centimétricas, ocupando, numa estimativa muito grossei ra, cêrca de 30 a $40 \%$ do volume da rocha (Fotos 5 e 6). Os frag mentos têm comumente a mesma côr da matriz, cinza em tonalidades claras e escuras e cinza-esverdeado, e a sua pronta distinção no cam po decorre muito mais do intemperismo diferencial atuante nas rochas, do que qualquer outro fator. Por vêzes, na zona de contato fragmentos/ /matriz, as rochas exibem coloração muito diversa do restante, em geral levemente avermelhada, sendo tal fato resultante da infiltração neste local de soluções corantes de natureza ferruginosa e de origem secundária. A vista desarmada, fragmentos e matriz parecem ter a mesma composição mineralógica, esta correspondendo à dos sienitos nefelínicos da região. Isto, contudo, nem sempre se verifica e há a mostras em que os fragmentos são pràticamente uniminerálicos e constituídos, ora de feldspato alcalino, ora de ferromagnesianos bio títa e piroxênio. Não for am encontrados blocos da rocha granítica que serve de encaixante ao corpo alcalino. Da mesma forma, não foram reconhecidos fragmentos de brecha, o que nos leva a acreditar na existência de uma única fase cataclástica. Conclusão análoga foi al cançada por Penalva (1962, p.119) em seu trabalho sôbre a brecha magmática do Itatiaia.

Do ponto de vista microscópico, fragmentos e matri.z, excetuando aquêles de composição uniminerálica, não mostram diferenças marcantes quanto à mineralogia. Feldspato alcalino, nefelina - e seus produtos de alteração - piroxênios e granada são seus componentes essenciais, ocorrendo subordinadamente biotita, titani ta. magnetita e apatita. Feições texturais indicativas de ação de es forços dinâmicos for am encontrados, indistintamente em fragmentos e matriz, em tôdas as lâminas investigadas. Dentre essas, merecent destaque a presença constante de fraturas e fissuras nos grânulos das rochas, ao lado de seu preenchimento por minerais secundários, em especial os de natureza carbonática: extinção ondulante em feldspatos e outros minerais; encurvamento de linhas de clivagem e estrias de ge minação, etc. Não for am encontrados quaisquer vestígios indicativos da presença de estrutura fluidal nessas rochas. 


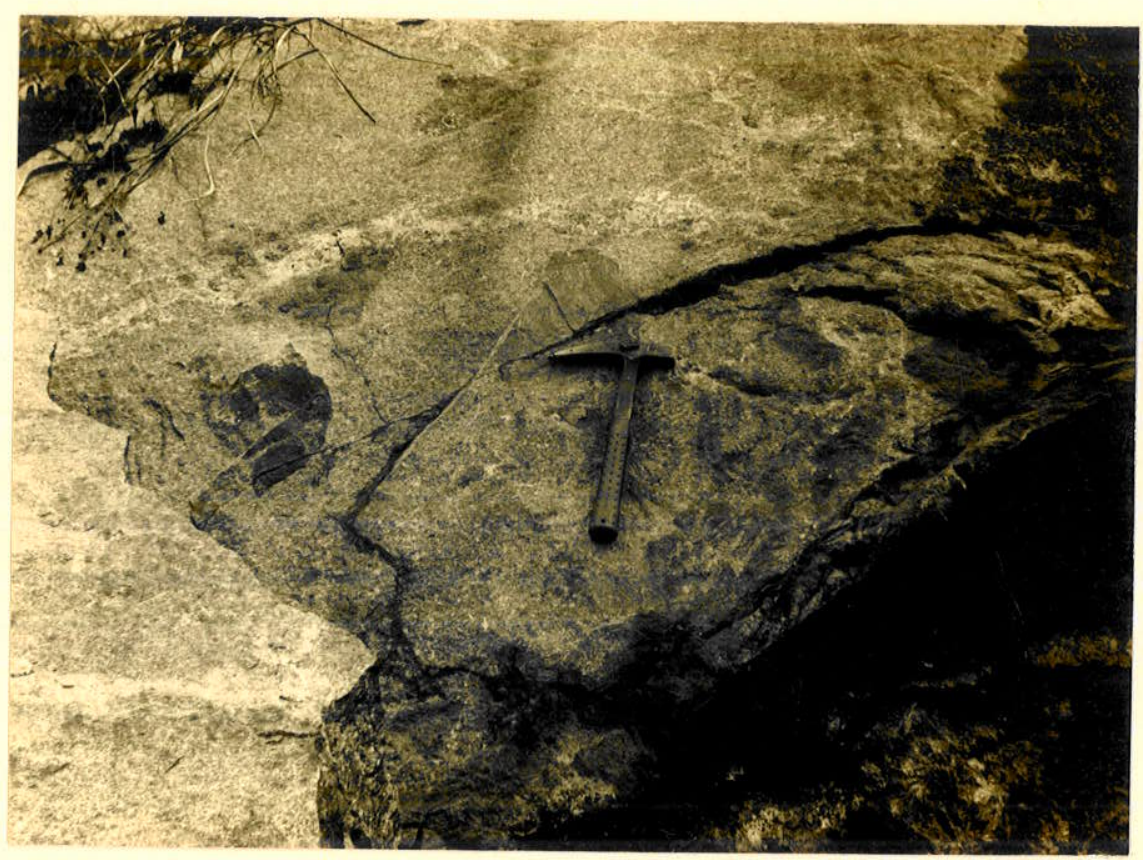

Foto 5 - Afloramento de brecha magmática

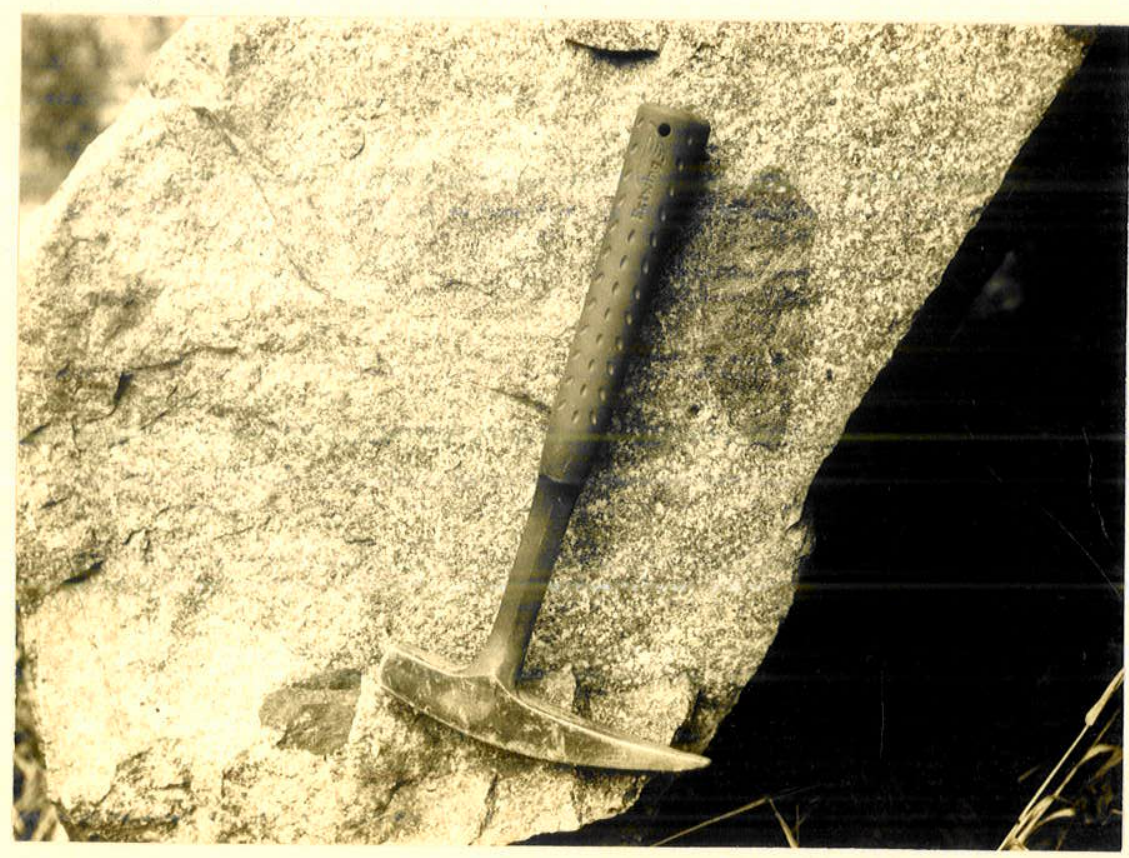

Foto 6 - Afloramento de brecha magmática 


\title{
GEOQUIMICA
}

\author{
Introdução
}

As análises químicas das rochas da província, com exceção das relativas ao wollastonita-melanita-nefelina sienito, can crinita mari̊upolito e pulaskito anômalos, estão agrupadas nas Tabe las XXIII a XXVb, com base nas associações mineralógícas presen tes e em ordem crescente do Indice félsico de Simpson (1954), enquan to que suas normas moleculares, calculadas segundo o método CIPW, integram a Tabela XXIV。Essas análises, recalculadas para $100 \% \mathrm{com}$ subtração de água total, a.cham-se representadas nas Tabelas XXVa e XXVb na forma catiônica, com os valores expressos em partes por milhão, ao lado de dados espectrográficos obtidos para 17 elementos traços e também de relações diversas reunindo os seus componentes principais e menores. Constam igualmente dessa tabela, os valores encontrados para o pêso específico das rochas investigadas.

Como características químicas gerais dessas ro chas destacam-se: a pobreza em sîlica, abundância em cálcio, álca lis e voláteiss, aliadas a concentrações elevadas em V, Nb, Cu. Y Y Ba. A riqueza em álcalis é prontamente realçada pelo valor do seu ín dice "agpaítico" (Ussing, 1911). Esta relação, reunindo o conteúdo to tal de sódio e potássio pelo teor de aluminio ( $\mathrm{Na}$ K/Al das Tabelas $X X V a, X X V b$, etc。), varia de 0,58 a 0,89 , tendo como valor médio. 0,72 . Os Indices "agpaíticos" obtidos (inferiores ao valor minimo de 1,2 estabelecido para as rochas "agpaiticas") formam ao lado das feições mineralógicas, as evidências indicativas, segundo Gerasimovski̊ (1956) e Sbrensen (1960), do caráter tîpicamente "miasquítico" das ro chas que compõem o maciço.

O grau de alcalinidade da província de Itapirapuã foi estabelecido, de conformidade com Peacock (1931, p. 54), a par . tir do diagrama de variação da. Fig. 17. Nêle verifica-se que o Indice álcali-cálcico é de aproximadamente 43,5, o que possibilita uncluir es sa ocorrência dentro da série alcalina daquele Autor (cf. Peacock a séri̊e é denominada alcalina quando o indice é inferòor a 51) ou, então, na série hiperalcalina de Almeida (1961, p. 166). Eiste Autor acres centou às quatro classes de séries eruptivas de Peacock (1931), uma 


\section{TABELA. XXIII}

Biotita Melanita

Análises químicas

\begin{tabular}{|c|c|c|c|c|c|c|c|c|c|c|c|c|c|c|c|c|c|c|c|}
\hline$\%$ Pêso & 1 & 2 & 3 & 4 & 5 & 6 & 7 & 8 & 9 & 10 & 11 & 12 & 13 & 14 & 15 & 16 & 17 & 18 & 19 \\
\hline $\mathrm{SiO}_{2}$ & 40,9 & 43,4 & 44,4 & 47,5 & 45,7 & 44,2 & 46,3 & 48,1 & 49,0 & 49,8 & 50,1 & 48,0 & 53,6 & 53,9 & 53,6 & 52,8 & 53,0 & 53,0 & 52,5 \\
\hline $\mathrm{TiO}_{2}$ & 2,75 & 2,15 & 1,28 & 1,00 & 1,07 & 1,50 & 1,00 & 1,00 & 0,93 & 0,55 & 0,44 & 0,37 & 0,50 & 0,12 & 0,24 & 0,60 & 0,35 & 0,58 & 0,35 \\
\hline $\mathrm{Al}_{2} \mathrm{O}_{3}$ & 16,1 & 17,70 & 16,5 & 17,5 & 18,8 & 18,0 & 17,3 & 19,2 & 20,2 & 21,0 & 21,6 & 22,7 & 19,7 & 24,0 & 21,1 & 21,4 & 24,3 & 21,6 & 22,5 \\
\hline $\mathrm{Fe}_{2} \mathrm{O}_{3}$ & 5,06 & 6,70 & 7,68 & 7,37 & 4,08 & 7,34 & 7,98 & 4,23 & 5,80 & 6.22 & 3,45 & 1,55 & 5,19 & 2,67 & 4,35 & 4,02 & 2,69 & 1,35 & 3,33 \\
\hline $\mathrm{FeO}$ & 4,55 & 1,99 & 1,95 & 0,60 & 1,81 & 1,60 & 1,75 & 1,61 & 0,40 & 0,71 & 0,79 & 1,03 & 0,80 & 1,30 & 0,44 & 1,24 & 0,51 & 2,16 & 0,87 \\
\hline $\mathrm{MnO}$ & 0,23 & 0,27 & 0,29 & 0,21 & 0,24 & 0,28 & 0,22 & 0,13 & 0,14 & 0,21 & - & 0,07 & 0,20 & - & 0,10 & 0,19 & 0,18 & - & - \\
\hline $\mathrm{MgO}$ & 3,82 & 3,24 & 1,69 & 0,24 & 1,76 & 1,65 & 1,50 & 1,28 & 0,89 & - & 0,47 & 0,42 & 0,63 & 0,21 & - & 0,10 & 0,10 & 0,12 & 0,18 \\
\hline $\mathrm{CaO}$ & 13,5 & 12,40 & 11,40 & 9,31 & 9,22 & 8,64 & 7,20 & 6,55 & 6,05 & 4,00 & 3,87 & 3,59 & 2,51 & 2,20 & 2,55 & 1,90 & 1,69 & 1,69 & 1,24 \\
\hline $\mathrm{Na}_{2} \mathrm{O}$ & 7,13 & 6,96 & 6,72 & $-6,20$ & 8,96 & 8,76 & 7,54 & 7,32 & 6,50 & 8,63 & 9,37 & 11,30 & 9,05 & 7,80 & 6,21 & 8,18 & 9,50 & 10,40 & 9,67 \\
\hline $\mathrm{K}_{2} \mathrm{O}$ & 2,26 & 3,47 & 4,40 & 6,76 & 4,68 & 4, i 3 & 6,25 & 7,45 & 7,91 & 6,81 & 7,23 & 7,00 & $\dot{6}, 46$ & 5,97 & 9,68 & 7,16 & 7,44 & 6,88 & 5,75 \\
\hline $\mathrm{H}_{2} \mathrm{O}^{+}$ & 0,95 & 1,00 & 2,24 & 1,63 & 1,70 & 0,45 & 0,37 & 1,00 & 0,60 & 2,04 & 0,32 & 2,54 & 0,55 & 0,56 & 0,71 & 0,24 & 0,32 & 0,84 & 0.32 \\
\hline $\mathrm{H}_{2} \mathrm{O}^{-}$ & 0,11 & 0,41 & 0,92 & 0,33 & 0,41 & 0,03 & 0,09 & 0.01 & 0,10 & 0,30 & 0,12 & 0,26 & 0,03 & 0,18 & 0,10 & 0,05 & 0,05 & 0,29 & 0,11 \\
\hline $\mathrm{P}_{2} \mathrm{O}_{5}$ & 1,61 & 0,93 & 0,96 & 0,07 & 067 & 0,61 & 0,67 & 8,35 & 0,35 & 0,08 & 0,19 & 0,14 & 0,17 & 0,21 & 0,43 & 0,12 & 0,05 & 0,29 & 0,32 \\
\hline $\mathrm{CO}_{2}$ & 0,47 & 0,27 & 0,39 & 1,08 & 0,90 & 0,90 & 0,98 & 0,75 & 0,30 & 0,11 & 1,12 & 1,16 & 0,69 & 0,56 & 0,50 & 0,06 & 0,33 & 1,43 & 1,90 \\
\hline s & - & 0,15 & - & - & - & 0,33 & 0,03 & 0,06 & 0,10 & 0,13 & $\curvearrowright, *$ & $0,4.3$ & $0 * 11$ & $*$ & 0,03 & 0.02 & 0,02 & * & * \\
\hline Total & 99,44 & 101,04 & 100,82 & 99,80 & 100,00 & 98,42 & 90.18 & 99,05 & 99,27 & 100,59 & 99,07 & 100,56 & 100,19 & 99,68 & 100,04 & 98,08 & 100,53 & 100,63 & 99,04 \\
\hline
\end{tabular}

(*) näo dosado;

(-) não encontrado

Analistas: Glória Berenice C.T.C. Brazão da Silva (L. P.M.) - Amostras: 1, 3 a 5 e 12.

Silvia Lourdes Moro (I. P. T.) - Amostras: 2, 6 a 10, 13, 15 a 17 ,

Benedito Alves Ferreira (I. G. G.) - Amostras: $11,14,18$ e 19. 
TABELA XXIV

Norma molecular

Biotita Melanita
melteigito malignito

\begin{tabular}{|c|c|c|c|c|c|c|c|c|c|c|}
\hline \multirow{2}{*}{\multicolumn{2}{|c|}{ Or }} & 1 & 2 & 3 & 4 & 5 & 6 & 7 & 8 & 9 \\
\hline & & 12,51 & 13,62 & 26,13 & 40,03 & 21,13 & 24,46 & 27,80 & 29,47 & 42,26 \\
\hline \multicolumn{2}{|l|}{$\mathrm{Ab}$} & - & - & 2,62 & 2,10 & - & $\mathrm{r}, 31$ & - & - & - \\
\hline \multicolumn{2}{|l|}{ An } & 5,28 & 6,67 & 1,95 & - & - & - & - & - & 2,50 \\
\hline \multicolumn{2}{|l|}{ Lcc } & 0,65 & 5,45 & - & - & 5,23 & - & 6,98 & 11,34 & 3,49 \\
\hline \multicolumn{2}{|l|}{$\mathrm{Ne}$} & $32,-66$ & 31,81 & 29,25 & 26,69 & 38,06 & 36,78 & 29,54 & 30,96 & 29,82 \\
\hline \multicolumn{2}{|l|}{$\mathrm{Ne}$} & - & - & - & - & - & - & - & - & - \\
\hline \multicolumn{2}{|l|}{ c } & - & - & - & - & - & - & - & - & - \\
\hline \multirow{2}{*}{\multicolumn{2}{|c|}{$\begin{array}{l}\text { Ac } \\
\text { Ns }\end{array}$}} & - & - & - & - & 5,08 & 4,16 & 8,32 & 4,16 & - \\
\hline & & - & - & - & 3,70 & - & - & - & - & - \\
\hline Ns & Wo & 11,02 & 9,40 & 4,87 & 0,50 & 5,10 & 4,76 & $\leqslant, 29$ & 3,31 & 2,55 \\
\hline \multirow[t]{2}{*}{$D i$} & En & 9,50 & 8,10 & 4,20 & - & 4,40 & 4,10 & 3,70 & 3,20 & 2,20 \\
\hline & Fs & - & - & - & - & - & - & - & - & - \\
\hline \multirow{2}{*}{01} & Fo & - & - & - & - & - & - & - & - & - \\
\hline & $\mathrm{Fa}$ & - & - & - & - & - & - & - & - & - \\
\hline \multicolumn{2}{|l|}{ Wo } & 9,63 & 10,67 & 14,50 & 15,43 & 9,36 & 9,40 & 6,26 & $7,-19$ & 6,67 \\
\hline \multicolumn{2}{|l|}{$\mathrm{Cs}$} & - & - & - & - & - & - & - & - & - \\
\hline \multicolumn{2}{|l|}{ Mt } & 7,42 & 0,34 & 3,25 & - & 3,25 & 0,46 & 3,25 & 2,55 & - \\
\hline \multicolumn{2}{|l|}{$\mathrm{Hm}$} & - & 6,48 & 5,44 & 7.36 & 0,16 & 5,60 & 2,88 & 0.96 & 5,76 \\
\hline \multicolumn{2}{|l|}{ II } & 5,17 & 4,10 & 2,43 & 1,67 & 2,13 & 2,89 & 1,98 & 1,82 & 0,84 \\
\hline \multicolumn{2}{|l|}{$P f$} & - & - & - & 0,27 & - & - & - & - & 0,88 \\
\hline \multicolumn{2}{|l|}{ Ap } & 3,70 & 2,02 & 2,35 & - & 1,68 & 1,34 & 1,68 & 0,67 & 0,67 \\
\hline \multicolumn{2}{|l|}{ Pr } & - & 0,30 & - & - & - & 0,60 & - & 0,12 & 0,18 \\
\hline \multicolumn{2}{|l|}{$\mathrm{Cc}$} & 1,10 & 0,60 & 0,90 & 2,50 & 2,00 & 2,00 & 2,30 & 1,70 & 0,70 \\
\hline \multicolumn{2}{|c|}{$\mathrm{H}_{2} \mathrm{O}$} & 1,00 & 1,41 & 3,16 & 1,96 & 2,11 & 0,48 & 0,46 & 1,02 & 0,70 \\
\hline \multicolumn{2}{|c|}{ Total } & 99,70 & 100,97 & 101,05 & 99,31 & 100,19 & 98,34 & 99,46 & 98,87 & 99,22 \\
\hline
\end{tabular}

Nefelina sienitos

Tinguaítos

$\begin{array}{cccccccccc}10 & 11 & 12 & 13 & 14 & 15 & 16 & 17 & 18 & 19 \\ 40,03 & 38,09 & 25,58 & 38,36 & 35,56 & 57,27 & 42,81 & 43,92 & 40,59 & 33,92 \\ 5,24 & - & - & 12,84 & 27,25 & 6,03 & 15,20 & 9,43 & 14,15 & 32,49 \\ - & - & - & - & 7,23 & 1,11 & 0,28 & 1,67 & - & - \\ - & 3,71 & 12,21 & - & - & - & - & - & - & - \\ 35,22 & 38,34 & 42,32 & 28,26 & 21,02 & 25,14 & 29,25 & 38,34 & 31,81 & 19,03 \\ - & - & - & - & - & - & - & - & 0,85 & 2,86 \\ - & - & - & - & 1,94 & - & - & - & - & 3,16 \\ 2,31 & 7,39 & 4,16 & 10,16 & - & - & - & - & 3,70 & - \\ - & - & 2,93 & - & - & - & - & - & 1,59 & - \\ - & 1,39 & 1,97 & 1,86 & - & - & 0,23 & 0,23 & - & - \\ - & 1,20 & 1,00 & 1,60 & - & - & 0,20 & 0,20 & - & - \\ - & - & 0,92 & - & - & - & - & - & - & - \\ - & - & - & - & 0,35 & - & - & - & 0,21 & 0,40 \\ - & - & - & - & - & - & - & - & 2,25 & - \\ 8,00 & 3,71 & 2,32 & 1,51 & - & 2,44 & 3,60 & 1,67 & - & - \\ - & - & - & - & - & - & - & - & - & - \\ 0,93 & 1,16 & - & 1,60 & 3,71 & 0,93 & 2,78 & 1,16 & - & 1,86 \\ 4,30 & 0,16 & - & 0,48 & 0,16 & 3,68 & 2,08 & 1,92 & - & 2,08 \\ 1,06 & 0,91 & -0,76 & 0,91 & 0,30 & 0,46 & 1,22 & 0,61 & 1,06 & 0,61 \\ - & - & - & - & - & - & - & - & - & - \\ - & - & - & - & - & 1,01 & - & - & 0,67 & 0,67 \\ 0,24 & - & 0,36 & 0,12 & - & - & - & - & - & - \\ 0,20 & 2,50 & 2,70 & 1,60 & 1,30 & 1,10 & - & 0,70 & 2,40 & 1,60 \\ 2,34 & 0,44 & 2,80 & 0,58 & 0,74 & 0,81 & 0,29 & 0,37 & 1,13 & 0,43 \\ 100,37 & 98,56 & 100,03 & 99,88 & 99,56 & 99,98 & 97,94 & 100,22 & 100,41 & 99,11 \\ & & & & & & - & & & \end{array}$




\begin{tabular}{|c|c|c|c|c|c|c|c|c|c|c|c|}
\hline \multirow{2}{*}{\multicolumn{2}{|c|}{$\mathrm{s}$}} & \multirow[t]{2}{*}{$\mathrm{ppm}$} & $\begin{array}{c}\text { Biotita } \\
\text { melteigito }\end{array}$ & $\begin{array}{l}\text { Melanita } \\
\text { malignito }\end{array}$ & \multicolumn{7}{|c|}{ Melanita-nefelina aienitos } \\
\hline & & & 1 & z & 3 & 4 & 5 & 6 & 7 & 8 & 9 \\
\hline & & $\mathrm{Si}^{4+}$ & $194.10^{3}$ & $203.10^{3}$ & $212,10^{3}$ & $226.10^{3}$ & $218,10^{3}$ & $211.10^{3}$ & $2.19 \cdot 10^{3}$ & $229.10^{3}$ & $232 \cdot 10^{3}$ \\
\hline & & $\mathrm{Al}^{3+}$ & $87.10^{3}$ & $94,10^{3}$ & $89.10^{3}$ & $95.10^{3}$ & $102.10^{3}$ & $97.10^{3}$ & $93.10^{3}$ & $104 \cdot 10^{3}$ & $108 \cdot 10^{3}$ \\
\hline & & $\mathrm{Ti}^{4 t}$ & $17.10^{3}$ & $13.10^{3}$ & B. $10^{3}$ & $6.10^{3}$ & $6.10^{3}$ & $9.10^{3}$ & $6.10^{3}$ & $6.10^{3}$ & $6.10^{3}$ \\
\hline & & $\mathrm{Fe}^{3+}$ & $36.10^{3}$ & $47.10^{3}$ & $55.10^{3}$ & $53.10^{3}$ & $29.10^{3}$ & $52.10^{3}$ & $57.10^{3}$ & $30.10^{3}$ & $41 \cdot 10^{3}$ \\
\hline & & $\mathrm{Mg}^{2+}$ & $23.10^{3}$ & $19,10^{3}$ & $10.10^{3}$ & $1.10^{3}$ & $11.10^{3}$ & $10.10^{3}$ & $9.10^{3}$ & $8.10^{3}$ & $5 \cdot 10^{3}$ \\
\hline & & $\mathrm{Fe}^{2+}$ & $36.10^{3}$ & $15.10^{3}$ & $15.10^{3}$ & $5.10^{3}$ & $14: 10^{3}$ & $13.10^{3}$ & $14.10^{3}$ & $13.10^{3}$ & $3.10^{3}$ \\
\hline & & $\mathrm{Na}^{+}$ & $54,10^{3}$ & $52.10^{3}$ & $51 \cdot 10^{3}$ & $47.10^{3}$ & $68.10^{3}$ & $66.10^{3}$ & $57.10^{3}$ & $55.10^{3}$ & $49.10^{3}$ \\
\hline & & $\mathrm{Ca}^{2+}$ & $98.10^{3}$ & $89.10^{3}$ & $83.10^{3}$ & $68.10^{3}$ & $67.10^{3}$ & $63.10^{3}$ & $52 \cdot 10^{3}$ & $48 \cdot 10^{3}$ & $44 \cdot 10^{3}$ \\
\hline & & $\mathrm{K}^{+}$ & $19 \cdot 10^{3}$ & $29.10^{3}$ & $37.10^{3}$ & $57.10^{3}$ & $40.10^{3}$ & $35 \cdot 10^{3}$ & $52.10^{3}$ & $63 \cdot 10^{3}$ & $66 \cdot 10^{3}$ \\
\hline & 3 & $\mathrm{Be}^{2+}$ & nd & 11 & 10 & 11 & 7.2 & 9.3 & 5,8 & 6,5 & 8 \\
\hline & 3 & $\mathrm{Ga}^{3+}$ & 18 & 22 & 22 & 27 & 21 & 11 & 37 & 30 & 34 \\
\hline & 1 & $C r^{3+}$ & 96 & 5 & 15 & 10 & 12 & 6 & 13 & 9 & 7,4 \\
\hline & 3 & $v^{34}$ & 168 & 230 & 270 & 400 & 180 & 172 & 156 & 200 & 200 \\
\hline & 1 & $\mathrm{Mo}^{4+}$ & 11 & nd & 17 & 12 & 12 & 12 & 6 & 6.8 & 7,8 \\
\hline & 10 & $\mathrm{Nb}^{5+}$ & 170 & 200 & 104 & 180 & 1.33 & 630 & 155 & 225 & 190 \\
\hline & 3 & $\mathrm{Sn}^{4+}$ & 19 & 25 & 19 & 24 & 9.5 & 7.8 & 28 & 14 & 14 \\
\hline & 1 & $\mathrm{Ni}^{2+}$ & 60 & 11 & 11 & 18 & 8 & 8 & 8,6 & 3 & 3,1 \\
\hline & 1 & $\mathrm{Co}^{2+}$ & 13 & 13 & 7,8 & 3 & 7,4 & 6,3 & 6 & 5.2 & 4.7 \\
\hline & 0,3 & $\mathrm{Cu}^{2+}$ & 150 & 160 & 60 & 48 & 140 & $15 \sigma$ & 150 & 80 & 80 \\
\hline & 1 & $\mathrm{Se}^{3+}$ & 26 & 8,6 & net & nd & ndt & 5.2 & nd & 4 & 3,2 \\
\hline & 10 & $2 . r^{4+}$ & 340 & 500 & 740 & 830 & 370 & 345 & 280 & 370 & 410 \\
\hline & 10 & $\mathrm{y}^{3+}$ & 62 & 115 & 124 & 280 & 54 & 90 & 48 & 49 & 58 \\
\hline & 30 & $\mathrm{La}^{3+}$ & 420 & 120 & 220 & nd & IRn & 220 & 160 & 136 & 68 \\
\hline & 10 & $\mathrm{Sr}^{2+}$ & 920 & 700 & 760 & 570 & 840 & 740 & 640 & 590 & 490 \\
\hline & 5 & $\mathrm{~Pb}^{2+}$ & 38 & 38 & 19 & 17 & 43 & 110 & 36 & 34 & 51 \\
\hline & 5 & $\mathrm{Ba}^{2+}$ & 380 & 2000 & 1200 & 3200 & 2800 & 5400 & 3000 & 4800 & 3200 \\
\hline Ga $x$ & $\times 1000 / \mathrm{Al}$ & & 0,21 & 0,23 & 0.25 & 0,28 & 0.21 & 0,11 & 0,40 & 0,29 & 0,31 \\
\hline $\mathrm{Cr} \times$ & $\times 1000 / \mathrm{Mg}$ & & 4,1 & 0,26 & 1.4 & 7,1 & 1,1 & 0,59 & 1,4 & 1.1 & 1,5 \\
\hline$v \times$ & $\times 1000 / \mathrm{Mg}$ & & 7,2 & 12,1 & 25,9 & 285,7 & 16,7 & 17,2 & 17,3 & 25,0 & 40,0 \\
\hline $\mathrm{Ni} \times$ & $\times 1000 / \mathrm{Mg}$ & & 2.6 & 0,58 & 1,1 & 12,8 & 0.74 & 0,80 & 0,95 & 0.37 & 0.52 \\
\hline Co $x$ & $\times 1000 / \mathrm{Mg}$ & & 0,56 & 0.68 & 0,75 & 2.1 & 0.6 .8 & 0,63 & 0.66 & 0,65 & 0,94 \\
\hline Se $\times$ & $\times 1000 / \mathrm{Mg}$ & & 1,1 & 0,44 & - & - & - & 0,51 & - & 0,51 & 0.59 \\
\hline $\mathrm{Fe} / \mathrm{N}$ & & & 3,1 & 3,3 & 6,8 & 41,0 & 1.0 0 & 6.5 & 7,9 & 5,4 & 8,8 \\
\hline$C r$ & $\times 1000 / \mathrm{Fe}$ & & 1,3 & 0,08 & 0.21 & 0,17 & 0,27 & 0,09 & 0,18 & 6.21 & 0.17 \\
\hline $\mathrm{v} \times$ & $\times 1000 / \mathrm{Fe}$ & & 2,3 & 3,7 & 3,8 & 7,0 & 4,1 & 2,6 & 2,2 & 4,6 & 4,5 \\
\hline Co $x$ & $\times 1000 / \mathrm{Fe}$ & & 0,18 & 0,21 & 0,11 & 0,05 & 0.17 & 0,09 & 0,08 & 0,12 & 0,11 \\
\hline Sc $x$ & $1000 / \mathrm{Fe}$ & & 0,36 & 0,14 & - & - & - & 0,08 & - & 0,09 & 0.07 \\
\hline $\mathrm{Y} \times \mathrm{x}$ & $\times 1000 / \mathrm{Ca}$ & & 0,63 & 1,3 & 1,5 & 4,1 & 0,80 & 1,4 & 0,92 & 1,0 & 1,3 \\
\hline Sr $x$ & $100 / \mathrm{Ca}$ & & 0,94 & 0,79 & 0,91 & 0,84 & 1,2 & 1,2 & 1,2 & 1,2 & 1,1 \\
\hline Sr $\times$ & $=100 / \mathrm{Ca}+$ & $\mathrm{K}$ & 0,78 & 0,48 & 0,63 & 0,45 & 0,78 & 0,75 & 0,61 & 0,53 & 0,44 \\
\hline $\mathrm{Bax}$ & $100 / \mathrm{K}$ & & 2,0 & 3,5 & 3,2 & 5,6 & 7,0 & 12.0 & 5,8 & 7,6 & 4.8 \\
\hline $\mathrm{Fe}^{2+}$ & $++\mathrm{Fe}^{3+}$ & & 42,8 & 38,4 & 41,7 & 35,2 & 26.9 & 36,9 & 37,1 & 25,4 & 26.8 \\
\hline Alk & & & 43,3 & 49,6 & 52,2 & 63.9 & 66,4 & 57,4 & 58,1 & 70,0 & 69.9 \\
\hline $\mathrm{Mg}$ & & & 13,9 & 12,0 & 6,1 & 0,9 & 6.7 & 5.7 & 4,8 & 4.6 & 3.3 \\
\hline $\mathrm{Na}+$ & $\mathrm{K} / \mathrm{Al}$ & & 0,58 & 0.59 & 0,67 & 0,74 & 0,72 & 0,72 & 0,80 & 0.77 & 0,71 \\
\hline Pêso & especiffico & & 2,91 & 2,91 & 2,83 & 2,76 & 2,71 & 2,80 & 2,78 & 2,78 & 2,77 \\
\hline (Nat & K) $\times 100 / \mathrm{N}$ & $\mathrm{Na}+\mathrm{K}+\mathrm{Ca}$ & 42,6 & 47,4 & 51,5 & 60,6 & 61,5 & 61,6 & 67,7 & 71,3 & 72,5 \\
\hline
\end{tabular}

(S) limite de sensibilidade;

(nd) não detectado;

(-) nǎo encontrado; 
TAlil:AA $\times \times$ Vb

Anillafe quimitan

s

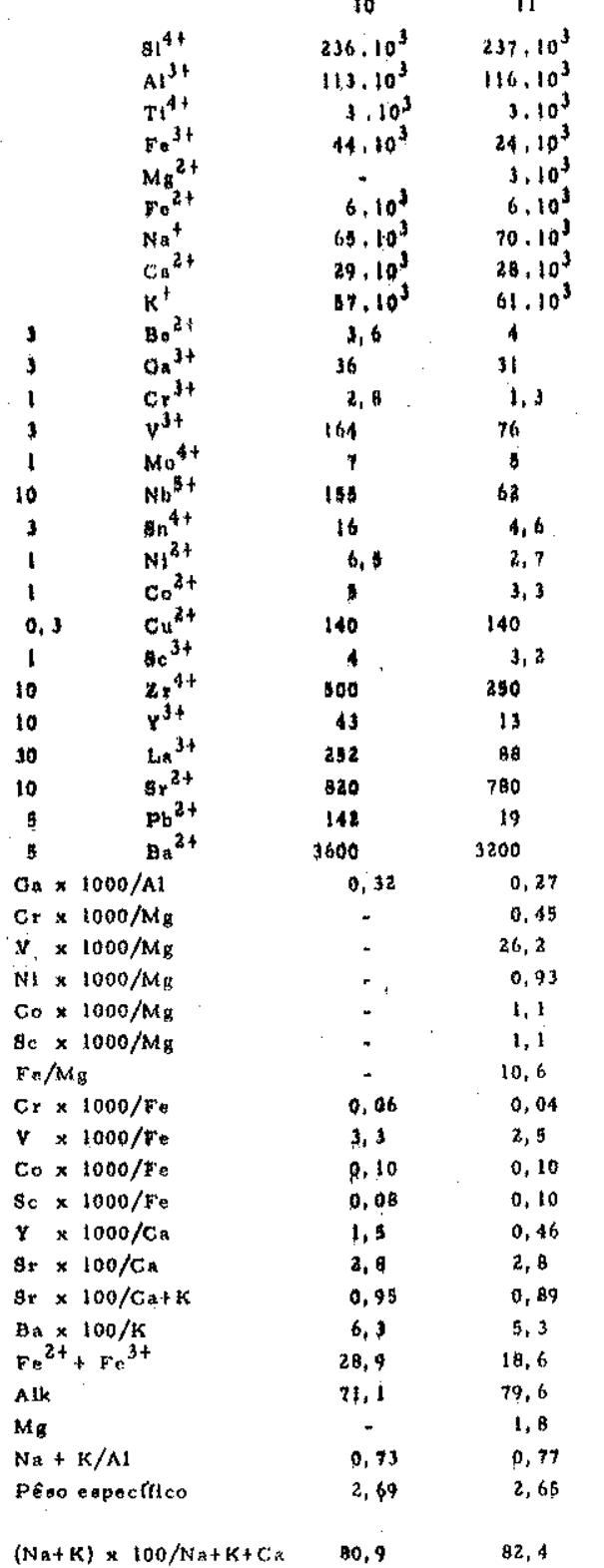

(s) timlte de nengibilldadel (nd) năo detectado;
Nofeltan sieniton

\section{I. \\ is}

$229 \cdot 10^{3}$

$123,10^{3}$

$251.10^{3}$

$105.10^{3}$

$3,10^{3}$

36,10 ?

$11.10^{3}$

$3.10^{3}$

$8,10^{3}$

$86.10^{3}$

$26,10^{3}$

$89.10^{3}$

3,6

9

70

6

4

2,4

3,3

20

$130^{\text {nd }}$

n!t

1000

19

3000

0,23

3,5
26,9

0,92

1,3

7,4

0.47

3,6

i, 7

4,3

1,3
3,8

1,2

5,0

11,5

BY, 0

1,5

0,81

2, 59

$4.10^{3}$

$6.10^{3}$

$67.10^{3}$

$\$ 4.10^{3}$

11

3,4

Bo

109

24

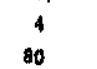

870

870
65
460
620

620
43

1080

0,26

0.05
20,0

1,3

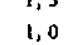

1,7

10,5

0,08

1,9
0,09

0,09
0,21

3,5

3.4

0,77

1,7

25,4

72,3

2,3

0,79

2,73

84, 7

B7, 1

(-) กão encontrada

3,1

28

70

3)

31

2
210

68
740

740

320

2,1

2,4
0,05

1,1

78,0

B7, 2
14

$254,10^{3}$
$123,10^{3}$

$1.10^{3}$

$19,10^{3}$

$1.10^{3}$

$10.10^{3}$
$58.10^{3}$

$16,10^{3}$

$50,10^{3}$

2,8

2, 7

1,6

100

5,5

320
0,22

2,1
53,8

1,2

1,5

22,4

0,09

0,05
0,07

0,34

4,6

0,64

21,0

1,0

0,57

2, 63

15

16

17

$247.10^{3}$

$139,10^{3}$
$2.10^{3}$

$19,10^{3}$

$1.10^{3}$
$1.10^{3}$

$70,10^{3}$

$12,10^{3}$

$62,10^{3}$

b.

a?

$$
{ }_{103}^{24}
$$

$10 B$

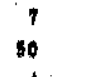

4

$1+5$
41

41

3,2
200
11

68

570

31
3200

300
0,21

0,3

31 nd

43

118

4,3
3,1

$\pi, 7$

32

nd
$350^{24}$
$360^{\text {nd }}$
17
1200

. 1,1

4,3

190

9. 5

3,1

2,1

110

3,2
450

450
36

106

370

34

200

1540
0,31

$\begin{array}{r}2,3 \\ 1401\end{array} \quad 146,6$

$5,2 \quad 5,2$

4,5

4,7

5,3

65,0

65,0

2., 1

0,07

38,3

3,8

0,12

- 0,14

1,7

$4,0 \quad 4,7$

0.74

4,7
1,2

2,5

14,6

85,0

0,4

0,70

2,70

91,7

89,9
Tinguafion

$246 \cdot 10^{3} \quad 246 \cdot 10^{3}$

$115.10^{3}$

3. $10^{3}$

4. $10^{3}$

$1,10^{3}$

$17,10^{3}$

17. $10^{3}$

$51,10^{3}$

$9,1 \quad 1$

it

1,3

4

190

190

$4,7 \quad 6$,

$3,2 \quad 4,7$

3,3

180

2, 6

440
20

170

370

03
100

0,32

1,9

$62,9 \quad 49,1$

$4,6 \quad 4,3$

$4,7 \quad 2,1$

3,7 27,

$0,05 \quad 0,04$

$1,7 \quad 1,8$

$0,12 \quad 0,07$

0.10 -

$1,6 \quad 3,9$

$3,1 \quad 6,0$

$0,53 \quad 0,94$

$0,17 \quad 0,41$

$16,4 \quad 20,0$

(13, $2 \quad 79,3$

$0.4 \quad 0.7$

$0,80 \quad 0,68$

$2,55 \quad 2,58$

i1,

93,1 


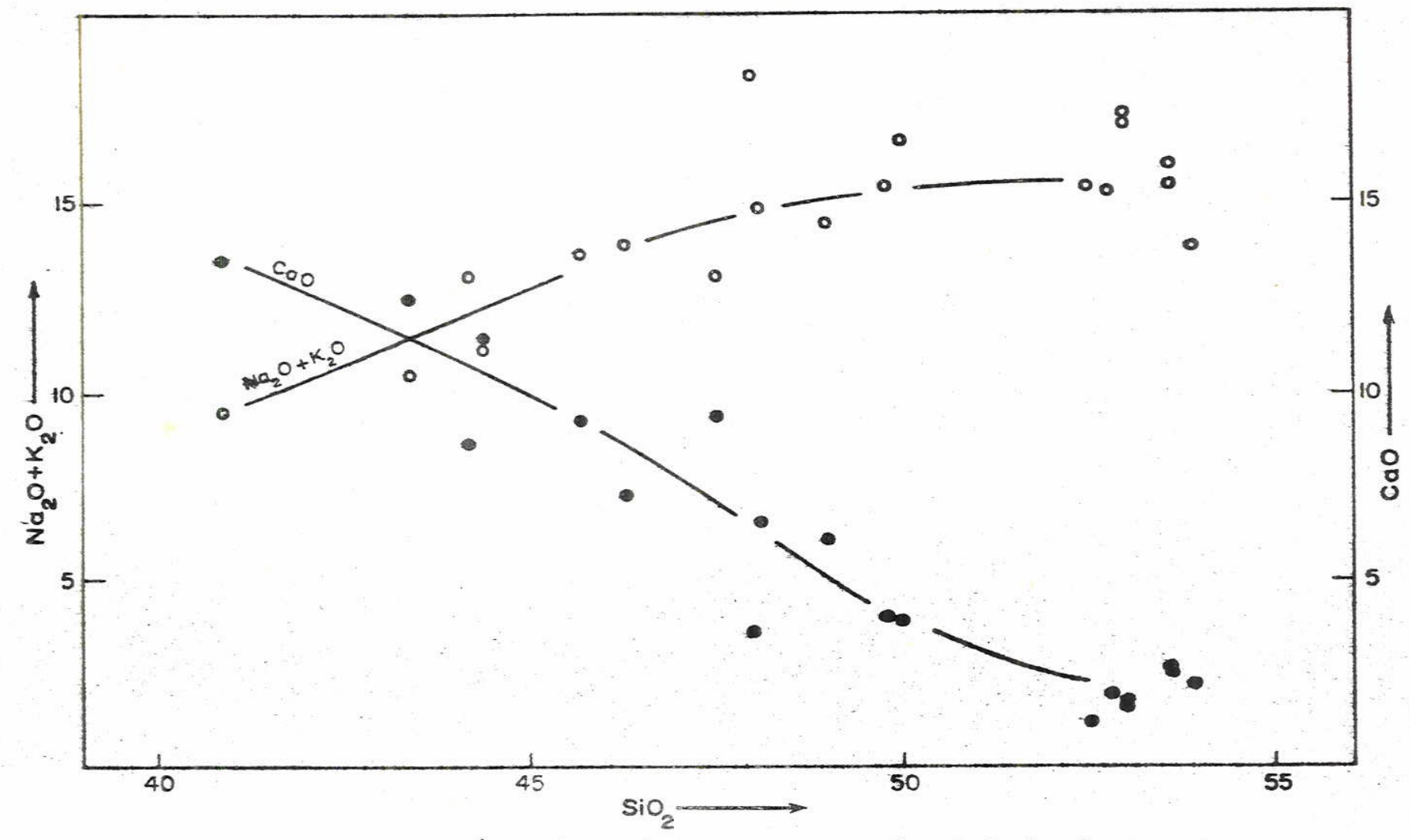

Fig. 17 - índice átcoli-cótcico das rochas alcakinas de tropircouā. 
quinta classe, a das séries hiperalcalinas, cujo índice álcali-cálcịco não excede a 46. Comparando - se os valores conseguidos por Freitas (1947, p。108) e Almeida (1955, p。134; 1961, p.166), respectiva mente, 46, 4, 45, 2 e 44, 0, para os índices álcali-cálcicos das rochas da IIha de São Sebastião, Arquipélago Fernando de Noronha e Illha de Trindade com aquêle citado acima, verifica-se ser Itapirapuã, den tre as províncias nacionais até o presente momento investigadas, a mais fortemente alcalina.

Em traços gerais, os diagramas for am elaborados segundo o esquema formulado por Nockolds e Allen (1953). Contudo, dado o caráter fortemente alcalino das rochas da província, empregamos como base de projeção, o índice félsico de Simpson (1954), ex presso pella relação

$$
F=\frac{(\mathrm{Na}+\mathrm{K}) \times 100}{\mathrm{Na}+\mathrm{K}+\mathrm{Ca}},
$$

em lugar do indice de Larsen adotado por aquêles Autores. Os dados utilizados na construção dos vários diagramas foram extraídos das Tabelas XXVa e XXVb.

O gráfico da Fig. 18, reunindo pêso específico e Indice félsico das rochas investigadas, mostra que a densidade decres ce regularmente com o aumento do Índice de Simpson (1954). Uma rápida verificação permite notar que, dentro da série estudada, o pêso específico passa de um valor máximo de 2,91, no biotita melágtigito, a um mínimo de 2, 55, no tinguaíto.

O diagrama da Fig. 19 mostra a distribuição dos e lementos traços, incluindo as médias aritméticas determinadas, para as rochas de Itapirapuã, à exceção dos carbonatitos (A), de Magnet Cove, Arkansas, E.U.A. (B), alcalinas do Brasil (C), exclusive Itapi rapuã e alcalinas mundiais (D). Os dados sôbre as rochas de Magnet Cove e do Brasil foram extraídos, respectivamente, dos trabalhos de Erickson e Blade (1963) e Guimarães e Dutra (1962), excluindowse, contudo, dêste último os valores referentes às províncias oceänicas . visto que a totalidade dos dados existentes na literatura dizem respeito às alcalinas continentais. Os dados relativos às alcalinas mundiais foram compilados pelo autor do presente trabalho a partir das se guintes fontes: Butler (1954), Butler e Smith (1962), Degenhardt (1957), 


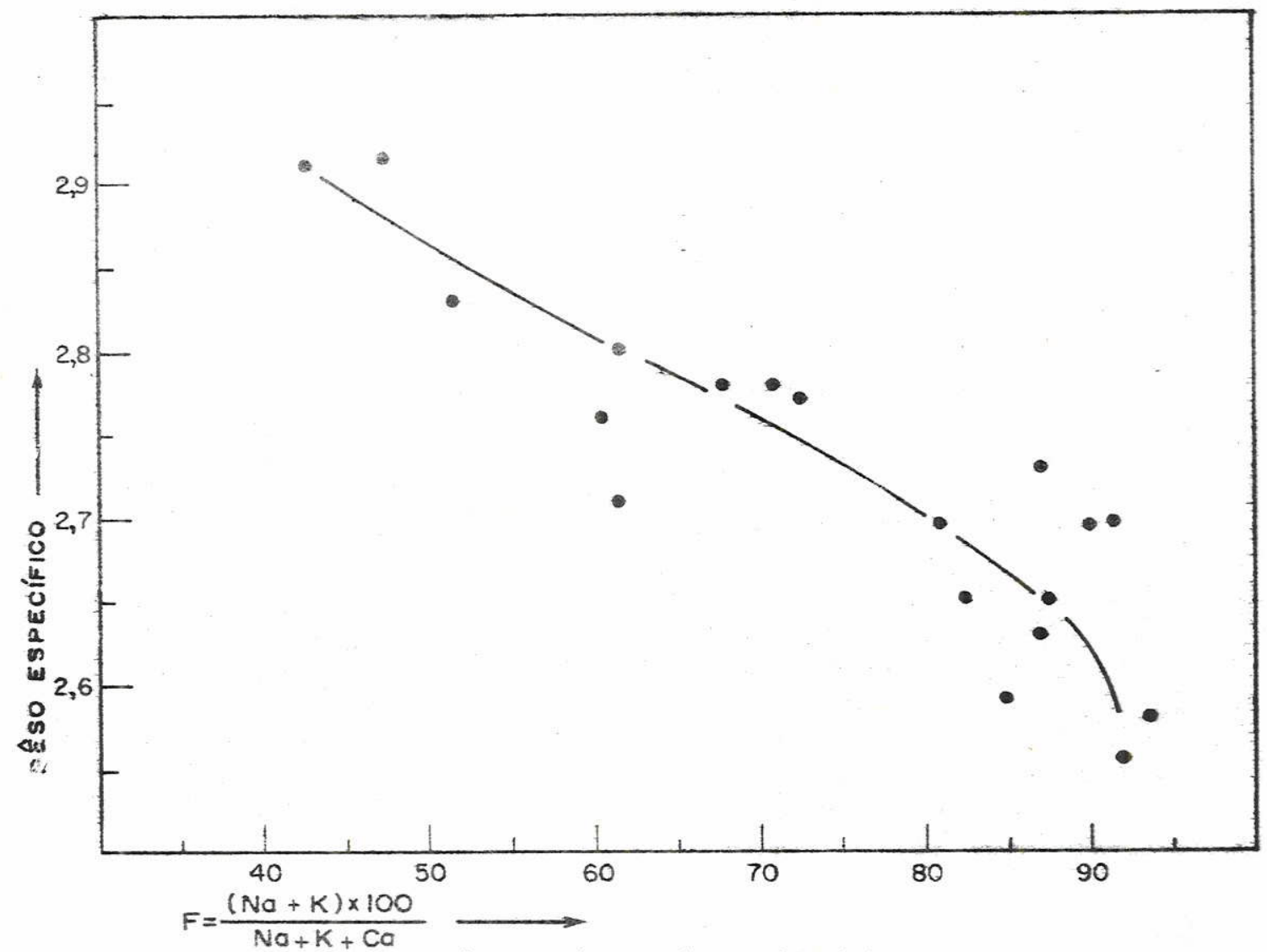

Fig.18- Grafico relacionando o pêso específico e $o$ índice fétsico $(F)$ das rochas de trapirapuā. 


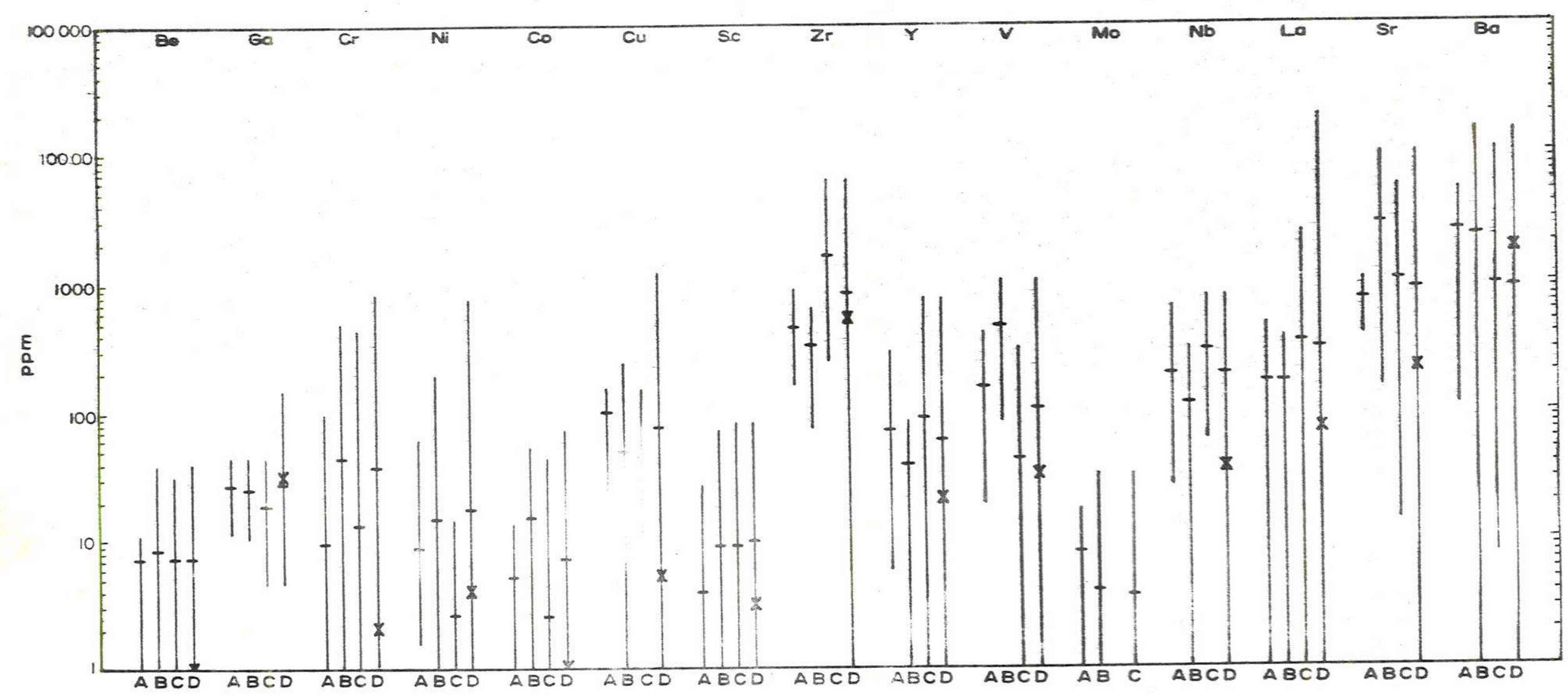

Fig. 19-Grofico mostrondo o variaçōo no conteúdo em elementos traços das rochas de itadirapuā (A), Magre - Cave (E); alcalinos brasileircs (C) e mundiois (D). Os valores médios, determinodos paro codo elementc, estāo assinnlacios por um pequeno traso horizontol. Umo segundo média, obtido por Turekian e wedepohl (1961) e representadc por uma marca no formo de cruz, é fornecida paro as rochas alcalinas mundiois. 
Erickson e Blade (1963), Gerasimovskii e Belyayev (1963a), Gerasi movskit e Belyayer (1.963b), Gordon e Murata (1952), Guimarães e Du tra (1962), Heier (1964), Hewitt (1960), Siedner (1965), Temple e Grogan (1965), Turekian e Kulp (1956), Upton (1960), Yeremenko, Walter e Klimenchuk (1963). Dois valores médios são fornecidos para as alcalinas mundiais, sendo o primeiro dêles correspondente à média aritmética dada por Turekian e Wedepohl (1961; assinalada por uma marca na forma de cruz) e o segundo, referente à médía conseguida por C.B.G。, utilizando os dados que constam das fontes acima cita das. A precariedade dos dados utilizados por Turekian e Wedepohl (1961) levou o autor da presente obra a executar um trabalho compilativo com vistas à obtenção de um valor médio que melhor refletisse a concentração dos vários elementos nesse grupo particular de ro . chas.

O diagrama triangular $\mathrm{Fe}: \mathrm{ALK}: \mathrm{Mg}$, onde $\mathrm{Fe}=$
$\mathrm{Fe}^{2+}+\mathrm{Fe}^{3+}$ e Alk $=\mathrm{Na}+\mathrm{K}$ é dado na Fig. 20 e foi obtido a partir de dados contidos nas Tabelas XXVa e XXVb. A curva obtida, com a sua concavidade voltada para o vértice $\mathrm{Mg}$, tem um comportamento carac terizado por acentuado enriquecimento em álcalis, em detrimento de ferro e magnésio. O empobrecimento dêste último faz-se de maneira tão drástica, que chega a existir, dentro da província, rochas intei ramente desprovidas de magnésio.

Os diagramas de variação dos elementos princi pais, traços e algumas de suas relações com o índice félsĭco estão re presentadas nas Figs. 21 a 26. A análise do comportamento do vám rios elementos, uncluindo os dados relativos aos carbonatitos (Tabela XXI), será feíta no ítem seguinte. Os valores fornecidos para raio iô nico (em Angstrom), eletronegatividade e potencial. de ionização (em volts), for am extraídos respectivamente, dos trabalhos de Ahrens (1952), Gordy e Thomas (1956) e Moore (1958).

$$
\text { Distribuição dos elementos }
$$

\section{Silício e Oxigênio}

Ambos os elementos crescem linearmente ao longo da série (Fig. 21), com a relação Si:O passando de 1:2, no extremo máfico da curva, a $1: 1,8$, na sua parte félsica. O conteúdo em $O$ des - 


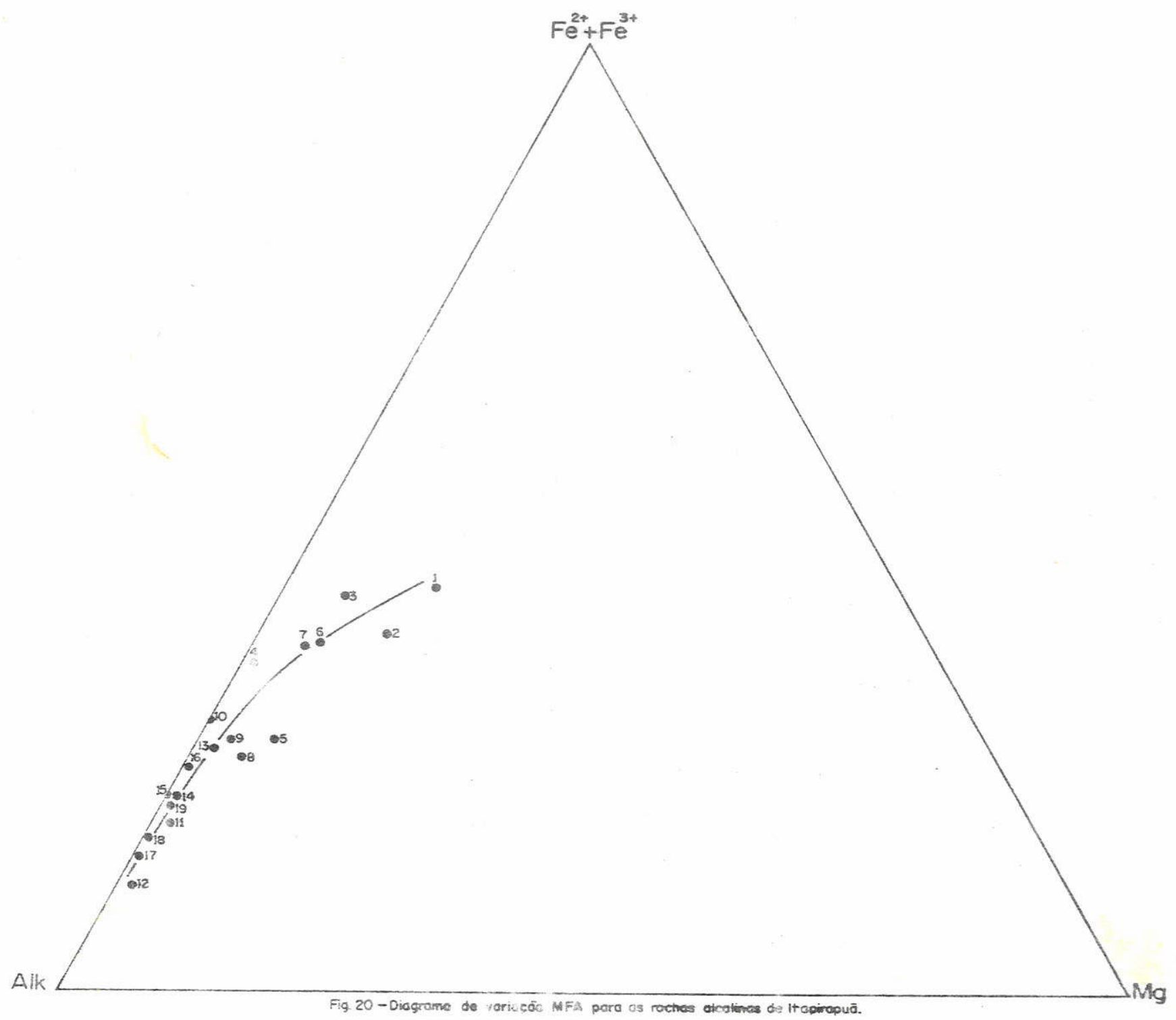




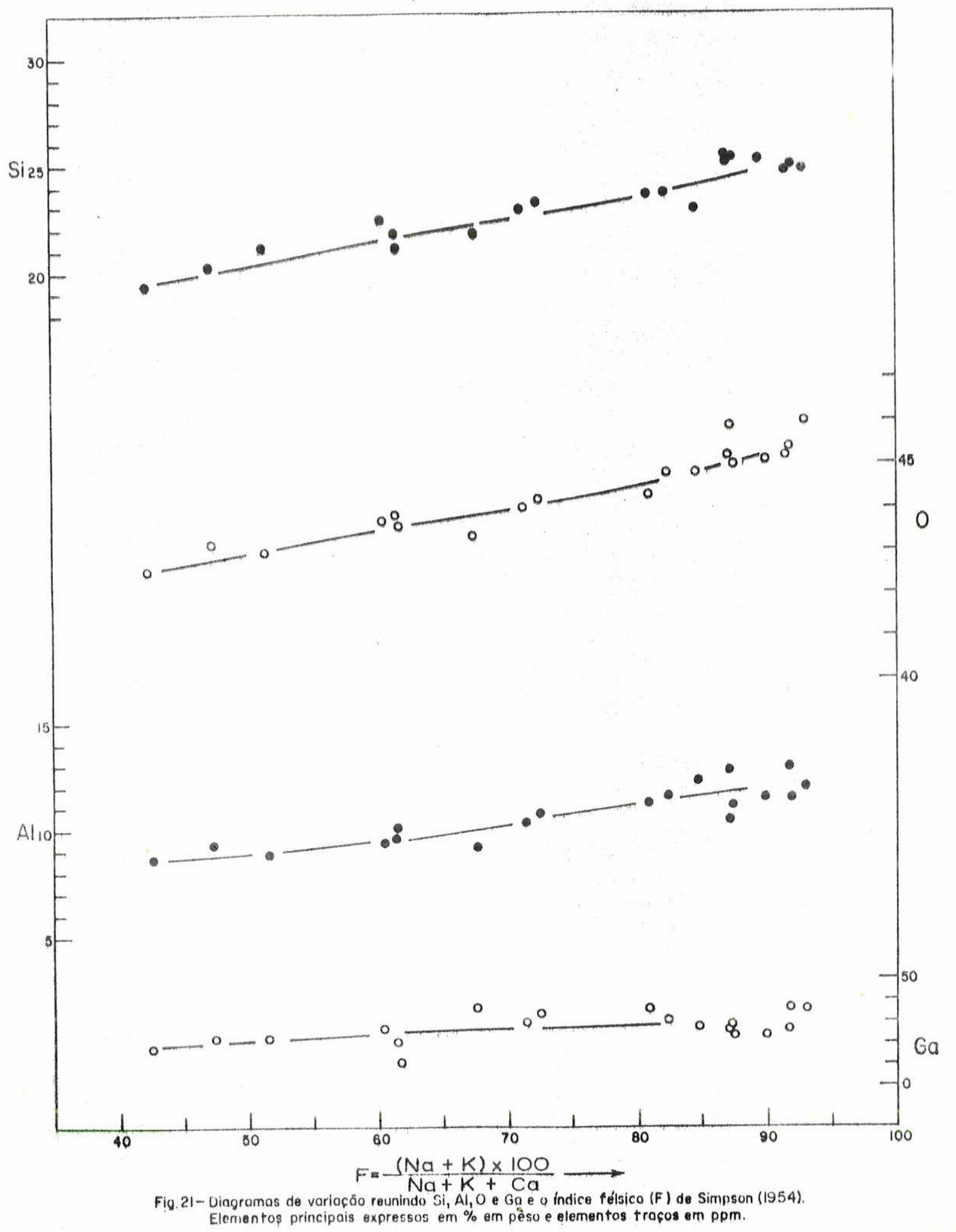




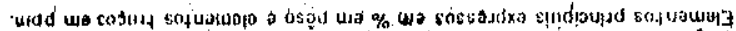

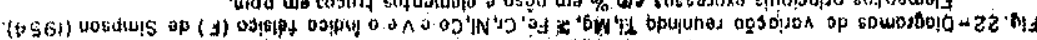

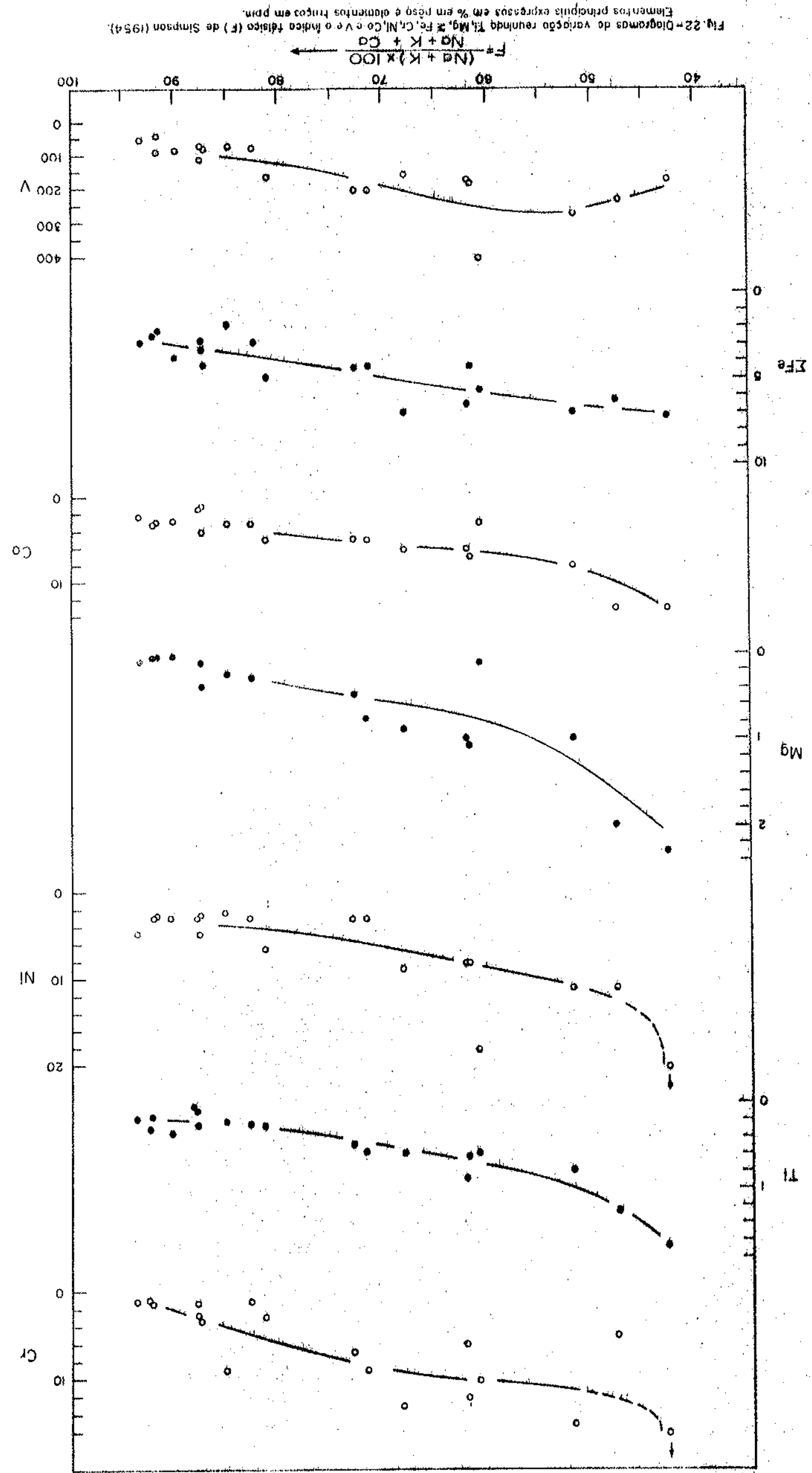




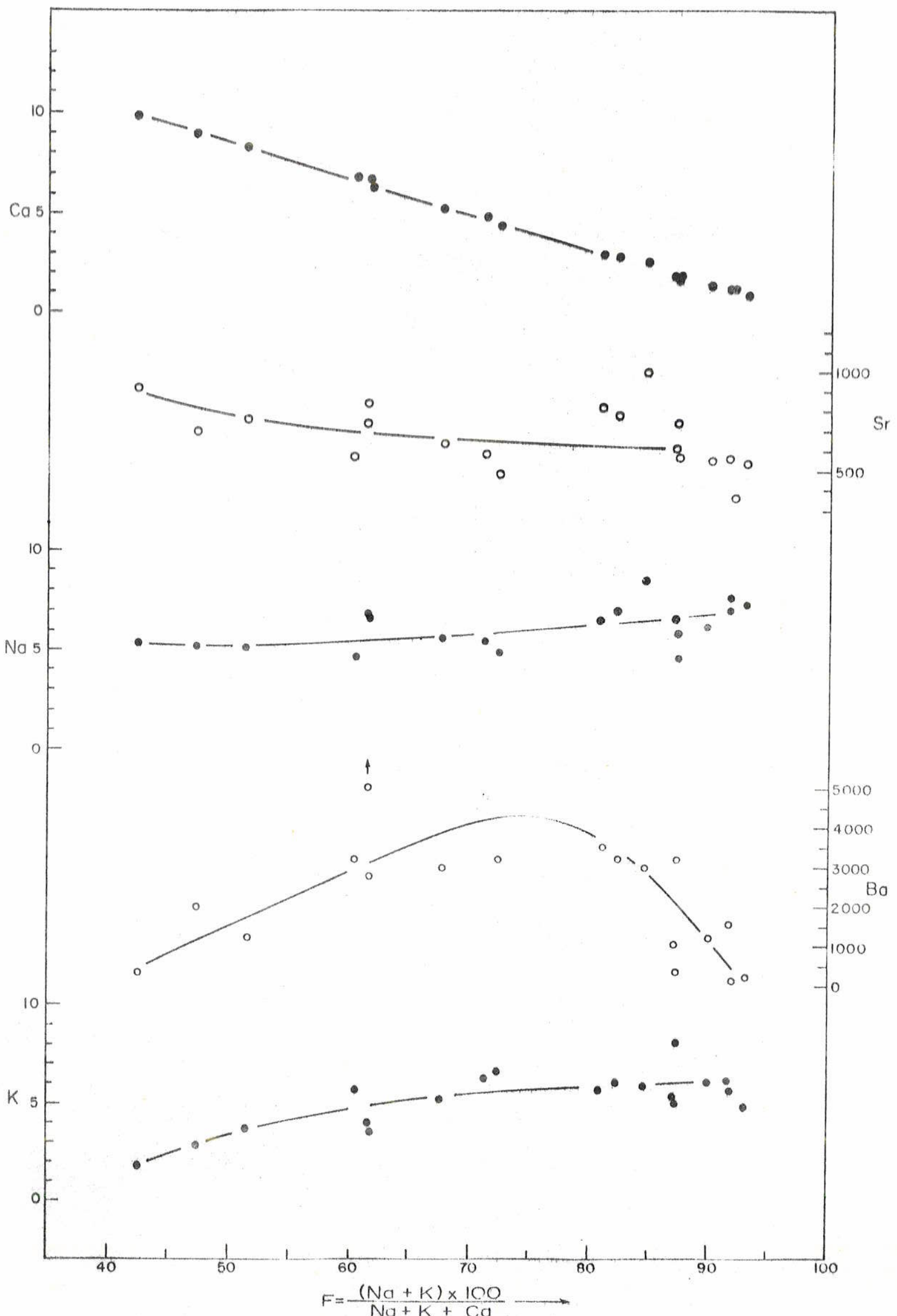

Fig. 23-Diuqrumus df varię̧üo reunindo Co. Na, K, Sre Bae o indice felsico (F) de Simpson (1954)

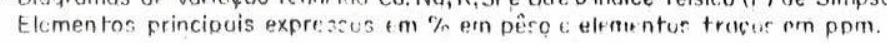




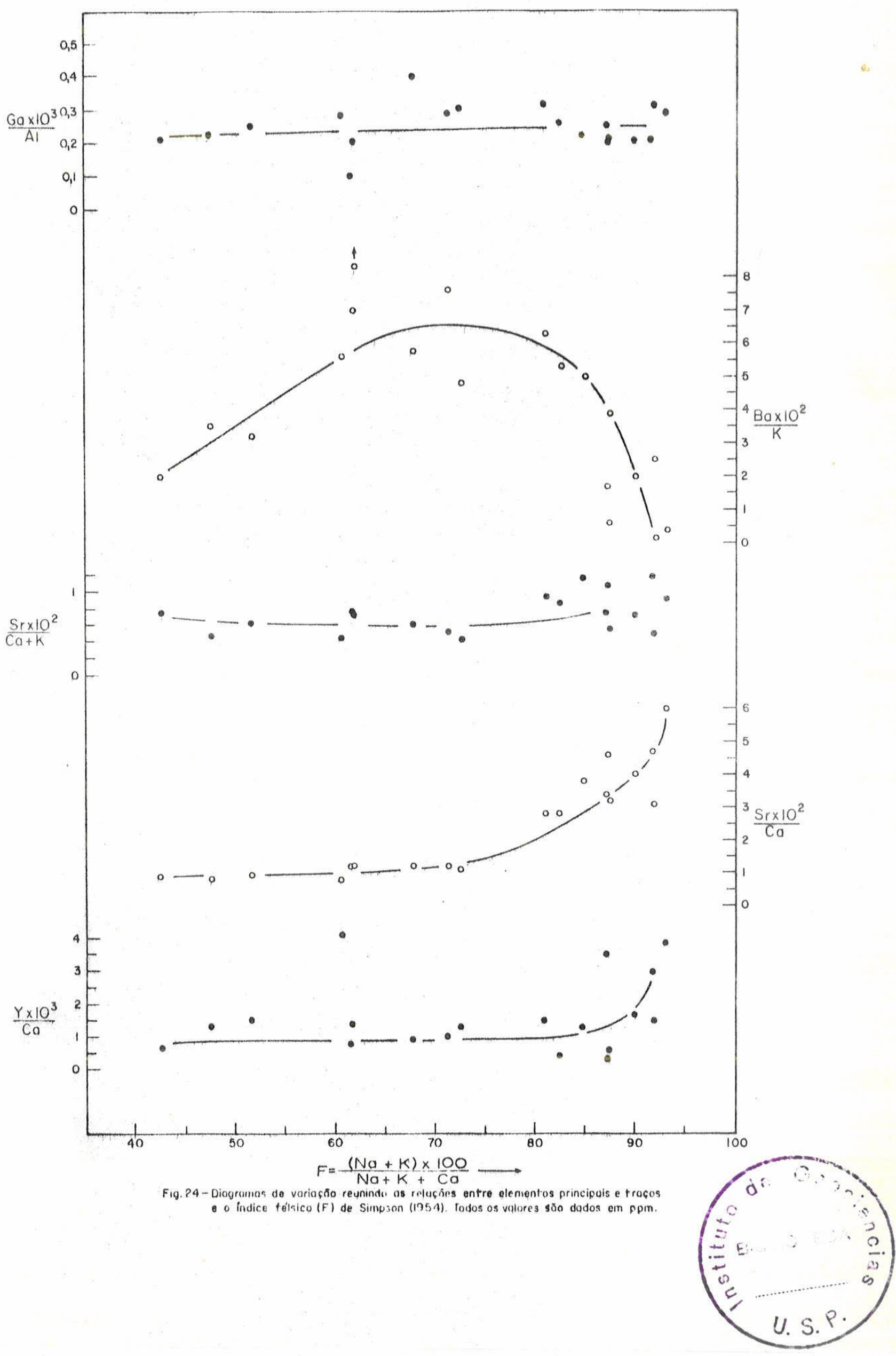




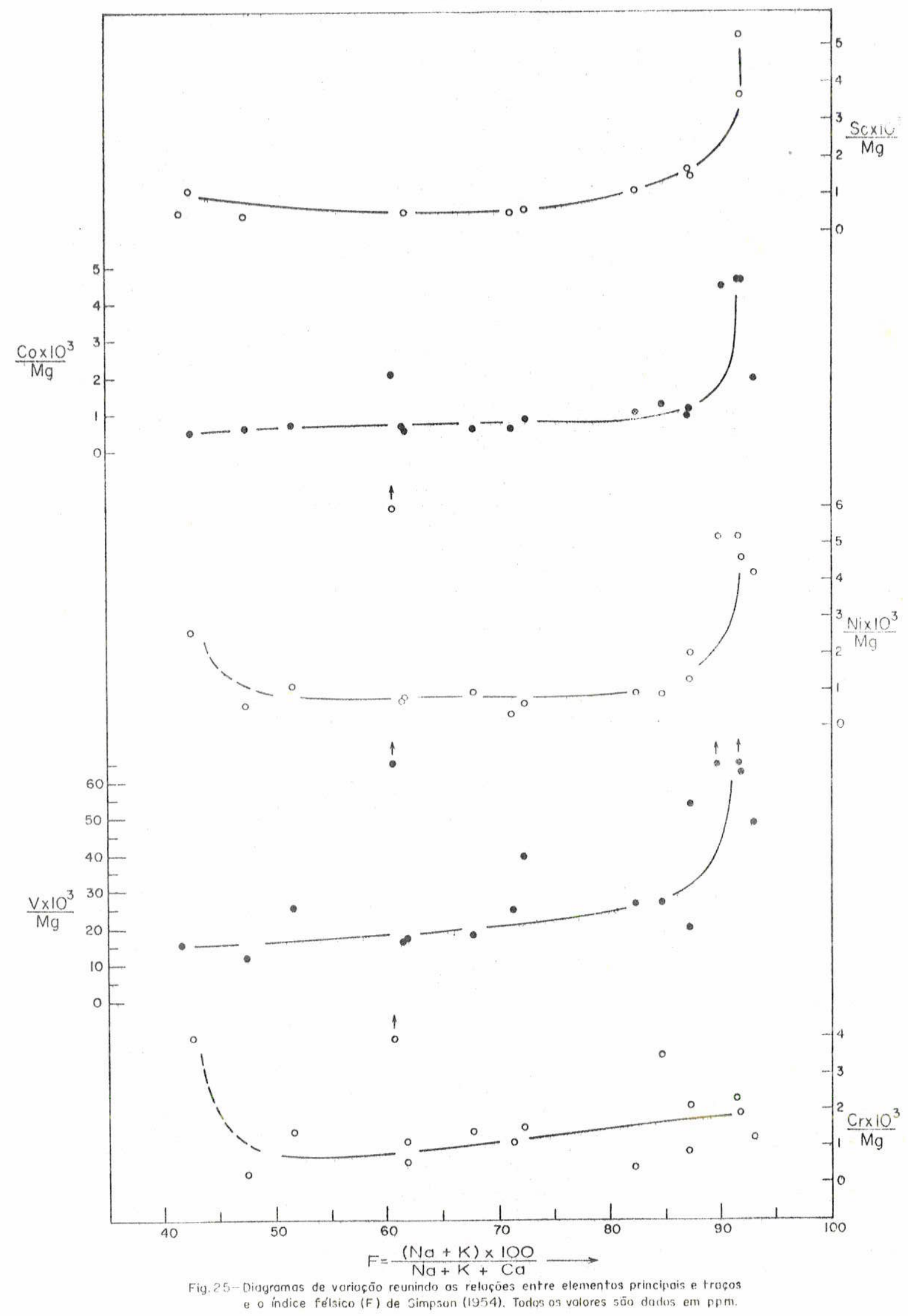




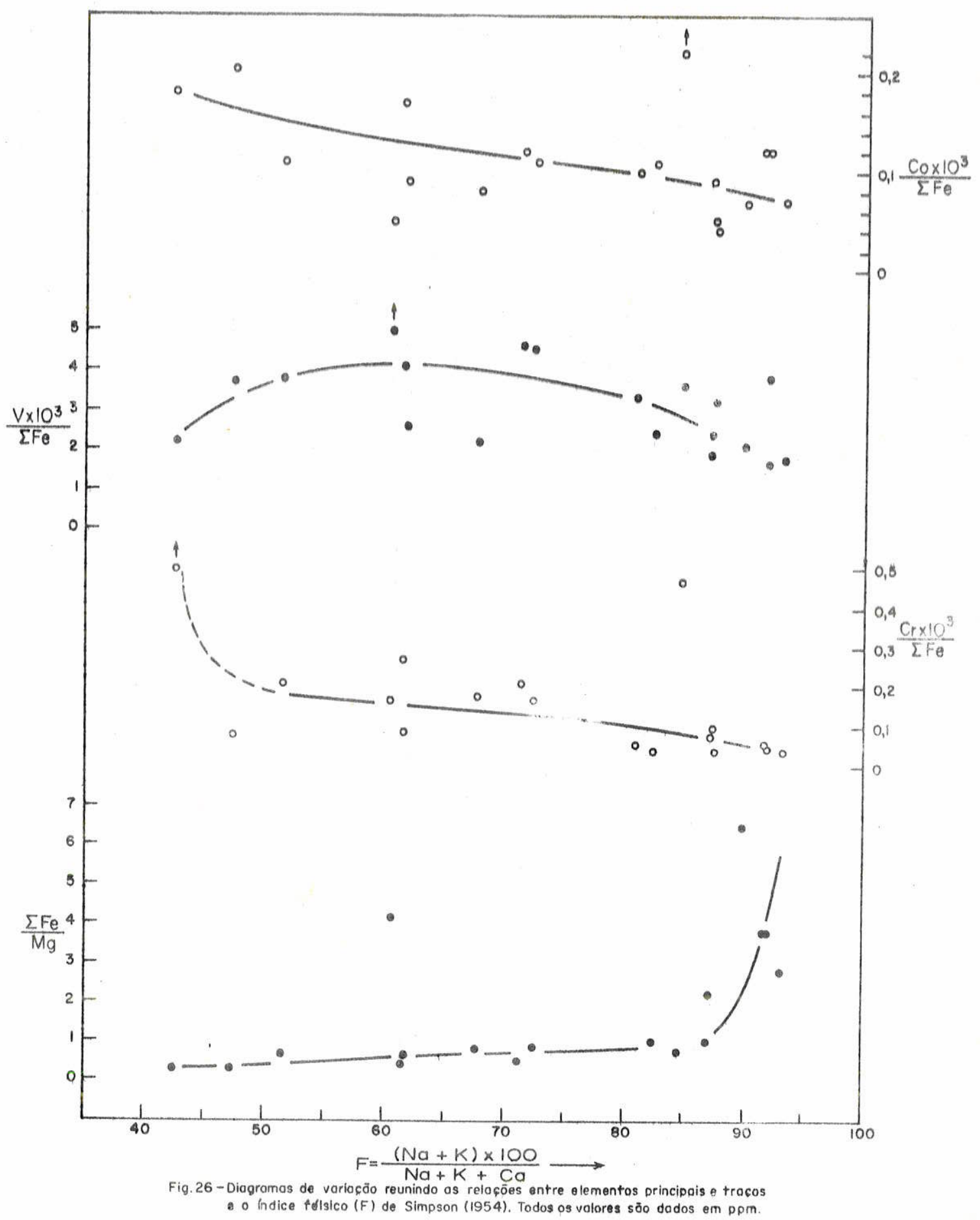


sas rochas não é fornecido nas Tabelas XXVa e XXVb, todavia, pode ser obtido diretamente das mesmas, subtraindo se de 100 a propor. ção total dos cátions presentes.

Aluminio e Gálio

A curva do alumínio (Fig. 21) mostra razoável pa ralelismo com as do silício e oxigênio, enquanto que a do gálio cres-

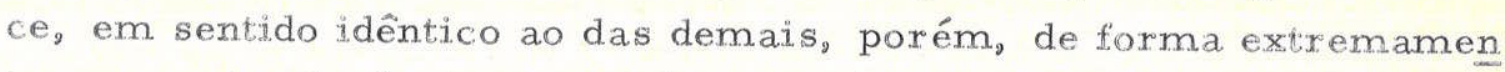
te suave. A relação $\mathrm{Ga} \times 1000 / \mathrm{Al}$, variável de 0,11 a 0,40 e tendo em 0,25 o seu valor médio, tem um comportamento prâticamente horizon tall através da série, como se vềna Fig. 24. O aumento progressivo na concentração de $\mathrm{Ga}$, caminhando das rochas mais båsícas às mais ácidas da província, favorece as conclusões alcançadas por Goldsch midt e Peters (1931), Shaw (1957), Borisenok (1959) e Siedner (1965), que advogam a idéía de que êsse elemento é acumulado no curso da cristalização fracionada.

A coerência geoquímica entre os pares $\mathrm{Ga}^{3+} \mathrm{e}$ $\mathrm{Al}^{3+}$ e $\mathrm{Ga}^{3+}$ e $\mathrm{Fe}^{3+}$, como apontada por Taylor $(1966, \mathrm{p} .181$ ) e atri. buída à simillaridade dos valores do raio iônico $\left(\mathrm{Ga}^{3+}=0,62 ; \mathrm{Al}^{3+}=\right.$ $=0,51$ e $\left.\mathrm{Fe}^{3+}=0,64\right)$ e potencial de ionização $\left(\mathrm{Ga}^{3+}=30,7 ; \mathrm{Al}^{3+}=\right.$ $\left.28,4 \mathrm{e} \mathrm{Fe}^{3 t}=30,6\right)$, leva-nos a acreditar que êsse elemento está presente nas rochas de Itapirapuã associado principalmente a dois gru pos de minerais: a) grupo félsico, constituído de feldspatos e feldspa tóides, quałśdo então substitui a $\mathrm{Al}^{3+}$ e b) grupo máfico, representado por magnetita, piroxềnos e granadas, quando entäo ocupa a posi ção do $\mathrm{Fe}^{3+}$.

O campo de variação do gálio para as rochas anali sadas de Itapir apuã é simillar ao mostrado pelas rochas de Magnet Co ve e situa-se dentro do estabelecido para as alcalinas mundiais (Fig. 19). Os teores médios de Ga obtidos deram os seguintes valores: 28 ppm para Itapirapuã (média aritmética de 22 análises) e 27 ppm para Magnet Cove, enquanto que as médias calculadas para as alcalinas mundiajs acusaram 30 (ef. Turekian e Wedepohl, 1961) e 28 ppm (cf. dados por nós coligidos). O teor médio para as alcalinas brasileiras é de 18,5 ppm.

O teor médio em $\mathrm{Ga}$ dos carbonatitos de Itapirapuã, 
$12,5 \mathrm{ppm}$ (Tabela XXI), é inferior ao dos demais grupos de rochas da província (ver Tabela XXVI). Tal fato não constitui surprêsa face àna tureza essencialmente carbonática do material residual. Nos carbona tilos, Ga ${ }^{3+}$ associa-se aos feldspatos e ocupa a posição do $\mathrm{Al}^{3+}$ na es trutura dêsses minerais. O conteúdo elevado em gálio das rochas de Itapirapuã (12,5 ppm), reflexo da presença de feldspatos (Tabela XX), situa-se acima dos valores fornecidos pox Gold (1966) para a sua composição "média" e "típica" de carbonatitos, respectivamente 2, 6 e 2, 4 ppm (Tabela XXII)。

\section{Titânio}

A curva do titânio, após sofrer uma queda brusca no seu extremo máfico, mostra um decréscimo menos acentuado e regular com o aumento do índice félsico (Fig. 22). Titânio concentra -se, prâticamente, em todos os minerais escuros existentes nessas rochas (itianita, piroxênios, magnetita, etc.) e especialmente nas granadas, variedade melanita, onde representa um dos seus principais componen tes quimicos.

Magnésio e Ferro

O teor em magnésio das rochas de Itapirapuã dimi nui à medida que o seu índice félsico aumenta, o mesmo sucedendo com o conteúdo em ferro total (Fig. 22); contudo, enquanto a curva do ferro decresce de modo uniforme, a do magnésio o faz de forma distin. $t a$, tendo como característica principal um declive bem mais acentua do nos primeiros estádios de seu desenvolvimento. A relação Fe total/ /Mg, representada na Fig. 26, aumenta suave e progressivamente em direção ao extremo félsico da série até a altura do índice 85, quando en tão sofrendo forte curvatura termina por crescer bruscamente até o fina1. Essa inflexão, refletindo concentração relativa de Fe nos resíduos magmáticos e decorrente do conteúdo extremamente baixo em magné sio das rochas mais félsicas da série, vai se constituir numa feição co mum à quase totalidade dos diagramas que tomam $\mathrm{Mg}$ como divisor de correlação. 
Vanádio

De um teor inicial de 168 ppm, no biotita melteigito, êste elemento cresce ao longo da série atẻ atingir a concentração máxima de $400 \mathrm{ppm}$ na altura do índíce 60, quando então começa a decrescer regularmente até o extremo félsico (Fig. 22)。A relação $\mathrm{V} \times 1000 / \mathrm{Fe}$ total, dada na Fig. 26, comporta-se de forma similar à curva do V, ao passo que a V $\times 1000 / \mathrm{Mg}$, representada na Fig。25, tem um traçado semelhante ao da curva Fe total/Mg。 O comportamento do vanádio, caracterizado por um aumento progressivo nos primeiros es tádios de evolução da série, é feição comum à quase totalidade das prô víncias que integram a série alcalina de Nockolds e Allen (1954)。 No presente caso, êsse aumento é devido à cristalização de magnetita e melanita nas rochas maís básícas da província, acarretando, conse quentemente, um empobrecimento contínuo no conteúdo de vanádio do magma. Nas fases mais avançadas de evolução da série, êsse elemen to associa-se principalmente aos minerais do grupo dos piroxênios. A concentração de vanádio, presente na forma de $\mathrm{V}^{3+}$, junto aos mine rais citados resulta de sua grande afinidade química com $\mathrm{Fe}^{3+}$, como evidenciado na semelhança de carga e raio iônico $\left(\mathrm{V}^{3+}=0,74, \mathrm{Fe}^{3+}=\right.$ $=0,64)$. Não obstante o maior raio iônico, $\mathrm{V}^{3+}$ tem eletronegativida de bem menor que a do $\mathrm{Fe}^{3 t}\left(\mathrm{~V}^{3+}=1,4 ; \mathrm{Fe}^{3+}=1,8\right)$, o que the possibilita ocupar a posição do $\mathrm{Fe}^{3+}$ na estrutura dos mineraỉs. A coerên. cia geoquímica entre $\mathrm{V}^{3+}$ e $\mathrm{Fe}^{3+}$ é demonstrada no diagrama de variação da Fig. 27.

O teor médio em $V$ das rochas analisadas de Itapi rapuã é da ordem de 145 ppm e portanto bem superior aos valores obtidos para as alcalinas brasileiras, 41 ppm, e alcalinas mundiais, 30 e 95 ppm, respectivamente, segundo Turekian e Wedepohl e dados por nós compilados. A maior abundância em vanádio das rochas da provín cia de Magnet Cove sôbre as demais está evidenciada no campo de variação dêsse elemento, representado na Fig. 19, onde o valor médio assinalado é de $425 \mathrm{ppm}$.

Vanádio está presente em pequena quantidade nos carbonatitos de Itapir apuã. O seu teor médio nessas rochas, da or dem de 37 ppm (Tabela XXI), mostra-se inferior aos valores encon trados para os demais grupos de rochas da provincia (ver Tabela 
$-106-$

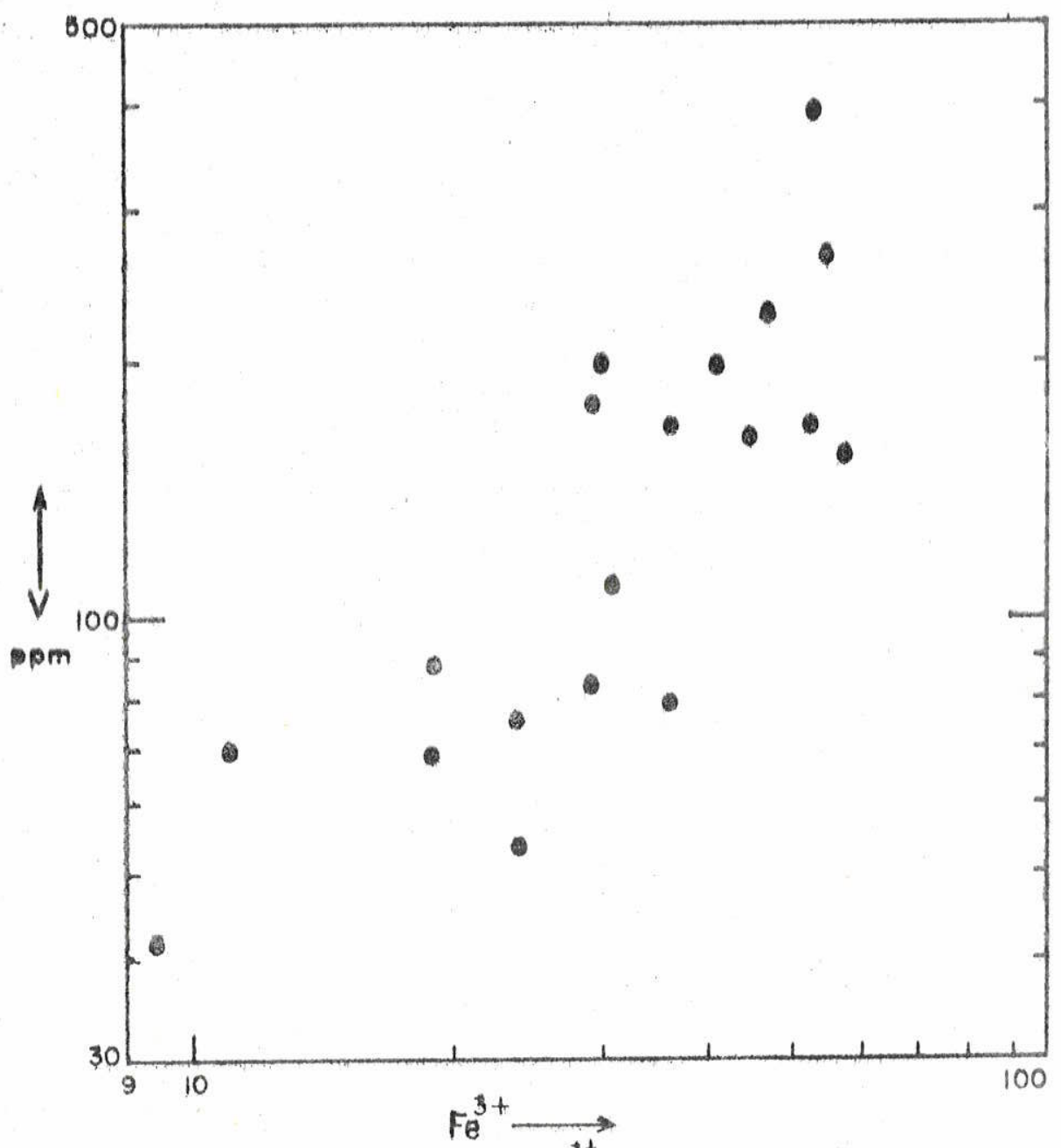

Fig. 27 - Relaça antre $\vee$ e $\mathrm{Fa}^{3+}$ nas rachas de Itopirapua. 
XXVI)。É consideràvelmente menor que os valores obtidos, seja para as rochas dos distritos de Magnet Cove (200 ppm) e Kaiserstuhl (150 ppm), seja para a composição "média" e "típica" de Gold, em ordem 94 e 105 ppm (Tabela XXI). $\mathrm{V}^{3+}$ concentra-se nos carbonatitos junto à. magnetita, onde ocorre substituindo a $\mathrm{Fe}^{3+}$.

Crômio

O comportamento do crômio, representado na Fig. 22, é marcado por um decréscimo constante, a princípio algo abrupto, indo-se dos têrmos mais básicos da série àqueles portadores de maior Índice félsico. Traçado similar é exibido pela relação Cr x 1000/Fe to tal (Fig. 26); já a relação Cr x 1000/Mg (Fig. 25) mostra um rápido declínio no seu início, seguido de crescimento regular até o final da série. Um comportamento antagônico para as relações $\mathrm{Cr} / \mathrm{Fe}$ total e $\mathrm{Cr} / \mathrm{Mg}$ e idêntico ao presente caso foi também observado por Siedner (1965, p. 119) em seu estudo sôbre a geoquímica das rochas do complexo alcalino de Paresis no sudoeste da Âfrica.

Os valores quase idênticos do raio iônico $\left(\mathrm{Cr}^{3+}=\right.$ 0,$\left.63 ; \mathrm{Fe}^{3+}=0,64\right)$, eletronegatividade $\left(\mathrm{Cr}^{3+}=1,6 ; \mathrm{Fe}^{3+}=1,8\right)$ e po tencial de ionização $\left(\mathrm{Cr}^{3+}=31,0 ; \mathrm{Fe}^{3+}=30,6\right)$ sugerem que êsses e lementos ocorrem na natureza em as sociação Íntima, sendo sua coerên cia geoquímica um fato amplamente aceito na literatura. Contudo, a distribuição de $\mathrm{Cr}^{3+}$ e $\mathrm{Fe}^{3+}$ nas rochas de Itapir apuã não mostra qual quer traço indicativo dessa coerência e o diagrama elaborado e não publicado apresenta uma grande dispersão nos pontos projetados. Sied nex (1965, p. 119), defrontando-se com problema análogo, interpretou. a ausência de linearidade no diagrama de variação dêsses elementos como resultante da oxidação imprevisível do ferro ferroso, mascaran do por completo a relação $\mathrm{Cr}^{3+}-\mathrm{Fe}^{3+}$ A maior concentração de crômio nas rochas mais básicas da província é explicada pela faculdade dêsse elemento, dada a sua menor eletronegatividade, de ocupar a posição do $\mathrm{Fe}^{3+}$ na estrutura dos minerais (magnetita, melanita e piro xênios). Já o decréscimo contínuo no conteúdo de crômio ao longo da série resulta de sua tendência ao esgotamento no líquido magmático. Wager e Mitchell (1951, p. 184) mostraram que a concentração mais e levada em crômio das rochas da intrusão básica de Skaergaard está li 
gada principalmente aos piroxênios magnesianos e, em menor escala, aos espinélios, e que os piroxênios ferríferos e magnetita de forma. ção tardia são, pràticamente, desprovidos dêsse elemento em sua com posição, evidenciando o esgotamento precoce de $\mathrm{Cr}$.

O teor médio em Cr para as rochas alcalinas anali sadas de Itapirapuã, 9,3 ppm, é superior ao valor fornecido por Ture kian e Wedepohl, 2 ppm, para as alcalinas muidiais e não muito dis crepante daquele relativo às alcalinas brasileiras, 13 ppm (Fig. 19): contudo, situa-se muito aquém dos obtidos para as rochas de Magnet Cove, $43 \mathrm{ppm}$, e alcalinas mundiais, $37 \mathrm{ppm}$, segundo os dados por nós coligídos.

O conteúdo médio em $\mathrm{Cr}$ dos carbonatitos de Itapirapuã, 15,5 ppm (Tabela XXI) é superior ao teor dêsse elemento para tôdas as rochas da província, a exceção do biotita melteigito. Esta. comprovação, aliada ao fato de que a concentração dêsse elemento de cresce de forma regular passando-se das variedades maís básicas às mais ácidas da série (Fig. 22) parece indicar que o comportamento do crômio nas rochas investigadas é anômalo. Anomalia no comportamen to dêsse elemento acarretando sua concentração em soluções residuais, foi primeiramente observada por Wager e Mitchell (1951, p. 183) em estudo sổbre a geoquímica da intrusão básica de Skaergaard e discutida com pormenores por Ringwood (1955b, pp.248-249). Segundo êste Autor, o $\mathrm{Cr}^{3+}$, assim como o $\mathrm{V}^{3+}, \mathrm{Sc}^{3+}$ e $\mathrm{Ni}^{2+}$, visto que êsses ele mentos podem também excepcionalmente concentrar-se em soluções residuais, tem seu comportamento no magma condicionado no grau de polimerização do mesmo. Em magmas ricos em voláteis, os íons men cionados, ao lado do comportamento normal, podem vir a se concentrar junto às soluções residuais.

O teor médio em $\mathrm{Cr}$ dos carbonatitos de Itapirapuã $(15,5 \mathrm{ppm})$ é inferior, a exceção do carbonatito de Magnet Cove, aos valores encontrados para as rochas de Kaiserstuhl (18 ppm) e compo sição química "média" e "típica" de Gold, respectivamente 66 e 102 ppm (Tabela XXII)。

Níquel e Cobalto

Estes elementos seguem a sua distribuição nor - 
mal, mostrando se fortemente concentrados nas rochas básicas e pre sentes em quantidades muito pequenas nas rochas mais félsicas. Em detalhes, contudo, o comportamento de Ni parece diferir, em certos aspectos, daquele do Co (Fig. 22), onde a curva do níquel cai mais rà pidamente no seu início que a correspondente ao cobalto. A curva da relação Ni x 1000/Mg (Fig. 25), admitido ligeiro declínio no seu extre mo máfico, comporta-se como a curva $\mathrm{Fe}$ total/Mg. A curva da relação Co x $1000 / \mathrm{Mg}$, constando também da figura anterior, é idêntica à do Fe total/Mg。A curva Co x 1000/Fe total, dada na Fig.26, com. porta-se de forma antagônica às anteriores e tem como característi ca principal um decréscimo contínuo no sentido do extremo félsíco da sérìe.

$\mathrm{Ni}^{2+}$ " tem raio iônico intermediário ao do $\mathrm{Mg}^{2+} \mathrm{e}$ $\mathrm{Fe}^{2+}\left(\mathrm{Ni}^{2+}=0,69: \mathrm{Mg}^{2+}=0,66 ; \mathrm{Fe}^{2+}=0,75\right)$, estando portanto apto a substituílos nos retículos cristalinos, contudo, os valores do po tencial de ionização $\left(\mathrm{Ni}^{2+}=18,1 ; \mathrm{Fe}^{2+}=16,2\right.$ e $\left.\mathrm{Mg}^{2+}=15,0\right)$ e ele tronegatividade $\left(\mathrm{Ni}^{2+}=1,8 ; \mathrm{Fe}^{2+}=1,6\right.$ e $\left.\mathrm{Mg}^{2+}=1,2\right)$ sugerem que $\mathrm{Ni}^{2+}$ associa-se mais a $\mathrm{Fe}^{2+}$ do que a $\mathrm{Mg}^{2+}$. Não obstante, verifica - se que essa assertiva não é inteir amente válida, visto que outras va. ríáveis, como ponto de fusão dos óxidos e caráter iônico das ligações $\mathrm{Ni} \backsim \mathrm{O}, \mathrm{Mg} \backsim \mathrm{O}$ e $\mathrm{Fe} \backsim \mathrm{O}$, parecem também exercer influência marcante no comportamento dêsses elementos (Taylor, 1966, p.173). Mais provàvelmente, como foi apontado por Siedner (1965, p. 122), $\mathrm{Ni}^{2+}$ substi tui a $\mathrm{Mg}^{2+}$ e $\mathrm{Fe}^{2+}$ na estrutura dos minerais, mostrando apenas uma preferência estatística temporária por um ou outro, dependendo das condições físico químicas prevalecentes.

A coerência geoquímica entre $\mathrm{Co}^{2+}$ e $\mathrm{Mg}^{2+}$ nas rochas investigadas é destacada na Fig。28.Co ${ }^{2+}$, a julgar pelo tama nho do seu raio iônico $\left(\mathrm{Co}^{2 t}=0,72\right)$, deveria mostrar uma associa. ção mais íntima com $\mathrm{Fe}^{2+}$ do que com $\mathrm{Mg}^{2+}$, contudo, a covariação Co-Mg é mais forte (Sandell e Goldich, 1943; Nockolds e Mitchell, 1948; Siedner, 1965) e predomina sôbre a Co-Fe, segundo Carr e Ture kilan (1961), na maioria das rochas ígneas.

O comportamento relativo do Ni. e Co nas rochas de Itapirapuã, evidenciado na Fig. 29, é concordante com as conclusões gerais alcançadas por Wager e Mitchell (1951, p. 189), e mais tarde confirmada por outros autores, de que a relação Ni/Co decresce de 


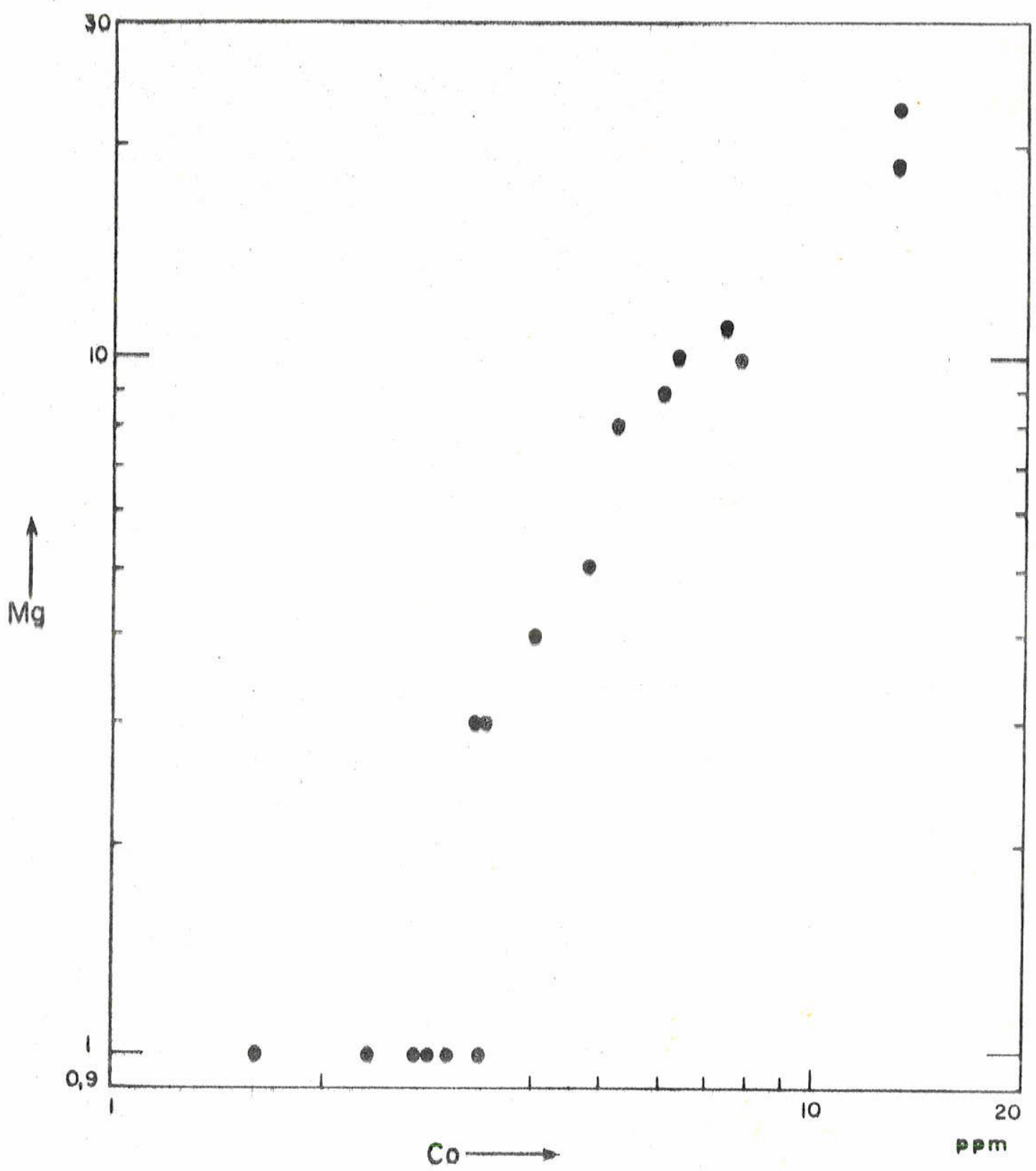

Fig. 28-Relacao entro $M g$ e Conas rochas de ltaplrapuă. 


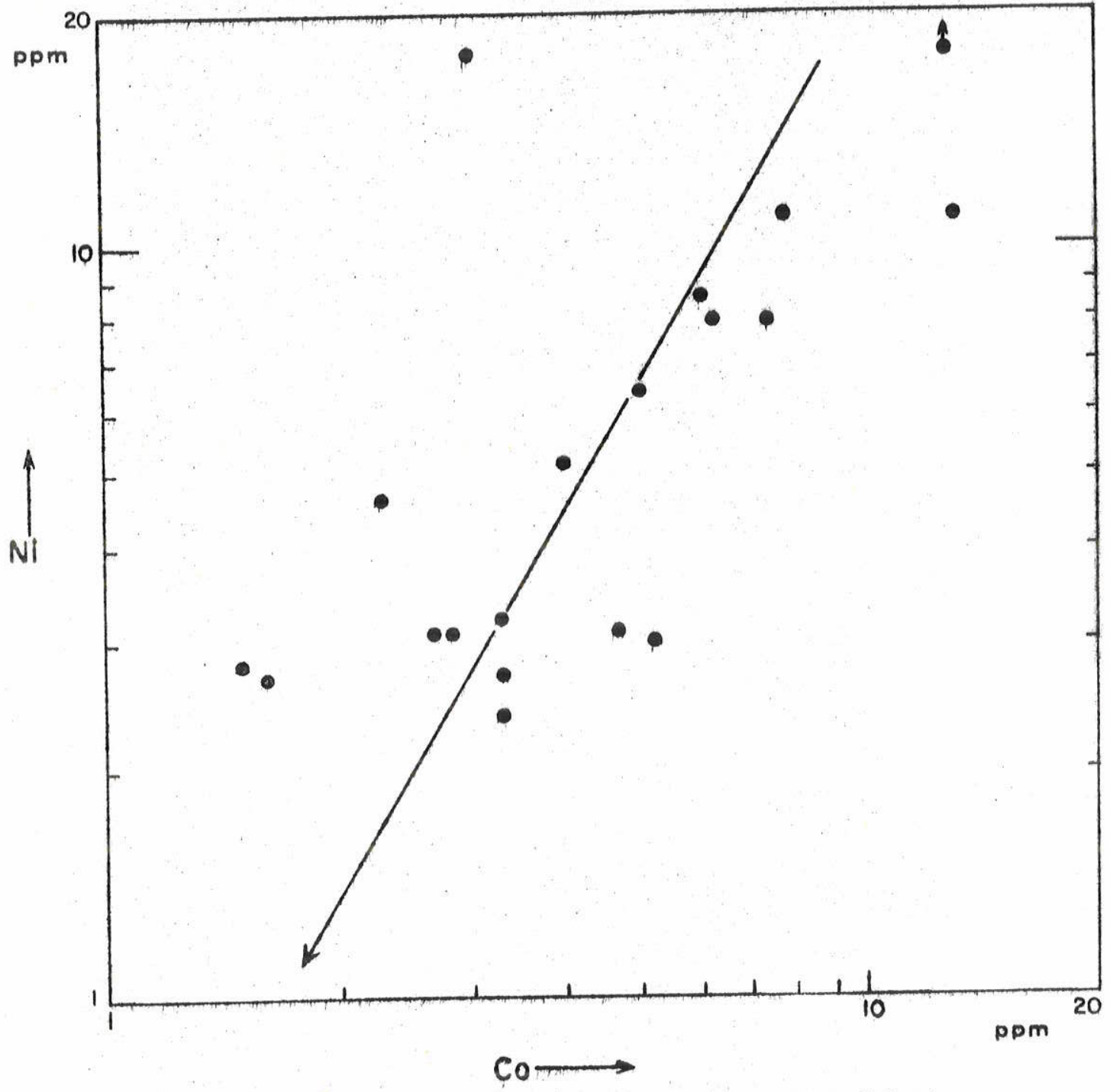

Fig. 29-Relaçöo entre Ni e Co nas rochos de Itapirapud. A seto indica o compartomento da relaçäo $\mathrm{Ni} / \mathrm{CO}$ durante o fracionamento magmático segundo Toylor $(1966, \rho, 172)$. 
forma progressiva durante os estádios da diferenciação magmática. Mais recentemente, Taylor (1966, p. 172) teve a oportunidade de en fatizar o comportamento dessa relação, valendo-se, então, de um grá fico no qual a curva representando Ni/Co tem um caráter decrescente e linear, passando de rochas ultrabásicas a graníticas.

Nas rochas de Itapirapuã, $\mathrm{Ni}^{2+}$ parece mostrar maior afinidade química com $\mathrm{Fe}^{2+}$, enquanto que o $\mathrm{Co}^{2+}$ parece asso ciar-se mais Intimamente a $\mathrm{Mg}^{2+}$. Esta interpretação é sugerida pe-. la concentração dêsses elementos nos minerais do grupo dos piroxê nios e granadas. Contudo, não deve ser excluída, face às considera ções formuladas atrás, a possibilidade de substituição, em menor es calla, de $\mathrm{Mg}^{2+}$ por $\mathrm{Ni}^{2+}$ e de $\mathrm{Fe}^{2+}$ por $\mathrm{Co}^{2+}$... Além dos piroxênios e granadas, níquel e cobalto podem também concentrar-se em minerais opacos, como tem sido comprovado em outras províncias alcalinas.

Os valores médios em Ni e Co para as rochas ana Lisadas de Itapirapuã ( 8,3 e 4,8 ppm), dados na Fig. 19, são inferiores aos encontrados para as rochas de Magnet Cove (14, 3 e 14, 5 ppm) e alcalinas mundiais, segundo o autor dêste trabalho (17 e 7 ppm) e superiores aos das alcalinas brasileiras $(2,6$ e $2,5 \mathrm{ppm})$ e mundiais de Turekian e Wedepohl (4 e 1 ppm).

Os teores médios em Ni e Co dos carbonatitos de Itapirapuã, 1,5 e 2,2 ppm são inferiores aos valores obtidos para os demais grupos litológicos do distrito (Tabela XXVI) e também menores que os valores encontrados para as rochas de Kaiserstuhl ( 5 e $14 \mathrm{ppm})$ e composição "média" (17,5 e 21,5 ppm) e "típica" (32,4 e $18,8 \mathrm{ppm}$ ) de Gold (Tabela XXII). Níquel e cobalto concentram se nas rochas carbonatíticas dos minerais opacos, quando então pare cem ocupar a posição do $\mathrm{Fe}^{2+}$.

Escåndio

Nas rochas de Itapirapuã, Sc está concentrado nos minerais do grupo das granadas e piroxênios e, subordinadamen te, na biotita e opacos. A presença dêsse elemento ocupando as posi. ções Mg-Fe de minerais ferromagnesianos é amplamente reconheci.. da na. Literatura em razão dos trabalhos de Oftedal (1943), Wager e Mitchell. (1951) e Borisenko (1959) e resulta de sua gxande afinidade 
química com magnésio e ferro bivalente. $\mathrm{Sc}^{3+}$ tem raio iônico $\left(\mathrm{Sc}^{3+}=\right.$ $=0,81)$ superior ao do $\mathrm{Mg}^{2+}$ e $\mathrm{Fe}^{2+}\left(\mathrm{Mg}^{2+}=0,66 \mathrm{e} \mathrm{Fe}^{2+}=0,74\right)$, en tretanto, sua eletronegatividade $\left(\mathrm{Sc}^{3+}=1,3\right)$ é um pouco maior que a do $\mathrm{Mg}^{2+}\left(\mathrm{Mg}^{2+}=1,2\right)$ e bem inferior a do $\mathrm{Fe}^{2+}\left(\mathrm{Fe}^{2+}=1,7\right)$. Este último fator é indicativo, segundo Ringwood (1955a, p. 199), da maior tendência de $\mathrm{Sc}^{3+}$ associar-se a $\mathrm{Fe}^{2+}$ antes que a $\mathrm{Mg}^{2+}$. Nos mine rais de Itapirapuã, $S_{c}{ }^{3+}$ parece estar presente ocupando a posição do $\mathrm{Fe}^{2+}$ (ver Tabelas IV e VIII), contudo, não deve ser excluída a possi bilidade, face às conclusões alcançadas por Nockolds e Mitchel(1948), daquele elemento estar também substituindo a $\mathrm{Ti}^{4+}$ nas granadas, e mesmo, na titanita. A relação Sc x 1000/Mg, dada na Fig. 25, tem um comportamento mais ou menos horizontal ao longo da série, para crescer de forma brusca no extremo félsico da curva. Para a rela ção Sc x 1000/Fe total não foi possível estabelecer-se qualquer com portamento face à dispersão mostrada pelos pontos projetados.

O teor médio em $\mathrm{Sc}$ das rochas alcalinas analisa das de Itapirapuã (3,8 ppm), apresentado na Fig. 19, mostra-se inferíor, a exceção do referente às alcalinas mundiais de Turekian e Wedepohl. (3 ppm), aos valores obtidos para as rochas de Magnet Cove $(8,6 \mathrm{ppm})$, alcalinas brasileiras $(8,4 \mathrm{ppm})$ e alcalinas mundiais, conforme o autor dêste trabalho (9,5 ppm).

Nos carbonatitos, Sc sòmente foi detectado na amostra C-2 e o teor obtido é de 10 ppm. O conteúdo médio relativo às quatro amostras analisadas (2,5 ppm), mostra-se inferior aos valores fornecidos por Gold para a sua composição "média" e "típica" , em ordem 11 e 10 ppm (Tabelas XXII). Escândio deve concentrar-se nos carbonatitos nos opacos, substituindo $\mathrm{Fe}^{2+}$ na estrutura dêsses minerais.

Itrio

Nas rochas de Itapirapuã, Y concentra-se nos mi nerais cálcícos, em especial nas granadas e piroxênios e, subordinadamente, na titanita e apatita. A afinidade química existente entre $\mathrm{Y}^{3+}$ e $\mathrm{Ca}^{2+}$ decorre da semelhança de raio iônico $\left(\mathrm{Y}^{3+}=0,92\right.$ e Ca $^{2+}=$ $=0,99)$. Tal fato permite ao Y ocupar a posição do cálcio na estrutura. dos minerais. A relação Y x 1000/Ca é demonstrada na Fig. 24. Nela 
observa-se que a curva obtida mantém-se horizontal em quase todo o seu traçado, para na altura do índice félsico 85, a exemplo do sucedi do com a quase totalidade das curvas que relacionam magnésio, cres cer de forma abrupta até o final. Este comportamento da referida re lação com Y enriquecendo-se relativamente a $\mathrm{Ca}$ ao longo da série, é consequência do conteúdo mais baixo em cálcio das rochas de maior ín dice félsico da série. O comportamento do ítrio nas rochas examinadas assemelha-se, em traços gerais, ao do vanádio, tendo como caracte rística marcante um maior enriquecimento nas rochas portadoras de melanita.

O teor médio em $\mathrm{Y}$ das rochas alcalinas analisadas de Itapirapuã, $70 \mathrm{ppm}$, é inferior ao valor fornecido por Guimarães e Dutra (1962) para as alcalinas do Brasil, 84 pp, (Fig. 19) e superior aos encontrados para as rochas de Magnet Cove, $30 \mathrm{ppm}$, e alcalinas mundiais de Turekian e Wedepohl, 20 ppm, e do autor desta obra, 58 ppm.

O conteúdo em Y dos carbonatitos de Itapirapuã, al to em relação ao dos nefelina sienitos e tinguaítos, dando como valor médio 49 ppm (Tabela XXI), parece refletir um comportamento anôma lo do elemento, pois ítrio deveria concentrar-se preferencialmente nos minerais cálcicos de cristalização injicial. Wickman (1943) sugeriu que dificuldades no equilíbrio de cargas forçaria $Y$, assim como as terras raras, a se enriquecerem nos magmas residuais. Ringwood (1955a, p. 200), contudo, procura explicar êsse comportamento a partir das relações de eletronegatividade entre êsses elementos. Segundo êsse Autor, a diferença no valor da eletronegatividade $\left(\mathrm{Y}^{3+}=1,2\right.$ e $\left.\mathrm{Ca}^{2+}=1,0\right)$, se bem que não muito grande, é suficiente para contrabalançar a influência da maior carga e, conseqtentemente, determinar o comportamento do elemento. Nas rochas carbonáticas $\mathrm{Y}^{3+}$ ocupa a posição do $\mathrm{Ca}^{2+}$ na estrutura da calcita e apatita.

O conteúdo médio em $Y$ dos carbonatitos analisa dos de Itapirapuã (49 ppm) é similar aos fornecidos para as rochas de Magnet Cove e Kaiserstuhl, 40 e 45 ppm (Tabela XXII) e bem inferior aos dados por Gold para composição "média" e "típica", 137,8 e $113,7 \mathrm{ppm}$ respectivamente. 
Cálcio e Estrôncio

A curva do Ca (Fig. 23) descreve regularmente atra vés da série à medida que aumenta o índice félsico. Já a curva do Sr, integrando a mesma figura, difere em certos aspectos da anterior, pois, ao lado de um declive mais suave, mostra também maior disper são dos pontos projetados. $\mathrm{Sr}^{2+}$, dado o tamanho do seu raio iônico $\left(\mathrm{Sr}^{2+}=1,12\right)$, pode ser admitido na estrutura de minerais cálcicos $\left(\mathrm{Ca}^{2+}=0,99\right)$, ou então, capturado por minerais potás sicos $\left(\mathrm{K}^{+}-1,33\right)$. Do ponto de vista teórico (Taylor, 1966, p. 154), S $\mathrm{r}^{2+}$ deve mostrar um aumento com relação a $\mathrm{Ca}^{2+}$ no curso do fracionamento magmático. Este fenômeno, já comprovado por alguns pesquisadores (Nockolds e Mitchell, 1948; Wagex e Mitche11, 1951), foi igualmente observado nas rochas de Itapirrapuã (Fig.24), com a relação Sr x 100/Ca passando de um valor mínimo de 0,79 , no melanita malignito, a um máximo de 6,0 , no tinguaíto da amostra 19. A ausência de interdependência di reta entre $\mathrm{Sr}^{2+}$ e $\mathrm{Ca}^{2+}$ foi também notada nas rochas investigadas, a exemplo do sucedido nas intrusivas alcalinas que compõem o maciço de Lovozero (Península do Kola, Rússia). Este último fato foi interpretado por Gerasimovskii e Lebedev (1958, p.703) como resultante, provàvelmente, da substituição isomórfica de $\mathrm{Ca}^{2+}$ e $\mathrm{K}^{+}$por $\mathrm{Sr}^{2+}$. Parece vir a favor dessa explicação, o fato de que nos piroxênios de Itapirapuã, minerais pràticamente desprovidos de potássio, a coe rência geoquímica entre $\mathrm{Sr}^{2+}$ e $\mathrm{Ca}^{2+}$ está presente. A relação $\mathrm{Sr} \mathrm{x}$ $x$ 100/Ca + K (Fig. 24) exibe um comportamento horizontal nas partes inicial e intermediária da curva, crescendo depoìs ligeira. mente no final. Nas rochas de Itapirapuã, $\mathrm{Sr}^{2+}$ deve concentrar-se principalmente nos minerais cálcicos (granadas, piroxênios, cancrinita, titanita, apatita, etc.), caso em que ocupa a posição do $\mathrm{Ca}^{2+}$ nas suas estruturas e, subordinadamente, nos minerais félsicos portadores de potássio e, em quantidade muito pequena, de cálcio em sua com posição (feldspatos e feldspatóides), quando então pode estar substi tuindo a ambos, $\mathrm{K}^{+}$e $\mathrm{Ca}^{2+}$.

O campo de variação do Sr para as rochas alcalinas analisadas de Itapirapuä, excluindo-se os carbonatitos, cobre um inter valo relativamente pequeno sendo os valores limites da ordem de 370 e $1000 \mathrm{ppm}$ (Fig. 19). O teor médio obtido, $660 \mathrm{ppm}$, é um pouco inferior aos valores encontrados para as alcalinas brasileiras, 959 ppm, e alca 
linas mundiais conforme o autor dêste trabalho, $827 \mathrm{ppm}$, e situa-se muito aquém da média das rochas de Magnet Cove, 2595 ppm. O va lor apresentado por Turekian e Wedepohl, 200 ppm, é bem inferior às demais médias.

A concentração de $\mathrm{Sr}$, assim como de $\mathrm{Ba}$, em car bonatitos já é de há muito referida na literatura (von Eckermann , 1952: Higazy, 1954, etc。) e constitui, segundo Pecora (1956, pp. 1544-1545), uma das feições químicas caracterîsticas dêsse grupo de rochas. O teor médio em Sr para os carbonatitos analisados de Itapi rapuã, $1410 \mathrm{ppm}$ (Tabela XXI) é bem superior ao das demais rochas que compôem o maciço, porém, é consideràvelmente inferior aos va Jores encontrados para os carbonatitos de Magnet Cove (5000 ppm), Kaiserstuhl (6500 ppm) e carbonatitos de composição química "mé dia." (6800 ppm) e "típica" (7500 ppm) de Gold (Tabela XXII). Nos car bonatitos, Sr associa. se principalmente aos minerais cálcicos (calcí ta e apatita), contudo não deve ser excluída a possibilidade dêsse ele mento estar tambe̊m concentrado no feldspato alcalino.

Potássio e Bário

A curva do K (Fig. 23) cresce no decurso da sé rie à medida que aumenta o índice félsico. Já o comportamento do Ba, constando também da figura anterior, é marcado por um crescí mento regular até a altura do índice 75 , quando então passa a decres cer ràpidamente até o extremo félsico da série. A relação Ba $\times 100 / K(F i g 。 24)$ tem um traçado similar à curva do Ba, diferin.. do apenas no declive do extremo félsico da curva que se apresenta mais acentuado que na anterior. A relação Ba/K passa de um valor ì nicial de 2,0 , no biotita melteigüto, a um valor máximo de 7,6, no melanita nefelina sienito da amostra 8, terminando por alcançar um mínimo de 0,17 , no tinguaíto da amos tra 18. A coerência química existente entre $\mathrm{K}^{+}$e $\mathrm{Ba}^{2+}$ decorre da grande similaridade de seus raios iônicos $\left(\mathrm{K}^{+}=1,33\right.$ e $\left.\mathrm{Ba}^{2+}=1,34\right)$. Como corolário do princŕ. pio clássico da captura, $\mathrm{Ba}^{2+}$ tende a entrar na estrutura dos mine rais potássicos de cristalização inicial, razão pela qual o seu teor nas rochas de tiapirapuã aumenta nas fases inicial e intermediárìa da série. Contudo, segundo Goldschmidt (1954, p. 251.), após a utiliza. 
ção da maior parte do bário disponível, o líquido magmático remanes cente, mesmo se ainda contendo potássio em sua composição, pode dar origem a membros pobres em bário na fase final de cristaliza. ção da série. Nas rochas de Itapirapuã, Ba ${ }^{2+}$ associa-se ao feldspato alcalino e nefelina, e provàvelmente, à biotita nas rochas portadoras dêsse mineral.

O teor médio em Ba das rochas analisadas de Ita.. pirapuã, $2256 \mathrm{ppm}$ (Fig。19), é superior às médias conseguidas para as rochas de Magnet Cove (2059 ppm), alcalinas brasileiras (874 ppm), alcalinas mundiais de Turekian e Wedepohl (1600 ppm) e alcali nas mundiais segundo o autor da presente obra (892 ppm)。 Os dados encontrados permitem deduzir que a relação $\mathrm{Ba} / \mathrm{Sr}$ é maior nas ro chas silicálicas de Itapirapuã que nas rochas de Magnet Cove. Este fa to é interpretado como decorrente de diferenças mineralógicas causa das pela maior abundância de feldspatos em relação a máficos cálci cos nas rochas da primeira província.

$\mathrm{Ba}$, a exemplo do Sr, parece estar igualmente con centrado nos carbonatitos de Itapirapuã. Contudo, o seu teor médio para essas rochas é da ordem de 1995 ppm (Tabela XXI) e, contrário ao sucedido com o Sr, é inferior ao apresentado pelas demais varie dades petrográficas que compõem o maciço. No quadro comparativo dado na. Tabela XXII, verifica-se que a média de Sr nos carbonatitos de Itapirapuã é bem menor que as fornecidas para as rochas de Kai serstuhl (5000 ppm) e a composição química "média" (3600 ppm) e "tí pica" (4000 ppm) fornecidas por Gold. Nos carbonatitos de Itapirapuã, $\mathrm{Ba}^{2+}$ deve concentrar-se nos feldspatos, ocupando a posição de $\mathrm{K}^{+} \mathrm{na}$ estrutura dêsses minerais.

Sódio

A curva do $\mathrm{Na}$ (Fig。23) cresce regular e moderadamente à medida que aumenta o índice félsico.

\section{Zircồnio}

$\mathrm{Zr}^{4+}$, em razão da alta carga e raio iônico relativamente grande $\left(\mathrm{Zr}^{4+}=0,79\right)$ não entra com facilidade nos retículos 
cristalino, podendo vir a formar nas soluçöes residuais uma fasem netalógica solada, o zircão. Contudo, segundo Taylor (1966, p. 164), êle tambèm porre substituindo, em maior ou menor grau, ao $\mathrm{Ti}^{4+}{ }^{4}$ estrutura de minerais silucáticos, e além disso acompanha o $\mathrm{Ti}^{4+}$ quan do êsse elemerto ocupa a posição do $\mathrm{Fe}^{3+}$. Wager e Mitchell $(1951, \mathrm{p}$. 192) são de opiniăo que $\mathrm{Zr}^{4+}$ ap arentemente substutu $\mathrm{Ca}^{2+}$ nas es truturas de piroxeño e apatita. O conteúdo em Zr das rochas de Itapi rapuâ. nâo mostra quảsquer variaçöes indicativas de um comporta mento regulax dêsse elemento ao longo da série investigada. Este fato partece contradizer as conclusões alcançadas por Goldschmidt (1954, p.424) mats tarde confurmada por Chao e Fleisher (1960,p.126) de que $Z x$ se concentra no decurso da cristalização fracionada. Contudo, uma varĭaçăo regular no teor em Zr é exibida pelos membros que compöm a série dos piroxênios dessas rochas, levando a um enrique chmento desse elemento nos têrmos mais egirinicos da série (Fig. 14). E provável que $\mathrm{Zr}^{4+}$ ocupe a posição do $\mathrm{Ca}^{2+}$ na estrutura dêsses minerals, como sugerido por Wager e Mitchell (1951) e que se acumule relativamente a cälcto no sentido da cristalização da série (sodamaugita $\longrightarrow$ egirina augita $\longrightarrow$ egirina). Nas rochas de Itapirapua, $\mathrm{Zr}^{4+}$ se concuntra principalmente nos minerais do grupo das gxanadas e piro xênios, contudo, deve também estar presente, em menor quantidade, na stanita, apatita, etc. E possivel, dado o alto conteúdo dèsse element to nas granadas (ver Tabela VIII), que $\mathrm{Z}^{4} \mathrm{x}^{4}$ ocorra nesses minerais substituindo quer a $\mathrm{T}^{4+}$, quer a $\mathrm{Ca}^{2+}$. Não for am reconhecidos cris tais de zario nas rochas investigadas, a despeito do teor rellativamen te elevado em $Z x$ de algumas delas.

O teor médjo em Zr das rochas analisadas de Itapi rapuã, 436 ppm (Fug. 19), é superior ao das rochas de Magnet Cove , 206 ppm, e inferiox aos valores fornecidos paxa as alcalinas mundiais de Turekian e Wedepohl, 500 ppm, e alcalinas mundiais segundo o au ror deste trabalho, $786 \mathrm{ppm}$, e situa-se bem abajxo da média exibida pelas rochas alcalinas brasilearas, 1520 ppm.

O conteúdo em Zx nos carbonatitos analisados é muito baixo e consider àvelmente menor que os das demais variedam des petrográficas do maciço. O valor médio obtido, da oxdem de 22 ppm (Tabela XXII), sömente E malor que o valor apresentado pelo car bnatuto de Magnet Cove, 10 ppm. Mostramse um pouco inferior à mé 
dia das rochas de Kaíserstuhl e muito aquém dos valores dados por Gold para a sua composição "média", 925 ppm, e "ípica", 461 ppm. Do ponto de vista da concentração mineral, $\mathrm{Zr}^{4 t}$ parece estar asso ciado nas rochas carbonáticas à magnetita e calcita, quando então substitui a $\mathrm{Ti}^{4 t}$ e $\mathrm{Ca}^{2+}$ na estrutura desses minerais.

Níóbio

A coerência geoquímica entre $\mathrm{Nb}^{5+} \mathrm{e}^{4+} \mathrm{i}^{4+}$ decor rência da similaridade de raio iônico $\left(\mathrm{Nb}^{5+}=0,69 \mathrm{e} \mathrm{Ti}^{4+}=0,68\right)$ é fato amplamente aceito na liter atura (Goldschmidt, 1954; Gerasinovs kii, 1956), e nióbio tem sido interpretado como substituindo o segundo elemento na estrutura de minerais portadores de titânio. Taylor (1966, p. 166) admite também a possibilidade de $\mathrm{Nb}^{5+}$ substituir a $\mathrm{Sn}^{4+}, \mathrm{Zr}^{4+}$ e $\mathrm{Mo}^{6+}$, visto que os raios iônicos dêsses elementos $\left(\mathrm{Sn}^{4 t}=0,71, \mathrm{Zr}^{4 t}=0,79\right.$ e $\left.\mathrm{Mo}^{6+}=0,70\right)$ são comparáveis. Em razão do valor elevado do seu potencial iônico $\left(\mathrm{Nb}^{5+}=7,25\right)$, Nb pode estar presente nas frações magmáticas formando complexos do tipo $\left(\mathrm{NbO}_{4}\right)^{3-}$. Esses complexos, em consequência de seu maior tamanho, quando cornparado com o $\left(\mathrm{SiO}_{4}\right)^{4-}$, não são prontamente aceitos na es trutura dos silicatos e tendem a se acumular no líquidó tesidual..... (Ringwood, 1955b, p. 247). Em Itapirapuã, não se registraram variăções significativas no conteúdo de $\mathrm{Nb}$ das rochas que integram a sé rie investigada. Contudo, parece que os piroxénios da província guar dam uma relação direta entre o conteủdo de $\mathrm{Nb}$ e a sua natureza egirínica. Essa relação (Fig. 14), se bem que não muito convincente, pa. rece indicar que a concentração de $\mathrm{Nb}$ aumenta diretamente com a porcentagem da molécula de egirina désses minexais. Nas rochas de Itapirapuã, Nb se concentra preferencialmente nas melanitas e, su. bordinadamente nos membros da série dos piroxènios e titanita.

A média em $\mathrm{Nb}$ das alcalinas analisadas de Itapira puã, $1.82 \mathrm{ppm}$ (Fig. 19), está acima das relativas às rochas de Magnet Cove, 109 ppm, e alcalinas mundiais de Turekian e Wedepoh1, 35 ppm, e bem abajxo do valox médio encontrado para as rochas brasi. leiras, 178 ppm. Mostra-se, todavia, pràticamente idêntica à média por nós obtida para as rochas alcalinas mundials, 180 ppm.

O conteúdo em $\mathrm{Nb}$ dos carbonatitos analis sados de 
Ttapirapuã (Tabela XXI), com um teor médio de 152 ppm, mostra se inferior aos valores médios conseguidos para os vários grupos litoló gícos da província, a exceção dos nefelina sienitos (ver Tabela XXVI)。O teor em Nb dos carbonatitos analisados, especialmente da amostra $\underline{\mathrm{C}-1 \mathrm{~A}}$, parece ser muito elevado face à composiçäo mineralógica dessas rochas. Contudo, é bem possível que, ao lado da mag netita e melanita, existam nessas rochas outros minerais, na condição de acessórios, portadores de nióbio. Pecora (1956, p.1545) chama a atenção para a freqư̂encia da concentração de minerais niobífe ros (pirocloro, columbita, perovskita e outros) em carbonatitos, le vando mesmo à formação de depósitos económicamente aproveitáveis, como é o caso de Araxá (Brasil), Fen (Noruega), Kaiserstuhl (Alema nha Ocidental), etc., e inúmeras ocorrências situadas no continente africano. Deans (1966, p. 396) menciona a existência de 25 ocorrências de carbonatitos ricos em nióbio espalhados entre Damaraland no sudoeste da Årica, parte oriental do Transvaal e norte de Uganda. No quadro comparativo da Tabela XXII, verifica-se que a média em $\mathrm{Nb}$ dos carbonatitos de Itapirapuã, $153 \mathrm{ppm}$, é inferior àquela das rochas da província de Kaiserstuhl, 620 ppm. Lamentàvelmente, porém, Gold não fornece dados para o $\mathrm{Nb}$ na sua composição "média" e "tipi$\mathrm{ca}^{1 !}$ 。

\section{Lantânio}

A associação das terras raras com cálcio e, por vèzes com estróncio, é muito característíca de minerais de rochas alcalinas. Esta as sociação pode ser explicada (cf. Gerasimovskin, 1956, p.501) pela substituição diadóquica de $\mathrm{Ca}^{2+} \mathrm{e} \mathrm{Sr}^{2+}$ por terras raras, dada a semelhança de seus raios iônicos $\left(\mathrm{Ca}^{2+}=0,99 ; \mathrm{Sr}^{2+}=1,12\right.$; $\left.\mathrm{Y}:=0,92 \mathrm{e} \mathrm{Ce}^{3+}=1,07\right)$. Semenov (1958), estudando a relação entre a composição das terras raras e composição e estrutura dos minerais de rochas, chegou à conclusão que os minerais portadores de Sr, Ba e K são usualmente selectivos para o "grupo do cério" (lantânio a eu. rópio), os minerais ricos em $\mathrm{Zr}$, Sc e Fe são selectivos para o "grupo do ítrio" (gadolínio a lutécio, incluindo itrio), enquarto que os mine raìs de $\mathrm{Ca}$, face ao tamanho intermediário de seu raio ĩônico, têm com portamento complexo. La ${ }^{3+}$, em razão de sua maior eletronegativida- 
de $\left(\mathrm{La}^{3+}=1,14 \mathrm{e} \mathrm{Ca}^{2+}=1,0\right)$, concentra-se relativamente a $\mathrm{Ca}^{2+}$ no decurso da cristalização fracionada (Ringwood, 1955a, p。200), che gando mesmo a se enriquecer nas soluções residuais. O comporta mento do lantânio em Itapirapuã é marcado por uma alta concentra ção dêsse elemento nas rochas iniciais da série, biotita melteigito e melanita malignito, decrescendo depois essa concentração no grupo dos melanita-nefelina sienitos e nefelina sjenitos, para depois nova mente crescer nos tinguaítos e carbonatitos (ver Tabelas XXI e XXVI). Nas rochas analisadas, $\mathrm{La}^{3+}$ parece estar associado à titanita e apa. titea, ocupando a posição do $\mathrm{Ca}^{2+}$ na estrutura dêsses minerais。 $\mathrm{O}$ conteúdo elevado dếsse elemento nas amostras 1 e 2 (biotita melteigí to e melanita malignito) é reflexo da abundância dos minerais cititados (ver análises modais da Tabela Ia). O La foi também detectado e, pro vàvelmente substituindo o $\mathrm{Ca}$, em duas amostras dos piroxênios estudadas (Am. 13a e 14a), sendo os teores obtidos (Tabela IV), em or dem, 196 e 100 ppm.

O teor médio em La das rochas analisadas de Itapi rapuã, da ordem de 160 ppm (Fig. 19), é idêntico ao valor encontra do para a província de Magnet Cove, mostrando-se contudo, bem inferior às médias das alcalinas brasileiras, 327 ppm, e alcalinas mun diais segundo o autor dêste trabalho, 288 ppm. A média aritmética fornecida por Turekian e Wedepohl, 70 ppm, está muito abaixo dos de mais valores.

A concentração de lantânio em carbonatitos tem sido observada por vários pesquisadores (Higazy, 1954; Olson et al. „1954; van Wambeke, 1964, etc。) e constitui, segundo Pecora (1956), uma ca racterística química comum dêsse grupo de rochas. A afinidade quími ca existente entre o $\mathrm{Ca}^{2+}$ e $\mathrm{La}^{3+}$ é, mais uma vez, o fator responsá vel pela presença dêsse último elemento na estrutura dos miner ais cál cicos, apatita e, em menor escala, na calcita.

A média em La dos carbonatitos de Itapirapuã, 385 ppm (Tabela XXII), está um pouco acima daquela relativa às rochas de Magnet Cove, 300 ppm, e bem abaixo da referente aos carbonatitos de Kaiserstuhl, 800 ppm. Gold não fornece dados para êsse elemento em sua composição "média" e "típica" de carbonatitos. 
Cobre

Este elemento, apresentado nas Tabelas XXVa e XXVb sob a forma de $\mathrm{Cu}^{2+}$, pode também estar presente nas rochasig neas como $\mathrm{Cu}^{+}$. Em geral $\mathrm{Cu}^{2+}$ liga-se a $\mathrm{Fe}^{2+}$, enquanto que $\mathrm{Cu}^{+}$ mostra maior afinidade para com $\mathrm{Na}^{+}$. Estas associações são explica das pela similaridade dos raios iônicos dêsses elementos $\left(\mathrm{Cu}^{2+}=0, \overline{72}\right.$ e $\left.\mathrm{Fe}^{2+}=0,74 ; \mathrm{Cu}^{+}=0,96 \mathrm{e} \mathrm{Na}^{+}=0,97\right)$. A ligação Cu-O tem carå tex mais covalente que as ligações $\mathrm{Na}-\mathrm{O}$ e $\mathrm{Fe}-\mathrm{O}$ visto que os valores da. eletronegatividade de cobre são maiores que os relativos ao sódio e ferro $\left(\mathrm{Cu}^{2+}=2,0 \mathrm{e} \mathrm{Fe}^{2+}=1,65 ; \mathrm{Cu}^{+}=1,8 \mathrm{e} \mathrm{Na}{ }^{+}=0,9\right)$, e tal fato, segundo Ringwood (1955a, p. 196), leva à acumulação dêsse elemento (Cu) na.s soluções magmátícas residuais. Nas rochas de Itapir apuã (ver Tabella XXVI), Cu se comporta de forma irregular dentro da série in vestigada, passando de um valor inicial de 150 ppm, na biotita melteigito, a $160 \mathrm{ppm}$, no melanita malignito, para depois decrescer nos me lanita nefelina sienitos (10l ppm) e nefelina sienitos (87 ppm) e terminar aumentando nas rochas tinguaíticas (95 ppm). A associação de Cu ${ }^{2 t}$ com $\mathrm{Fe}^{2+}$ é sugerida pela presença do primeiro elemento na composi. ção das granadas (Tabela VIUI), enquanto que $\mathrm{Cu}\left(\mathrm{Cu}^{2+} \mathrm{e} / \mathrm{ou} \mathrm{Cu}{ }^{+}\right.$) pode ocorrer associado a $\mathrm{Na}^{+} \mathrm{e} / \mathrm{ou} \mathrm{Fe}^{2+}$ nos piroxênios, visto que êsses minerais são sódicos e ferrosos em sua composição. Não deve ser ex. cluída a possibilidade de $\mathrm{Cu}^{+}{ }^{\dagger}$ concentrar-se também nos minerais fél sicos (feldspatos e feldspatóides) das rochas da província, ocupando a posição do $\mathrm{Na}^{+}$.

O teor médio em $\mathrm{Cu}$ das rochas alcalinas analisadas de Itapirapuã é de 96 ppm e, como pode ser visto h na Fig. 19, situa - se acima dos valores fornecidos para as rochas de Magnet Cove ( 46 ppm), alcalinas brasileiras (43 ppm), alcalinas mundiais do autor desta obra (70 ppm) e alcalinas mundiais de Turekian e Wedepohl. (5 ppm).

A concentração do $\mathrm{Cu}$ nas rochas carbonáticas é mui to elevada e o teor médio obtido, $112 \mathrm{ppm}$ (Tabela XXI), somente é infe rior aos valores fornecidos para o biotita melteigito e melanita maligni to (Tabela XXVI). O cobre, presente na forma de $\mathrm{Cu}^{2+}$, parece estar as sociado nos carbonatitos aos minerais opacos, magnetita e pirrotita, quando então substitui a $\mathrm{Fe}^{2+}$ na estrutura dêsses minerais.

$\mathrm{O}$ conteúdo médio em $\mathrm{Cu}$ dos carbonatitos de Itapíra. 
puã, a exemplo do sucedido com as rochas silicáticas, é bem supe rior às demais médias obtidas. Os valores fornecidos para essas rochas são os seguintes: Magnet Cove (10 ppm), Kaiserstuhl (17 ppm) e composição químíca "média" (30,3 ppm) e "típica" (88 ppm) de Gold (Tabela XXII).

Ber ว̊lio

$\mathrm{Be}^{2+}$, em razão do pequeno tamanho, está presen te nos magmas parcialmente na forma de $\left(\mathrm{BeO}_{4}\right)^{6-}$. Este grupo, de car ga elevada, deveria ser prontamente aceito na estrutura dos silicatos (cf. Ringwood, 1955b, p. 247). Contudo, tal fato não se verifica. visto que Be tende a se concentrar nas soluções magmáticas residuais (Sandell. 1952, p. 211). A explicação para êsse fato, dada por Ringwood (1955b, p. 247), é que em virtude da baixa carga do $\mathrm{Be}$, a Jigação $\mathrm{Be}-\mathrm{O}$ é instável às temperaturas magmáticas. $\mathrm{Assim}, \mathrm{Be}^{2+}$ po derá ocorrer parcialmente na condição de íon livre. Se consideradas as similaridades existentes entre $\mathrm{Be}^{2+}$ e $\mathrm{Si}^{4+}$, mesmo número de cooxdenação com respeito ao oxigênio, semelhança de raio iônico ( $\mathrm{Be}^{2+}=$ $\left.=0,35 \mathrm{e} \mathrm{Si}^{4+}=0,42\right)$ e de eletronegatividade $\left(\mathrm{Be}^{2+}=1,5 \mathrm{e} \mathrm{Si}^{4+}=1,8\right)$, não é difícil explicar a substituição na estrutura dos silicatos do te traedro $\left(\mathrm{SiO}_{4}\right)^{4-}$ pelo $\left(\mathrm{BeO}_{4}\right)^{6-}$. Todavia, o fator primordial que dificulta a captura de Be pelos silicatos é a diferença de cargas existen tes entre $\mathrm{Si}^{4 t}$ e $\mathrm{Be}^{2+}$, visto que no momento da substituição há ne cessidade da entrada de um elemento com carga elevada a fim de que - equilíbrio eletrostático seja mantido. A alta concentração de Be nos minerais das rochas que se consolidaram nos estádios finais decorre exatamente da presença de cátions de alta valência (Nb, Zro terras raras, etc。), ou então, da presença de ânions de baixa valência como $(\mathrm{OH})^{\infty}$ e $\mathrm{F}^{-}$. Estes fatôres favorecem a entrada de Be nos retículos crístalinos. As rochas de Itapirapuã não exibem qualquer evidência in

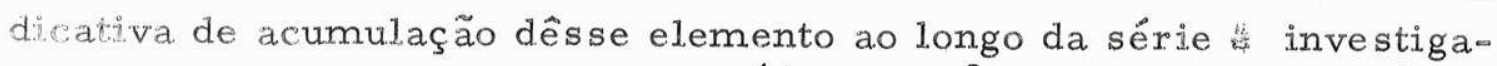
da. A substitiuição diadóquica de $\mathrm{Si}^{4+}$ por $\mathrm{Be}^{2+}$, ou mesmo de $\mathrm{Al}^{3+}$ por $\mathrm{Be}^{2+}$, pode ter ocorrido nos minerais dessas rochas ao longo de todo processo de diferenciação. Beus (1956, p. 518) admite a possibilidade de substituição diadóquica heterovalente entre $\mathrm{Si}^{4+}$ e $\mathrm{Be}^{2+}$ em presença de cátions de alta valência para os principais minerais das 
rochas ígneas (feldspatos, nefelina, piroxênios, anfibólios, etc。)。Erickson e Blade (1963, p. 65) verificaram a presença dêsse elemento na quase totalidade dos minerais existentes nas rochas da província de Magnet Cove. Observaram também que Be tende a se concentrar mais nos minerais secundários que nos primários.

A exceção da média fornecida por Turekian e Wedepohl para as alcalinas mundiais (1 ppm), os teores médios em Be das diferentes rochas que integram a Fig. 19 são pràticamente idên. ticos。 Os valores obtidos for am os seguintes: 7,2 ppm para as ro chas de Itapirapuã, 8, 4 ppm para as rochas de Magnet Cove, 7,2ppm para as alcalinas brasileiras e 7,3 ppm para as alcalinas mundiais se gundo os dados por nós coligidos.

Be não foi detectado nos carbonatitos de Itapirapuã e a Tabela XXII mostra que a concentração désse elemento nesse tipo de rochas é muito pequena. O valor mais elevado para as médias apre sentadas é de 5 ppm e corresponde ao da composição "típica" de Gold.

\section{Molibdênio}

Em geral assume-se que êsse elemento ocorre nas rochas ígneas na forma de $\mathrm{Mo}^{4+}$, entretanto, outras valências $\left(3^{t}, 5^{t}\right.$ e $\left.6^{t}\right)$ são igualmente esperadas. As análises dos minerais mais comuns das rochas ígneas demonstram que Mo pode ocorrer em proporções espectogråficamente significativas em feldspatos, piroxênios, anfibólios, biotita e especialmente em magnetita-ilmenita (Kuro da e Sande11, 1954, p. 47). Esste fato é explicado pela faculdade de $\mathrm{Mo}^{4+}$, dada a similaridade dos raios iônicos $\left(\mathrm{Mo}^{4+}=0,70 ; \mathrm{Al}^{3+}=\right.$ $\left.\therefore 0,51 ; \mathrm{Fe}^{3+}=0,64 \mathrm{e} \mathrm{Ti}^{4 t}=0,68\right)$, de substituir a $\mathrm{Al}^{3+}, \mathrm{Fe}^{3+}$ e $\mathrm{Ti}^{4+}$ nos retículos dos cristais. Segundo Taylor (1966, p. 167), Mo está pre sente no líqưido magmático, quer na forma de íns livres, quer for mando complexos do tipo $\left(\mathrm{MoO}_{4}\right)^{4-\text {. }}$. Estes complexos, em razão do maior tamanho quando comparados $\operatorname{com}\left(\mathrm{SiO}_{4}\right)^{4-}$, tendem a se acu mular nas soluções magmáticas residuais (cf. Ringwood, 1955b, p. 253)。Vinogradov et al. (1958, p. 497), estudando o comportamento dêsse elemento em rochas ultrabásicas, básicas, intermediárias e á cídas, concluiram que o conteúdo de Mo dessas rochas varia direta nente com o teor em $\mathrm{SiO}_{2}$, passando de um valor minimo de 0,23 ppm 
a um máximo de 1,6 ppm. O conteúdo em Mo das rochas de Itapira puã não apresenta variações marcantes, indo dos têrmos mais bási cos aos mais ácidos da série. Mo ${ }^{4+}$ pode estar concentrado nas rochas investigadas nos minerais félsicos (feldspatos e feldspatóides), substituindo ao $\mathrm{Al}^{3+}$ e/ou nos minerais máficos (piroxênios, grana das, magnetita, etc.), quando então estaria ocupando a posição de $\mathrm{Fe}^{3+}$ e $\mathrm{Ti}^{4+}$ na estrutura dêsses minerais.

O teor médio obtido para as alcalinas analisadas de Itapirapuã, 7, 7 ppm, apresentado na Fig. 19, é um pouco supe rior aos valores encontrados para as rochas de Magnet Cove, 3, 8 ppm, e alcalinas mundiais segundo o autor desta obra, 2, 5 ppm. A média aritmética fornecida por Turekian e Wedepohl, 0,6 ppm não está representada na figura referida.

Mo, a exemplo do sucedido com Be, não foi detec tado nos carbonatitos de Itapirapuã. Contudo, o quadro comparativo da Tabela XXII permite notar que êsse elemento pode estar presente nesse tipo de rochas em proporções significativas, haja visto os teores médios, 59 e 64 ppm, fornecidos por Gold, respectivamente, para a sua composição química "média" e "típica".

Chumbo

Chumbo está presente nas estruturas dos silicatos principalmente como $\mathrm{Pb}^{2+}$. Em razão de possuir raio iônico interme diário ao do $\mathrm{K}^{+}$e Ca ${ }^{2+}\left(\mathrm{Pb}^{2+}=1,20 ; \mathrm{K}^{+}=1,33 \mathrm{e} \mathrm{Ca}^{2+}=0,99\right)$, se ria esperado ocorrer em minerais potássicos (feldspatos alcalinos, feldspatóides, etc.) e cálcicos (plagioclásios, apatita, etc.). De acôr do com as regras de Goldschmidt, $\mathrm{Pb}$ deveria ocupar a posição do $\mathrm{K}$ nos minerais potássicos de cristalização inicial, contudo, segundo Taylor (1966, p. 185), a ligação $\mathrm{Pb}-\mathrm{O}$ é muito mais covalente que a $1 \mathrm{i}$ gação K-O, o que leva à acumulação do primeiro elemento $(\mathrm{Pb})$ nas soluções residuais. $\mathrm{Pb}^{2+}$, dada a sua maior carga e caráter mais co valente da ligação $\mathrm{Pb}-\mathrm{O}$ em relação a $\mathrm{Ca}-\mathrm{O}$, deve concentrar-se relativamente a $\mathrm{Ca}^{2+}$ durante a cristalização fracionada. A coerência geo química entre $\mathrm{Pb}$ e $\mathrm{K}$ nas rochas ígneas foi primeiramente defendida por Sandell e Goldich (1943). Todavia, nas rochas de Itapirapuã, essa coerência parece não existir e uma possível explicação para isso re - 
side no fato de que $\mathrm{Pb}$, além de substituir a $\mathrm{K}$ na estrutura dos felds patos alcalinos e nefelina, ocorre também ocupando a posição do Ca na estrutura dos minerais do grupo das granadas e piroxênios. Apre sença de $\mathrm{Pb}^{2+}$ substituindo diadòquicamente a $\mathrm{Ca}^{2+}$ na estrutura de piroxênios foi admitida por Zlobin e Gorshkova (1961, p. 120) eg seu estudo sobre o comportamento do chumbo e zinco nas rochas do maciço alcalino de Sandyk, Rússia.

O comportamento do $\mathrm{Pb}$ na série investigada. prin cipalmente se considerados os teores médios para os diferentes gru pos petrográficos da província (Tabela XXVI), tem como característi ca primordial o maior enriquecimento dêsse elemento nas rochas tin guaíticas, o que viria a favor da idéia defendida por Gerasimovskii. e Newmeyanova $(1960, p \circ 704)$ de que èsse elemento se enriquece no sen tido da cristalização fr acionada.

O teor médio em $\mathrm{Pb}$ das rochas alcalinas analisadas de Ttapirapuã, da ordem de $42 \mathrm{ppm}$, situa-se muito acima dos valores fornecidos para as alcalinas mundiais de Turek an e Wedepohl, 12 ppm, e rochas do maciço alcalino de Lovozero na Rússia., 14,6 ppm (Gerasimovskil e Nesmeyanova, 1960) e mostra-se um pouco inferior à média de 58 ppm estabelecida por Zlobin e Gorshkova (1961) para as rochas do distrito alcalino de Sandyk, Rússia.

Chumbo se concentra em pequena quantidade nos carbonatitos analisados de Itapirapuã, sendo o conteúdo médio obtido. 24 ppm (Tabela XXII), inferior ao dos demais grupos litológícos do dis trito (Tabela XXVT)。 $\mathrm{Pb}^{2+}$ parece estar presente nas rochas carbonatí ticas associado aos feldspatos alcalinos, quando então substitui $\mathrm{K}^{\dagger}$, e à apatita, caso em que ocupa a posição do $\mathrm{Ca}^{2+}$ na estrutura dêsse mi. neral.

A média conseguida para essas rochas, 24 ppm, é menor que as encontradas para as rochas de Kaiserstuhl, 55 ppm, e composição média." de Gold, 54 ppm, e muito similar àquela da composição "típica" dêsse Autor, 27 ppm (Tabela XXII)。

Estanho

$\mathrm{Sn}^{4+}$, de raio iônico $(0,71)$ comparável ao do $\mathrm{Fe}^{3+}$ $\mathrm{e}^{\mathrm{T} \mathrm{i}^{4+}}$ (respectivamente 0,64 e 0,68 ), substituiria a Êsses elemen - 
tos (cf. Taylor, 1966, p. 184) na estrutura de minerais máficos. O comportamento do estanho nas rochas ígneas é contudo, muito mais complexo. O seu alto potencial iônico $(i=5,63)$ favoreceria à formação no líquído magmático de complexos do tipo $\left(\mathrm{SnO}_{4}\right)^{4-}$, que por sua vez não seriam aceitos na estrutura dos silicatos face às dificuldades de tamanho e conseqtientemente se acumulariam nas soluções resi. duais (cf. Ringwood, 1955b, p. 247). O comportamento do Sn nas rochas alcalinas de Itapirapuã, quando analisados os valores médios ob tidos para os vários grupos litológicos da província (Tabela XXVI) 。 tem como característica principal uma diminuição gradativa da con centração dêsse elemento passando-se dos têrmos mais básicos dos mais ácidos da série. Nas rochas analisadas, Sn deve estar associado aos minerais portadores de ferro e/ou titânio em sua composição, portanto, aos piroxênios, granadas, titanita, magnetita, etc.

O teor médio em Sn das rochas analisadas de Itapi rapuã é de 11,4 ppm. A julgar pelos dados fornecidos por Turekjan e Wedepohl para os várós grupos de rochas ígneas: rochas ultrabási cas: 0,5 ppm; rochas basálticas: 1,5 ppm; rochas graniticas pobres em cálcio: 1, 5 ppm e rochas graniticas ricas em cálcio: 3, 0 ppm, ve rifica - se que as rochas alcalinas de Itapirapuã (alcalinas em geral?) estão enriquecidas nesse elemento.

Nos carbonatitos de Itapir apuã $\mathrm{Sn}^{4+}$ deve estar concentrado principalmente na magnetita, ocujando a posiçào do $\mathrm{Ee}^{3+}$ na estrutura dêsse mineral. O conteúdo médio em Sn dessas ro chas, 6, 3 ppm. (Tabela XXII) é superior aos valores obtidos por Gold, respectivamente, 1, 1 e 2,5 ppm para a composição "média" e "típi ca."。 


\section{PETROGENESE}

As rochas alcalinas, face à singularidade de sua composição química e mineralógica, têm merecído a atenção de gr an de número de petrôlogos e trabalhos, visando interpretar a sua gênese, são encontrados com freqưểncia na literatura geológica. De maneira geral. duas hipóteses vêm sendo invocadas pelos pesquisa dores para explicar a sua origem: a) teoria de Daly-Shand (Daly, 1933: Shand, 1943 e Shand, 1945)), cujo principal fundamento reside na dessilicatação de magma basáltico ou granítico por efeito de assimillação de material calcário seguido de diferenciação do magma con taminado resultante, e b) teoria de Bowen (Bowen, 1928 e Bowen, 1945), que advoga descendencia das rochas alcalinas a partir da cristalização fracionada de um magma primário de composição basálticica.

Mesmo sem alimentar pretensões de solucionar, de finitivamente, o problema da gênese das rochas alcalinas de Itapirapu.ã, julgamos necessário, em virtude dos dados alcançados no decur so dêste trabalho, tecer algumas considerações quanto à sua origem. Acresce, porém, que não obstante o considerável avanço verifícado nos últimos anos no campo da petrología experimental., os aspectos críticos lingados à formação das rochas alcalinas ainda permanecem in solúveis, fazendo com que as eventuais conclusões extraídas de qual. quer estudo genético dessas rochas baseiem-se, em maior ou menor intensidade, em consider ações especulativas.

$$
\text { Cristalização fir acionada }
$$

A análise dos diversos diagramas de variação quí mica, integrando as figuras descritas no capitulo anterior, parece aw pontar a cristalização fracionada como um dos fatôres atuantes na for mação das rochas alcalinas de Itapirapuã.

Os traçados das diferentes curvas, refletindo comportamento dos elementos principais e dos elementos menores, bem como suas relações cokedumentes ao índice de diferenciação félsi ca de Simpson (1954) nas rochas investigadas, correspondem, em tra ços gerais (cf. Bowen, 1928, pp: 96-110. Nockolds e Allen, 1954, pp. 
253-276: Turner e Verhoogen, 1960, pp.196-200 e Shaw, 1964, pp。 105-106) e salvo algumas exceções, aos que se deveriam esperar do processo de cristalização fracionada de um magma de composição ba sáltica. As curvas crescentes em Si, Al, $\mathrm{Na}, \mathrm{K}$ e Ga contrapõem-se as decrescentes em Fe (total), $\mathrm{Mg}, \mathrm{Ca}$ e Ti。 Dentre os elementos tra ços $\mathrm{Cr}$, $\mathrm{Ni}$, Co e $\mathrm{V}$ estão concentrados nas rochas mais básicas da. série, com V passando por um máximo nas partes iniciais da curva e com $\mathrm{Cr}$ e Ni parecendo cair maîs rảpidamente no seu início. O $\mathrm{Sr}_{\text {, de }}$ cresce suavemente ao longo da série e o Ba, após alcançar concentra. ções mais elevadas na parte intermediária da curva, termina por cair bruscamente até o seu final. As relações Fe/Mg, Y/Ca e Sr/Ca crescem com o aumento do índice félsico, enquanto que as relações $\mathrm{Cr} / \mathrm{Fe}$ e Co/Fe diminuem.

Evidência indicativa de cristalização fracionada pode também ser encontrada no diagrama triangular Fe:Alk:Mg da Fig. 20. Os portios projetados neste diagrama exibem grande regularidade em sua distribuição, observando-se que a curva obtida tem, ao lado da concavidade voltada para o vértice $\mathrm{Mg}$, uma orientaçăo marcada por forte enriquecimento em álcalis, em detrimento de ferro e magnésio. Esse traçado parece compatível com o que se deveria esperar de uma sequência de rochas fortemente diferenciadas.

Ao lado das feições apontadas acima ocorrem ou tras, de natureza mineralógica, representadas principalmente pela sequência de cristalização dos piroxeñios. Os diversos membros des sa série, passando de soda-augita a egirina, funcionam como verda. deiros indicadores do progressivo enriquecimento dêsses minerais em álcallis no curso de differenciação da série.

Não obstante a cristalização fracionada tenha sido um dos processos atuantes, senão o principal processo de formação das alcalinas de Itapirapuã, ela em si não explica alguns aspectos li gados à. formação dessas rochas, como: a) o comportamento anomaLo de alguns elementos traços ( $L a, M o, S n$, Be e Cu) no transcorrer do processo evolutivo do maciço, e b) o fato de que no diagrama ter. nário $\mathrm{NaAlS} \mathrm{O}_{4}: \mathrm{KAlS}_{4}{ }^{\circ \mathrm{SiO}_{2}}(\mathrm{Fig} \cdot 30)$, sistema do resíduo" petrogenético de Bowen (Bowen, 1937: Schairer, 1950), as rochas mais dife. renizudas da província e portadoras de maís de $80 \%$ de minerais siá. Vicos normativos, exclusive anortita e cor indon, em lugar de se locaJizarem dentro do vale de baixas temperaturas da superfície de fusăo, 


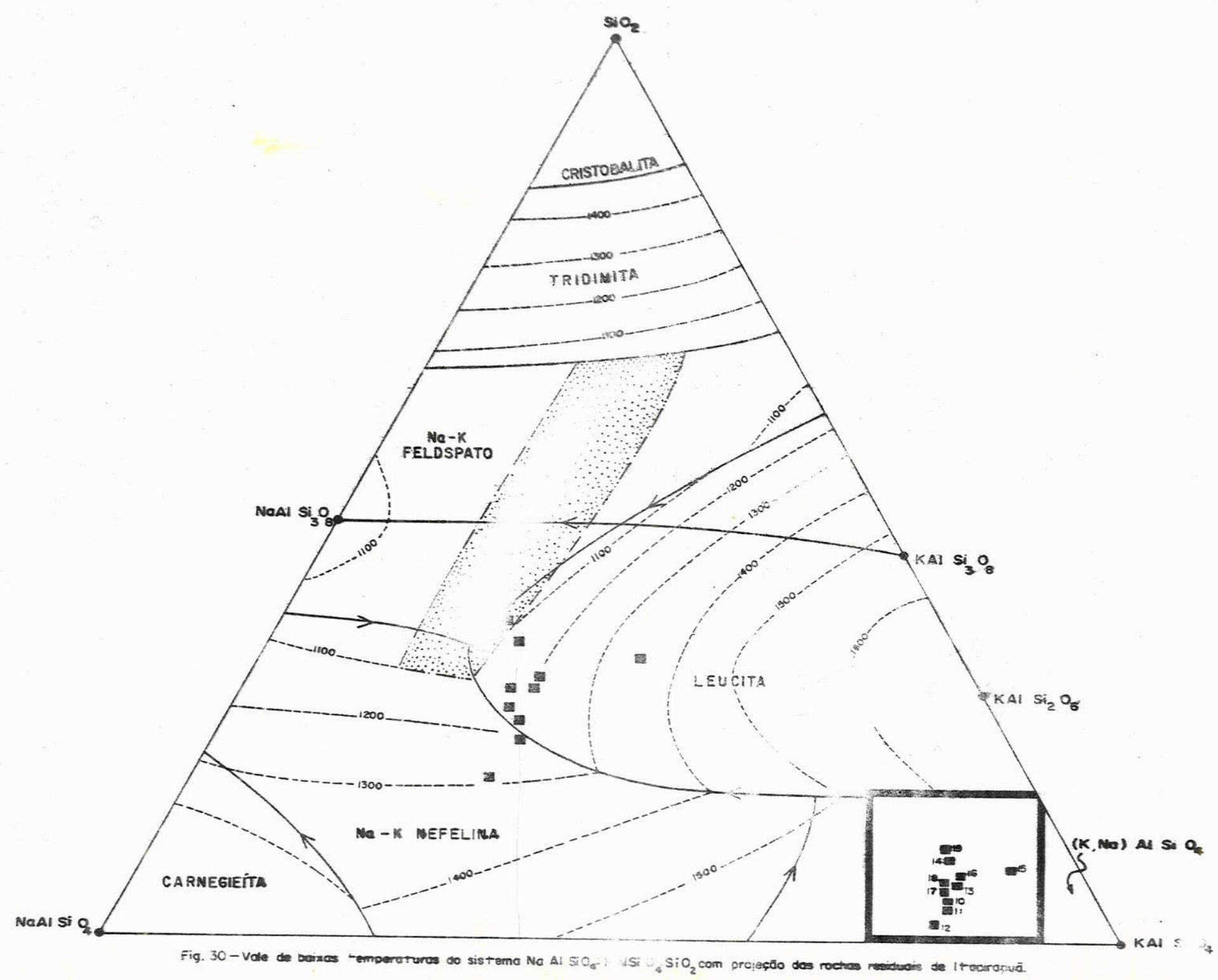


como era lícito esperar-se de líquidos magmáticos residuais, estao situadas fora dêle, a exceção do tinguaíto da amostra 18. Este fato, refletindo o caráter marcadamente insấturado e a riqueza em álcallis dessas rochas, constitui forte indício quanto à existência de uma interação de processos na formação das eruptivas alcalinas de Itapirapuã.

A natureza do material primário

Tendo em vista as conclusões alcançadas por

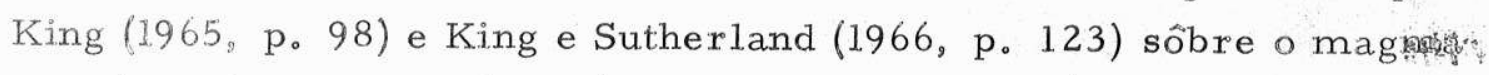
gerador, de composição próxima aos melteigitos/melanefelinitos, das ruchas alcalinas de Uganda e, considerando a posição ocupada pelo biotita melteigito de Itapirapuã nos diagramas de variação elaborados, tentamos derivar, por um processo normal de cristalização fracionada, tôdas as demaîs rochas da província a partir do biotita melteigito, re correndo-se para tanto às composições médias fornecidas na Tabela XXVI e ao gráfico de adição-subtração idealizado por Bowen (1928, p. 76). Os resultados obtidos, contudo, constantes da Tabela XXVII, apontam a impraticabilidade dessa derivação face à composição mineralógíca normativa do material removido, de formação improvável nas condiçōes de cristalização natural.

O paralelismo que se verifica entre a distribuição dos vários têrmos da linhagem alcalina, bem estudada na literatura mundial, com a encontrada em Itapirapuã, constitui, ao lado da con . centração elevada de alguns elementos traços nos têrmos petrográfícos maís básicos da província, feições sugestivas de que essas rochas poderiam provir de um magma primário de composição basáltica. A crença de que o magma gerador das rochas alcalinas é de naturezaba sáltica vem sendo modernamente defendida por Williams (1959), Erickson e Blade (1963) e Verwoerd (1966).

Se por um lado existem indícios apontando para de ierminada fonte geradora das rochas alcalinas, nada se conhece sốbł $\mathrm{e}$ mecanismo do processo que leva à sua formação. Sabe-se tão sò mente que há uma aparente impossibilidade (cf。 King e Sutherland, 1960 , po 717: Bailey e Schairer, 1966, p。155) de obter-se magmas alcalinos fortemente insaturados, como é o caso dos melteigitos, por simples cristalização fracionada de magma basáltico。King (1965, p。 
TABELA XXVI

Composição média das principais rochas de It a pirapuã

\begin{tabular}{lrrrrr}
$\%$ Pêso & \multicolumn{1}{c}{1} & \multicolumn{1}{c}{2} & \multicolumn{1}{c}{3} & \multicolumn{1}{c}{4} & \multicolumn{1}{c}{5} \\
$\mathrm{SiO}_{2}$ & 42,57 & 44,28 & 48,13 & 52,99 & 54,35 \\
$\mathrm{TiO}_{2}$ & 2,86 & 2,19 & 1,15 & 0,41 & 0,47 \\
$\mathrm{Al}_{2} \mathrm{O}_{3}$ & 16,76 & 18,06 & 18,87 & 22,45 & 22,72 \\
$\mathrm{Fe}_{2} \mathrm{O}_{3}$ & 5,27 & 6,84 & 6,58 & 3,85 & 2,41 \\
$\mathrm{FeO}$ & 4,74 & 2,03 & 1,44 & 0,87 & 1,55 \\
$\mathrm{MgO}$ & 3,98 & 3,30 & 1,33 & 0,24 & 0,15 \\
$\mathrm{CaO}$ & 14,05 & 12,65 & 8,64 & 2,85 & 1,50 \\
$\mathrm{Na}_{2} \mathrm{O}$ & 7,42 & 7,10 & 7,70 & 8,94 & 10,33 \\
$\mathrm{~K}_{2} \mathrm{O}$ & 2,35 & 3,54 & 6,15 & 7,38 & 6,50
\end{tabular}

ppm

$\begin{array}{lrrrrr}\mathrm{Be} & & 11 & 8,3 & 5,7 & 10,2 \\ \mathrm{Ga} & 18 & 22 & 26 & 28 & 36 \\ \mathrm{Cr} & 96 & 5 & 10,3 & 2,8 & 1,3 \\ \mathrm{~V} & 168 & 230 & 225 & 92 & 49 \\ \mathrm{Mo} & 11 & & 10,5 & 5,6 & 11,5 \\ \mathrm{Nb} & 170 & 200 & 231 & 108 & 165 \\ \mathrm{Sn} & 19 & 25 & 17 & 9 & 5,5 \\ \mathrm{Ni} & 60 & 11 & 8,5 & 3,6 & 3,9 \\ \mathrm{Co} & 13 & 13 & 5,8 & 3 & 2,8 \\ \mathrm{Cu} & 150 & 160 & 101 & 87 & 95 \\ \mathrm{Sc} & 26 & 8,6 & 1,8 & 2,8 & 1,3 \\ \mathrm{Zr} & 340 & 500 & 478 & 376 & 535 \\ \mathrm{Y} & 62 & 115 & 100 & 29 & 27 \\ \mathrm{La} & 420 & 420 & 141 & 130 & 162 \\ \mathrm{Sr} & 920 & 700 & 661 & 707 & 455 \\ \mathrm{~Pb} & 38 & 38 & 44 & 42 & 83 \\ \mathrm{Ba} & 380 & 2000 & 3371 & 2142 & 150\end{array}$

Normas moleculares

\begin{tabular}{|c|c|c|c|c|c|c|}
\hline Or & & - & 6,95 & 24,18 & 43,37 & 38,36 \\
\hline $\mathrm{Ab}$ & & -30 & - & - & 8,64 & 11,53 \\
\hline An & & 5,28 & 6,95 & & - & - \\
\hline Lc & & 10,90 & 11,12 & 10,25 & - & - \\
\hline $\mathrm{Ne}$ & & 34,08 & 32,38 & 33,51 & 35,69 & 37,49 \\
\hline A. & & - & - & 2,77 & 0,92 & 0,91 \\
\hline & Wo & 11,48 & 9,51 & 4,29 & 0,70 & 1,97 \\
\hline $\mathrm{Di}$ & En & 9,90 & 8,20 & 3,70 & 0,60 & 0,40 \\
\hline & $\mathrm{Fs}$ & - & - & - & - & 1,72 \\
\hline Wo & & 15,43 & 13,80 & 14,04 & 5,22 & 1,16 \\
\hline $\mathrm{Mt}$ & & 6,96 & 0,23 & 1,39 & 1,62 & 0,46 \\
\hline $\mathrm{Hm}$ & & 0,48 & 6,72 & 4,64 & 2,40 & \\
\hline II & & 5,47 & 4,10 & 2,13 & 0,76 & 0,91 \\
\hline$\%$ & $\cos$ & 50,26 & 57,40 & 67,94 & 87,70 & 87,38 \\
\hline
\end{tabular}

1. Biotita melteigito. (Am, 1).

2. Melanita malignito. (Am, 2).

3. Melanita-nefelina sienitos. (Am. 3 a 9).

4. Nefelina sienitos. (Am. 10 a 17).

5. Tinguaítos. (Am, 18 e 19). 
TABELA XXVII

Composição química e norma molecular do material a ser extraído do biotita melteigi to para obter se as demais rochas da série

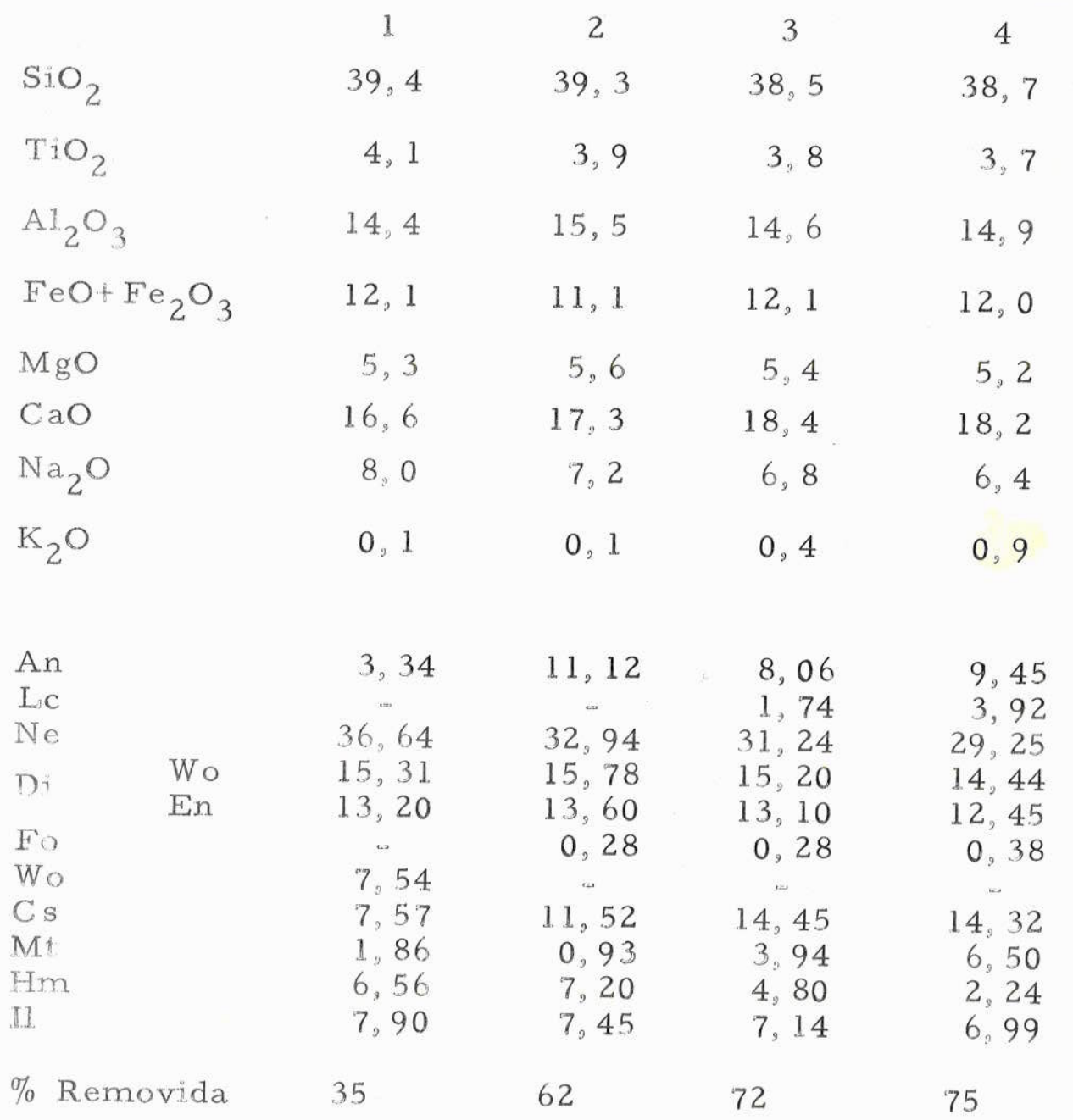

1. Material mínimo a ser removido para obter se o mela nita malignito.

2. Material mínimo a ser removido para obter - se a média dos melanita - nefelina sienitos.

3. Material mínimo a ser removido para obter-se a média dos nefelina sienitos.

4. Material mínimo a ser removido para obter - se a média dos tinguaítos. 
98), analisando mais detidamente o problema, vai mais além ao afir mar de forma enfática ser inviável que a derỉvação acima tome lugar por qualquer processo, ou combinação de processos, afetando um magma primário basáltico.

Rochas "miasquiticicas", como as de Itapirapuã (ver p. 86), são frequentemente interpretadas na literatura (cf. Barth, 1962, pp.200-201; Heiex e Taylor, 1964, p.200, e outros) como ten do südo formadas através da assimilação de calcário por meło de mag ma subalcalino. Este fato, aliado às consideraçōes formuladas anteriormente neste capítulo, e como a existência de calcárı̈o na região e nas imediações do maciço investigado e a presença nas rochas alcalinas de mineralogia altamente enriquecida de minerais cálcicos, levou - autor a estudar a possibilidade de derivar as várias rochas da provincia a partir de um magma de composição olivina basalto, acrescí do de material carbonático em proporções variadas. Os resultados al cançados mostraram-se contudo, pouco esclarecedores. Larsen(1942, pp.39-43), interpretando a gênese do macỉço alcalino de Iron Hill, Colorado, Estados Unidos da América, usou de idểntico recurso e che gou à conclusão que as rochas ali existentes deveriam ter-se originado a partir da cristallização fracionada de um magma basáltíco, modi-fỉcado pela as similação em profundidade de material calcári̊o. Não obs ta: e assimilação possa contribuir para a formação das rochas alcalinas convérn notar que, segundo Macdonald (1949, pp.1581 e 1585), a simples adição de calcário a magma basáltíco, seguida de diferenciação do material contaminado resultante, não é suficiente para produz r rochas alcalinas de caráter fortemente insaturado.

Dos motivos expostos acima, somos levados a acredivar que diversos processos intervieram na formação das rochas que constituem o maciço de It apirapuã. Assim, ao lado da cristalização fracionada, parece ter ocorrido ação de processos metassomáticos promovendo, seja a formação, dentxo do corpo, de variedades petrográficas enriquecidas em sódio, caso particular do cancrinita mariu. poljto, seja a formação de produtos alcalinizados (fenitizados), nas imediações da zona de contato do maciço alcalino, junto às encaixantes de natureza granitica. Processos envolvendo assimilação de mate rial carbonático muito possivelmente também contribuiram para a gê zese das eruptzvas de Itapirapuã e a abundância de minerais çlcicos nessas rochas, em especial no wollastonita-melanita-nefelina sienito, 
acrescido da presença de calcários aflorando na região e à pequena distância do corpo alcalino (ver mapas das Figs。 2 e 3) podem ser in. terpretadas como feições sugestivas daquele fato. As similação de frações crostais siálicas podem também ter ocorrido na região de conta to do corpo alcalino levando à formação de rochas altamente potássi. cas, como é o caso do pulaskito. Em adição a êsses processos, poder - se-ia ainda acrescentar o papel desempenhado pelos agentes voláteis no curso de evolução das rochas da província, A importância dos processos de emanação, como fator dominante na redistribuição dos ele= mentos químicos no interior do magma, na formação de rochas alcali nas foi amplamente considerada por Vlasov et al. (1966, pp.589-592) em seu trabalho sôbre o maciço alcalino de Lovozero, na Península de Kola. Rússia. Nas rochas de Itapirapuã, a ação dos voláteis é evidenciada pela presença constante de cancrinita como mineral de alter ação da nefelina, pela abundâncía de veios pegmatíticos cortando os nefelina sienitos e pela frequência de concentrações uniminerálicas, comumente de dimensões centimétrìcas, de piroxênio egirínico e biovita no corpo dessas rochas.

Os fatos apresentados levaram o autor tring - maciço alcalino de Itapirapuã uma interpretação genética baseada na cristalização fracionada de um magma primário de natureza basáltica, modificado pela interação dos seguintes processos: assimilação de cál cário e material crostal siálico, metassomatose e ação de agentes voláteis.

Formação dos carbonatitos

Duas opiniões contrastantes envolvendo as relações genéticas entre rochas alcalinas/carbonatitos são citadas na literatura geológica. A primeira delas, defendida por Brbgger (1921), von Eckermann (1948), Holmes (1950), etc。, parte da suposição que o mag ma primário dos complexos alcalinos possui composição carbonática, enquanto que a segunda hipótese, apoiada por King (1949), King e Sutherland (1960), Tilley (1958) e outros, procura interpretar os carbonatitos como tendo sido formados a partir da consolidação de líquídos residuais do magma alcalino. A esta segunda hipótese correspondem cumumente os modos de ocorrếncia dos corpos encontrados no 
campo. Um outro aspecto crítico ligado à gênese dessas rochas diz respeito à fonte do $\mathrm{CO}_{2}$. $\mathrm{Na}$ opinião de Verwoerd (1966, p.197) há sòmente duas alternativas para a solução do problema: a) existência dé carbono juvenil em quantidade suficiente na parte da crosta da terra ou manto onde os magmas são gerados e b) volume de $\mathrm{CO}_{2}$ no magma primário aumentado por efeito de assimilação de material carbonátim co. Analisando detidamente a questão, com vistas ao estabelecimen to do provâvel modo de origem dos carbonatitos sul africanos, Ver woerd (op. cit., p. 202) chegou à conclusão que o magma basáltico pode conter carbono primário em proporção suficiente para satisfa zer à formação dos carbonatitos. Todavia, faz-se necessário que ês se $\mathrm{CO}_{2}$ venha a se concentrar nas frações residuais por efeito de di ferenciação magmática em condições tais que impeça o seu escape。

A fonte de $\mathrm{CO}_{2}$ para a formação dos carbonatitos de Itapirapuã poderia ser encontrada, quer junto ao magma basáltico pri mário, provàvelmente o material gerador do complexo alcalino, quer junto ao calcário vizinho, admitida a sua assimilação。

O modo de ocorrência dos carbonatitos de Itapira puã, pequenos veios irregulares cortando os nefelina sienitos, demons tra de forma insofismável a sua formação tardi.a. O reconhecimento, ao microscópio, de cristais corroídos de feldspato alcalino circundados por calcita leva-nos a acreditar (cf. Kukharenko e Dontsova, 1964) de que o "emplacement" dessas rochas deu-se, pelo menos em parte, por substituição seletiva da rocha preexistente. Esse processo de car bonatização parece ter sido, segundo alguns Autores, o fator respon sável pela formação dos carbonatitos (metacarbonatitos de conformi dade com a terminologia de Verwoerd, 1966, p. 189) de vários distritos alcalinos (Goudini e Kruidfontein no continente sul africano; e de Fen na Noruega, etc。).A hipótese de formação de carbonatitos por substituição de rochas silicatadas, por efeito de soluções pneumatolí tico-hidrotermais, vem sendo defendida por alguns pesquisadores rus sos, destacando-se entre êles: Kranck, Borodin, Kukharenko, etc.

A composição espectográfica dos carbonatitos de Itapirapuã, caracterizada sobretudo por concentrações elevadas em $\mathrm{Nb}, \mathrm{Cu}, \mathrm{La}, \mathrm{Sr}$ e Ba, parece apontar muito mais para uma forma ção metassomática dessas rochas, do que pròpriamente uma origem ligada à cristalização de um líquido magmático tesidual, de compo-. 
sição carbonática. Essa interpretação é postulada tendo-se em vista a distribuição anômala de alguns elementos traços (Be, Ga, Mo, Sn e $\mathrm{Pb}$ ), esperados, face ao seu comportamento químico teórico, de se acumularem no curso da diferenciação magmática.

$$
\text { Formação do corpo de magnetita }
$$

As inúmeras dificuldades comumente encontradas na distinção entre os depósitos originados por segregação magmática e os formados por processos de natureza hidrotermal, aliadas à pou ca atenção que dispensamos ao estudo das relações texturais do miné rio de ferro tornam problemáticas quaisquer tentativas de se estabelecer, de forma definitiva, a gênese do corpo de magnetita de Itapira puà. Entretanto, a associação intima com rochas eruptivas de compó siçăo sienítica constitui, de conformidade com Park e MacDiarmid (1964,pp.215-216), feição sugestiva de que a concentração de magneti ta, situada na parte sul do maciço de Itapirapuã, deu-se por influência de processos de segregação magmática.

Face à limitação dos dados postos à nossa disposi ção, julgamos também prematuro emitir opinião definitiva sôbre a cris talização da magnetita no corpo da rocha. Contudo, as dimensões cen timétricas frequentemente exibidas por êsse mineral, refletindo maior fluidez do líqưido magmático, parecem apontar no sentido de $\underline{u}$ ma cristalização tardia para a magnetita. Da mesma forma, pouco se pode assegurar quanto ao mecanismo que levou a essa concentração de magnetita, podendo o mesmo ter-se dado por segregação gravitativa, imiscibilidade líquida ou mesmo "filter pressing". Problema análogo se verifica quanto ao modo de "emplacement" dêsse material, se consolidado "in loco" ou injetado.

$$
\text { Fentitiz ação }
$$

Alterações metassomáticas das encaixantes, provo cadas por soluções emanadas das rochas alcalinas foram observadas nas bordas NE e SW do corpo, não obstante possam ter ocorrido em tôda a extensão de sua zona de contato. A profunda alteração intempé rica a que estão sujeitas as rochas da região, aliado ao intenso cizalha mento das encaixantes na zona de contato com o corpo alcalino, constituem os fatôres responsáveis pelo nưmero escasso de amostras fres cas aŕ encontradas e tornam ainda impraticáveis quaisquer tentativas de delimisação da área afetada pela ação metassomática. 
bidas pelas rochas encaixantes, na região de contato com o maciço alcalino, são indicativas da existência de um processo de alteração, que se identifica com o descrito e definido originalmente por Brög ger (1921, p. 171) e, mais tarde, estudado em todos os seus pormenores por von Eckermann (1948, p, 27), como fenitização. Contudo, em Itapirapuã, a ação dêsse processo parece ter sido incipiente e em lugar dos fenitos, como definidos pelo primeiro Autor, as rochas encaixantes ainda conservam quartzo, se bem que em menor porcen tagem, em sua composição.

Partindo-se do pressuposto que as rochas graníticas que servem de encaixante ao maciço alcalino tivessem originalmente e nas circunvizinhanças dêste corpo, composição uniforme , for am analisadas quimicamente duas amostras, a primeir a coletada a uma distância aproximada de 1500 metros da zona de contato e a segunda dentro desta região (respectivamente, Am. $\underline{41}$ e $\underline{42}$ da Fig. 4), com o objetivo de se estabelecer as possíveis variações quími cas e mineralógicas causadas nessas rochas pelo processo de feniti zação. Os dados coligidos (Tabela XXVIII) são indicativos da exis tência de uma ação metassomática aditiva para os valores de alumi na, ferro, magnésio, cálcio, sódio e fósforo e, em contraposição , uma subtrativa para os valores de sílica, titânio e potássio, no sen tido da amostra localizada na zona de contato do maciço. Condicio nadas a essas variações, processaram-se, em sentido idêntico e en volvendo principalmente os constituintes félsicos, mudanças consi deráveis na composição mineralógica, acarretando diminuição progressiva dos teores de quartzo e microclínio e aumento do conteúdo de plagioclásio dessas rochas, passando-se de adamellito (rocha pouco afetada) para granodiorito (rocha fenitizada). Observou-se também que o teor de anortita do plagioclásio, determinado através de técnicas microscópicas e calculado a partir de normas molecula res, permaneceu pràticamente constante nas duas amostras. Ao la do dessas transformações teve lugar uma nova alteração, de suma importância como feição indicativa de um metassomatismo aditi vo de natureza sódico-férrica, transformando os minerais ferromag nesianos preexistentes, hornblenda verde comum e biotita, em anfi bólio sódico (Fotomicrografias 17 e 18). Este mineral, de hábito acícular, formando comumente agregados fibrorradiais e que já 
TABELA XXVIII

Adamellito e Granodiorito fenitizado

\section{Composição quúmica}

\begin{tabular}{|c|c|c|c|c|c|}
\hline$\%$ Pêso & 41 & 42 & ppm & 41 & 42 \\
\hline $\mathrm{SiO}_{2}$ & 70,4 & 60,0 & $\mathrm{Be}$ & 3,6 & 5,4 \\
\hline $\mathrm{TiO}_{2}$ & 0,53 & 0,16 & $\mathrm{Ga}$ & 14 & 22 \\
\hline $\mathrm{Al}_{2} \mathrm{O}_{3}$ & 14,1 & 17,0 & $\mathrm{Cr}$ & 18 & 36 \\
\hline $\mathrm{Fe}_{2} \mathrm{O}_{3}$ & 0,92 & 2,60 & $\mathrm{~V}$ & 30 & 74 \\
\hline $\mathrm{FeO}$ & 1,80 & 3,38 & Mo & nd & 5 \\
\hline $\mathrm{MnO}$ & $\operatorname{tr}$ & tr. & $\mathrm{Nb}$ & 8 & 25 \\
\hline $\mathrm{MgO}$ & 0,89 & 2,11 & $\mathrm{Sn}$ & 4 & 9,5 \\
\hline $\mathrm{CaO}$ & 3,22 & 4,90 & $\mathrm{Ni}$ & 3,6 & 13 \\
\hline $\mathrm{Na}_{2} \mathrm{O}$ & 3,33 & 4,66 & Co & 5 & 10 \\
\hline $\mathrm{K}_{2} \mathrm{O}$ & 4,16 & 3,48 & $\mathrm{Cu}$ & 140 & 140 \\
\hline $\mathrm{H}_{2} \mathrm{O}^{+}$ & 0,22 & 0,25 & $\begin{array}{l}\mathrm{Sc} \\
\mathrm{Zr}\end{array}$ & 230 & 340 \\
\hline $\mathrm{H}_{2} \mathrm{O}^{-}$ & 0,20 & 0,25 & $\mathrm{Y}$ & 9,5 & 40 \\
\hline $\mathrm{P}_{2} \mathrm{O}_{5}$ & 0,52 & 0,78 & La & 88 & 180 \\
\hline $\mathrm{CO}_{2}$ & tr. & 0,15 & $\mathrm{Sr}$ & 390 & 490 \\
\hline & & & & 720 & \\
\hline
\end{tabular}

\section{Norma molecular}

\begin{tabular}{|c|c|c|c|c|c|c|}
\hline & & 41 & 42 & & 41 & 42 \\
\hline \multicolumn{2}{|l|}{$\mathrm{Qz}$} & 27,84 & 7,44 & Quartzo & 26,8 & 12,0 \\
\hline \multicolumn{2}{|l|}{ Or } & 24,46 & 20,57 & Microclínio & 31,8 & 17,7 \\
\hline \multicolumn{2}{|l|}{$\mathrm{Ab}$} & 28,30 & 39,30 & \multirow{2}{*}{$\begin{array}{l}\text { Oligoclásio } \\
\left(\mathrm{An}_{22} \text { e } \mathrm{An}_{28}\right)\end{array}$} & \multirow[b]{2}{*}{31,4} & \multirow[b]{2}{*}{52,7} \\
\hline An & & 11,12 & $.15,29$ & & & \\
\hline \multirow{4}{*}{$\mathrm{Di}$} & \multirow[b]{2}{*}{ Wo } & \multirow[b]{2}{*}{0,26} & \multirow[b]{2}{*}{0,66} & Biotita & 6,4 & 8,9 \\
\hline & & & & Hornblenda & 0,1 & 1,9 \\
\hline & En & 0,50 & 0,90 & Riebeckita & 0,2 & 3,6 \\
\hline & Fs & 0,81 & 1,63 & Calcita & tr. & 0,9 \\
\hline \multirow[b]{2}{*}{ Hy } & En & 1,32 & 4,40 & Titanita & 0,6 & 0,8 \\
\hline & \multirow[t]{2}{*}{$F \mathrm{~s}$} & 1,70 & 3,17 & Opaco & 0,7 & 0,9 \\
\hline Mt & & 1,39 & 3,71 & Epídoto & 0,6 & 0,4 \\
\hline II & & 1,06 & 0,30 & Apatita & 0,3 & 0,2 \\
\hline Ap & & 1,34 & 1,68 & Zircão & tr. & tr. \\
\hline $\mathrm{Cc}$ & & - & 0,30 & Sericita & 0,3 & tr. \\
\hline \multirow[t]{2}{*}{$\mathrm{H}_{2} \mathrm{O}$} & & 0,42 & 0,50 & Clorita & - & tr. \\
\hline & & & & Allanita & 0,1 & tr. \\
\hline
\end{tabular}

Total $100,29 \quad 99,72$

Analistas: Elementos principais - Benedito Alves Ferreira (I. G. G.).

Elementos traços - Cláudio Vieira Dutra (I. T.I.). 
havia sido identificado na amostra de adamellito ocorre no grarrodzo rito fenitizado ocupando aproximadamente $3,6 \%$ em volume da rocha. Ao microscópio, destaçamse prontamente dado o seu caráter pleocrö $\operatorname{co} \operatorname{com} \mathrm{X}=\mathrm{azul}, \mathrm{Y}=$ violeta e $\mathrm{Z}=$ incolor a amarelo. Sua birtefrin gência é muito baixa, fortemente anômala, $2 \mathrm{~V}$ é próximo a $90^{\circ}$ e a extinção quase paralela, com $X$ no alongamento. $O$ plano dos eixos ópticos é normal à face (010) e os índices de refraçăo $\mathrm{N}_{x}: 1.672$ e $\mathrm{N}_{\mathrm{z}}=1,678$. Com base na classificação de anfỉbólios sódicos adotada por Heinrich (1965, p. 272) parece trataruse de riebeckita. A presen ça de riebeckita em rochas fenitizadas tem sido obsexvada em váruas províncias alcalinas mundiais, merecendo destaque especial a de An tápolịs no Estado de Santa Catarina, recentemente descrita por M@l. cher e Coutinho (1966), onde o mineral atinge até 4, 4 em volume da. rocha. Em algumas amostras, essa ação metassomắtica resultou na formação de piroxênio sódico, em detrimento de anfibólio, a partir do mineral ferromagnesiano preexistente. Este pirroxênio, a julgar por seus dados ópticos, $\mathrm{N}_{\mathrm{y}}=1,735$ a $1,752, \mathrm{X}: \mathrm{c}=10$ a $15^{\circ} \mathrm{e}$ pleo croísmo marcante $\operatorname{com} X=$ verde, $X=$ verde amarelado $e z=$ amare lo esverdeado tem composição situada no campo da egirinawaugtua, com aproximadamente 27 a $40 \%$ da molécula do primeiro. Além de formar-se às expensas da biotita, êste mineral tem sido tambern ju.. dentiticado preenchendo zonas de fraturas de cristais prefertos,bem como pequenos velos cortando a rocha fenitizada. Concomitantemente às modificações mineralógicas mencionadas, variaçoes dexturas o w correram em resposta a esforços dinâmicos, provocando o aparect mento de feiçöes cataclásticas, a saber, extinçäo ondulante do quart zo, fraturamento dos gxânulos e encurvamento das tinhas de cliva . gem dos feldspatos, etc. Sericitização dos cristais de feldspatos. consequência da hidratação parcial a que essas rochas for am subme ticas, é freqtente e constitui, ao lado das anteriores, feição caracte rística dos primeiros estágios de fenițização (cf. von Eckermann, 1948, p. 29).

Do ponto de vista químico (elementos traços) verifi cou-se que, com exceção do cobre, cujo teor foi mantido, todos os demais elementos analisados tiveram seus valores majorados na aw mostra fenitizada em relação à inalterada. 
la XXIX), as modificações químicas exibidas pelas rochas de Itapira puã são concordantes, no seu sentido evolutivo, com as processadas nas encaixantes granodioríticas do maciço alcalino de Iivaara, Kuusa mo, Finlândia (tuehijurvi, 1960, p. 27). Contudo, observa-se que na primeira ocorrência a porcentagem em pêso do material acrescentado no transcurso da fenitização é um pouco menor que a removida , respectivamente, 9, 32 e 11,45, enquanto que no distrito de Iivaara o corre o inverso, com a porcentagem dos elementos adicionados alcan çando 10,19 para 9,91 da subtraída. Ainda dentro dessa análise com parativa, qualquer explicação para os resultados discordantes obti. dos para o potássio nas duas ocorrências, apresenta sérias dificulda des, visto que até o presente momento, o comportamento dêsse ele mento durante a fenitização permanece discutível, face às conclusões antagônicas alcançadas por Brögger (1921, p. 173) e Saether (1957, p. 23) em seus estudos na região de Fen, Noruega. O primeiro dêsses Autores observou que, ao lado da sílica, potássio tinha decrescido no decurso do processo, enquanto que sódio, alumina e cálcio tinham aumentado. Já Saether (1957) admitiu que, em contraposição ao decrés cimo da sílica, teria havido aumento nos teores de sódio, potássio, a lumina, cálcio e dióxido de carbono. Admitiu também que titânio, fer ro e magnésio não sofreram qualquer transporte significativo duran. te o citado processo. Ao lado dêsse fato, convém igualmente frisar, segundo Melcher e Coutinho (1966, p. 67; transcrito de von Eckermann, 1948), que a natureza e intensidade das trocas metassomáticas podem diferir nas diversas ocorrências, pois dependem da composição ini cial das rochas encaixantes, das soluções alcalinas, além da fatôres físico-químicos ainda pouco investigados. Frise-se também que, em razão da heterogeneidade que em geral caracteriza os corpos de natu reza metassomática e da precariedade dos dados que dispomos, não nos encontramos em condições de traçar um rumo definitivo para as mudanças químicas que teriam se processado nas rochas de Itapira puã, assim que os comentários proferidos atrás devem ser tomados, tão sòmente, como primeira aproximação. Contudo, é particularmen te interessante, face às conclusões apresentadas por McKie (1966, p. 293) em recente trabalho sôbre o quimismo do processo de fenitiza ção, que as variações químicas notadas nas amostras $\underline{41}$ e $\underline{42}$, em es pecial às relativas ao decréscimo de sílica e enriquecimento em alu- 


\section{TABELA XXIX}

Itap rapuã

\begin{tabular}{|c|c|c|c|c|c|c|c|c|c|c|}
\hline & $\mathrm{S}_{2}$ & $\mathrm{TiO}_{2}$ & $\mathrm{Al}_{2} \mathrm{O}_{3}$ & $\mathrm{Fe}_{2} \mathrm{O}_{3}$ & $\mathrm{FeO}$ & $\mathrm{MgO}$ & $\mathrm{CaO}$ & $\mathrm{Na}_{2} \mathrm{O}$ & $\mathrm{K}_{2} \mathrm{O}$ & $\mathrm{P}_{2} \mathrm{O}_{5}$ \\
\hline $\begin{array}{l}\text { Granodiorito } \\
\text { fenitizado }\end{array}$ & $+60,0$ & to, 16 & $+17,0$ & $+2,60$ & $+3,38$ & $+2,11$ & $+4,90$ & $+4,66$ & $+3,48$ & $+0,78$ \\
\hline Adamellito & $+70,4$ & +0.53 & $+14,1$ & +0.92 & $+1,80$ & $+0,89$ & $+3,22$ & $+3,33$ & $+4,16$ & $+0,52$ \\
\hline Diferença & $-10,4$ & $-0,37$ & +2.9 & $+1,68$ & $+1,58$ & $+1,22$ & $+1,68$ & $+1,33$ & $-0,68$ & $+0,2$ \\
\hline
\end{tabular}

Iivaara

\begin{tabular}{|c|c|c|c|c|c|c|c|c|c|c|}
\hline Fenito & $+63,19$ & $+0,49$ & $+16,52$ & +1.87 & $+1,35$ & +0.71 & $+2,59$ & +7.76 & $+4,42$ & $+0,22$ \\
\hline Granodiorito & $+73,10$ & $+0,15$ & $+13,87$ & $+0,64$ & $+0,78$ & $+0,43$ & $+1,62$ & $+4,49$ & $+3,69$ & $+0,07$ \\
\hline ferença & $-9,91$ & $+0,34$ & 065 & -1.23 & +0.57 & +0.28 & +097 & $+32=$ & $+0,73$ & $+\mathrm{O}_{2}$ \\
\hline
\end{tabular}


mina, cálcio, ferro e sódio, estão dentro do esquema geral de tro cas metassomáticas estabelecido por aquêle Autor.

Análise comparativa com ocorrências congêneres Ocorrências brasileiras

A análise comparativa, reunindo as eruptivas alcalinas de Itapirapuã e outras do Brasil meridional, encontra sérias di ficuldades em razão de dois aspectos: a) informações geológicas rela tivas às diversas ocorrências alcalinas brasileiras são comumente deficientes e b) observa-se carência quase total de dados químicos.

O maciço de Itapirapuã, face às suas particularida des mineralógico-petrográficas, reflexos do caráter fortemente insatu rado e da riqueza em cálcio e álcalis ocupa posição singular entre as demais províncias alcalinas brasileiras. Contudo, alguns traços de identidade poderão ser encontrados entre essa ocorrência e as de Jacupiranga, Serrote e Anitápolis, tomando-se por base: a associação mine ralógico-petrográfica e a sua situação geológica.

Jacupiranga, Serrote e Anitápolis, a exemplo de Ita pirapuã, são distritos alcalinos caracterizados por um conjunto de ro chas marcadamente insaturadas, desprovidas ou não de feldspatos, e de composição variável passando de intermediárias a básicas e mes mo ultrabásicas. Têm ainda em comum a presença de carbonatitos, 으 cupando aproximadamente as suas partes centrais, além do fato da apatita existente nessas rochas dar origem por ação intempérica a con centrações de fosfato residual, que, eventualmente, caso de Jacupiran ga e Serrote, podem apresentar interêsse comercial.

Processos de fenitização, afetando a rocha encaixante de natureza granítica-granodiorítica, for am também reconheçidos em Anitápolis (Melcher e Coutinho, 1965) e Jacupiranga (Melcher, 1954). A semelhança do acontecido em Itapirapuã, o metassomatismo nesses distritos parece ter sido incipiente, limitando-se tão sòmente a provo car algumas modificações texturais e mineralógicas nas rochas encaixantes, sem ter contudo, conduzido à formação de fenitos como for am descritos originalmente por von Eckermann (1948). A julgar por informações ópticas, extraídas do estudo microscópico de minerais de ro- 
chas, a metassomatose em Anitápolis (ㄷ. Melcher e Coutinho, 1965, p. 88) teve caráter pronunciadamente sódico. Todavia, a falta de dados químicos impede que se tenha uma caracterização mais completa do fenômeno, tornando consequentemente impraticável um confron to mais direto com o ocorrido nas rochas de Itapirapuã.

Quanto à gênese, pouco se pode dizer sôbre os distritos de Jacupiranga, Anitápolis e Serrote, visto que êles até o presente momento, face à inexistência de dados químicos, não for am in vestigados do ponto de vista petrológico. Apenas algumas rápidas con sider ações foram formuladas por Melcher (1954, pp. 16-18) e Melcher e Coutinho (1966, pp.87-91), sem ter contudo levado a uma conclu são definitiva sôbre o assunto.

Ocorrências estrangeiras

Um exame rápido da literatura mundial mostra a se melhança mineralógico-petrográfica existente entre a província de Ita pirapuã e numerosas outras espalhadas pelo mundo, sobretudo, as localizadas no continente africano. Entretanto, merece registro espe cial a similaridade encontrada com os distritos alcalinos de Magnet Co ve e Iron Hill, respectivamente situados nos Estados de Arkansas e Colorado dos Estados Unidos da América e de livaara no distrito de Kuusamo na Finlândia.

Mineralògicamente, essas ocorrências guardam per feita identidade com as de Itapirapuã, ressaltando-se a riqueza de $\underline{\text { i }}$ nerais cálcicos, sendo melanita um dos seus constituintes principais, e minerais insaturados, com nefelina e cancrinita em primeiro plano. Um número considerável de variedades petrográficas tem sido reconhecido nesses distritos, formando em geral, dois grandes gru pos: a) o grupo contendo feldspato em sua composição, incluindo os diversos tipos de sienitos, e b) o grupo desprovido dêsse mineral, cor respondendo às rochas alcalinas ultrabásicas (jacupiranguito e outras), às rochas da série dos ijolitos e aos carbonatitos.

Dessas três províncias, sòmente Magnet Cove não tem por encalixante ochar de compósiçãolganítica, estando o ma ciço circundado em tôda sua extensão por rochas sedimentares paleozóicas, mostrando predominância local de folhelho, arenito e novaculi 
to. Processos de fenitização apenas foram observados em Iivaara, tendo levado à formação, em estádios avançados, de sie fiitos insa turados. A analogia com o sucedido em Itapirapuã já foi debatida no sub-capítulo de Fenitização.

Quanto à gênese, pouco se pode dizer sôbre Iivaara, visto que Lehijurvi (1960) em seu trabalho sôbre o distrito não fornece muitos dados a êsse respeito. Já Magnet Cove e Iron Hill fo ram exaustivamente discutidos do ponto de vista genético por Erickson e Blade (1963) e Larsen (1942). Enquanto os primeiros Autores advogaram para o complexo de Magnet Cove uma origem a partir da diferenciação e cristalização fracionada de um magma residual ten * do a composiçãa de um fonolito máfico, que por sua vez se derivou por cristalização fracionada de um magma regional insaturado de composição olivina basalto, êsse último Autor acreditou que o maci ço alcalino de Iron Hill se formou pela reação de um magma basálti co com calcário, seguido de diferenciação magmática do material contaminado resultante. 


\section{CONCLUSŐES}

As conclusões relativas ao estudo geoquímico e pe trológico do maciço alçalino de Itapirapuã são as seguintes:

1. O corpo alcalino, de forma irregular e alongada para NW, ocupa área aproximada de $4 \mathrm{~km}^{2}$ e encontra-se inteiramente encaixado em extensa massa de composição granítica.

2. Calcário metamórfico, pertencente ao Grupo Açun gui, aflora na região e à pequena distância do maciço alcalino.

3. Histogramas de composição mineralógica indicam que feldspatóides, nefelina e seus produtos de alteração, constituem, juntamente com os feldspatos, os principais minerais félsicos das rochas alcalinas, enquanto que os diversos membros da série dos piroxênios (soda--augita, egirina-augita e egirina) formam com a melanita (variedade de granada titanífera) os ferromagnesianos mais im portantes. Como minerais acessórios for am reconhecidos: magnetita, titanita e apatita.

4. A cristalização dos piroxênios, evidenciada a par tir de informações microscópicas e diagramas de variação química, processou-se na seguinte seqtência: soda-augita $\longrightarrow$ egirina-augita $\longrightarrow$ egirina.

5. Do ponto de vista petrográfico, o distrito alcalino é constituído inteiramente de rochas insaturadas, predominando ne felina sienitos sôbre as demais variedades. Melanita-nefelina sieni tos, melanita malignito, biotita melteigito, pulaskito, cancrinita mariupolito e wollastonita-melanita-nefelina sienito, for am também re. conhecidos.

6. Tinguaítos, ocorrendo provàvelmente como pequenos diques, são encontrados no interior e for a do corpo alcalino.

7. Carbonatitos, ocupando aproximadamente as par tes centrais do maciço, estão presentes na forma de pequenos veios irregulares cortando os nefelina sienitos e parecem ter-se formado por substituição seletiva dessa nochas.

8. Uma brecha magmática, mostrando área de expo sição de alguns metros quadrados, aflora na parte sull do maciço. A. composição mineralógica de sua matriz e fragmentos é relativamente simples e corresponde à dos nefelina sienitos e melanita-nefelina sie- 
nitos. Não foram encontrados fragmentos da própria brecha o que leva supor a existência de uma única fase cataclástica.

9. Um corpo de magnetita compacta, tendo em profundidade a forma de uma cornucópia, é encontrado na extremidade sul. do maciço e vem sendo explorado comercialmente. Essa concentração de magnetita, provàvelmente de cristalização tardia, parece ter-se da do por influência de processos de segregação magmática, desconhecen do-se no entanto o mecanismo que levou à sua formação, bem como o seu, modo de "emplacement".

10. As principais características químicas das rochas de Itapirapuã são: a pobreza em sílica e magnésio, a abundância em cálcio, álcalis e voláteis e as concentrações elevadas em V, Nb, Y, Cu e Ba,

11. Os valores obtidos para os índices agpaíticos, juntamente com as feições mineralógicas, constituem as evidências indicativas do caráter "miasquítico" das rochas que compõem o maciço.

12. O índice álcali-cálcico da província de Itapirapuã, obtido a partir do diagrama de Peacock (1931), é de aproximadamente 43,5 , permitindo com isso incluí la dentro da série alcalina dêsse Autor.

13. A análise dos diversos dỉagramas de variação química parece apontar a cristalização fracionada como um dos fa tốres atuantes na formação das rochas alcalinas de Itapirapuã.Os tra çados das diferentes curvas obtidas correspondem em traços gerais aos que deveriam se esperar do processo de cristalização fracionada de um magma de composição basáltica.

14. Processos envolvendo assimilação de calcário e matefial crostal siálico, metassomatose e ação de voláteis parecem tampém ter contribuído para a genêse do maciço de Itapirapuã.

15. Evidểncias mineralógicas e químicas parecem indicar que a rocha encaixante do corpo alcalino foi afetada por pro cessos de fenitização. Contudo, o produto resultante, se bem que mos trando sinais indiscutiveis de ação metassomática, ainda é portador de quartzo em sua composição,

16. Uma rápida análise comparativa aponta Jacupi- 
ranga, Serrote e Anitápolis, dentre as nacionais, e Iron Hill, Magnet Cove e Iivaara, dentre as estrangeiras, como as províncias alcalinas que mais se assemelham mineralógica e petrogrấficamente à de Itapirapuã。 


\section{AGRADECIMENTOS}

O presente trabalho tornou-se possível graças à colaboração prestada pelo Conselho Nacional. de Pesquisas na forma de auxilio para os trabalhos de campo e de laboratório.

Consignamos os melhores agradecimentos aos Profs。 Rui Ribeiro Franco e José Moacyr Vianna Coutinho pela orientação e colabor ação dispensada no transcorrer de nossas pesquisas, bem co mo pelo estímulo e amizade com que sempre nos distinguiram.

Aos químicos Benedito Ferreira Alves, Cláudio Viei ra Dutra, Glória Berenice C.T.C.Brazão da Silva, Raphael Hypolito e Silvia Lourdes Moro somos imensamente gratos pela execução das aná lises químicas de rochas e minerais.

Deixamos também consignados os nossos melhores agradecimentos à Companhila de Cimento Portland Maringá, na pessoa do Dr. Josê Epitácio Passos Guimarães, pelas inúmeras facilidades concedidas no decorrer dos trabalhos de campo.

Ao Prof. Evaristo Ribeiro Filho, do Departamento de Geologia e Paleontologia desta Faculdade, agradecemos a gentileza das fotomicrografias das secções delgadas. Ao Prof. Franco Levi, do mesmo Departamento, o nosso reconhecimento pelas sugestões apresentadas a.o trabalho, no tocante à parte de Geoquímica.

Somos gratos ao colega Marcos Aurélio Farias de Oliveira pelo inestimável auxílio prestado nas várias etapas desta pes quisa.

A Srta. Maria Inês de Paiva a nossa gratidão pela va Liosa ajuda dispensada, seja na revisão do texto, seja no trabalho de datilografia. Ao Sr. José Ponchirolli somos gratos pela elaboração das tabelas constantes desta obra, a execução dos cálculos radiocris talográficos, assim como a sua participação no traballho de datilogra. fia. Ao Sr. José Rufino agradecemos a eficiência e dedicação demonstrada na confeção das diversas figuras que ilustram o presente trabatho.

A todos que, direta ou indiretamente, prestaram sua. colaboração, os nossos melhores agradecimentos. 


\section{BIBLIOGRAFIA}

AHRENS, L.H. (1952) - The use of ionization potentials. Part I: Ionic radii of elements - Geochim, et Cosmoch. Acta, 2, pp.155-169.

ALMEIDA, F.F.M. de (1955) - Geologia e Petrologia do Arquipélago de Fernando de Noronha - Div. Geol. Miner., Mon. XIII, pp. 1-181.

ALMEIDA, F.F.M.de(1961) - Geologia e Petrologia da Ilha de Trindade - Div, Geol. Miner., Mon. XVIII, pp. 1-197.

AMARAL, G. , BUSHEE, J., CORDANI, U.G. , KAWASHITA, K. e REYNOLDS, J.H. (1967) - Potassium-argon ages of alkaline rocks from southern Brazil - Geochim. et Cosmoch. Acta, 31, pp. 117-142.

AOKI, K. (1964) - Clinopyroxenes from alkaline rocks of Japan - Amer. Mineral., 49, pp. 1199-1223.

ASTM (1965) - X-Ray power data file (American Society for Testing Materials).

BAILEY, D. K. e SCHAIRER, J.F. (1966) - The system $\mathrm{Na}_{2} \mathrm{O}-\mathrm{Al}_{2} \mathrm{O}_{3}$ $-\mathrm{Fe}_{2} \mathrm{O}_{3}-\mathrm{SiO}_{2}$ at 1 atmosphere, and the petrogenesis of alkaline rocks - J.Petrol., 7, pp, 114-170.

BARTH, T.F.W. (1962) - Theoretical Petrology - John Wiley and Sons, New York.

BEUS, A. A. (1956) - The geochemistry of beryllium - Geochemistry, 5, pp. $511-531$.

BORISENKO, L.F. (1959) - On the distribution of scandium in igneous rocks from the example of some massifs of the Soviet Union. Geochemistry, 7, pp. 770-777.

BORISENOK, L.A. (1959) - Distribution of gallium in the rocks of the Soviet Union - Geochemistry, 1, pp. 52-70,

BOWEN, N.L. (1928) - The evolution of the igneous rocks - Princeton Univer sity Press, Princeton.

BOWEN, N.L. (1937) - Recent high-temperature research on silicates and its significance in igneous geology - Amer. J.Sci., 33, pp.1-21.

BOWEN, N.L. (1945) - Phase equilibria bearing of the origin and differentiation of alkaline rocks - Amer.J.Sci., 243-A, pp.75-89.

BOWEN, N.L., SCHAIRER, J.F., e POSNJAK, E. (1933) - The system $\mathrm{CaO}-\mathrm{FeO}-\mathrm{SiO}_{2}$ - Amer.J.Sci., 26, pp. 193-284.

BRbGGER, W.C. (1921) - Die Eruptivegesteine des Kristianiagebietes. IV, Das Fengebiet in Telemarken, Norwegen - Vidensk. selsk. skrifter, I. Mat. - naturv. Klasse no 9. Oslo. 
BROWN, G.M. (1957) - Pyroxenes from the early and middle stages of fractionation of the Skaergaard intrusion, East Greenland Min. Mag., 31, pp.511-543.

BROWN, G. M. e VINCENT, E.A. (1963) - Pyroxenes from the late stages of fractionation of the Skaergaard intrusion, East Gre enland - J. Petrol, , 4, pp. 175-197.

BUTLER, J.R. (1954) - The geochemistry and mineralogy of rock weathering (2). The Nordmarka area, Oslo - Geochim. et Cosmoch. Acta, 6, pp. 268-281:

BUTLER, J,R. e SMITH, A.Z. (1962) - Zirconium, niobium and certain other trace elements - Geochim. et Cosmoch. Acta, 26, pp.945-953.

CARMICHAEL, I.S.E. (1962) - Pantelleritic liquids and their phenocrysts - Min. Mag., 33, pp. 86-113.

CARR, M.H. e TUREKIAN, K. K. (1961) - The geochemistry of cobaltGeochim. et Cosmoch. Acta, 23, pp. 9-60.

CHAO, E.C.T. e FLEISCHER, M. (1960) - Abundance of zirconium in igneous rocks - Rep, Int. Geol. Congr. XXI Session (Norden). Part I, pp. 106-131.

CHAYES, F. (1949) - A simple point counter for thin-section analysis Amer. Mineral., 34, pp. 1-11.

DALY, R.A. (1933) - Igneous rocks and the depths of the Earth McGraw-Hill Book Co., Inc., New York.

DEANS, T. (1966) - Economic mineralogy of carbonatite complexes: in Carbonatites (Ed.O.F.Tuttle e J.G.Gittins). Interscience Publishers, London.

DEGENHARDT, H. (1957) - Unter suchungen zur geochemischen Verteilung des Zirkoniums in der Lithosphare - Geochim. et Cosmoch. Acta, 11, pp. 279-309.

DEER, W.A., HOWIE, R. A. e ZUSSMAN, J. (1963) - Rock forming minerals. Vol. I (Ortho- and ring Silicates) e Vol. II (Chain Silicates), Longmans. Vol. IV (Framework Silicates) - John Wiley and Sons, Inc.

ECKERMANN, H. v. (1948) - The alkaline district of Alnd Island Sverig. Geol. Undersbk., Ser.Ca., 36, pp. 1-176.

ECKERMANN, H.v. (1952) - The distribution of barium and strontium in the rocks and minerals of the syenite and alkaline rocks of Alnd Island - Arkiv Mineral. Geol., 13, pp.367-375.

EDGAR, A. D. (1965) - The mineralogical composition of some nepheline alteration products - Amer. Mineral, , 50, pp.978-989. 
ERTCKSON, R。I. e BLADE, L.V. (1963) - Geochemistry and petrology of the Alkalic Igneous Complex at Magnet Cove, Arkansas - U.S. Geol. Surv., Prof. Paper, 425, pp.1-93.

FREITAS, R.O.de (1947) - Geologia e Petrologia da Ilha de São Sebas tiäo - Fac.Fì..Ci.Let, 85, Geologia no3, pp. 1-244.

GERASIMOVSKII, V.I. (1956) - Geochemistry and mineralogy of nephe line syenite intrusions - Geochemistry, 5, pp.494-510。

GERASIMOVSKII, V.I. e BELYAYEV, Y.I. (1963a) - Chromium, nickel, vanadium and copper content of alkalic rocks, Kola Peninsula Geochemistry, 1, pp. 22-34.

GERASIMOVSKII, V.I. e BELYAYEV, Y.I. (1963b) - Manganese, barium and strontium in the alkalic rocks of the Kola Peninsula - Geochem istry, 12, pp. 1161-1174.

GERASIMOVSKII, V。I。 e LEBEDEV, V.I. (1958) - Proportions of strontium and calcium in rocks of the Lovozero massif. - Geochemistry, 6, pp.699-705.

GERASTMOVSKT, V.I. e NESMEYANOVA, L.I. (1960) - Lead and zinc distribution in the rocks of the Lovozero, massif-Geochemistry, 7, pp.704--708.

GOLD, D.P. (1966) - The average and typical chemical composition of carbonatites - Ind.Mineral. (no prelo).

GOLDSCHMIDT, V.M. (1954) - Geochemistry - (Ed.A.Muir)。 Oxford University Press。

GOLDSCHMIDT, V.M. e PETERS, C.L.(1931) - Zur Geochemie des Galliums - Nachr。Ges。Wiss,, Gobttingen, Math。 Phys。Kl。, fachgruppe IV, pp。165-183.

GOMES, C.B. e CORDANI, U。G。 (1965) - Geocronología do maciço alca Lino de Itapirapuã, SP, Brasil - An.Acad,Bras.Ci., 37, pp-497-501。

GOMES, C.B., DUTRA, C.V。, HYPOLITO, R。 e VALARELLI, J.V。 - As granadas titanifer as das rochas alcalinas de Itapirapuã, SP, Brasil(em preparação).

GORDON, M.Jr。 e MURATA, K.J. (1952) - Minor elements in Arkansas bauxite - Econ. Geol., 47, pp.169-179.

GORDY, W。 e THOMAS, W.J.O. (1956) - Electronegativities of the elements - J.Chem. Phys., 24, pp.439-444.

GUIMARÃES, D。 e DUTRA, C.V. (1962) - Contribuição à geoquímica das xochas alcalinas do Brasil-Div. Fom. Prod.Mineral, 112, pp.47-70.

HEIER, K.S。(1964) - Geochemistry of the nepheline syenite on Stjern $\phi y$, North Norway - Norsk Geol.Tidsskr.,44, pp.205-215.

HEIER, K.S。 e TAYLOR, S.R. (1964) - A note on the geochemistry of alkaline rocks - Norsk Geol. Tidsskr。, 44, pp.197-204. 
HEINRICH, E。Wm。(1965) - Microscopic identification of minerals McGraw Hill Book Co., New York.

HESS, H.H. (1949) - Chemical composition and optical properties of common clinopyroxenes, Part I - Amer. Mineral., 34, pp.621-666.

HEWITT, D.F。(1960) - Nepheline syenite deposits of Southern Ontario - Ontario Dept. Mines, 69, p.169.

HJGAZY, R.A. (1954) - Trace elements of volcanic and ultrabasic potas sic rocks of southwestern Uganda and adjoining parts of the Belgian Congo - Bull. Geol. Soc. Amer., 65, pp.39-70.

HOLMES, A。(1920) - Petrographic methods and calculations - Thomas Murby and Co., London.

HOLMES, A。(1950) - Petrogenesis of katungite and its associates Amer。Mineral., 35, pp.772-792。

HYT ONEN, K。 (1959)-On the petrology and mineralogy of some alkaline volcanic rocks of Toror Hills, Mt. Moroto, and Morulinga, north-easthern Uganda - Bull.Comm.Géol. Finlande; 184, pp.75-132.

JOHANNSEN, A. (1938 e 1939)-A descriptive petrography of the igneous rocks.Vol.I(2a.edição)e Vol.IV-University Chicago Press, Chicago.

KENNEDY, G.C.(1947)-Charts for correlation of optical properties with chemical composition of some common rock-forming minerals Amer.Mineral., 32, pp.561-573.

KING, B.C. (1949) - The Napak area of Southern Karamoja, Uganda Uganda geol. Surv。 Mem., 5 .

KING, B.C. (1965) - Petrogenesis of the Alkaline Igneous Rock Suites of the Volcanic and Intrusive Centres of Eastern Uganda - J.Petrol., 6. pp. 67-100。

KING, B。C。 e SUTHERLAND, D.S。(1960) - Alkaline rocks of Eastern and Southern Africa - Science Progress, 48, pp.709-720.

KTNG, B。C。 e SUTHERLAND, D。S。(1966) - The carbonatites complexes of Eastern Uganda: in Carbonatites - (Ed.O.F.Tuttle e J.G.Gittins). Interscience Publishers, London.

KUKHARENKO, A.A。 DONTSOVA, E.I.(1964)-A contribution to the prob lem of the genesis of carbonatites- Econ. GeoL.USSR, 1, pp.47-68.

KULP.J.I. (1961) - Geologic time scale - Science, 133, pp.1105-1114.

KURODA, P.K. e SANDELL, E.B. (1954) - Geochemistry of molybdenum - Geochim. et Cosmoch. Acta, 6, pp.35-63.

KUSHIRO, I. (1959) - Preliminary note on alkali-dolerite of Atumi district, northern Japan - Japanese J.Geol.Geogr。, 30, pp.259-272.

KUSHIRO, I. (1960) - Si-Al relations in clinopyroxenes from igneous rocks - Amer. J.Sci., 258, pp。548-554.

I.A TOUCHE, T.H.D. (1908) - A specific gravity balance for large rock specimens - Nature, 77, p.221. 
LARSEN, E.S. (1942) - Alkalic rocks of Iron Hill, Gunnison County, Colorado - U.S.Geol. Surv,, Prof. Paper, 197-A, pp.1-64.

LE BAS, M.J. (1962) - The role of aluminium in igneous clinopyroxenes with relation to their parentage - Amer.J.Sci., 260, pp.267-288.

LEHIJÁRVI, M.(1960) - The alkaline district of Tivaara, Kuusamo, Finland - Bull. Comm. Géol. Finland, 185, pp.1-62,

LEINZ, V.(1940) - Petrologia das jazidas de apatita de Ipanema - Div。 Fom. Prod. Mineral, 40, pp. 1 - 52 .

MACDONALD, G。A. (1949) - Hawaiian petrographic province - Bull. Geo1.Soc.Amer。, 60, pp. 1541-1596.

MCKENZIE, W.S. e SMITH, J.V。(1955) - The alkali feldspars: I Orthoclase microperthites - Amer. Mineral., 40, pp.707-732.

McKJE, D. (1966) - Fenitization: in Carbonatites - (Ed。O.F.Tuttle e J.G.Gittins). Interscience Publishers, London.

MELCHER, G.C. (1954) - Nota sôbre o distrito alcalino de Jacupiranga, Estado de São Paulo - Div. Geol. Miner., Notas Preliminares e Estudos, 84, pp. 1-20.

MELCHER, G.C. e JOHNSON, R.F.(1957) - Geologia e depósitos mine rais do vale do rio Ribeira de Iguape-Div。Fom. Prod.Mineral. (inédito).

MELCHER, G.C. e COUTINHO, J.M.V. (1966) - Rochas alcalinas e carbonatito de Anitápolis, Estado de Santa Catarina - Soc. Bras. Geol., 15, pp.59-93.

MELFI, A.J., BITTENCOURT, I॰ e CORDANI, U.G. (1965) - Reconhecimento fotogeológico de parte do grupo Açungui - Bragantia, 24, pp. $447-474$.

MOORE, C。E.(1958) - Atomic Energy Levels - U.S.Nat.Bur.Standards Circ。 467 , vol. 3.

MORAES REGO, L.F.de (1933) - Contribuição ao estudo das formações prédevoneanas de São Paulo - Inst.Agron. Geogr. São Paulo, pp. $1-43$.

NOCKOLDS, S.R. (1954) - Average chemical composition of some igneous rocks - Bull. Geol.soc.Amer., 65, pp.1007-1.032.

NOCKOLDS, S.R.e ALLEN, R。 (1.953) - The geochemistry of some igneous rock series. Part I - Geochim. et Cosmoch.Acta, 4, pp. 105-142.

NOCKOLDS, S.R。 e ALLEN, R。(1954) - The geochemistry of some igneous rock series. Part II - Geochim. et Cosmoch. Acta, 5, pp.245-285. 
NOCKOLDS, S。R。e MITCHELL, R。L.(1948) - The geochemistry of some Caledonian plutonic rocks: A study in relationship between the major and trace elements of igneous rocks and their minerals Trans.Roy.Soc。Edinburgh, 61, pp.533-575.

OFTEDAL, I. (1943) - Scandium in biotite as a geologic thermometer - Norsk Geol. Tidsskr。, 23, p.202.

OLSON, J。C., SHAWE, D.R。, PRAY, L。C., SHARP, W。N。 EHEWETT, D。F。 (1954)-Rare earth mineral deposits of the Mountain Pass District, San Bernardino County, California-U.S.Geol.Surv。, Prof.Paper, 261.

PARK, C.F.Jr。e MacDIARMID, R.A. (1964) - Ore Deposits - W.H. Freeman and Company, San Francisco.

PASSOS GUIMARÃES, J.E. (1960) - Relatório sôbre a jazida de magnetita de Itapirapuã, Município de Ribeira - (inédito).

PEACOCK, M。A. (1931) - Classification of igneous rock series - J. Geolo 39, pp. 54-57.

PECORA, W.T. (1956) - Carbonatites: A review - Bull.Geol.Soc.Amer。, $67,1537-1556$ 。

PENALVA, F。(1962) - Brecha magmática do Itatiaia - Soc.Bras.Geol., 11, $p$. $117-122$.

RINGWOOD, A.E。(1955a) - The principles governing trace element distribution during magmatic crystallization. Part I: The influence of eletronegativity - Geochim。 et Cosmoch. Acta, 7, pp. 189-202.

RINGWOOD, A.E。(1955b) - The principles governing trace element behaviour during magmatic cristallization. Part II: The role of complex formation - Geochim. et Cosmoch.Acta., 7, pp. 242-254.

SAETHER, E。(1957) - The alkaline rock province of the Fen area in southern Norway - Det. Kgl. Nor ske.Vid.Selsk.Skr。, n? 1.

SANDELL, E。B。(1952) - The beryllium content of igneous rocks Ceochim. et Cosmoch. Acta, 2, pp.211-216.

SANDELL, E。B。 e GOLDICH, S。S。 (1943) - The rarer metallic consti tuents of some American igneous rocks - J.Geo1., 51, pp.99-115 e 167-189.

SCHAIRER, J。F。(1950) - The alkali-feldspar join in the system $\mathrm{NaAlSiO}_{4}$ KAlSiO $_{4}: \mathrm{SiO}_{2}-\mathrm{J}_{\circ} \mathrm{Geol}, 58$, pp.512-517.

SEMENOV, E.T. (1958) - Relationship between composition of rare earths and composition and structures of minerals - Geochemistry, 5, pp。 574-586.

SHAND, S. J. (1943) - Eruptive Rocks - Thomas Murby, London (2a. edição).

SHAND, S.J. (1945) - The present status of Daly's hypothesis of the alkaline rocks - Amer。J.Sci., 243-A, pp。495-507. 
SHAW, D.M. (1957) - The geochemistry of gallium, indium and thal lium: a review - Physics and Chemistry of the Earth, 2, pp. 164211. Pergamon Press.

SHAW, D.M. (1964) - Interprétation géochi mique des éléments en tra*. ces dans les roches cristallines - Masson et Cie., Paris.

SIEDNER, G。(1965) - Geochemical features of a strongly fractionated alkali igneous suite - Geochim. et Cosmoch. Acta, 29, pp.113-137.

SIMPSON, E.S.W. (1954) - On the graphical representation of dif ferentiation trends in igneous rocks - Geol. Mag., 91, pp. 238-244.

SфRENSEN, H. (1960) - On the agpaitic rocks - Rep. Int. Geol.Congr. XXI Session (Norden). Part XIII, pp.319-327.

TAYLOR, S.R。(1.966) - The application of trace element data to problems in petrology - Physics and Chemistry of the Earth, 6, pp, 133-213. Pergamon Press.

TEMPLE, A. K. e GROGAN, R.M. (1965) - Carbonatite and related alkalic rocks at Powderhorn, Colorado - Econ. Geol., 60, pp.672692.

TILLEY, C.E. (1958) - Problems of alkali rock genesis - Quart. J. Geol. Lond., 113, pp. 323-357.

TROGER, W.E。(1956) - Optische Bestimmung der ge steinsbildenden Minerale - E.Schweizerbart'sche Verlagsbuchhandlung, Stuttgart (2a. edição).

TUREKIAN, K. K。 e KULP, J.L。 (1956) - The geochemistry of Strontium - Geochim. et Cosmoch.Acta, 10, pp.245-296.

TUREKIAN, K. K。 e WEDEPOHL, K.H. (1961) - Distribution of the elements in some major units of the Earth's crust - Bull. Geol. Soc. Amer。, 72, pp. 175-1.92.

TURNER, F。J。(1942) - Determination of extinction angles in monoclinic pyroxenes and amphiboles - Amer.J.Sci., 240, pp.571-583.

TURNER, F.J。 e VERHOOGEN, J。 (1960) - Igneous and metamorphic petrology - McGraw Hill Book Co., New York (2a. edição).

TUTTLE, O.F. (1952) - Optical studies on alkali feldspars - Amer。J. Sci., Bowen vol., pp.553-567.

UPTON, B. G. (1960) - The alkaline igneous complex of Kûngnât Fjeld, South Greenland - Medd. om Gronland, 123, pp.5-141.

USSING, N。V. (1911) - Geology of country around Julianehaab, Greenland - Medd. om Grónland, 38, p.376.

VERWOERD, W.J. (1966) - South African carbonatites and their probable mode of origin - Ann. Univ.Stellenbosch, 41, ser.A (2), pp. $1-233$. 
VINOGRADOV, A.P., VAINSHTEIN, E。E。 e PAVLENKO, L.I. (1958) - Tungsten and molybdenum in igneous rocks (as related to the geochemistry of tungsten) - Geochemistry, 5, pp.497-509.

VI.ASOV, K.A. KUZ'MENKO, M.Z。 e ES'KOVA, E。M. (1966) - The Lovozero alkali massif - Hafner Publishing Company, N ew York.

VOGT, J。H. Is。 (1924) - Nickel in igneous rocks - Econ, Geol., 18, pp. $307-353$.

WAGER, L。R。 e MITCHELL, R。L。(1951) - The distribution of trace elements during strong fractionation of basic magma:A further study of the Skaergaard intrusion, East Greenland - Geochim。 et Cosmoch.Acta, 1, pp.129-208.

WAMBEKE, L $\iota_{0} v_{0}(1964)$ - La géochimie des roches du Kaiserstuhl. EURATOM publication. EUR, 1827, d, f, e, pp.93-192.

WARNE, S.St. (1962) - A quick field or laboratory staining scheme for the differentiation of the major carbonate minerals - J.Sed. Petrol., 32, pp.29-38.

WICKMAN, F。E. (1943) - Some aspects of the geochemistry of igneous rocks and of crystallization by differentiation - Geol. F\&ren. Stockholm Forh。, 65, pp.371-396.

WILKINSON, J。F.G。(1957) - The clinopyroxenes of a differentiated teschenite sill, near Gunnedah, New South Wales - Geol. Mag., 94, pp. $123-134$.

WILLIAMS, C.E॰ (1959) - The origin of carbonatites and related alkaline rocks - Rec.geol.Surv。Uganda 1955-1956, pp.9-31.

WLLLIAMS, H. TURNER, F.J. e GILBERT, C.M. (1954) Petrography: An introduction to the study of rocks in thin section - W. H. Freeman and Co., San Francisco.

YACI, K。 (1953) - Petrochemical studies on the alkalic rocks of the Morotu district, Sakhalin - Bul1.Geol. Soc. Amer., 64, pp.769-810.

YAGI, K。 (1958) - Synthetic pyroxenes of acmite-diopside system. - J.Min.Soc.Japan, 3, pp.763-769.

YAGI, K. (1962) - A reconnaissance of the systems acmite-diopside and acmite-nepheline - Carnegie Inst. Washington, Year Book 61, pp. 98-99.

YAGI, Ko (1966) - The system acmite-diopside and its bearing on the stability relations of the acmite-hedenbergite-diopside system - Amer. Mineral., 51, pp.976-1000.

YEREMENKO, G。K。, WALTER, A。A。 E KLIMENCHUK, V。I. (1963)

- On the distribution of gallium in alkalic rocks, Azov Region

- Geochemistry, 2, pp.145-150。 
ZEDLATZ, O。 (1933) - 故er titanreichen Kalkeisengranat - Zentrabl. Min。, A, pp. 225-237.

ZEDLTZ, O。 (1935) - Utber titanhaltige Kalkeisengranat II Sentrabl。Min。, A, pp.68.78.

ZLOBIN, B.I. e GORSHKOVA, M.S. (1964) - Luead and zinc in alkalic rocks and their bearing on some petrological problems -

Geochemistry, 4, pp.317-328. 


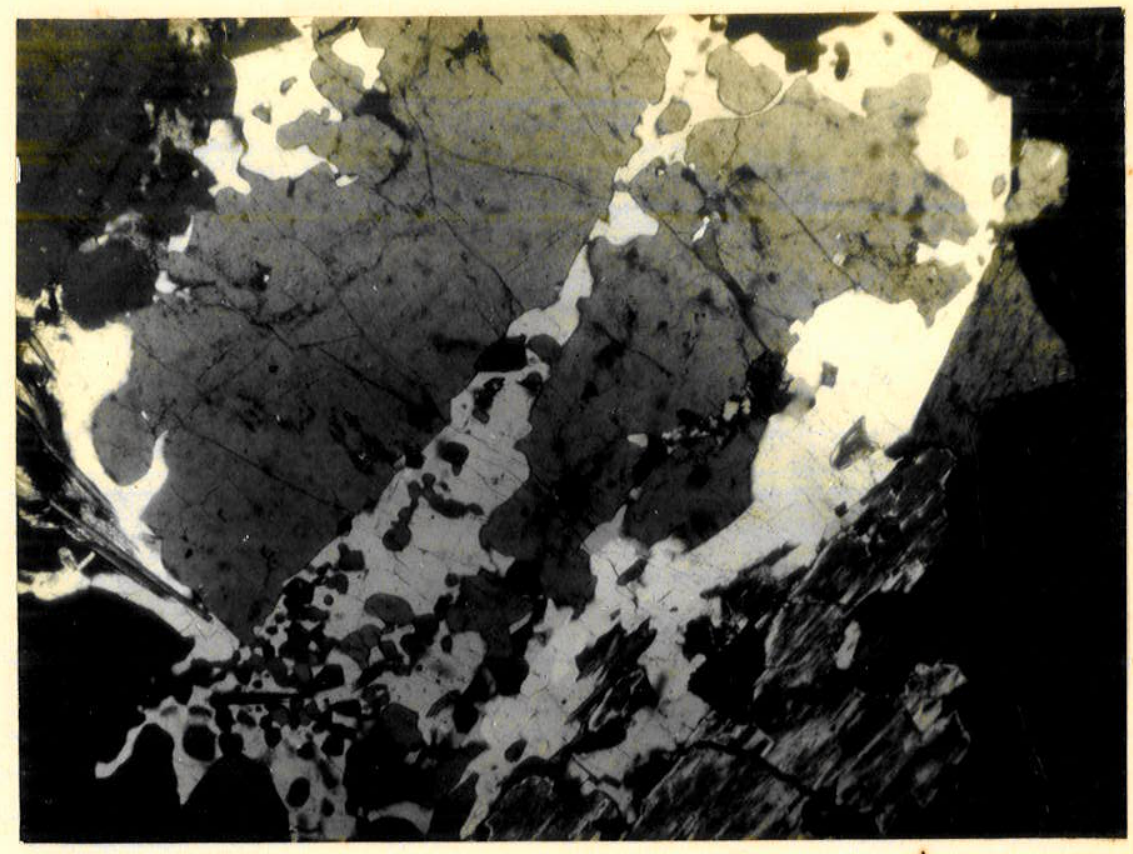

Fotomicrografia 3 - Cancrinita(branca)formando-se a s ex pensas de nefelina(cinza). Cristal grande de egirina-augita, mostrando clivagem, na parte inferior da foto, lado di.reito. Nícois cruzados. Aumento:40 X.

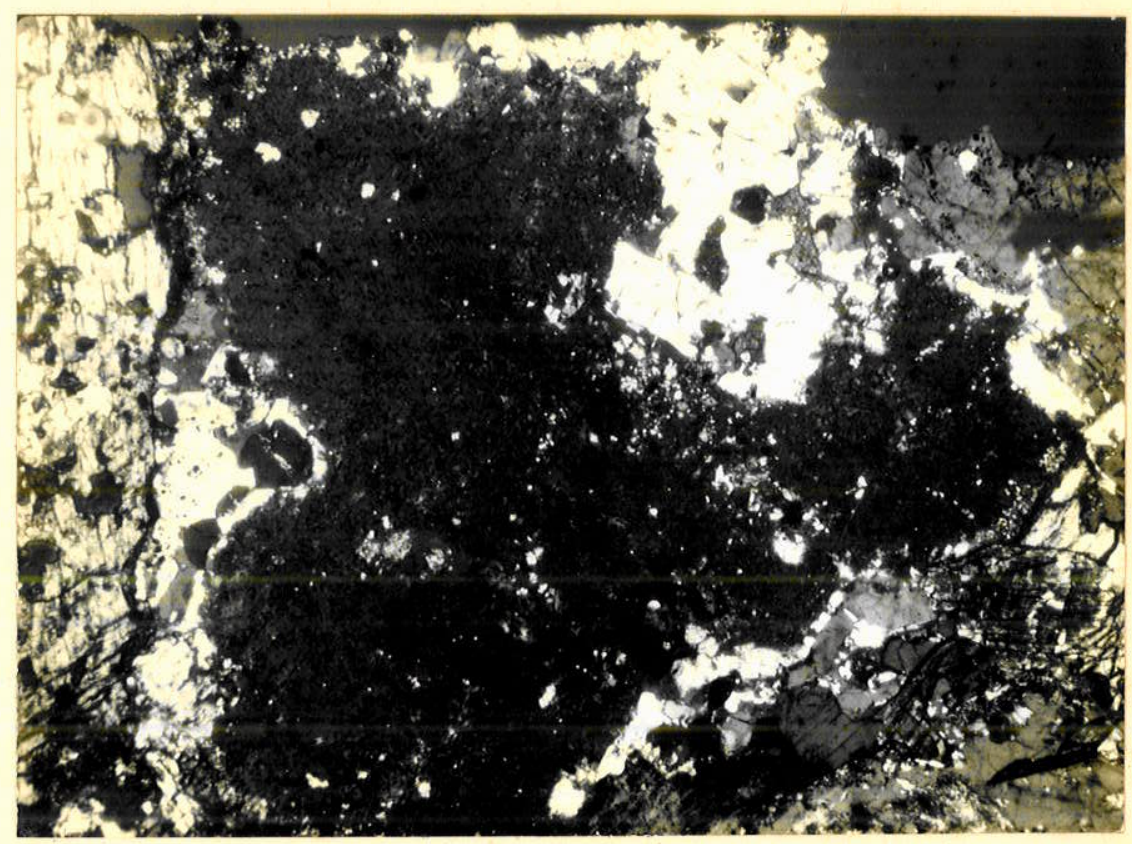

Fotomicrografia 2 - Agregado mineralógico semi-isotrópico(cinza escuro)resultante da alteração de nefelina. No seu interior vêtn-se pontos claros correspondentes à can crinita e calcita (maiorrelêvo) $\mathrm{Nas}$ bordas do agregado, ain da aparecem remanescentes(branca)do antigo cristal de nefelina, bem como cancrinita(alguns pontos cinzentos) e calcita (grânulos de maior relêvo). Nícois sub-paralelos. Aumento: $40 \mathrm{X}$. 


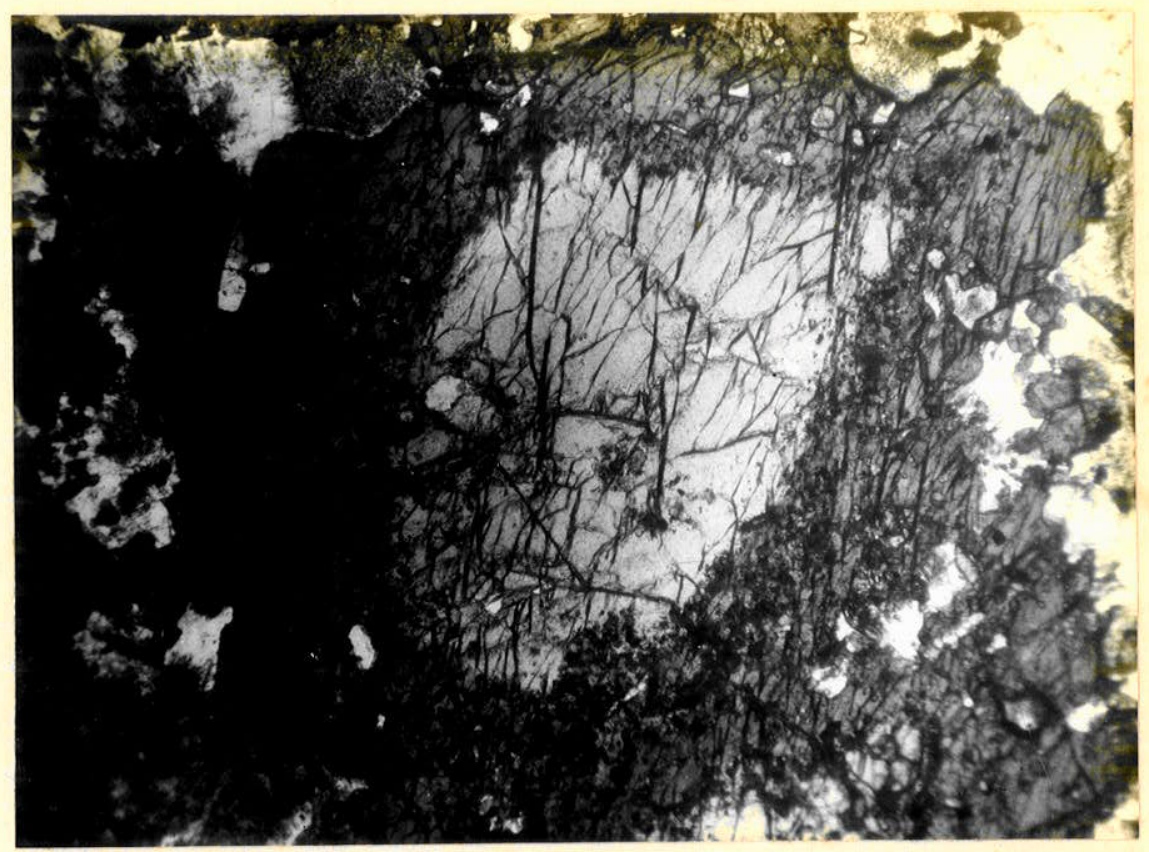

Fotomicrografia 3 - Cristal de piroxênio mostrando estru tura zonada. As partes centrais(cinza claro)correspondem à variedade soda-augita, enquanto que as bordas são de egi rina-augita. Nícois paralelos. Aumento: $20 \mathrm{X}$.

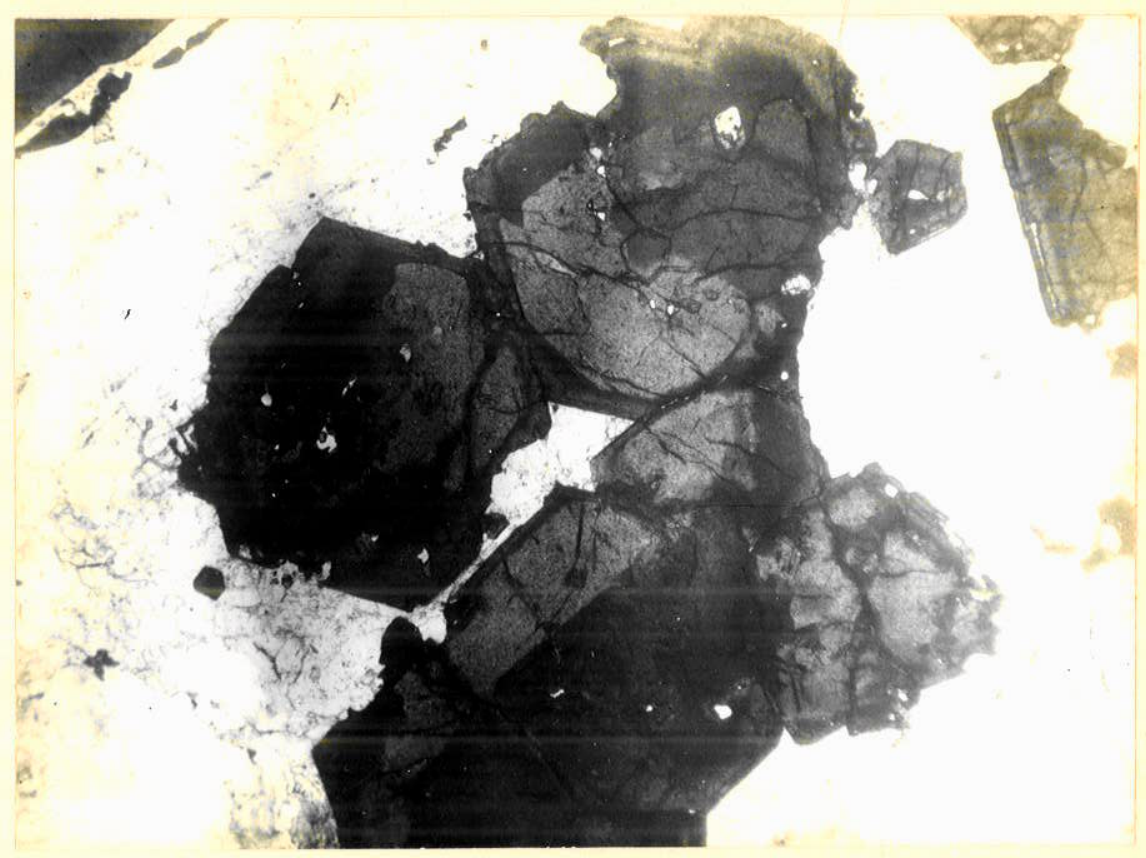

Fotomicrografia 4 - Cristais idiomórficos de granada mos trando estrutura zonada. Área branca, sem relêvo, é composta de nefelina e feldspato alcalino. Nícois paralelos. Au mento: $22,5 \mathrm{X}$. 


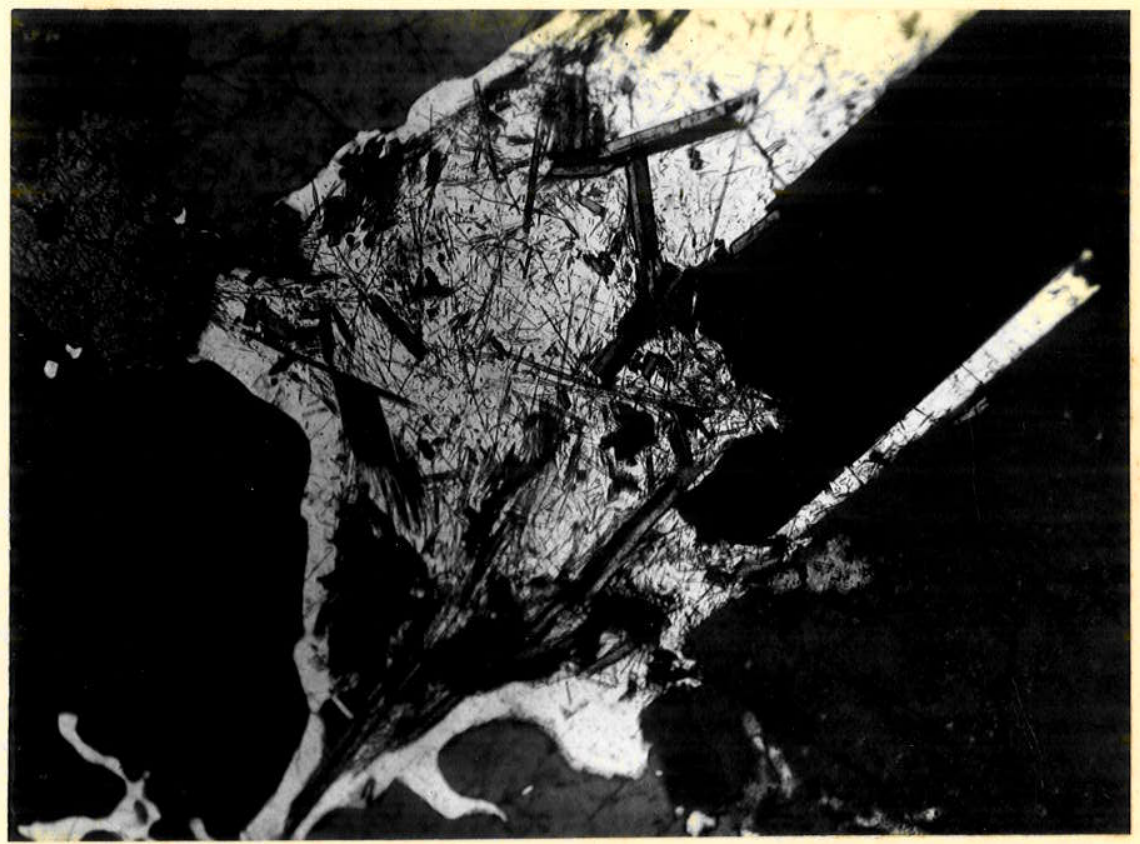

Fotomicrografia 5 - Mineral A, mostrando hábito alongado e geminação, imerso em cristais de cancrinita.(branca). Lado esquerdo, parte inferior da foto, vê-se cancrinita(bran ca) formando-se a partir de nefelina(cinza médio e escurot) A direita da foto, cristais de feldspato alcalino(cinza)exibin do contornos regulares e, à esquerda, lado superior, cristais de egirina-augita. Nícois cruzados.Aumento: 50 X.

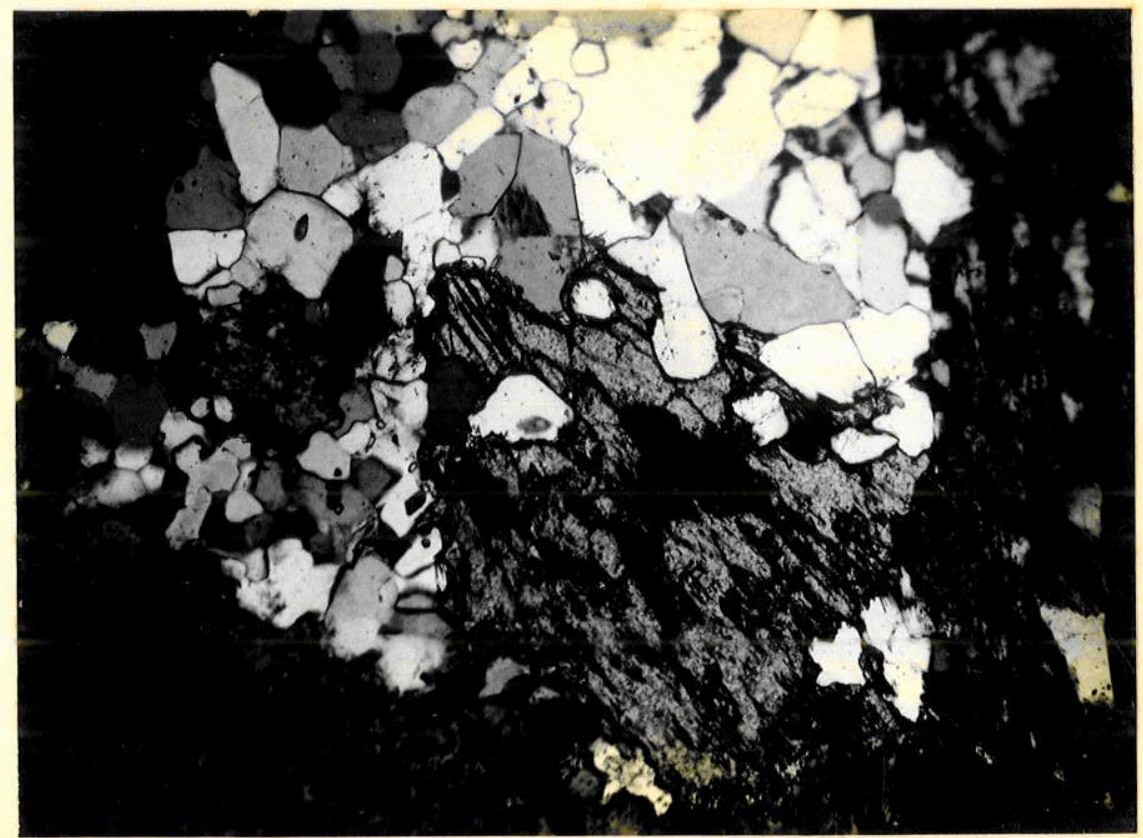

Fotomicrografia 6 - Mineral. B.Cristal único mostrando clivagem e relêvo alto e em associação com grânulos de cancrinita(agregado branco a cinza, ocupando as partes centrais da foto)e feldspato alcalino(cinza escuro, cristais parcialmente alterados e distribuídos ao longo das partes marginais da foto). No interior do cristal do minera! $\mathrm{B}$, vê- se mancha escura constituída de biotita. Ní. o coss cruzados. Aumento: $75 \mathrm{X}$. 


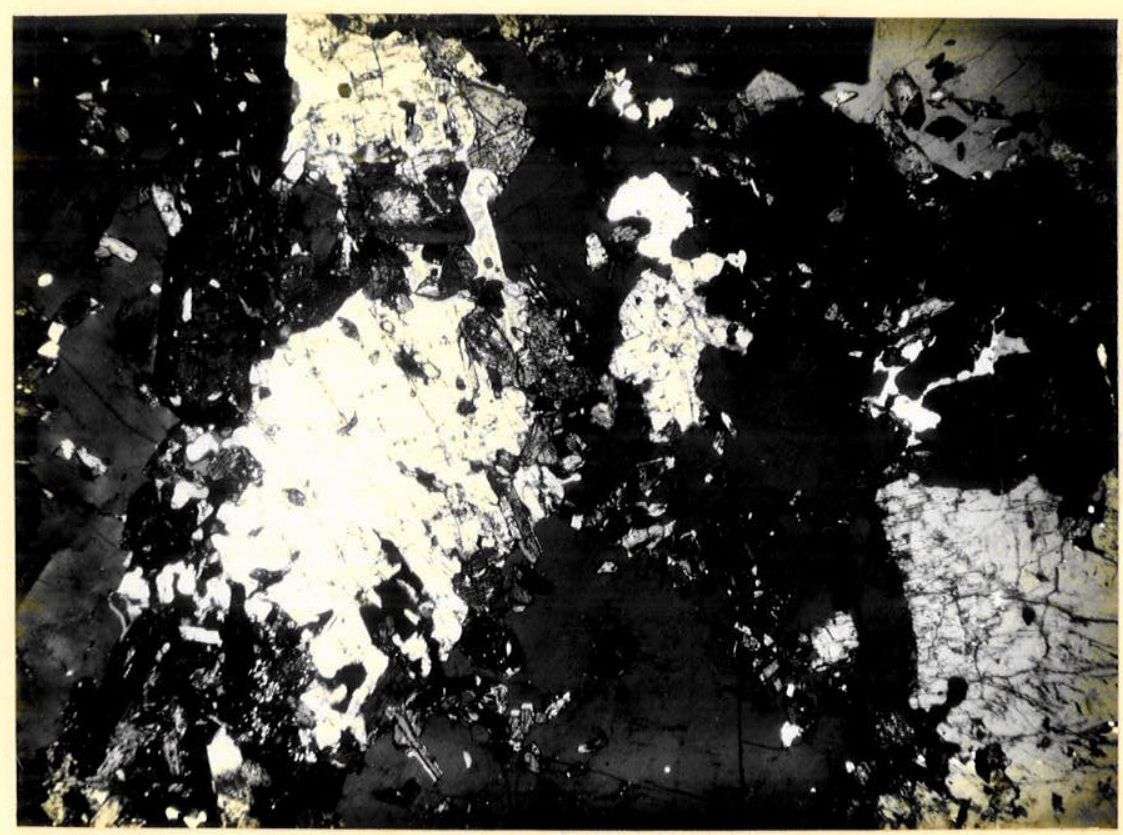

Fotomicrografia 7 - Nefelina sienito.Cristais de nef́lina (branca a cinza claro)e cancrinita(formas irregulares esbranquiçadas)em associação com feldspato alcalino(cinza médio a escuro).Vêem-se também cristais zonados de egi rina-augita e de titanita(minerais idiomórficos de relêvo alto). Nícois cruzados. Aumento: $20 \mathrm{X}$.

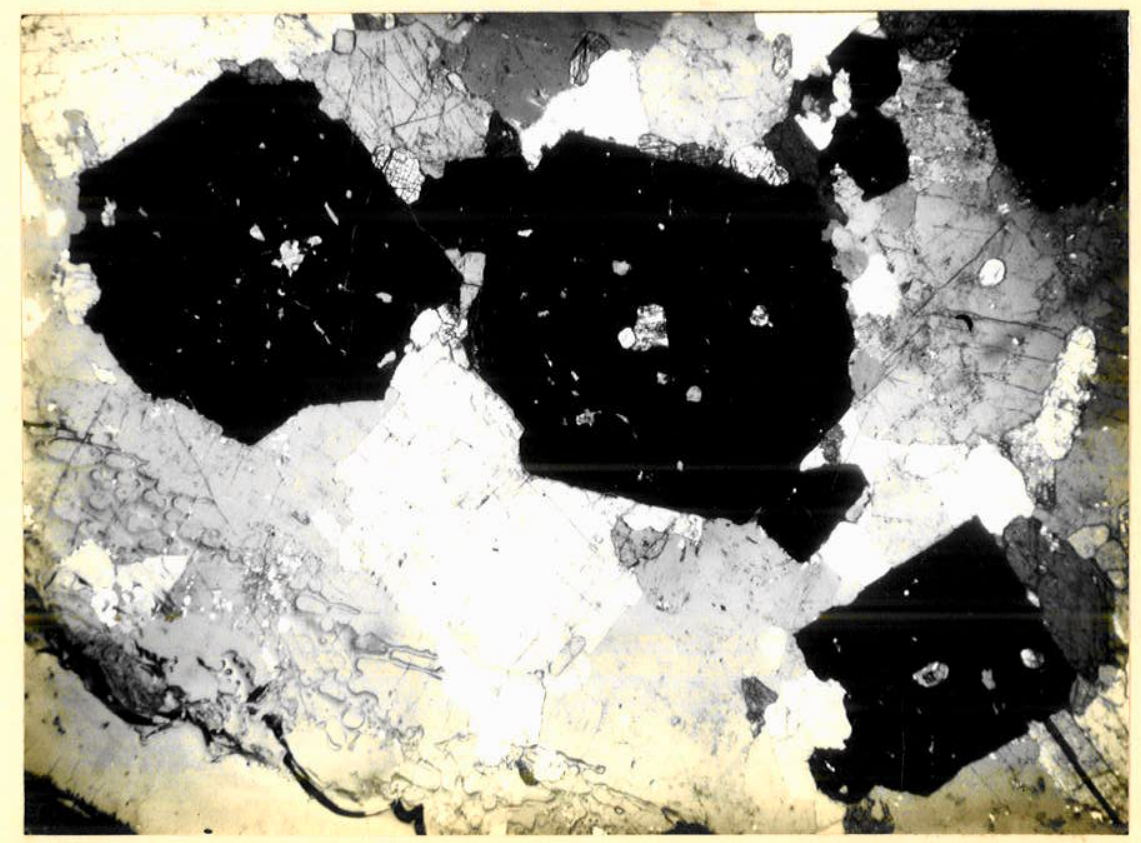

Fotomicrografia 8 - Cristais idiomórficos de granada mostrando estrutura poiquilítica. As inclusões são de ne-r felina e egirina-augita. A lado veem-se cristais de nefelina, feldspato alcalino e egirina-augita. Nícois sub-paralelos. Aumento: $20 \mathrm{X}$. 


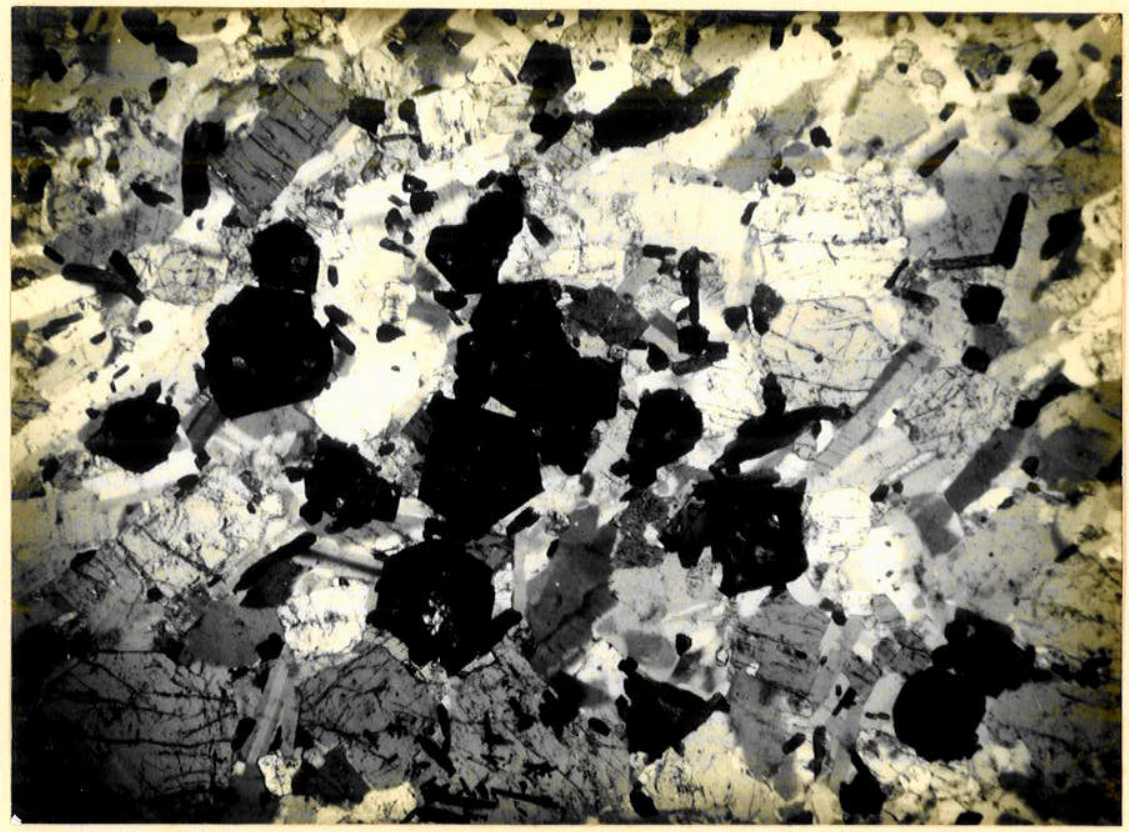

Fotomicrografia 9 - Melanita-nefelina sienito. Cristais idiomórficos de melanita associados à nefelina(branca a cinza médio) e feldspato alcalino ripiforme. Ao lado do hábito, a nefelina se distingue também do feldspato pelo maior grau de alteração ao longo de fraturas e clivagens. Nícois sub-paralelos. Aumento: $20 \mathrm{X}$.

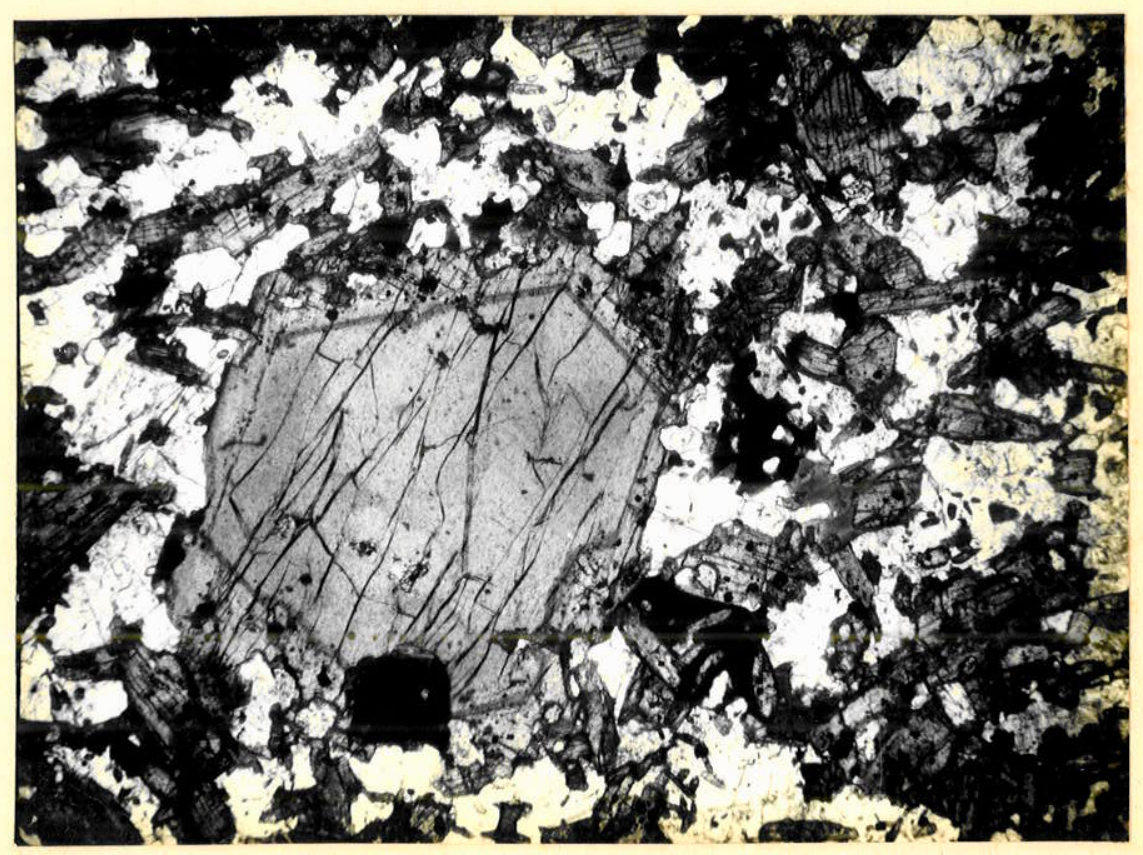

Fotomicrografia 10 - Biotita melteigito. Fenocristal zonado de soda-augita imer so em matriz constituída de so da-augita, nefelina e cancrinita (branca) e titanita (mine rais idiomórficos de relêvo alto). Nícois paralelos. Aumento: $20 \mathrm{X}$. 


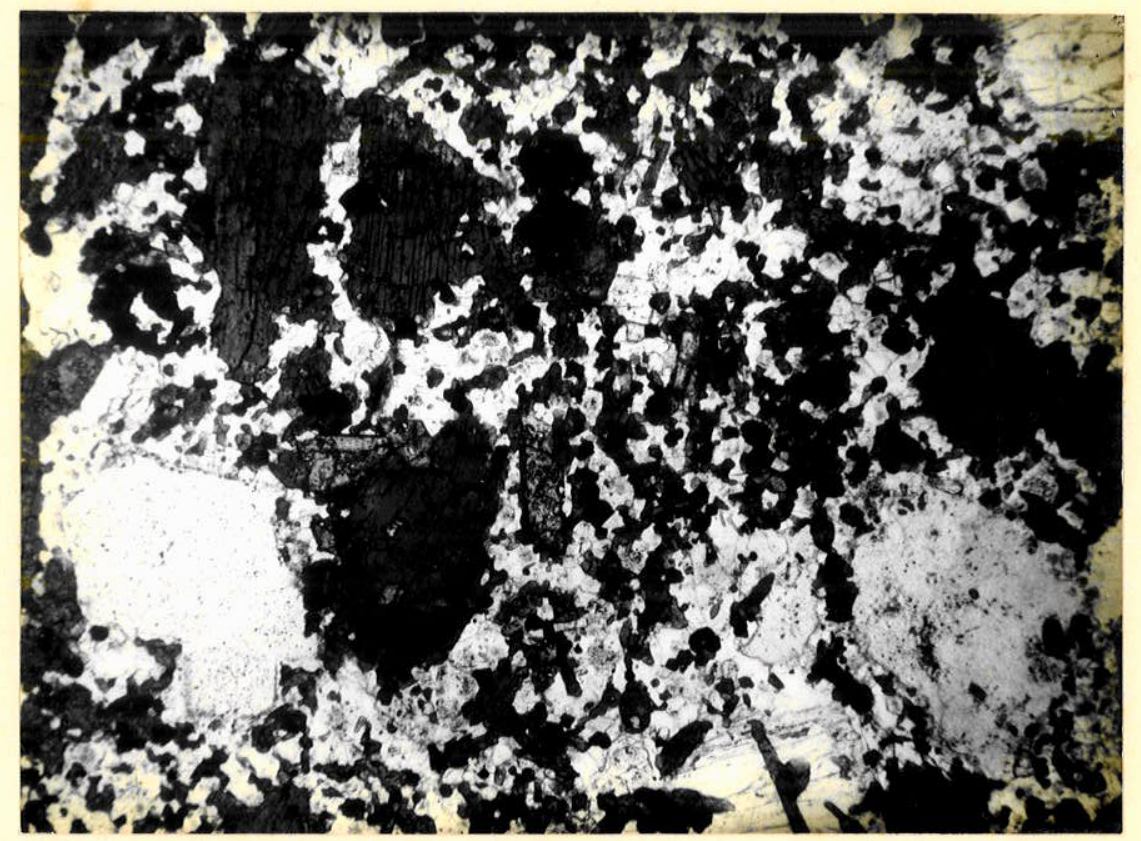

Fotomicrografia 11 - Melanita malignito. Cristais de melanita(grânulos pretos aproximadamente equidimensionais) e egirina-augita(cinza médio a escuro)em associação com nefelina(branca)e titanita idiomórfica(contôrno losangular e relêvo alto). Nícois paralelos. Aumento: $20 \mathrm{X}$.

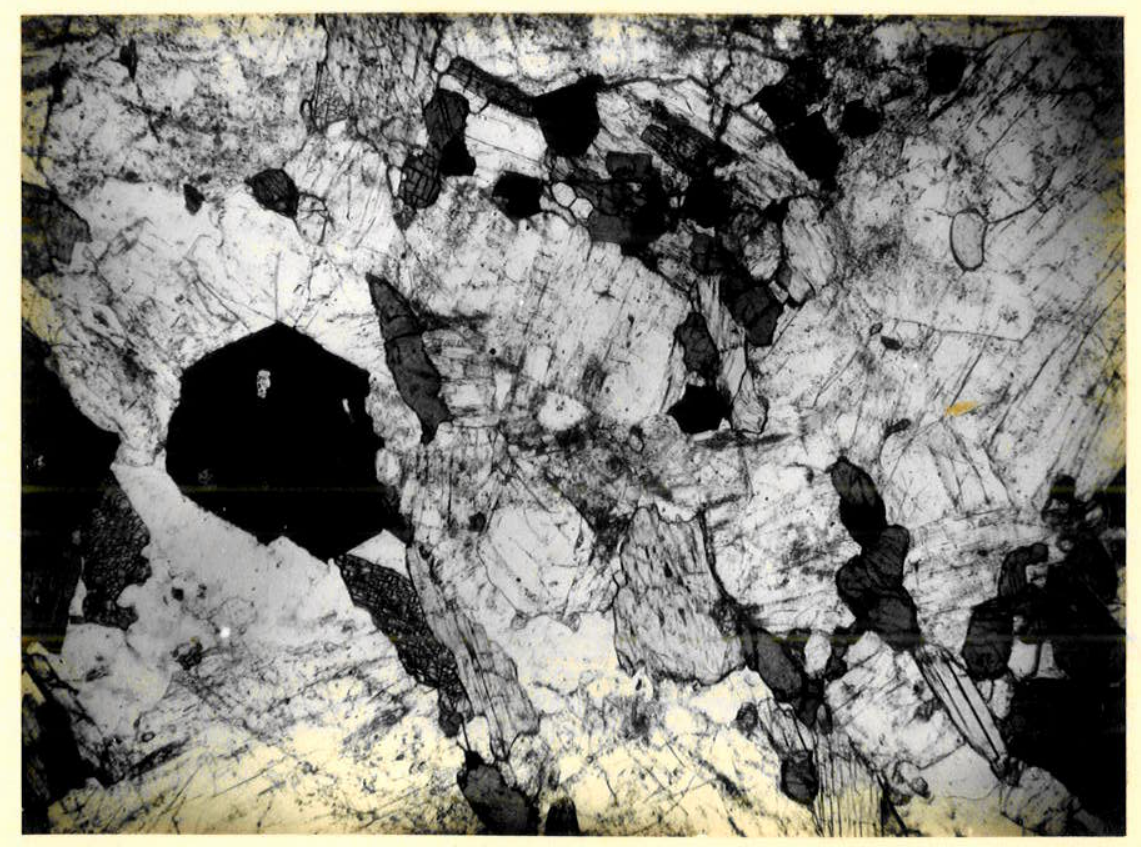

Fotomicrografia 12 - Wollastonita-melanita-nefelina sienito. Cristais idiomórficos de melanita(preta)associados à egirina-augita(cinza médio a escuro) e wollastonita(cinza claro, clivagem paralela ao alongamento e relêvo médio). O restante da rocha (cinza esbranquiçado) é constituído de nefelina e, em menor quantidade, de feldspato alcalino. Nícois paralelos. Aumento: $20 \mathrm{X}$. 


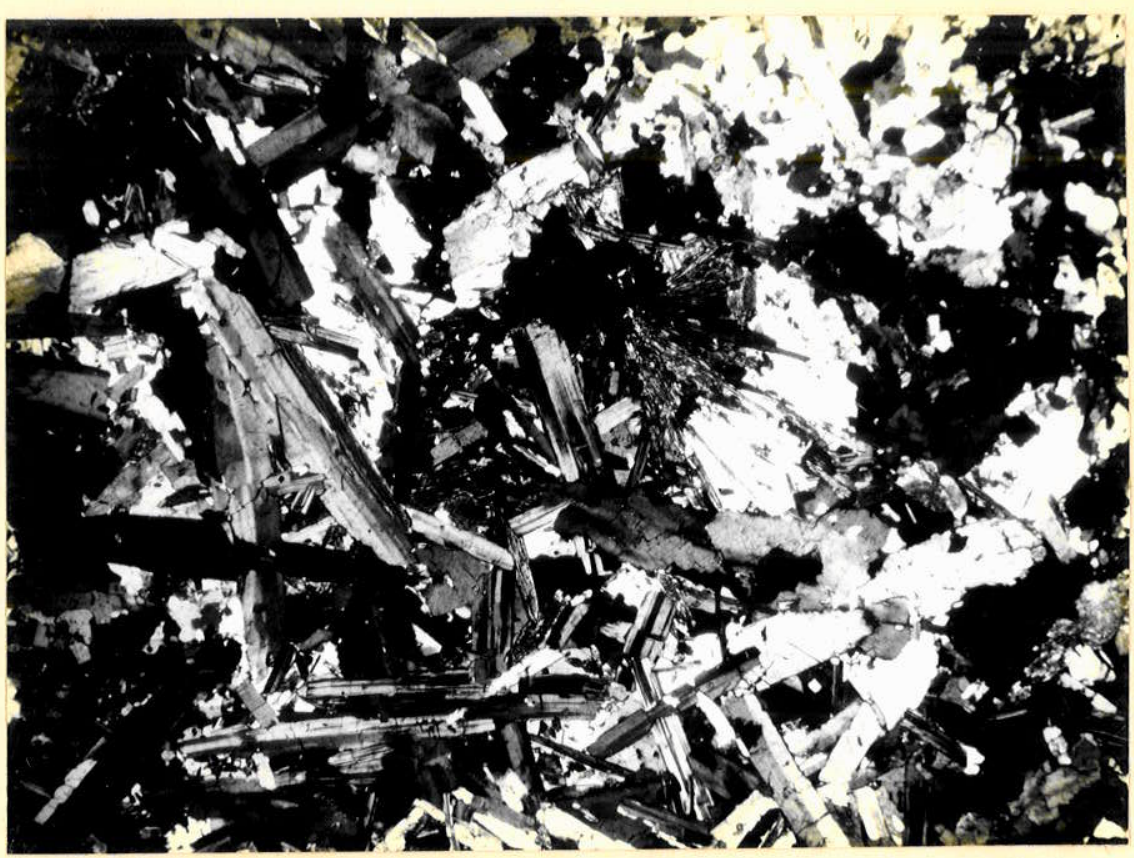

Fotomicrografia 13 - Cancrinita mariupolito. Albita, de hábito ripiforme e comumente geminada(branca a cinza escuro) em associação com egirina(agregado fibrorradial. ocupando aproximadamente as partes centrais da foto) e cancrinita(mineral xenomórfico de côr branca). Nícois cru zados. Aumento: $20 \mathrm{X}$.

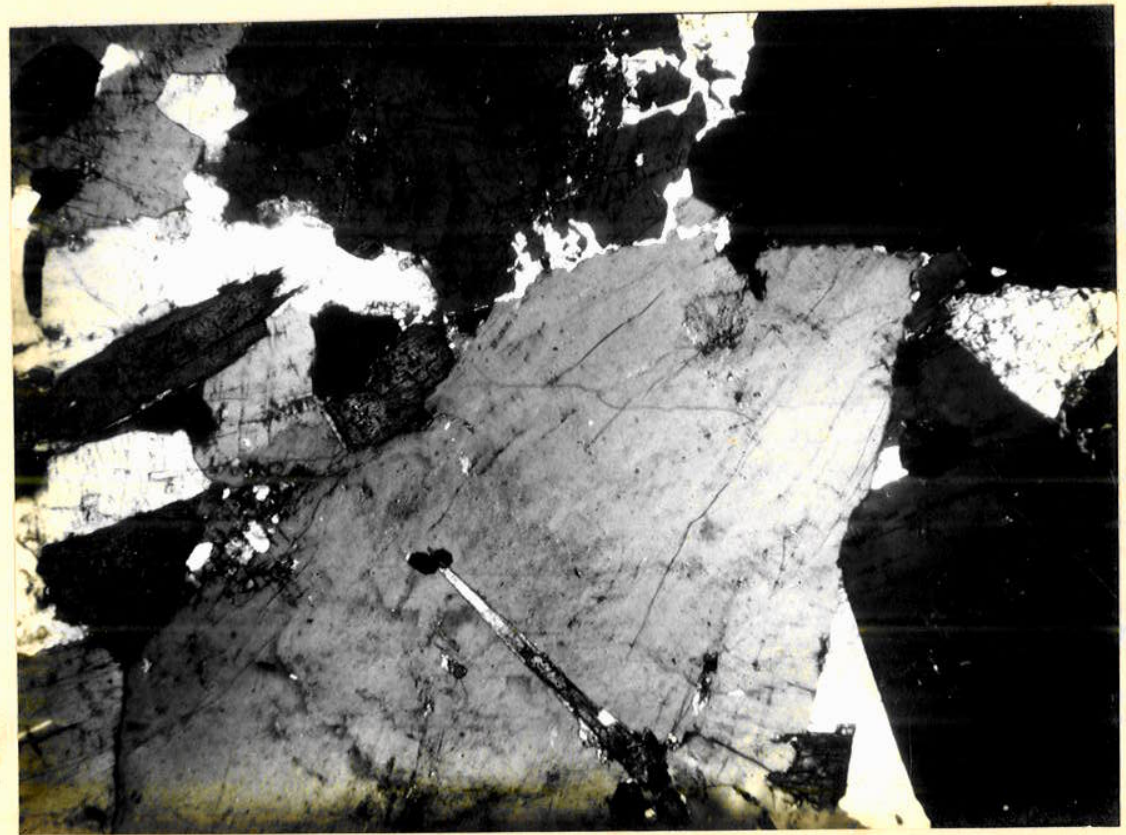

Fotomicrografia 14 - Pulaskito. Cristais de feldspato alca lino(cinza médio a escuro)associados à nefelina(cinza es-curo, parte inferior da foto), cancrinita(branca, formandose às expensas da nefelina)e egirina-augita(cinza escuro, minerais prismáticos zonados mostrando clivagem). Nícois cruzados. Aumento: $20 \mathrm{X}$. 


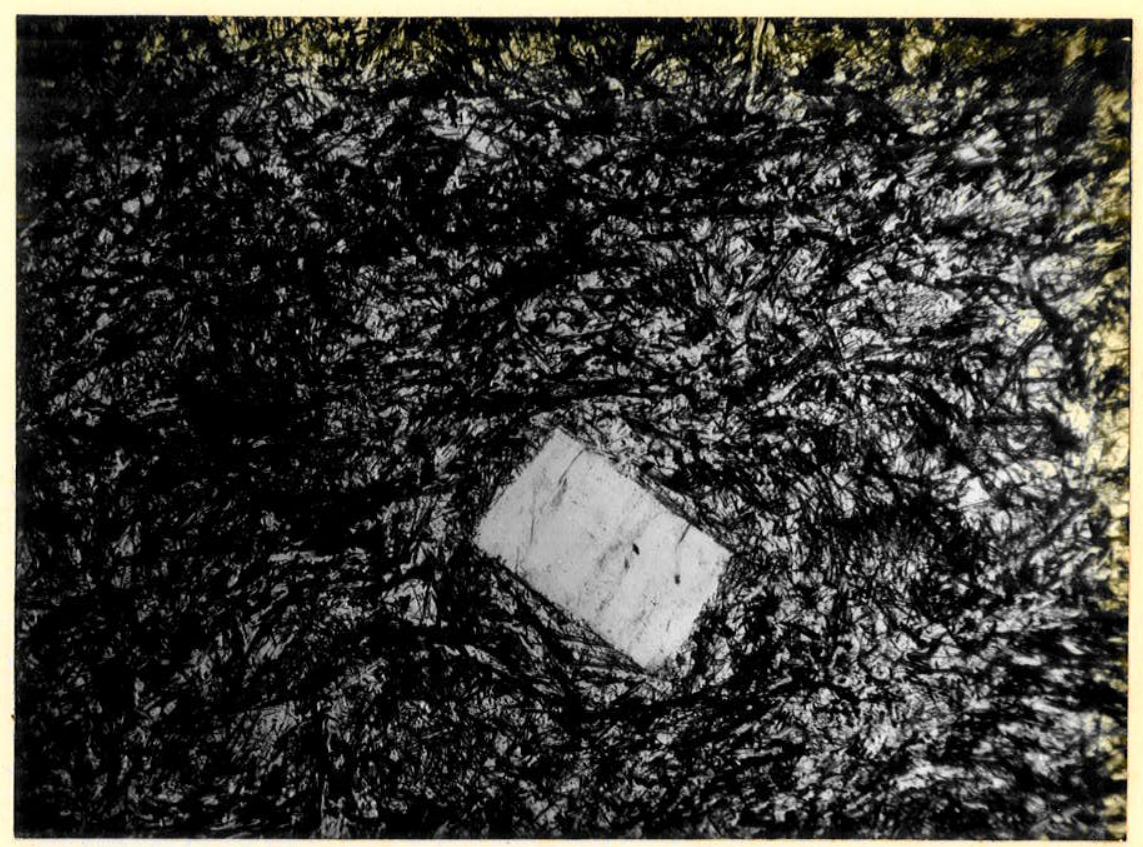

Fotomicrografia 15 - Tinguaíto. Textura tinguaítica.Cris tais aciculares de piroxênio dispersos caòticamente e associados a material de côr branca e composto de can crinita e feldspato alcalino. Vê-se também um fenocristal de nefelina mostrando contornos regulares. Nícois paralelos. Aumento: $20 \mathrm{X}$.

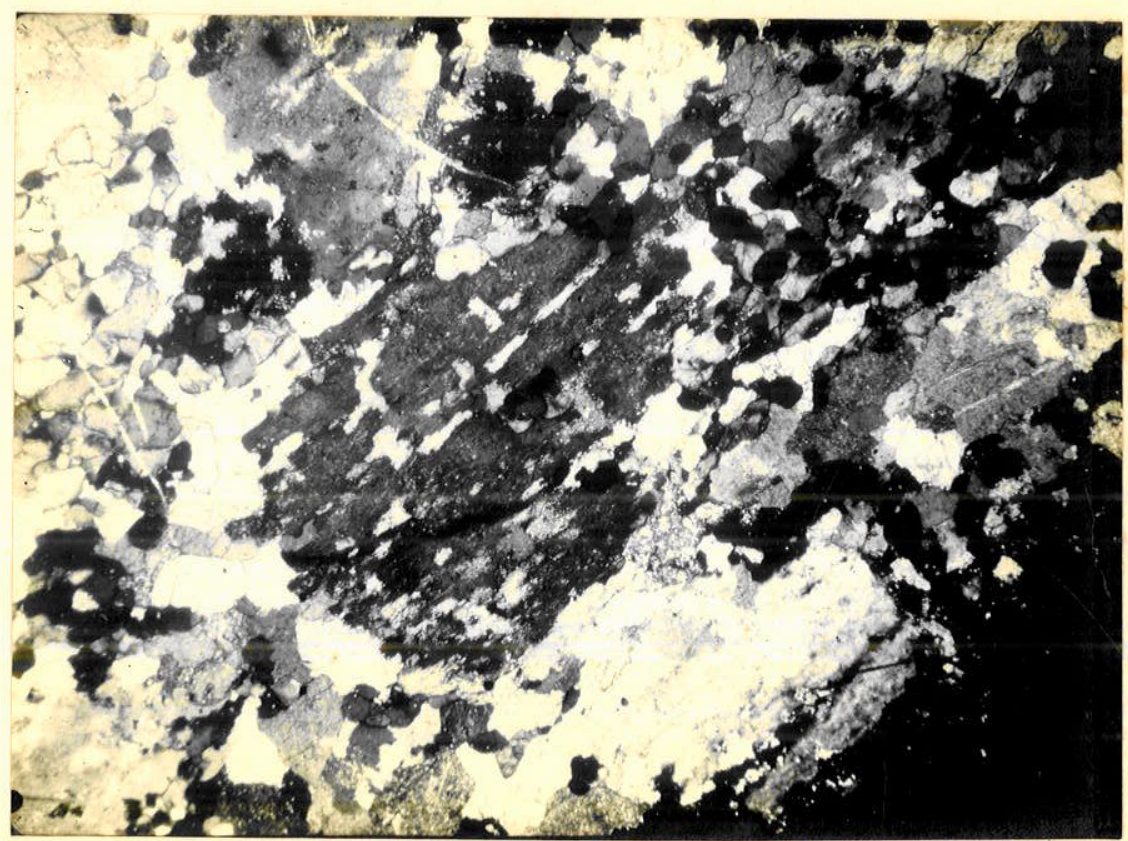

Fotomicrografia 16 - Carbonatito. Cristal de feldspato al calino(cinza escuro) sendo substituído por calcita(branca a cinza claro e relêvo variável) nas suas partes marginais e ao longo das linhas de clivagem. Vêem-se também cristais equidimensionais de apatita (cinza escuro e relêvo al.to). Nícois cruzados. Aumento: $20 \mathrm{X}$. 


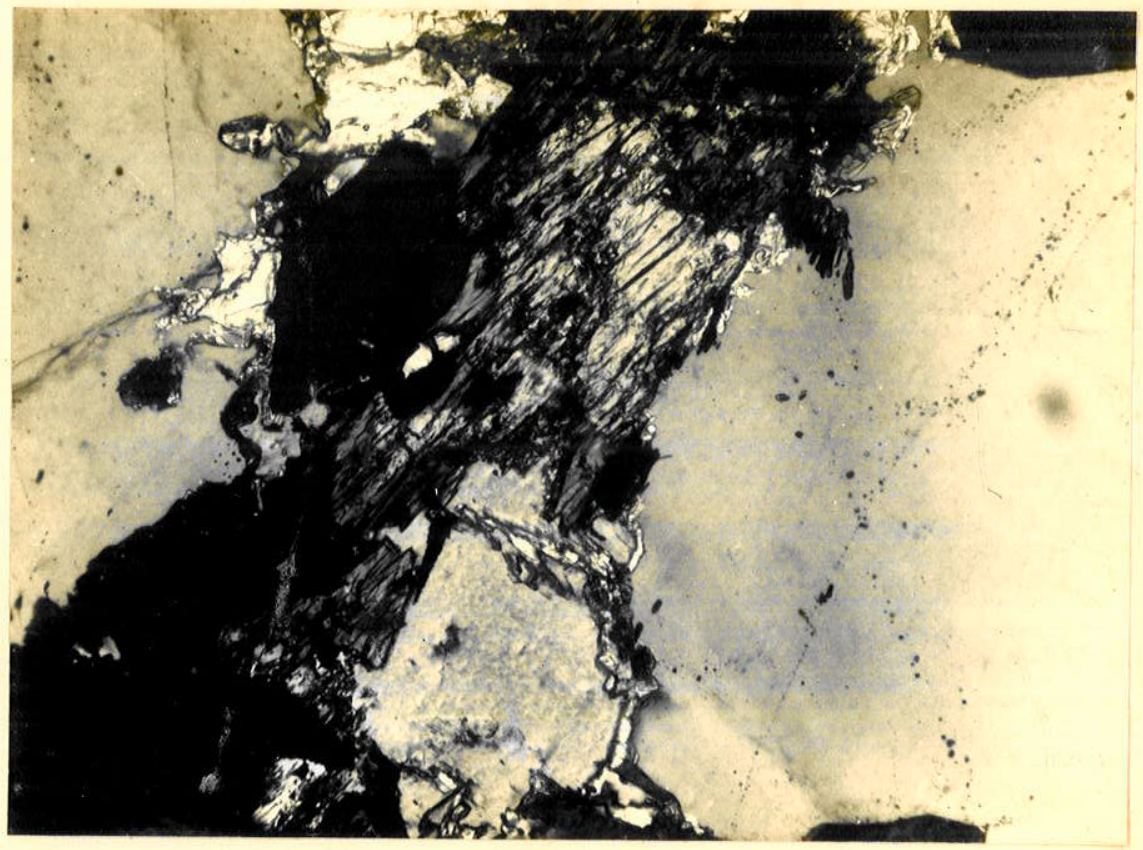

Fotomicrografia 17 - Cristal de hornblenda com clivagem (cinza claro)sendo substituído nas suas partes marginais por riebeckita(cinza escuro). Ao lado aparecem quartzo e feldspato alcalino(cinza claro)e cristais de calcita(cinza médio com relêvo variável). Nícois cruzados. Aumento:

$\mathrm{X}$.

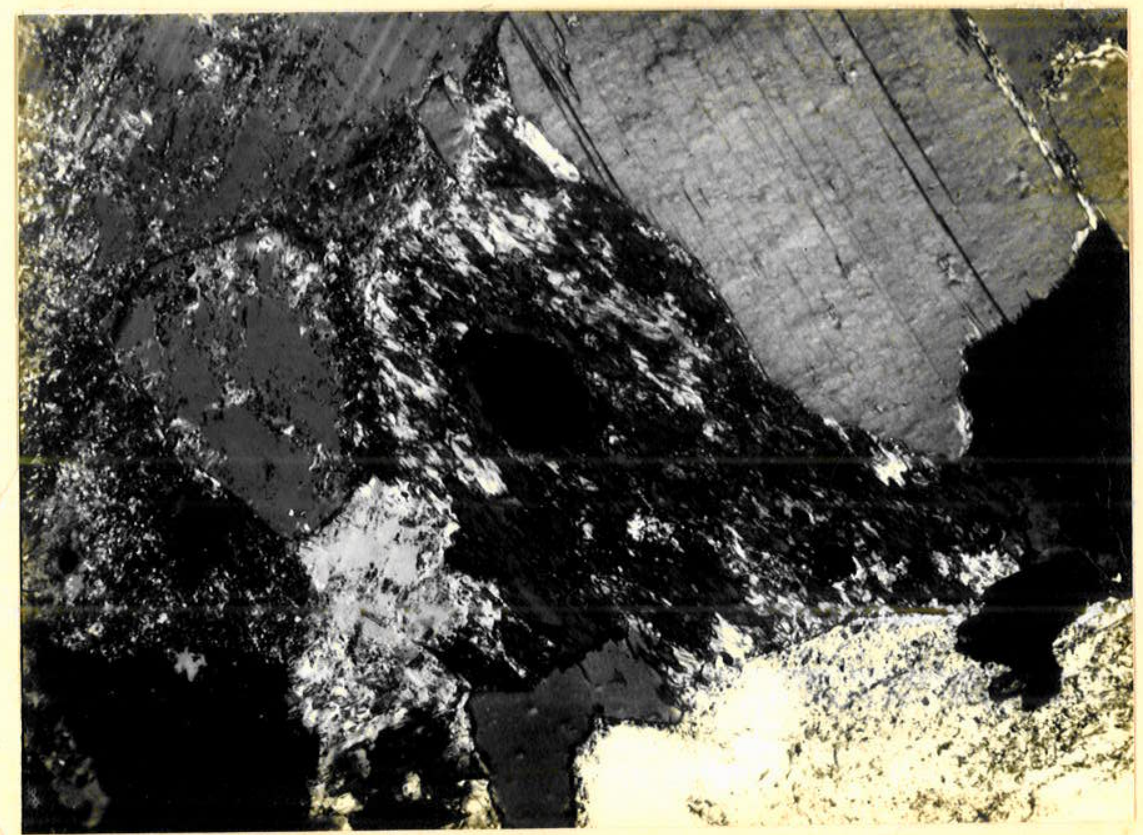

Fotomicrografia 18 - Cr stal de riebeckita (cinza escuro) fcrmando-se às expensas de biotita (branca e cinza cla r()). Ao lado aparece um outro cristal de biotita, porém. ir alterado. Nícois cruzados. Aumento: 